VILNIAUS GEDIMINO TECHNIKOS UNIVERSITETAS

Stasys DAILYDKA

\title{
KELEIVIŲ VEŽIMO GELEŽINKELIU PRIEMONIŲ PARINKIMO TYRIMAS
}

\section{DAKTARO DISERTACIJA}

TECHNOLOGIJOS MOKSLAI, TRANSPORTO INŽINERIJA (03T) 
Disertacija rengta 2007-2011 metais Vilniaus Gedimino technikos universitete.

\section{Mokslinis vadovas}

prof. habil. dr. Leonas Povilas LINGAITIS (Vilniaus Gedimino technikos universitetas, technologijos mokslai, transporto inžinerija - 03T).

VGTU leidyklos TECHNIKA 1876-M mokslo literatūros knyga http://leidykla.vgtu.lt

ISBN 978-9955-28-851-0

(C) VGTU leidykla TECHNIKA, 2011

(C) Stasys, Dailydka, 2011

s.dailydka@litrail.lt 
VILNIUS GEDIMINAS TECHNICAL UNIVERSITY

Stasys DAILYDKA

\section{A STUDY ON THE OPTIONS OF MEANS FOR RAILWAY PASSENGER TRANSPORTATION}

DOCTORAL DISSERTATION

TECHNOLOGICAL SCIENCES,

TRANSPORT ENGINEERING (03T)

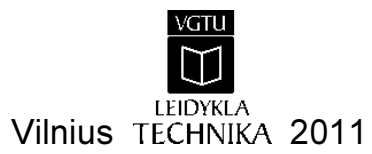


Doctoral dissertation was prepared at Vilnius Gediminas Technical University in 2007-2011.

\section{Scientific Supervisor}

Prof Dr Habil Leonas Povilas LINGAITIS (Vilnius Gediminas Technical University, Technological Sciences, Transport Engineering - 03T). 


\section{Reziumè}

Disertacijoje nagrinejjami būdai, metodai ir priemonès, kurie leistų maksimaliai sumažinti nuostolius, patiriamus vežant keleivius vietiniais geležinkelių maršrutais. Pastaruoju metu dèl objektyvių priežasčiu gerokai sumažějo keleivių, dèl to krinta pajamos, o nuostoliai dideja. Todèl darbe pateikiamos kompleksinès priemonès nuostoliams šioje srityje mažinti. Sudarytas traukinių formavimo matematinis modelis leidžia optimizuoti kiekvieno maršruto sąstatus ir traukos rūši o pateiktos keleivių komforto gerinimo sąlygos suteiks galimybę daugiau keleivių pasirinkti geležinkelių transporta, o kartu padidinti keleivių vežimo sektoriaus pajamas.

Pirmajame skyriuje išanalizuoti pastarujų metų moksliniai darbai, susiję su keleivių vežimo geriausių sąlygu paieška tiek organizaciniu, tiek komforto gerinimo požiūriais.

Antrajame skyriuje analizuojama esama padètis Lietuvos geležinkelių sistemoje pagal atskirus maršrutus, išryškinamos keleivių vežimo sektoriaus problemos bei perspektyviniai uždaviniai, keleivių parko būklè, investicijų poreikis.

Trečiajame skyriuje sudarytas matematinis modelis racionaliems traukinių sąstatams parinkti atsižvelgiant i dinamiką bei galimą traukos rūšį. Modelio reikšmingumas parodytas keliuose būdinguose ruožuose, kuriuose keleivių dinamika skirtinga ir gali būti panaudota įvairiarūšè trauka.

Ketvirtajame skyriuje analizuojamos ịvairios priemonès keleivių komfortui gerinti. Pagrindinè jų - žmogaus sveikatai žalingos vagonų vibracijos poveikio mažinimas. Sudaryta tikslo funkcija, leidžianti parinkti optimalius dinaminius vagonų vežimèlių pakabų koeficientus, lemiančius vagonų vibracijas esant ịvairiems greičiams ir kelio sužadinimams (nelygumams).

Disertacijos pabaigoje pateikiamos išvados ir rezultatų apibendrinimas.

Disertacijos tema autorius paskelbė septynis mokslinius straipsnius: keturi straipsniai - ISI Web of Science mokslo žurnaluose, du straipsniai - recenzuojamuose mokslo žurnaluose, vienas straipsnis - recenzuojamame tarptautinès konferencijos straipsnių rinkinyje. S. Dailydka yra vienas iš vadovèlio „Traukos riedmenų elektros pavaros ir jų valdymas" bendraautorių. 


\section{Abstract}

This thesis investigates means, methods and instruments enabling to decrease losses in relation to passenger transportation by railways at local routes. During the recent time, due to objective reasons, the number of passengers decreased substantially due to the decreasing income of people, and losses of the railways are increasing.

The thesis presents complex means for minimizing of the loses in this areas. Train set formation mathematical model enables to optimise train sets and traction type for each route, and the analysis of passenger comfort improvement conditions should ensure the feasibility to attract more passengers to chose railway transportation, and at the same time - to increase income level in the sector of passenger transportation.

The first chapter analyses research works of the recent years related to the search of the best conditions for passenger transportation both on the organizational side, and on the side of passenger comfort improvements.

The second chapter analyses the present situation in the railway system of Lithuania on the basis of specified routes, problems are identified in the passenger transportation sector, together with the tasks for the future, passenger inventory condition and investment needs are defined.

The third chapter is devoted for making up of a mathematic model for rational solutions of train sets on the basis of passenger number dynamics and traction types. The significance of the model is shown for certain characteristic sectors with fluctuating passenger number dynamics where multiple traction options can be used.

The fourth chapter analyses various means for passenger comfort improvement. One of the most important aspects - decreasing of vibrations in carriages which are harmful to human health. Target function was made up which provides the enables the selection of carriage (undertrack) suspension optical dynamic coefficients in relation to carriage vibrations at various speeds and track irregularities.

The thesis ends with conclusions and summary of the results.

The author of this thesis published 7 research (scientific) articles: 4 articles at ISI WEB of Science magazines; 2 articles - at research review magazines in English, German, and French languages; 1 article - at reviewed materials of an international conference held in Lithuania. S. Dailydka is one of the co-authors of study books "Traukos riedmenų elektros pavaros ir jų valdymas" (Traction Rolling-Stock Electric Drives and their Operation). 


\section{Turinys}

IVADAS ...

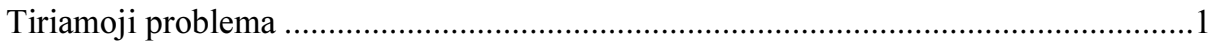

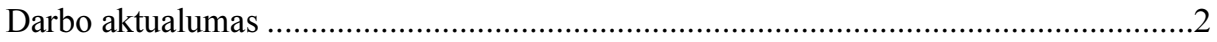

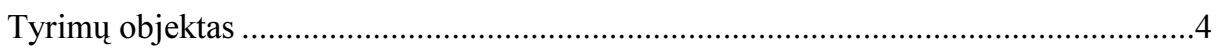

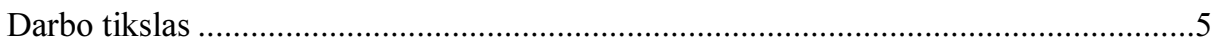

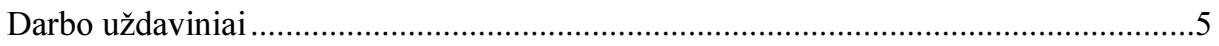

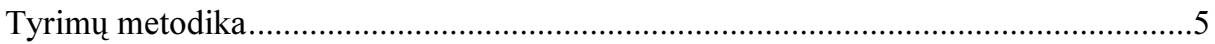

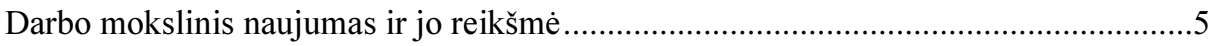

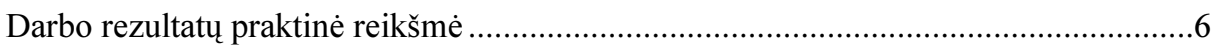

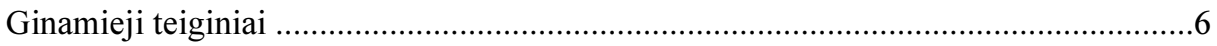

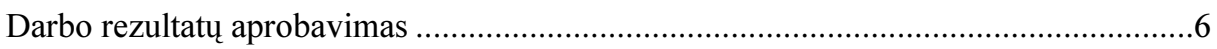

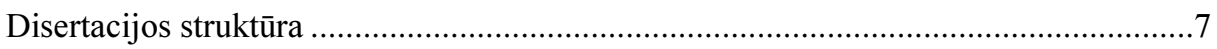

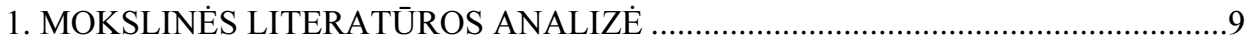

1.1. Darbai, nagrinèjantys keleivių vežimo organizavimą ..........................................9

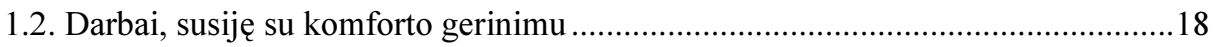

1.3. Pirmojo skyriaus išvados ir disertacijos uždavinių formulavimas ........................21 


\section{KELEIVIŲ VEŽIMO GELEŽINKELIAIS ESAMOS PADĖTIES}

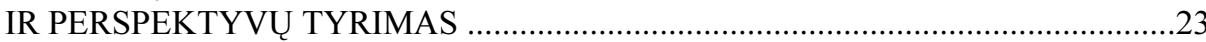

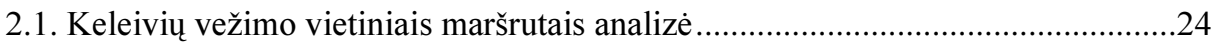

2.2. Pagrindinès problemos keleivių vežimo sektoriuje..............................................30

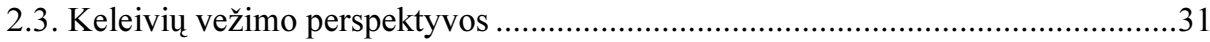

2.4. Pagrindiniai uždaviniai, keliami keleivių vežimo sektoriui ..................................33

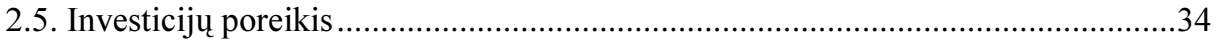

2.6. Keleivių vežimas Lietuvoje pagal atskiras transporto rūšis ...................................35

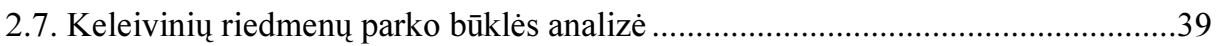

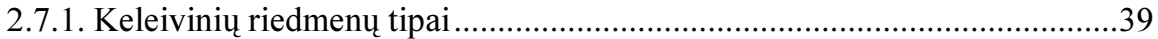

2.7.2. Keleivinių lokomotyvų skaičiaus pasiskirstymas

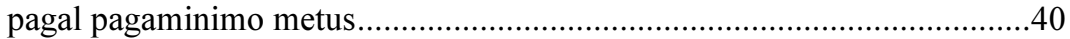

2.7.3. Keleivinių vagonų parko bendroji analizè...................................................4

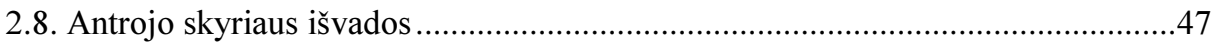

3. MATEMATINIO MODELIO SUDARYMAS IR TAIKYMAS PRIEMONĖMS

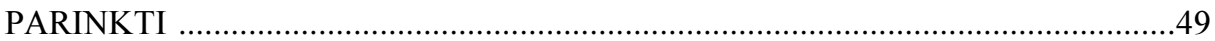

3.1. Racionalių keleivinių sąstatų parinkimo privalumai ............................................49

3.2. Keleivių srautai pagal ruožus ir vežimo priemonių parinkimo modelis................51

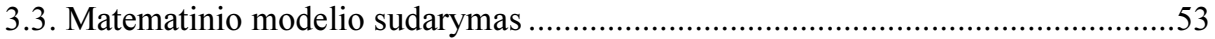

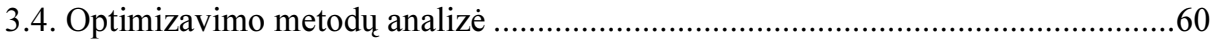

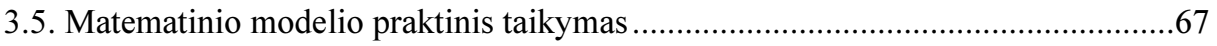

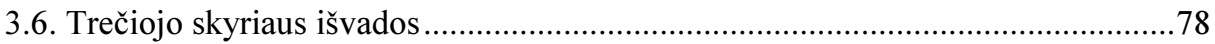

4. KOMFORTO GERINIMO KELEIVINIUOSE TRAUKINIUOSE VEIKSNIAI $\quad . . . .81$

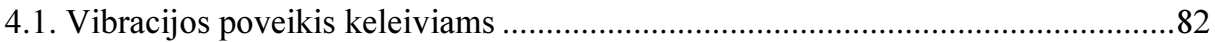

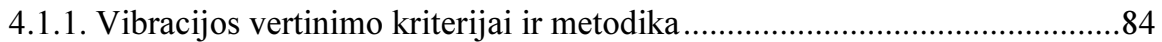

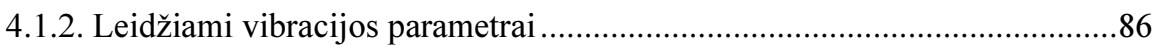

4.2. Keleivinių vagonų važiuoklių pakabų optimalių parametrų

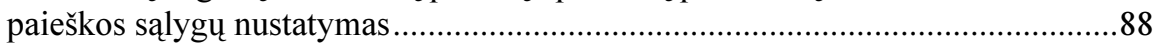

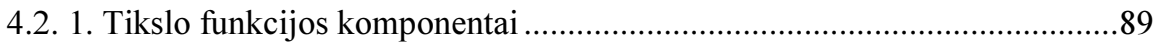

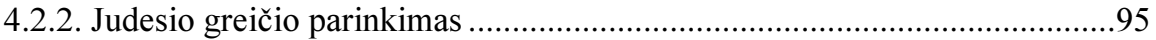

4.2.3. Optimalių vežimèlio pakabos parametrų parinkimas ..................................100

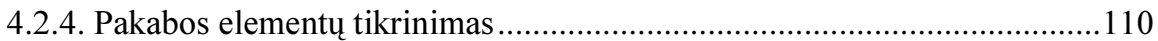

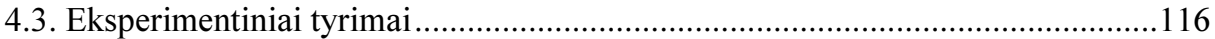

4.4. Darbe taikomų priemonių vežimo nuostolių mažinimo galimybès.....................120

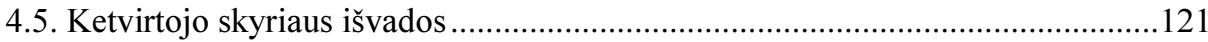




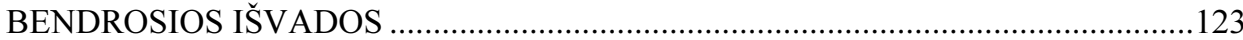

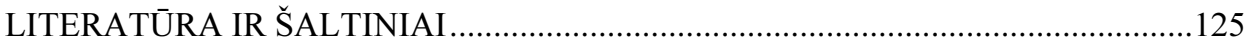

AUTORIAUS PUBLIKACIJŲ DISERTACIJOS TEMA SĄRAŠAS ............................133

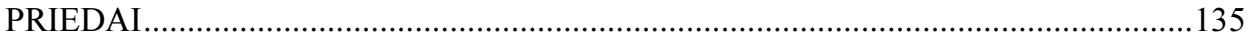

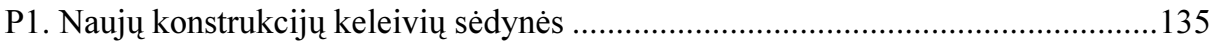

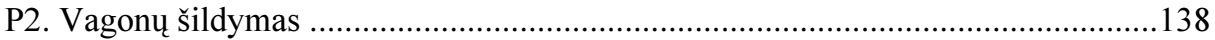

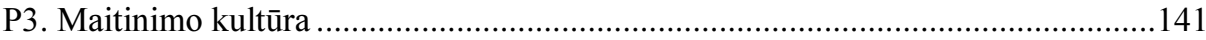

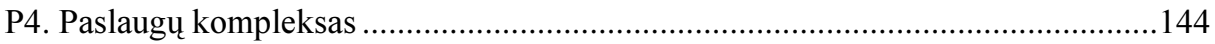

P5. Priemonių parinkimo modelio sprendinių paieškos

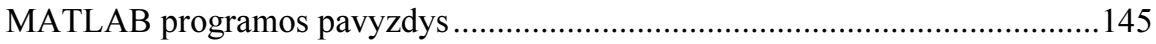

P6. Ašidèžių pakabos parametrų patikrinamujų rezultatų skaičiavimai.....................146 



\section{Table of Contents}

INTRODUCTION

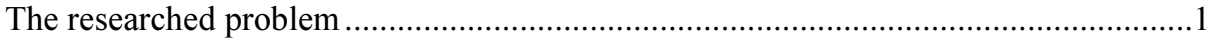

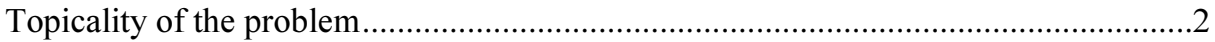

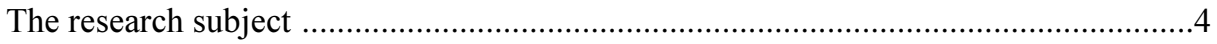

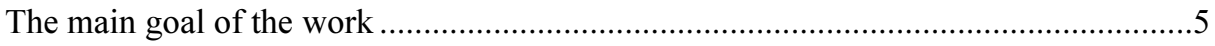

Tasks of the work

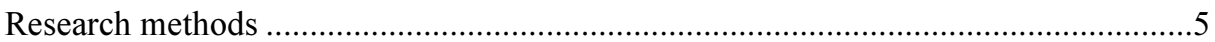

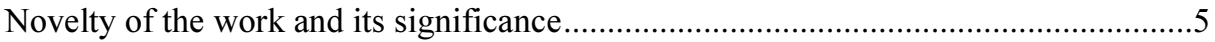

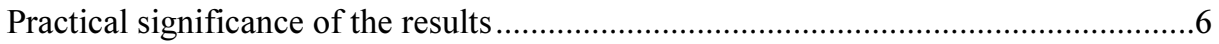

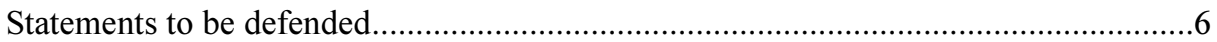

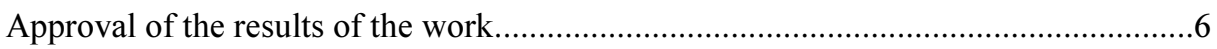

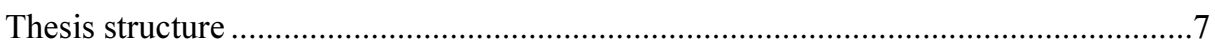

1. ANALYSIS OF THE RESEARCH LITERATURE ................................................

1.1. Works investigating the organizational aspects of passenger transportation ..........9

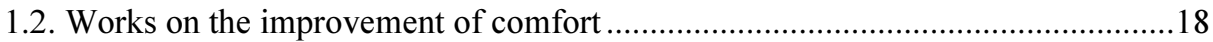

1.3. Conclusions of the first chapter and formulations of thesis tasks ........................21 
2. RESEARCH OF THE EXISTING SITUATION OF RAILWAY PASSENGER

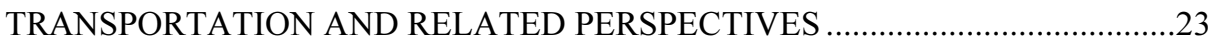

2.1. Analysis of passenger transportation at local routes ...........................................24

2.2. Main problems of the passenger transportation sector ..........................................30

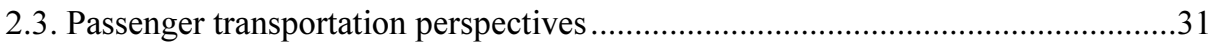

2.4. Basic tasks raised for the passenger transportation sector....................................33

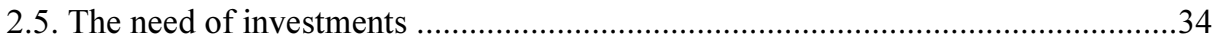

2.6. Passenger transportation flows in Lithuania per transport types ............................35

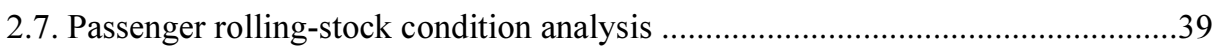

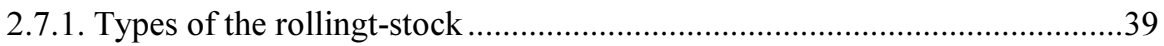

2.7.2. Allocation of passenger locomotive numers based

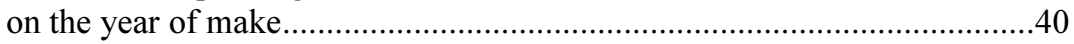

2.7.3. General analysis of passenger carriages stock ..................................................

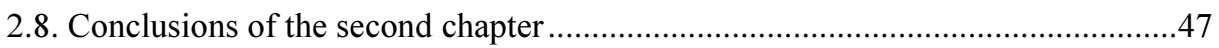

3. MAKING UP OF A MATHEMATICAL MODEL FOR THE SELETION OF MEANS AND ITS APPLICATION …………..........................49

3.1. Benefits for the selection of rational passenger railway sets...............................49

3.2. Passenger flows per routes and transportation means selection model ..................51

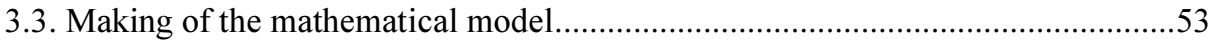

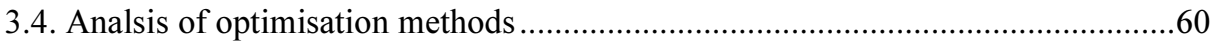

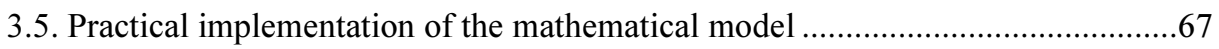

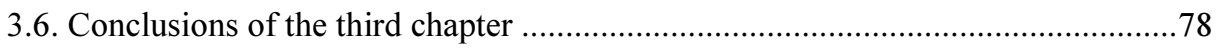

4. COMFORT IMPROVEMENT FACTORS AT PASSENGER TRAINS .....................81

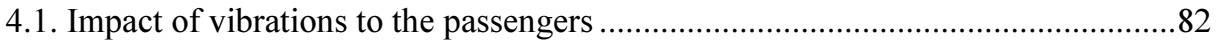

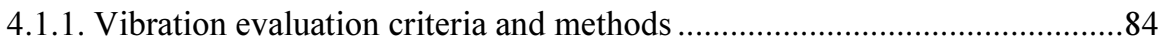

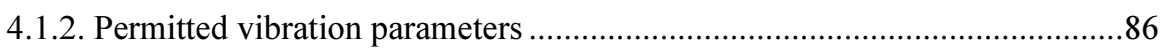

4.2. Defining of optimal parameters search conditions

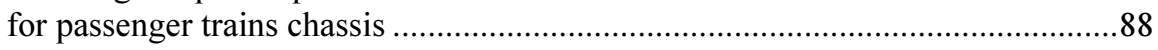

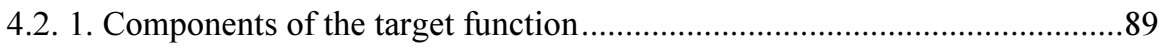

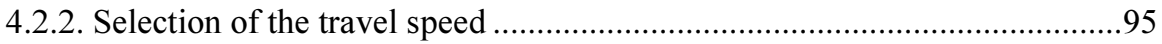

4.2.3. Selection of optimal parameters of undercarriage suspension ....................100

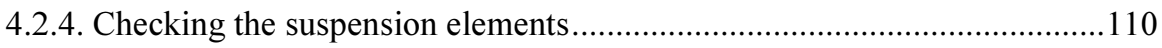

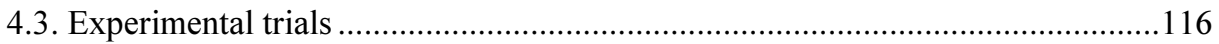

4.4. Means for decreasing of the transportation losses applied at work ....................120

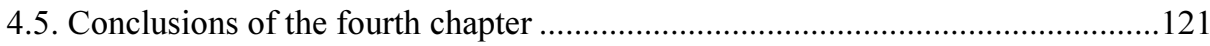




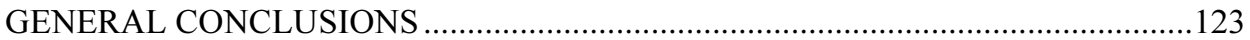

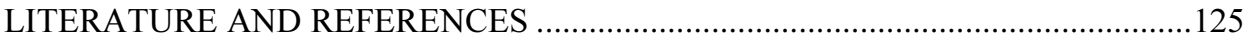

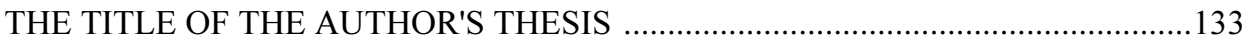

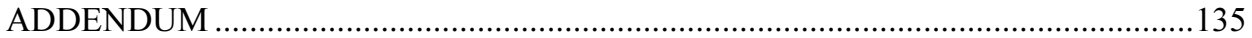

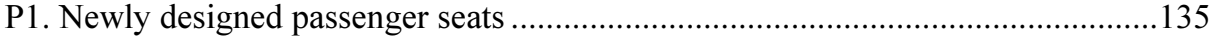

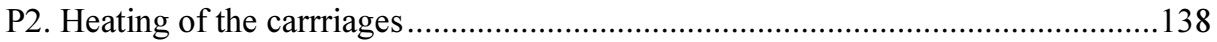

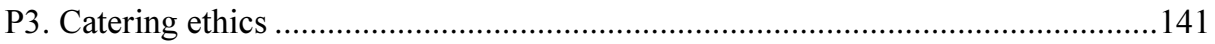

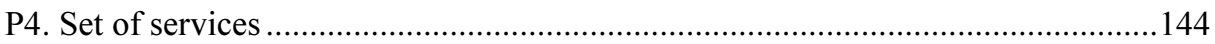

P5. An example of means selection model solution search software matlab .............145

P6. The verification results of calculation of axle suspension parametres ................146 



\section{Ivadas}

\section{Tiriamoji problema}

Spartus socialinis ekonominis Europos Sajungos šalių vystymasis, technikos raida, pasaulinès prekybos globalizacijos tendencijos sukelia didžiuli aukštos kokybès transporto paslaugų poreiki. Šiuo metu egzistuojanti transporto paslaugu sistema, kurios pagrindas yra kelių transportas, jau negali tenkinti tendencingai augančių vartotojų transportinių poreikių. Vakarų Europos šalys, siekdamos užtikrinti sauga, ekologinę situaciją bei taupyti energinius ir kitus išteklius, ekonominèmis ir teisinèmis priemonėmis skatina keleivių vežimą geležinkeliu, o Lietuvoje taikomos vienodos lengvatos keliauti visuomeniniu automobilių kelių ir geležinkeliu transportu. Nuolatos didejantis individualių transporto priemoniu skaičius, kelių transporto infrastruktūros plètros ribotos galimybès, auganti transporto paklausa sukelia globalinių transporto problemų.

Geležinkelio transportas yra saugesnis, kur kas mažiau žalingas aplinkai, daug našesnis nei automobilių transportas, bet reikalaujantis didžiulių geležinkelio infrastruktūros investicijų, todèl geležinkelio transportas Europoje visų pirma remiamas finansiškai, suteikiant geležinkeliams paskolas lengvatinèmis sąlygomis, dengiant jų nuostolius dèl nuostolingos visuomeninès veiklos. Vakarų Europos šalyse didesnis dèmesys skiriamas keleivių vežimui geležinkeliu ir yra 
labiau orientuotas i mažesnes pajamas gaunančius gyventojus nesiekiant iš šios veiklos pelno.

Būtina atsižvelgti i šalies gyventojų poreikių tenkinimą ekonominiu, socialiniu, aplinkos ir keleivių apsaugos požiūriu, užtikrinti ES principus dèl laisvo prekių ir žmonių judèjimo.

Esamo AB „Lietuvos geležinkeliai“ keleivinio riedmenų parko techninès galimybès artejja prie kritinès ribos - vidutinis parko amžius siekia 24 metus, kai daugumos keleivinių riedmenų resursas - 28 metai, vežamų geležinkelio transportu keleivių mažeja, o kartu mažèja ir pajamos.

Ilgalaikejje Lietuvos transporto sistemos plètros strategijoje ir geležinkelių transporto sektoriaus reformos istatyme numatytiems tikslams igyvendinti neskiriama būtinų lèšuc todèl keleivių vežimo geležinkelių transportu perspektyva Lietuvoje nèra apibrèžta. Lietuvos Respublikos geležinkelių transporto kodekse (Lietuvos Respublikos geležinkelių transporto kodeksas... 2004) įtvirtinta nuostata dèl nuostolių, patirtų prisièmus nuostolingą visuomenès aptarnavimo i̇sipareigojimą, kompensavimo, tačiau asignavimų valdytoja LR susisiekimo ministerija iš valstybès biudžeto skiria lèšas, kurios dengia labai nedidelę keleivių vežimo nuostolių dali (per pastaruosius ketverius metus vidutiniškai buvo dengiama tik 8 proc. nuostoliu). $\mathrm{AB}$ „Lietuvos geležinkeliai“ patiriamus nuostolius dengia iš pajamų gaunamų iš krovinių vežimo. Kadangi valstybès institucijos kol kas nepajègios kompensuoti visus nuostolius, patiriamus vežant keleivius, būtina ieškoti racionaliausių būdų, kaip padidinti pajamas ir sumažinti nuostolius šioje srityje. Šis disertacinis darbas kaip tik ir skiriamas minètiems uždaviniams spręsti.

Pagrindiniai spręstini uždaviniai yra šie: kiekvienam maršrutui parinkti racionaliausias transporto priemones bei jų sąstatus, ịvertinus keleivių skaičiaus dinamiką ruožuose, atstumus, maksimizuojant pajamas ir minimizuojant išlaidas; didinti traukiniais važiuojančių keleivių skaičių pažangiomis organizacinèmis (maršrutų traukinių dažniai) ir techninèmis (vibracijų mažinimas vagonuose, klimato sąlygų gerinimas, ergonomika) priemonėmis.

\section{Darbo aktualumas}

Mokslinejje literatūroje stokojama pagrịstų sprendinių kuriais remiantis galima kompleksiškai ịvertinti keleivių vežimo geležinkeliais pajamų didinimo ir išlaidų mažinimo galimybes.

Mokslinė problema - ištirti bei moksliškai pagrịsti keleivių vežimo geležinkeliais pajamų ir išlaidų priklausomybę nuo riedmenų derinių, techninių charakteristikų, traukos rūšies, kad galima būtų nustatyti pačius racionaliausius priemonių parinkimo variantus konkretiems keleivių vežimo maršrutams, mak- 
simaliai gerinti komfortą siekiant pritraukti kuo daugiau keleivių naudotis geležinkelių transportu ir mažinti iš šios veiklos patiriamus nuostolius.

Mokslinès problemos ištyrimo lygis. Keleivių vežimą geležinkeliu tiek mūsų šalyje, tiek pasaulyje vienu ar kitu aspektu nagrinejja daugelis mokslininkų: Butkevičius, J.; Sivilevičius, H.; Podvezko, V.; Wang, H.; Cui, Y.; Li, B.; Yiying, Zhang; Qiyuan, Peng; Siyu Tao; Weixiong Zha; Chaozhe Jiang; Bao, J.; Xin, L.; Tang, Z.; Zang, X.; Budai, G.; Maróti, G.; Dekker, R.; Huisman, D.; Kroon, L.; Li, K. P.; Gao, Z. Y.; Mao, B. H.; Cao, C.; Kuznecova, N. V.; Morozova, M. V.; Lisenko, O. A.; Celebi, D.; Bolat, B.; Bayraktar, D.; Sahin, B.; Yilmaz, H.; Ust, Y.; Guneri, A.F.; Gulsun, B.; Bažant, M.; Kavička, A.; Shrivastava, P.; O'Mahony, M.; Kasturia, S.; Verma, A. ir kt. Mūsų šalies autoriai dažniausiai atliko ekspertinius tyrimus, išryškindami keleivių pageidavimus, nustatydami atskirų ruožų apkrova, gvildendami keleivių vežimo nuostolingumo klausimus, konkurencingumo su automobilių transportu sąlygas bei „Rail Baltica" projekto galimybes.

Rytų šalių, kuriose yra dideli keleivių srautai, autoriai dažniausiai nagrinejja eismo programavimo vežti keleivius ilgais atstumais klausimus. Keliamos tokios problemos, kaip keleivių persodinimas, traukinių jungčių skaičius, nagrinejjama ekonominé nauda ir nuostolingi keleivinių traukinių srautai, vèlavimo problemos.

Kai kurie autoriai (Manoj, Schonfeld, Sutapa 2007) nagrinejja išlaidų mažinimo klausimus tiesiant naujas tranzitinių traukinių linijas.

Gvildenama labai svarbi geležinkelio riedmenų pusiausvyros atkūrimo problema, kai dèl kintančiu aplinkybių būtina keisti tvarkaraščius (Budai, Maróti, Dekker, Huisman, Kroon 2010).

Kai kurie autoriai (Morozova 2009; Lisenko 2006) keleivių išlaidų mažinimą sieja su keleivinių riedmenų eksploatacinių rodiklių gerinimu, taupant léšas traukai, remontui, personalo skaičiaus mažinimui diegiant naujas technologijas ir pan.

Nagrinėjami klausimai, kai parenkamos dvi ar daugiau transporto rūšys, pvz., traukinys ir autobusas. Tai leidžia išvengti spūsties keliuose ir racionaliai naudoti vežimo priemones. Autoriai Shrivastava, P. ir O'Mahony, M. (2009) tiria privažiuojamujuc kelių maršrutus ir koordinuotus tvarkaraščius pasirinktose geležinkelio stotyse.

Apžvelgtos pasaulinès mokslinès tendencijos, ieškant racionalių keleivių vežimo metodu, rodo, kad pagrindinis demesys skiriamas problemoms, kurias sukelia dideli keleivių srautai ir ilgi atstumai. Tačiau praktiškai nèra pasaulinio masto darbų keleivių vežimo organizavimo klausimais, kai keleivių srautai ir atstumai nėra dideli, kas būdinga Lietuvos sąlygomis, t. y. dèl mažo keleivių skaičiaus pajamos staigiai mažèja, o sąnaudos mažèja labai nedaug. 
Taigi labai svarbus aspektas - pritraukti kuo daugiau keleivių i geležinkelių transportą. Tai pasiekiama ne tik organizacinèmis, bet ir techninèmis priemonèmis gerinant komforta vagonuose. Čia pagrindinis veiksnys - vibracijų mažinimas. Šiuo klausimu pasaulyje dirba daug autorių, iš kurių paminèti šie: Rekleitis, G.; Reivindran, A.; Regsdel, K.; Michailičenko, G. S.; Kovalev, R. V.; Polak, E.; Bestle, D.; Eberhard, P.; Kalker, J.; Schiehlen, W.; Erikson, P.; Arora, J. S.; Snyman, J. A.; Jones, D. R.; Perttunen, C. D. ; Stuckman, B. E.; Jefimova, G. N.; Keršys, R.; Bazaras, Ž.; Lingaitis, L. P.; Dailydka, S.; Myamlin, S.; Prichodko, V.; Morozov, N. I.; Žižko, V. V.; Lazarian, V. A.; Korotenko, M. L.; Uškalov, V. F.; Danovič, V. D.; Nikolajev, V. A.; Sokolov, M. M.; Varava, V. G.; Levit, G. M.; Manaškin, L.A.; Veršinskij, S. V.; Danolov, V. N.; Chusidov, V. D.; Reznikov, L. M.; Redko, S. F.; Kamajev, V. A.; Kozlov, M. P. ir daugeli kitų. Visi jie nagrinèjo vagonu vibracijos klausimus, nustatinèdami važiuoklių pakabų parametrus priklausomai nuo kelio sužadinimo funkcijos.

Tam taikomi ịvairūs kompiuterinès realizacijos optimizavimo metodai. Atlikta programavimo algoritmų analize leidžia išskirti Huko-Dživso, Neldelio-Mido, Devidono, Fletčerio, Pauelo metodus. Pastarasis dažniausiai ir taikomas.

Sprendžiant globalius optimizacijos uždavinius tinkami ir kiti metodai. Juos galima suskirstyti $\mathfrak{i}$ tokias grupes: 1) metodai, kurių pagrindą sudaro lokalinės paieškos metodai; 2) tiesioginiai globalinès paieškos metodai (genetiniai algoritmai, imitacijos metodas, DIRECT metodas); 3) metodai, naudojantys paviršiaus atspindžio aproksimaciją ir (arba) skaičiavimo schemas.

Taigi išanalizavus mokslinę literatūrą šiuo klausimu matyti, kad pasaulyje atlikta gana daug darbų sprendžiant virpesių klausimus pačioje pakaboje. Tačiau nèra darbų, kuriuose sprendžiamas vientisas uždavinys (kelias, pakaba, vagonas) esant ịvairiems vagono greičiams. Todèl šios darbo dalies siekis yra:

1. Sudaryti tikslo funkciją iš pakabos bedimensių dinamikos koeficientu, lemiančių pakabos kokybę.

2. Parinkti optimalią šių koeficientų visumą esant ịvairiems greičiams.

3. Sudaryti optimizuotu pakabos elementu atsparumo skaičiavimo algoritmą.

\section{Tyrimų objektas}

Tyrimų objektas - keleivių vežimo geležinkelių transportu priemonės. Pagrindinis dèmesys kreipiamas į keleivinių traukinių maršrutų ir naudojamų priemonių techninių charakteristikų analizę, parenkant riedmenų derinius konkretiems maršrutams pagal keleivių skaičių ir racionaliausią trauką bei gerinant keleivių komfortą. 


\section{Darbo tikslas}

Parengti kompleksinius teorinius ir praktinius sprendinius, skirtus didinti pajamas bei mažinti patiriamus nuostolius iš keleivių vežimo geležinkeliais, įvertinus technologinius konkrečių ruožų poreikius bei dinamiškai kintančius keleivių srautus, gerinti keleivių komfortą ir pritraukti kuo daugiau keleivių i geležinkelių transporta.

\section{Darbo uždaviniai}

1. Išanalizuoti pasaulinèje mokslinèje literatūroje su keleivių vežimu geležinkeliais susijusias problemas ir jų sprendimo būdus.

2. Ištirti susidariusią padèti keleivių vežimo geležinkeliais sektoriuje, nustatyti jo reikšmę šalies ūkiui.

3. Nustatyti keleivių vežimo geležinkeliais pajamų ir išlaidų komponentes bei identifikuoti jų priklausomybę nuo techninių riedmenų parametrų.

4. Sudaryti keleivių vežimo geležinkeliais racionalių priemonių parinkimo matematinį modeli.

5. Modeliui taikant netiesinių lygčių su daugeliu kintamujų ir apribojimais ekstremumo paieškos metodą, parinkti riedmenis konkretiems maršrutams keleivių vežimo Lietuvos geležinkeliais pavyzdžiu.

6. Parengti riedmenų komforto charakteristikų gerinimo rekomendacijas mažinti vagonų vibracijas, parenkant racionalius parametrus vežimèlių pakaboms, esant ịvairiems greičiams.

\section{Tyrimų metodika}

Darbe taikyti regresinès analizès, matematinio modeliavimo, globalios optimizacijos metodai.

\section{Darbo mokslinis naujumas ir jo reikšmè}

Sukurtas modelis minimizuoti keleivių vežimo geležinkeliu nuostolius, ịvertinant maršrutų keleivių skaičiaus kitimo dinamiką naudojamas traukos rūšis ir visas pajamų ir išlaidų sudedamąsias dalis. Optimizavus tikslo funkcija, pateikiami racionaliausi konkretaus maršruto traukinių variantai. 
Sudaryta tikslo funkcija racionaliems keleivinių vagonų vežimèlių pakabų parametrams nustatyti ir sumažinti vagonų virpesius iki minimumo, siekiant pagerinti traukinio tolygios eigos rodiklius $W$.

\section{Darbo rezultatų praktinė reikšmè}

Darbo rezultatai suteikia galimybę naudoti ekonomiškiausias maršrutų traukos rūšis ir traukinius, optimizuoti keleivinių riedmenu parką issigyjant naujus riedmenis, nustatyti reikalavimus keleivių komfortui. Tai leis pritraukti daugiau keleivių ir mažinti bendrąsias keleivių vežimo geležinkeliais sąnaudas.

\section{Ginamieji teiginiai}

1. Optimalių sąstatų kiekvienam maršrutui parinkimo metodika.

2. Priemoniu parinkimo modelis, ivertinantis ne tik technines riedmenų galimybes, bet ir visas kitas pajamų bei išlaidų sudedamąsias dalis vežant keleivius geležinkelių transportu.

3. Tikslo funkcija skirta vežimèliu pakabų parametrams optimizuoti, esant ivvairiems greičiams, ir iki minimumo sumažinti vagonų virpesius, užtikrinant traukino stovumą ir tolygią eigą.

\section{Darbo rezultatu aprobavimas}

Disertacijos tema išspausdinti 7 moksliniai straipsniai: keturi - mokslo žurnaluose, itrauktuose i Science Citation Index Expanded (Web of Science) sąrašą (Dailydka 2010; Liudvinavičius, Lingaitis, Dailydka, Jastremskas 2009; Dailydka, Lingaitis, Myamlin, Prichodko 2008a; Dailydka, Lingaitis, Myamlin, Prichodko 2008b); du - kituose recenzuojamuose mokslo leidiniuose (Dailydka, Lingaitis 2009; Lingaitis, Dailydka, Myamlin, Prichodko 2008), vienas - recenzuojamame Lietuvos tarptautinès straipsnių rinkinyje medžiagoje (Dailydka 2009).

Disertacijoje atliktų tyrimų rezultatai buvo paskelbti trijose tarptautinèse mokslinèse konferencijose:

- 68-ojoje tarptautinëje mokslinëje-praktinëje konferencijoje „Geležinkelio transporto vystymo problemos ir perspektyvos“ $2008 \mathrm{~m}$. Dniepropetrovske (Ukraina);

- tarptautinèje konferencijoje „TRANSBALTICA 2009“ 2009 m. Vilniuje; 
- IV tarptautinëje mokslinèje-praktinëje konferencijoje „Imlių mokslui technologijų diegimas magistraliniame ir pramoniniame geležinkelio transporte“ $2008 \mathrm{~m}$. Jaremče (Ukraina).

\section{Disertacijos struktūra}

Disertaciją sudaro ịvadas, keturi skyriai ir bendrosios išvados, literatūros sąrašas ir šaltiniai, autoriaus publikacijų sąrašas disertacijos tema bei priedas.

Darbo apimtis - 134 puslapiai be prieduc, tekste naudotos 44 numeruotos formulès, 71 paveikslas ir 36 lentelès. Rašant disertaciją buvo panaudoti 78 literatūros šaltiniai. 



\section{1}

\section{Mokslinès literatūros analizè}

Literatūros apžvalgoje analizuojami keleivių vežimo geležinkeliais tyrimo darbų, atliktų tiek mūsų šalyje, tiek visame pasaulyje, rezultatai dviem aspektais. Pirma, apžvelgiami moksliniai darbai, nagrinejjantys organizacinius keleivių vežimo geležinkeliais klausimus, antra, keleivių vežimo priemonėms tobulinti skirti moksliniai darbai, siekiant pritraukti i geležinkelio transportą kuo daugiau keleivių, taip didinti transporto i̇monių gaunamas pajamas ir mažinti patiriamus nuostolius.

\subsection{Darbai, nagrinėjantys keleivių vežimo organizavimą}

Darbe (Maskeliūnaitè, Sivilevičius, Podvezko 2009) pateikta keleivių vežimo kokybę rodančių veiksnių sieties schema, kurios elementai atitinka apklausos anketos struktūrą. Pateikti skaičiavimo pavyzdžiai, susisteminti ir apdoroti anketiniai keleivių apklausos duomenys, išanalizuota apklausoje dalyvavusių keleivių nuomoné. Pateikiamos tyrimais pagrịstos išvados ir rekomendacijos keleivių vežimo Lietuvos geležinkeliais kokybei gerinti. Ypatingą dėmesį reikia kreipti $\mathfrak{i}$ skirtingus keleiviu poreikius, tikslus ir galimybes. Autoriai tai rekomenduoja 
daryti nuolat rengiant keleivių apklausas, akcentuoja geras komforto sąlygas keleiviams pritraukti.

Straipsnyje (Butkevičius 2009) pagal autoriaus atliktus tyrimus indentifikuotos keleivių vežimo šalies geležinkelių transportu problemos - keleivių srautụ mažejimas, vežimo savikainos augimas, nepakankamas nuostolingo vežimo finansavimas, nevienodos konkurencinès sąlygos su kelių transportu, trūkumai istatymų bazèje ir kt. Remiantis ES patirtimi, siūloma plèsti keleivių vežimą šalies geležinkelių transportu. Straipsnyje pateikti autoriaus parengti siūlymai visuomenès aptarnavimo i̇sipareigojimų vykdymo strategijai formuoti. Siūlymai apima tiek valstybès nuostatų formavimą ir igyvendinimą keleivinio transporto srityje, tiek konkrečias geležinkelių transporto priemones.

Darbe (Butkevičius 2007) išnagrinèti perspektyviniai Vilniaus-Varšuvos maršruto keleivių srautai, pateikti konkurencinès srities keleivių vežimo šiuo maršrutu tyrimų rezultatai, išanalizuoti traukinio paleidimo techniniai ir ekonominiai aspektai, rinkodaros strategija, pateiktos tokio traukinio paleidimo sąsajos su „Rail Baltica“ projektu, atlikta SSGG (stiprybès, silpnybès, galimybès, grèsmès) analizè. Tačiau šio projekto igyvendinimas priklauso nuo kelių Baltijos šalių ir bendro ES požiūrio. Bègant laikui nuomonès keičiasi, pastaruoju metu jaučiami teigiami poslinkiai.

Traukinių eismo programavimas yra nepaprastai svarbus organizuojant keleivių vežimą. Keleivių specialiujų linijų traukinių programavimas gerokai skiriasi nuo kitu esamų linijų. Wang, Cui, Li straipsnyje (2009) nagrinejjamos keleivių specialiosios linijos traukinių programavimo sąlygos, ilgų atstumų keleivių vežimo metodas ir priimtino geležinkelio linijos maršruto atstumo klausimas. Teigiama, kad specialiosios keleivių linijos traukinių programavimas turètų būti sudaromas atsižvelgiant į esamų greitujų linijų traukinių programavimą; ilgujju atstumų keleivių vežimo metodas organizuojamas derinant tarplinijinio traukinio eigą ir keleivių persodinima. Straipsnyje pateikiamas metodas, kaip apskaičiuoti tinkamą specialiosios keleivių linijos atstumą. Apskaičiavus daroma išvada, kad konkurencingas specialiosios keleivių linijos traukinio maršruto atstumas Kinijoje sudaro nuo $100 \mathrm{~km}$ iki $1550 \mathrm{~km}$. Šis metodas galètų būti taikomas tik tuomet, kai keleivių skaičius būtų bent 50 kartų didesnis nei Lietuvoje.

Iš pradžių Zhang, Peng straipsnyje (2008) analizuojama keleivių transporto struktūra ir ypatybès, reikalingos siekiant užtikrinti integruotają transporto sistemą. Keliamos tokios problemos, kaip keleivių persodinimas, traukinių jungčių skaičius, koordinavimas ir bendradarbiavimas, stoties pajègumai. Po to siūlomas integruotaja transporto sistema grindžiamas tinklo modelis ir aprašomas naujas keleivių persodinimo metodas, sukurtas remiantis esama moksline literatūra. Atsižvelgiant $i$ integruotosios transporto sistemos ir keleivių transporto sistemos ypatybes, tinklą sudaro keleivių stotys ir tarp stočių esančių traukinių skaičius. Analizuojant ši modeli išryškinama kombinuota didelio masto integruotuju 
transporto sistemų tinklų optimizavimo, skirtingų transporto modulių derinimo problema, tikslinè eismo organizavimo ivvairovè, susijusi su persodinimo ir tinklo optimizavimo problemomis. Galiausiai, teigdami, kad problemą nesunku išspręsti pasitelkus genetinị algoritmą, autoriai pateikia genetinį algoritmą ir nurodo pagrindinį sprendimo procesą.

Analizuodami geležinkelių keleivinių traukinių planavimo ekonominès naudos elementus, Tao, Peng, Zha, Jiang (2007) straipsnyje pateikia skaičiavimo metodą, pagal kuri gali būti apskaičiuotos ịplaukos, sąnaudos, ekonominė nauda ir nenuostolingas keleivinių traukinių srautas. Pabaigoje pateikiamas pavyzdys, kuriuo parodoma, kad keleivių traukinių planavimo ekonominis vertinimas yra praktiškas ir igyvendinamas. Jis gali padèti priimant sprendimus dèl geležinkelių keleivių vežimo sistemos komercinès plètros. Modelis vèlgi neįvertina socialiai būtinų, bet nuostolingų ruožų eksploatacijos.

Pastaruoju metu geležinkelių keleivių transporto sistema sparčiai plečiasi, veržliai tiesiamos specialiosios keleivių linijos, tačiau tuo pačiu metu vis svarbesnè traukinių vèlavimo problema. Siekiant pritraukti daugiau keleivių ir pagerinti keleivių transporto struktūra, naudojama periodinè traukinių diagrama (Bao, Xin, Tang, Zang 2009), skirta spręsti problemą trimis - atstumo, rezervuotų linijų naudojimo ir traukinių sustojimų - aspektais.

Geležinkelių linijų ir stočių lokalizavimas yra sudètinga problema, nes galimų pasirinkimų skaičius yra tiesiog astronominis, reikalavimų ir apribojimų labai daug, o kiekvieno pasirinkimo vertinimas grindžiamas daugybe veiksmingumo skaičiavimų. Be to, norint apskaičiuoti tam tikrus veiksmingumo dydžius, reikalingas didžiulis ịvairaus pobūdžio geografinès informacijos kiekis. Pavyzdžiui, norint ịvertinti tranzito stočių prieinamumą ir su tuo susijusi prieigos laiką bei ịtaką paklausai, reikalingi detalūs erdviniai duomenys apie namų ūkių padètị ir pobūdị. Norint ịvertinti statybos sąnaudas, būtina detali informacija apie esamus kelių tinklus, topografiją ir geologiją, o norint nustatyti geležinkelio ruožo sąnaudas reikalinga nuodugni informacija apie žemès naudojimą ir žemès kainas. Manoj, Schonfeld, Sutapa (2007), straipsnyje spręsdami geležinkelių linijų optimizavimo problema, pasitelkia genetinị algoritmą ir geografinès informacijos sistemą. Pagal pasirinktaji modelị nustatomos ir ịvertinamos dviejų tipų sąnaudos: 1) operatoriaus sąnaudos, kurias sudaro su geležinkelių tiesimu susijusios sąnaudos, stočių statybos sąnaudos, geležinkelio ruožo, žemès darbų ir traukinių operavimo sąnaudos; 2) vartotojo sąnaudos, kurias sudaro prieinamumo kaina, kelionès ir laiko, praleisto laukiant, sąnaudos. Modelis pritaikytas Anne Arundel apygardos (Merilendas) segmentui, siekiant naujai optimizuoti tarp dviejų stočių esančią lengvojo traukinio tranzito linija, jungiančią Glen Burnie miestą ir Baltimorès Vašingtono tarptautinį oro uostą. Čia pristatomas prototipinis modelis pagal naudotus kriterijus duoda labai gerų rezultatų ir jis gali būti pritaikytas atliekant išsamesnius ir sudètingesnius vertinimus. Kartu aptariami 
papildomi veiksniai ir išlaidų komponentai, jei taikomi sudètingesni modeliai. Šis modelis iš dalies galètų būti taikytinas „Rail Baltica“ linijai, jungiančiai Varšuvą ir Taliną.

Analizuojamos sisteminès Rusijos transporto sistemos problemos (Filina 2008), kliudančios jai plèstis ir jos konkurencingumui augti. Apžvelgiama pagrindinių atskirų transporto rūšių rodiklių dinamika, aptariami teritoriniai transporto infrastruktūros pakankamumo skirtumai, problemos, susijusios su sparčiai augančiu lengvujų automobilių skaičiumi keliuose, tranzito potencialo naudojimo klausimai. Ypač daug dèmesio skiriama geležinkelių transporto konkurencingumui, pristatomos ilgalaikès geležinkelio plètros strategijos.

Budai, Maróti, Dekker, Huisman, Kroon (2010) straipsnyje nagrinèjama vadinamoji geležinkelių riedmenų pusiausvyros atkūrimo problema (toliau GRPAP), kuri kyla keleivinio geležinkelių transporto operatoriams, kai dėl kintančiu aplinkybių būtina keisti tvarkaraščius. GRPAP aktuali tiek vykdant trumpalaiki planavima, tiek vykdant operacijas realiuoju laiku.

GRPAP daro itaką tvarkaraščiui ir geležinkelio riedmenų judejjimui, kai riedmenų paskirstymas tarp stočių tam tikro planavimo laikotarpio pradžioje ir pabaigoje nesutampa su paskirstymu prieš ar po planavimo periodo. Tada kyla klausimas - kaip sutvarkyti esamą riedmenų judejimą taip, kad likusių neatitikimų skaičius būtų kuo mažesnis. Išsprendus visas neatitikimų problemas, gautą riedmenų judèjimo tvarką galima taikyti praktiškai.

Tam, kad GRPAP sprendimus būtų galima taikyti praktiškai, svarbu problemą spręsti greitai. Teigiama, kad GRPAP yra eksponentinès (NP) klasės algoritmo tipo, todèl dèmesys kreipiamas ị euristines (loginių ir metodinių taisyklių visuma) sprendimo paieškos prieigas: aprašomi du euristiniai variantai ir lyginami tarpusavyje, atsižvelgiant ị realius pagrindinio Nyderlandų keleivinių geležinkelių linijų operatoriaus pavyzdžius. Galiausiai pasiūlytų euristinių variantų kokybei įvertinti jų rezultatai lyginami su geriausiais sprendiniais, gautais sprendžiant esamo geležinkelio riedmenų judejjimo modelio problemas.

Geležinkelių tinklo naudojimo optimizavimo problemos sprendžiamos pasitelkus vadinamają judejjimo tyrimo strategiją (angl. Walk Search Strategy). Siūlomas algoritmas, kuriuo geležinkelių tinklas tiriamas atsižvelgiant i keleivio judejjimo ribas. Remdamasis keliomis pasirinkimo taisyklèmis, keleivis gali dinamiškai nustatyti geriausią traukinių judejjimo kelią. Pateikti du skaičiavimų pavyzdžiai, kuriais išbandomas judejjimo tyrimo algoritmas geležinkelio tinklo daliai ( $\mathrm{Li}, \mathrm{Gao}, \mathrm{Mao}, \mathrm{Cao}$ 2009). Rezultatai rodo, kad siūloma prieiga yra veiksminga priemonè optimizuoti geležinkelių tinklo naudojimo problemą. Tačiau toks algoritmas netinka Lietuvos geležinkelių tinklo sąlygomis, nes judejjimo kryptys gana ribotos.

Ir transporto bendrovei, ir keleiviui svarbu, kad būtų sukurtas tarpmiestinių keleivinių traukinių veiklos planas ir nustatyta bilietų kaina. Šiuo metu pasaulyje 
plačiai vykdomi tyrimai, susiję su šiomis dviem problemomis. Manoma, kad būtent jų sprendimas yra ypač vertingas geležinkelių transporto įmonèms priimant sprendimus. Analizuojant šias problemas, tiriama tarpmiestinių keleivinių traukinių transporto sistema ir daroma išvada, kad pagrindiniai veiksniai ateityje, darysiantys itaką keleivių srautui, bus tarpmiestinis keleivių vežimo veiklos planas ir bilietu kainos. Pateikiamas daugiatikslis modelis (Hu, Yan, Qiu 2008), kuriuo remiantis sudaromas tarpmiestinio keleivių vežimo veiklos planas ir nustatomos bilietų kainos. Toks modelis taikomas keleiviams vežti tarp Chengdu ir Chongqing vietovių.

Tyrimai (Кузнецова 2007) rodo, kad pagrindinès priemiestinių traukinių paslaugu charakteristikos yra šios: mažas pareikalavimas, žemas pelningumas, nèra tinkamos reklamos, tradicinès paslaugos nusibodo vartotojams, jie laiko jas neprestižinèmis ir rado joms pakaitalą. Kai keleivių vežimo paslaugų rinkoje pasirode papildomai komerciniai autobusai ir maršrutiniai taksi, daugelis buvusių geležinkelio keleivių liovèsi naudotis šia paslauga ir atidavè pirmenybę alternatyviems vežimams (automobiliams) ir dèl to poreikis važiuoti priemiestiniais geležinkeliais sumažèjo. Taigi norint susigrą̌žnti buvusius geležinkelio klientus ir pritraukti naujus, būtina taikyti racionalias organizacines ir technines priemones, patogias keleiviui, garantuojant komforto sqlygas traukiniuose.

Darbe (Морозова 2009) nagrinejjamos eksploatacinių išlaidų mažinimo rezervinès galimybès gerinant kokybinius eksploatacinius geležinkelio riedmenų rodiklius atskiriant keleivių vežimo įmones pagal teritorines ir funkcines organizacines-gamybines struktūras. Mūsų šalies sąlygomis tai nèra taikytina, nes keleivius geležinkeliais veža vienintelè i̇monè - $A B$,Lietuvos geležinkeliai“, be to, tai nebūtų tikslinga esant palyginti nedidelei teritorijai ir santykinai mažam keleivių skaičiui.

Disertacijoje (Лисенко 2006) analizuojama geležinkelių imonès veikla išskiriant techninius einamujų išlaidų valdymo aspektus. Nustatyta, kad pagrindines išlaidas sudaro išlaidos geležinkelio riedmenų traukai (riedmenų eksploatacija (46 proc.) ir lokomotyvų brigadų išlaikymas (40 proc.) nuo bendros išlaidų apimties). Tai leidžia teigti, kad personalo skaičius ir priežiūros darbų imlumas bei riedmenu remontas yra pats svarbiausias veiksnys nagrinèjant išlaidų dinamiką. Taigi, diegiant pažangias technologijas, galima gerokai sumažinti aptarnaujančiojo personalo skaičių, kartu mažinti ir bendrąsias išlaidas.

Autorius nagrinèja viso priemiestinio keleivių vežimo komplekso efektyvumą, remdamasis integraliniu (suminiu) finansiniu rezultatu. Disertacijoje nurodoma, kad pagrindinès išlaidos susijusios su gausiu personalo skaičiumi bei riedmenų remontu ir priežiūra. Nagrinëjama daugybẻ lengvatinių sąlygų, teisinė sistema, organizacijų visuma, kurios kompensuoja dalį išlaidų ir pan. Mūsų atveju paslaugų veiksniai nelemia bendrujų išlaidų. 
Darbe pateikti orientaciniai duomenys apie kompensacijų apimtis keleiviniam geležinkelių transportui kitose šalyse (1.1 lentelè).

1.1 lentelè. Vidutinès metinès kompensacijų apimtys keleiviniam geležinkelių transportui ivvairiose pasaulio šalyse

Table 1.1. The average annual compensation for passenger rail transport in the different countries

\begin{tabular}{|c|c|c|c|}
\hline Šalis & $\begin{array}{l}\text { Imonè, vežanti } \\
\text { keleivius }\end{array}$ & $\begin{array}{l}\text { Vidutinè valstybinè } \\
\text { metine } \\
\text { kompensacija*, mln. } \\
\text { EUR }\end{array}$ & $\begin{array}{l}\text { Vidutinè valstybinè } \\
\text { metine } \\
\text { kompensacija*, } \\
\text { euro centais/kel. km }\end{array}$ \\
\hline JAV & $\begin{array}{l}\text { Amtrak } \\
\text { (valstybinė imonè) }\end{array}$ & 900 & 12 \\
\hline Kanada & $\begin{array}{l}\text { VIARAIL } \\
\text { (valstybinė imonè) }\end{array}$ & 1800 & 13,8 \\
\hline Prancūzija & $\begin{array}{l}\text { SNCF (valstybinis } \\
\text { vežejas - krovinių ir } \\
\text { keleivių vežimas) }\end{array}$ & 1731 & 2,5 \\
\hline Vokietija & $\begin{array}{l}\text { Antriné DBAG imo- } \\
\text { nè ir panašios įmo- } \\
\text { nès }\end{array}$ & 4300 & 5,9 \\
\hline $\begin{array}{l}\text { Didžioji } \\
\text { Britanija }\end{array}$ & Privačios i̇monės & 1727 & 4,5 \\
\hline
\end{tabular}

*Duomenys be subsidijų infrastruktūrai išlaikyti.

Viešojo transporto (Celebi, Bolat; Bayraktar 2009) strateginio ir detalaus planavimo sèkmè labai priklauso nuo informacijos apie poreikius tikslumo. Trumpalaikès prognozės yra tokių transporto operacijų, kaip eismo tvarkaraščių sudarymas ir vietų paskirstymas, pagrindinis sẻkmingo planavimo elementas. Trumpalaikių keleiviu poreikių prognozavimo modeliams, kurie bus naudojami lengvojo geležinkelio transporto eksploataciniam valdymui, parengti šioje studijoje naudojama Neural Networks technologija. Daugiasluoksnio suvokimo (MLP) modelis pasirenkamas ne tik dèl paprastos architektūros, bet ir dèl sèkmès sprendžiant suderinamumo problemas. Siekiant išvengti svarbaus tvarkaraščių laikų sezoniškumo, kiekvienas tvarkaraščio laikas nagrinejjamas individualiai ir atskirai nuo kitų, kiekvienam jų remiantis kiekvienos dienos informacija bus parengta dirbtinè Neural Networks programa. 74 skirtingiems tvarkaraščio laikams naudojant surinktą ankstesnę informaciją parengiamos 74 programos. Vienam grafiko laikui pateikiami trys iliustratyvūs pavyzdžiai, o prognozių modelių veiksmingumas vertinamas remiantis vidutiniu kvadratiniu paklaidų dydžiu (MSE) ir vidutiniu absoliučiu paklaidų procentiniu dydžiu (MAPE). 
Kelių ir geležinkelių transportas konkuruoja veždami keleivius (Butkevičius, Jarašūnienè, Jackiv 2008). Kaip alternatyvios transporto rūšys, automobilių kelių ir geležinkelių transportas lyginami pagal vežimo sąnaudas, tarifus, energinius ir aplinkosaugos aspektus, transporto priemones ir riedmenų parką, pagal investicijas šioms transporto rūšims. Tačiau vienas svarbiausių transportavimo rodikliu yra eismo saugumas. Šiame straipsnyje lyginamas automobilių ir geležinkelių transportas eismo saugumo požiūriu, kur prioritetas teikiamas geležinkeliams.

Geležinkelių transportas, vežant Lietuvos keleivius ir krovinius, vaidina svarbų vaidmeni. Transporto rinkoje jis konkuruoja su kitomis transporto rūšimis, tokiomis kaip automobilių kelių jūrų ir oro transportas. Gabenimo geležinkelio transportu procesui tobulinti labai svarbu žinoti jo stipriąsias ir silpnąsias puses bei galimybes. Todèl Butkevičiaus straipsnyje (2008) atskirai pateikiama keleivių ir krovinių vežimo geležinkeliu SSGG (stiprybių, silpnybių, galimybių, grèsmių) (angl. SWOT, Strengths, Weaknesses, Oppurtunities, Threats) analizė.

Buvo atlikta nemažai skirtingų studijų, nagrinèjančių išsivysčiusių šalių ir jų keleivių vežimo proceso efektyvumą. Nepaisant to, suformuotas nedidelis supratimas apie pasaulio geležinkelio sektoriaus, o ypač keleivių segmento rezultatus. Hilmola darbe (2009) ilgalaikès perspektyvos rezultatams vertinti naudojami du duomenų aplinkos analizės efektyvumo nustatymo modeliai. Tyrimų rezultatai parode, kad nepaisant to, koks modelis naudotas, dominuoja Japonija, o skirtumai tarp šalių bei regionu yra ryškūs. Tačiau galima daryti bendrą išvadą, kad po 1990 metu vidutiniškai keleivių vežimo rodikliai pagerèjo, tai ypač išryškinta keleivių kilometrų DEA (aplinkos duomenų analizès) modelyje.

Vienas svarbiausių parametrų nustatant optimalią transportavimo sistemą yra ekonominè nauda. Dèl to sąnaudų analizei reikalingas metodas, kuris būtų pagrịstas techniniais, ekonominiais ir eksploataciniais ỉvairių transporto rūšių, $\mathrm{o}$ būtent automobilių kelių, geležinkelių ir jūrų keliu̧, parametrais. Taikant ši metodą (Sahin, Yilmaz, Ust, Guneri, Gulsun 2009), įvertintas galimas kainų kilimas tam tikros transporto sistemos gyvavimo laikotarpiu. Turi būti ịvertintos krovinio vieneto gabenimo arba keleivių vežimo sąnaudos kelio ilgiui, nes tai yra ekonominis rodiklis. Šiame darbe pateikiamas transporto pajamų ir išlaidų analizès būdas, paremtas krovinių ir keleivių vežimo alternatyviomis transporto rūšimis ekonomine analize.

Europos Sajunga investuoja daug lèšų i transporto sistemos modernizavimą ir transporto infrastruktūros darninimą. Dèl vežimo geležinkeliais pastaraisiais metais buvo priimta nemažai teisinių dokumentų, susijusių su krovinių ir keleivių vežimu, sauga, licencijų ir paslaugų kokybès suvienodinimu. Europos Komisijos reglamentas Nr. 1371/2007 dèl keleivių teisių ir pareigų kartu su Direktyva 2007/58EC dèl tarptautinių keleivių paslaugu liberalizavimo ir Direktyva 2007/59EC dèl traukinių mašinistų licencijavimo yra bendrai vadinami „Tre- 
čiuoju geležinkeliu paketu“. Tai naujausi dokumentai iš serijos, skirtos atgaivinti geležinkeliams ir pasistūmèti i prieki kuriant integruotą Europos geležinkelio tinklą. Europos reglamentas dèl keleivių teisių ir pareigų nustato geležinkelio keleivių teises ir pareigas, kad geležinkelio keleivių transportas būtų efektyvesnis ir patrauklesnis (Durdev 2009).

Paprastai transporto sektoriaus dalyviai vertinami nacionaliniu arba imonès lygmeniu pagal daugelị rodiklių neišryškinant visos sistemos veiklos ir šių rodiklių esmès (riba tarp indèlio ir rezultato yra neaiški). Tyrime (Savolainen, Hilmola 2009) siūlomi duomenų aplinkos analizès (DEA) efektyvumo modeliai, skirti krovinių ir keleivių transportui tiek oro keliais, tiek geležinkeliais. Analizès, atliktos platesnejje Europoje, rezultatai parodè, kad skiriasi daugiausia geležinkelio operacijų efektyvumas, tačiau dalyvių specializacija yra abiejuose transporto sektoriuose.

Imitaciniai modeliai, atspindintys transporto sistemų eksploatavima, turetų naudotis atitinkamų sprendimų priemimo procesų realizacija. Šiame kontekste reikia suformuoti arba atrinkti atitinkamus modelius ir metodikas. Demesys skiriamas specifinei eksploatacinei problemai, susijusiai su platformos kelių paskyrimu vèluojantiems traukiniams keleivinių geležinkelio stočių imitaciniame modelyje. Tirtas (Bažant, Kavička 2009) dvisluoksnès Neural Network technologijos naudojimas darant sprendimus minetai kelio paskyrimo problemai spręsti. Nagrinejjant nurodytą problemą ši Neural Network programa parodè daug žadančius rezultatus, dèl kuriu galimas pelningas jos naudojimas. Tai reiškia, kad kyla atitinkamų imitacinių modelių kokybe ir turi būti padidintas iš to išplaukiantis imitacinių studijų geležinkelio imonèms patikimumas.

Pastaraisiais metais modernioms keleivių informavimo sistemoms keliami vis aukštesni reikalavimai. Tradicines sistemas dažniausiai sudaro daugybe posistemių, kurie vis labiau arteja prie eksploatacijos ribų. Naujoji Ruf grupès VisiWeb keleivių informavimo sistema yra paremta visu funkcijų idiegimo bendroje sistemoje ir komunikavimo Ethernet koncepcija (Schraven 2008). Priklausomai nuo kliento reikalavimu, VisiWeb gali turèti vaizdo stebejjimo galimybę, monitorius, akustines sistemas, keleivių skaičiavimo sistemas, borto kompiuterius ir informacijos bei avarinius vidaus telefonus; sistema gali būti plečiama be galo. Idiegti riedmenyse programų moduliai, naudojant standartines sąsajas su kitomis programomis, papildomi eismo tvarkaraščiu informacijos rinkimo galimybėmis.

Išsivysčiusių ir besivystančių šalių didmiesčiuose ilgesnėms kelionėms parenkamos dvi ar daugiau transporto rūšys. Jei galima rinktis priemiestinius traukinius ar visuomenini autobusų transporta, priemiesčių gyventojai mieliau ilgesniems atstumams renkasi traukinius, kad galètų išvengti spūsčių keliuose, o jeigu jų galutinè kelionès vieta nèra arti geležinkelio stoties, tai likusią kelio dalị važiuoja autobusais. Paprastai priemiestiniai traukiniai turi iš anksto nustatytus 
koridorius, o autobusai lanksčiai vyksta ị tolimesnes vietoves. Taigi privažiuojamujjų kelių maršrutų nuo geležinkelio stočių iki įvairių paskirties vietų projektavimas ir persédimo iš traukinio į autobusą laikas yra labai svarbus ir gali būti transporto planuotojų valdomas. Atlikta nemažai atskirų autobusų maršrutų tinklų tyrimų nevertinant traukinių paslaugu daromos itakos (Shrivastava, O’Mahony 2009). Tyrinètojai keliams ir tvarkaraščiams projektuoti bei sudaryti taikè euristinius metodus, imitavima, ekspertines sistemas, dirbtini intelektą ir optimizavimo technologijas. Iki šiol tebuvo ribotos pastangos sumodeliuoti koordinuotus veiksmus. Siame moksliniame darbe aptariamas naujojo hibridinio algoritmo, kuriame naudojami genetinių algoritmų ir gerai išbandytų euristinių algoritmų privalumai, taikymas moksle. Tiriant privažiuojamujų kelių maršrutus ir koordinuotus tvarkaraščius pasirinktose geležinkelio stotyse, palyginti su būdais, kuriuos anksčiau autoriai taikè panašioms studijoms, itikinamesnių rezultatų gaunama naudojantis siūlomu hibridiniu algoritmu.

Kasturia, Verma darbe (2010) pateikiamas daugiatikslès apibendrintomis sąnaudomis (GC) grisstos keleivių informavimo sistemos (PIS) projektavimas ivairiarūšei transporto sistemai, kurioje integruoti geografinès informavimo sistemos (GIS) apdorojimas, tinklo analizè, ryšys su vartotojais ir duomenų bazès valdymas. GC maršrutų planavimo būdas ypač svarbus nagrinejjant indiškaji scenarijų, kur paprastai skirtingos transporto rūšys nèra darninamos, o persèdimo laikas iš vienos transporto priemonès į kita yra labai ilgas. Jame taip pat imituojama natūrali visuomeninio transporto vartotojų tendencija skirtingą dėmesị skirti ịvairiems kelionès svertams (ejjimas pėsčiomis, laukimas, kelionės laikas, etc.). Planuojant kelionę siūloma PIS duoda atsakymus i tokius vartotojų klausimus, kaip optimalus kelias laiko, sąnaudų, atstumo atžvilgiu ar bendrosios sąnaudos, ir suteikia kitą kelionei planuoti reikalingą informaciją. Ji įdiegta ịvairiarūšiame integruotame tranzitiniame tinkle, anksčiau suprojektuotame Indijos miestui Thane.

Reziumuojant keleivių vežimo traukiniais tyrinejjimo aspektus, galima teigti, kad norint padaryti keleivini geležinkelių transportą efektyvesni, būtina pagrindinị dèmesị kreipti į veiksnius, pateiktus 1.1 pav. 


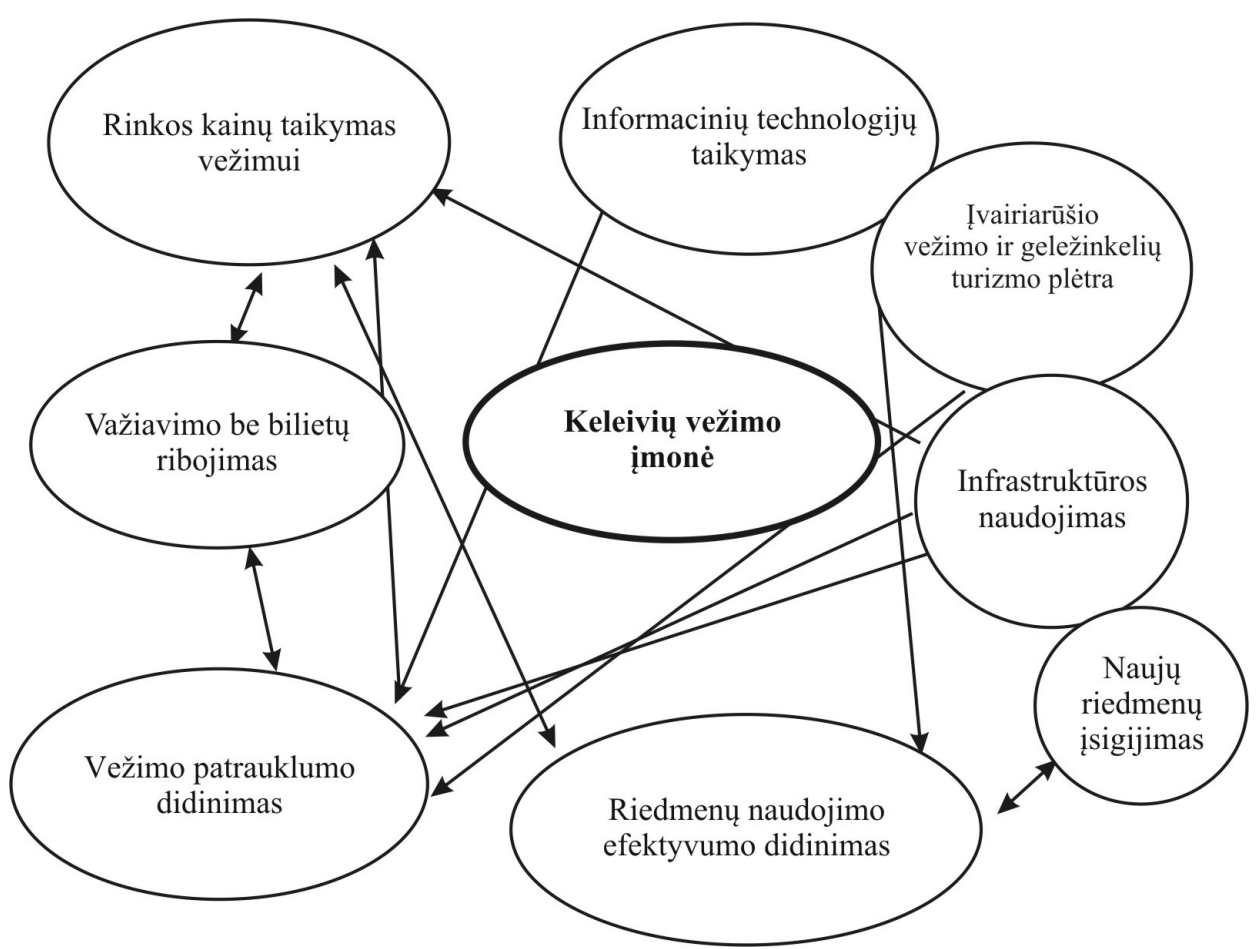

1.1 pav. Priemiestinių keleivių vežimo tinklo plètros aspektai

Fig. 1.1. Suburban passenger transport network development aspects

Apžvelgtos pasaulinès mokslinès tendencijos, ieškant racionalių keleivių vežimo metodų, rodo, kad pagrindinis demesys skiriamas dideliems keleivių srautams ir ilgiems atstumams. Tačiau pasauliniu mastu beveik nèra darbu keleivių vežimo organizacinių techninių sprendimų klausimais, kai keleivių srautai ir atstumai nèra dideli (iki $400 \mathrm{~km}$ ), t. y. atitinkantys Lietuvos sąlygas.

\subsection{Darbai, susiję su komforto gerinimu}

Visos priemonès yra svarbios, tačiau mūsų šalies sąlygomis itin svarbu gerinti riedmenų naudojima, t. y. kuo racionaliau naudoti jau esamus riedmenis keleiviams vežti, o įsigyjant naujus stengtis, kad juose būtų sudarytos kuo palankesnès sąlygos (komfortas) keleiviui. Tam turi būti sumažintos vagonų vibracijos, itin kenkiančios keleivio sveikatai, savijautai, taikomi pažangiausi ergonominiai sprendimai bei priežiūra. Daug tyrimų pasaulyje atlikta ir atliekama parenkant optimalius keleivinių vagonų vežimèlių pakabų parametrus, kurie, didejjant traukinių greičiams, dažniausiai išreiškiami dinaminiais koeficientais. Jie, nepaisant 
augančių važiavimo greičių, negali išeiti už leistinų ribų, nustatytų specialiu standartu (Mechaniniai virpesiai ir smūgiai... 2004).

Toliau apžvelgiami pagrindiniai darbai, nuveikti šioje srityje.

Kai kurie tyrinètojai (Реклейтис, Рейвиндран, Рэгсдел 1986) nagrinejja keletą metodiku, parinkdami tikslo funkciją pakabų parametrams nustatyti. Tai vieno pagrindinio kokybès kriterijaus optimizavimas. Pvz., gali būti optimizuojamas svoris, vagono važiuoklès ilgis, traukos kokybè, kaina ir kt. Kitiems kriterijams naudojami apribojimai. Kitu atveju sudaroma optimali Pareto aibe ir parenkamas tinkamiausias sprendinys. Išvadose teigiama, kad tikslingiausia, optimizuojant važiuoklę, optimizuoti vieną kriterijų (pagrindini), tai leistų uždavinio sprendimą maksimaliai priartinti prie realių sąlygų. Tokio optimizavimo silpnoji vieta ta, kad keičiantis eksploatavimo sąlygoms (pvz., didejjant traukinių greičiams) kiti kriterijai gali tapti pagrindiniais. Todèl pastaruoju metu daugelis tyrinètojų renkasi daugiakriterinį optimizavimą.

Disertacijoje (Михайличенко, 1986) vertinami rodikliai, kurie nusako dinamines riedmenu charakteristikas. Juos sąlygiškai galima suskirstyti i tris grupes: rodikliai, veikiantys keleivius ir aptarnaujanti jų personala; rodikliai, veikiantys važiuoklių elementus; rodikliai, veikiantys bėgių kelią.

Dinaminėms savybėms vertinti dažniausiai naudojami šie kriterijai: vertikalūs ir skersiniai kèbulo, vežimèlio rẻmo ir ašidėžių pagreičiai; eigos tolygumo koeficientas, vertinantis važiuoklès dinamikos itaką žmogui; pakabos spyruoklių deformacija ir visų pakabos pakopų dinamika; santykiniai kèbulo ir vežimèlio poslinkiai bei jègos. Pažymima, kad pagrindinis kriterijus, lemiantis saugų eismą, yra šoninès jègos, atsirandančios tarp rato ir bègio.

Pastaruoju metu vertinant riedmens dinamiką horizontaliojoje plokštumoje, naudojamasi jègomis, veikiančiomis rèmą. Tačiau šios jègos iš principo apskaičiuojamos įvertinant išsvertas mases horizontaliojoje plokštumoje, o neišsvertu masių poveikis lieka neịvertintas.

Parametrinè optimizacija, kaip geriausių parametrų reikšmių paieškos procesas, gali būti atliekama skirtingais metodais. Pirmiausia skaičiuojant tikslo funkcijos reikšmes parametrų erdveje. Optimalaus sprendinio paieška šiuo atveju pasireiškia tuo, kad parenkama tinkamiausia tikslo funkcijos reikšmè (Ковалев 2004).

Kitas metodas grindžiama tuo, kad naudojami skirtingi nelinijinio programavimo algoritmai. Tokiems optimizacijos metodams skirti Polak darbai (1974, 1983).

Kompiuterinès realizacijos techninių sistemų optimizavimo metodai, tarp jų ir geležinkelio važiuoklių, nagrinejjami kai kuriuose darbuose (Ковалев 2004; Реклейтис, Рейвиндран, Рэгсдел 1986; Bestle, Eberhard 1992, 1994, 1996; Schiehlen 1997). 
Atlikta šių algoritmų analizè tarp nulinès eilès metodų leidžia išskirti Huko-Dživso, Nelderio-Mido ir gretutinių krypčių Pauelo metodą, o tarp pirmos eilès metodų - Devidono, Fletčerio, Pauelo metodą kaip patikimą bei tikslų. Šis metodas pastaruoju metu taikomas dažniausiai.

Be skenavimo metodo, sprendžiant globalius optimizacijos uždavinius taikomi ir kiti metodai. Juos galima suskirstyti i tokias grupes:

1. Metodai, kurių pagrindą sudaro lokalinès paieškos metodai.

2. Tiesioginiai globalinès paieškos metodai: genetiniai algoritmai, imitacijos metodas, DIRECT metodas.

3. Metodai, naudojantys paviršiaus atspindžio aproksimaciją ir (arba) skaičiavimo schemas.

Dalis pirmos grupès darbų apžvelgta (Erikson, Arora 2002).

Metodų esmè ta, kad nuosekliai taikomi lokalinès paieškos metodai iš skirtingų, atsitiktiniu būdu nustatomų pradinių taškų. Metodai negarantuoja, kad nustatytas globalus optimumas ir yra tikimybinio pobūdžio. Darbe (Реклейтис, Рейвиндран, Рэгсдел 1986) pateiktas vadinamasis kompleksų metodas, kurio esmè ta, kad atsitiktiniu būdu ,išmètoma“ daug taškų erdvejje parametrų, kurie sugrupuojami i tam tikrą optimumo zoną. Kuo daugiau pradinių taškų, tuo didesnè tikimybè, kad nustatytas optimumas yra globalus.

Pažymètinas Šnymano metodas (Snyman 1983), kuris modeliuoja sunkaus taško nuleidimą nuo „kalvelès“. Laikoma, kad taškas pereina lokaliuosius minimumus iš inercijos ir sustoja globaliame minimume.

1993 m. Jones D. R. su bendraautoriais (Jones, Perttunen, Stuckman 1993) pasiūlè DIRECT metodą. Pagal ši metodą erdvè suskirstoma i stačiakampes sritis ir apskaičiuoja tikslo funkcijos reikšmę kiekvieno stačiakampio centre. Pagal tikslo funkcijos reikšmę ir stačiakampio matmenis, šiuo metodu surandamos globalaus optimumo sritys su didžiausia tikimybe. Toliau išskirtos sritys skaidomos i smulkesnes ir taip elgiamasi iki tol, kol srities matmuo pasiekia tam tikrą iš anksto nustatytą dydị.

Jefimovos darbe (Ефимова 2009) analizuojama keleivinių vagonų kūrimo istorija Rusijoje nuo $1846 \mathrm{~m}$. iki $2006 \mathrm{~m}$., atkreipiant pagrindini demesi $i$ technines vagonų ir jų dalių charakteristikas bei jų kitimą laikui bėgant. Autoré pateikia keleivinių vagonų vežimèlių konstrukcijų charakteristikų kitimo raidą, tenkinant augančius traukinių greičius ir keleivių komfortą akcentuodama belopšius vežimèlius, kurie geriausiai apsaugo keleivius nuo tokių neigiamų veiksnių, kaip pagreičiai, vibracijos, triukšmas, taip pat garantuoja tolygią eigą. Taigi viena iš pagrindinių krypčių negatyviems požymiams keleiviniuose traukiniuose šalinti tobulinti vežimèlių (jų pakabų) konstrukcijas.

Keršys, Bazaras (2001) nagrinejja kelio nelygumus bei greičio itaką vagonų mazgu ir viso kèbulo virpesiams, o tai mažina keleivių komfortą. Pateikiami galimi traukinių greičiai priklausomai nuo kelio parametrų, t. y. vyraujančių 
nelygumu pobūdžio. Norint sumažinti virpesius vagone, būtina tobulinti vežimèlių pakabas ir mažinti kelio sužadinimo jègas.

Pagal pateiktas optimizavimo metodikas yra sukurta daugelis kompiuteriniu programų, tokių kaip Mathcad, 3DSmax, Simulink, MEDYNA, ADAMS/CAR, ADAMS/RAIL, DYNRAIL, tarp jų ir geležinkelio pakaboms skaičiuoti.

Apklausos rezultatai (Viešojo transporto efektyvaus panaudojimo... 2010) parodè, kad, keleivių nuomone, keliavimo traukiniais patrauklumas mažeja dèl ivairių priežasčių, tačiau pagrindinès iš jų yra ilgas kelionès laikas ir komforto trūkumas. Todèl šiame darbe pagrindinis dèmesys bus kreipiamas ne tik i geresni keleivinių traukinių darbo organizavima, bet ir priemones, gerinančias keliautojų komforta, mažinančias vibracijas keleiviniuose vagonuose.

\subsection{Pirmojo skyriaus išvados ir disertacijos uždavinių formulavimas}

Apžvelgus keleivių vežimo traukiniais tyrinèjimo aspektus, galima teigti, kad norint padaryti keleivini geležinkelių transportą efektyvų, visų pirma būtina kreipti dèmesi i šiuos veiksnius: riedmenų naudojimo efektyvumo didinima, naujų riedmenų i̊sigijimą, vežimų patrauklumo didinima, rinkos kainų taikymą vežimui, informacinių technologijų taikymą. Mokslinių darbų, susijusių su keleivių vežimo metodais, analizè rodo, kad pagrindinis dèmesys skiriamas dideliems keleivių srautams ir ilgiems atstumams. Tačiau beveik nèra darbų, kuriuose pasauliniu mastu nagrinėjami keleivių vežimo geležinkeliais klausimai, kai keleivių srautai ir atstumai nèra dideli, t. y. atitinkantys Lietuvos sąlygas.

Literatūros analizè parodè, kad keliavimo traukiniais patrauklumas (mūsų sallygomis) mažèja dèl ịvairių priežasčių, tačiau pagrindinès iš jų yra komforto trūkumas ir nepakankamas traukinių kursavimo dažnis. Svarbiausias veiksnys, darantis neigiamą poveiki keleiviams, yra vagonų vibracija. Jai sumažinti vagonų konstrukcijose skirta vežimèliu pakaba. Todèl jos elementu parinkimo optimizavimas yra būtina sąlyga komforto salygoms gerinti. Tai privalu ivertinti isigyjant naujus riedmenis. Tam tikslui numatoma:

1. Ištirti esamą padètị keleivių vežimo geležinkeliais sektoriuje, nustatyti jo reikšmę šalies ūkiui.

2. Nustatyti keleivių vežimo geležinkeliais pajamų ir išlaidų komponentes bei identifikuoti jų priklausomybę nuo techninių riedmenų parametrų.

3. Sudaryti keleivių vežimo geležinkeliais racionaliu priemonių parinkimo modeli. 
4. Modeliui taikant netiesinių lygčių su daugeliu kintamujų ir apribojimais ekstremumo paieškos metoda, parinkti riedmenis konkretiems maršrutams keleivių vežimo Lietuvos geležinkeliais pavyzdžiu.

5. Mažinti vibracijas vagonuose parenkant racionalius parametrus vežimèlių pakaboms, esant ịvairiems greičiams, siekiant sudaryti patrauklias kelionès sąlygas. 


\section{2}

\section{Keleivių vežimo geležinkeliais esamos padėties ir perspektyvu tyrimas}

Bendras Lietuvos geležinkelių tinklas nèra didelis, jis sudaro apie $2000 \mathrm{~km}$ vienkelių ir dvikelių. Pastaruoju metu didžiausieji greičiai atskiruose ruožuose siekia iki $120 \mathrm{~km} / \mathrm{h}$. AB „Lietuvos geležinkeliai“ 2007-2030 metų strategijoje numatomas keleivinių traukinių paros intensyvumas pavaizduotas 2.1 pav.

Keleivinių traukinių eismo intensyvumas, ypač Lietuvos sąlygomis, lemia pritraukiamų keleivių i geležinkelių transportą srautą ir kartu už parduotus bilietus gautas pajamas. Antra vertus, būtina apskaičiuoti, ar didinant reisų skaičių atsipirks patiriamos išlaidos. Šiam uždaviniui spręsti galètu padèti konkrečiu maršrutų geležinkelio transporto priemonių parinkimas. Reikia detalios padèties analizès, kad galima būtų priimti sprendimus tobulinti keleivių vežimo technologiją. Šiame skyriuje analizuojama esama Lietuvos geležinkelių sistemos padetis pagal atskirus maršrutus, identifikuojamos keleivių vežimo sektoriaus problemos bei perspektyviniai uždaviniai, keleivinio parko būklè, investicijų poreikis. 


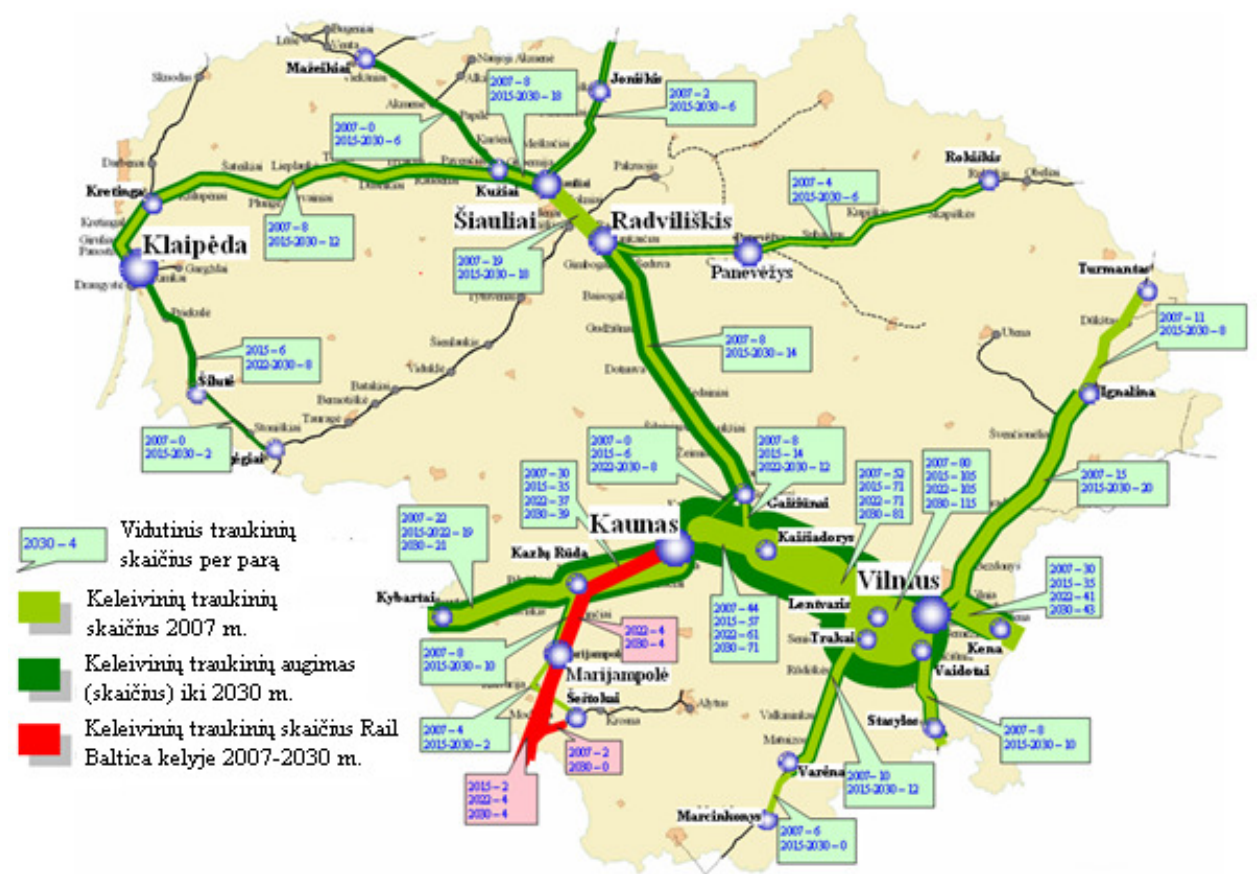

2.1 pav. Keleivinių traukinių skaičius $2007-2030 \mathrm{~m}$.

$\mathrm{AB}$ „Lietuvos geležinkeliai“ linijose

Fig. 2.1. Number of passenger trains in the JSC

"Lithuanian Railways" lines in 2007-2030

Didžiausi keleivių srautai yra maršrutuose Vilnius-Kaunas, KaunasKlaipèda, Vilnius-Turmantas.

Skyriaus tematika paskelbtas disertacijos autoriaus straipsnis (Dailydka, Lingaitis 2009).

\subsection{Keleivių vežimo vietiniais maršrutais analizè}

2006-2009 m. vietinio susisiekimo geležinkelių maršrutais Lietuvoje keleivių vežta vidutiniškai po 4,2 mln. kasmet. Vidutinè traukinių rida vietinio susisiekimo maršrutais buvo 4,4 mln. km kasmet. Kaip kito vežtų keleivių skaičius ir transporto priemonių nuvažiuota rida per pastaruosius ketverius metus, pateikta 2.2 pav. Rida $2006-2009$ m. padidejo 23 proc., keleivių skaičius per šį laikotarpi sumažejo 32 proc. Tai rodo, kad esamos transporto priemonès naudojamos neracionaliai, traukiniai važinèja nepilni. 


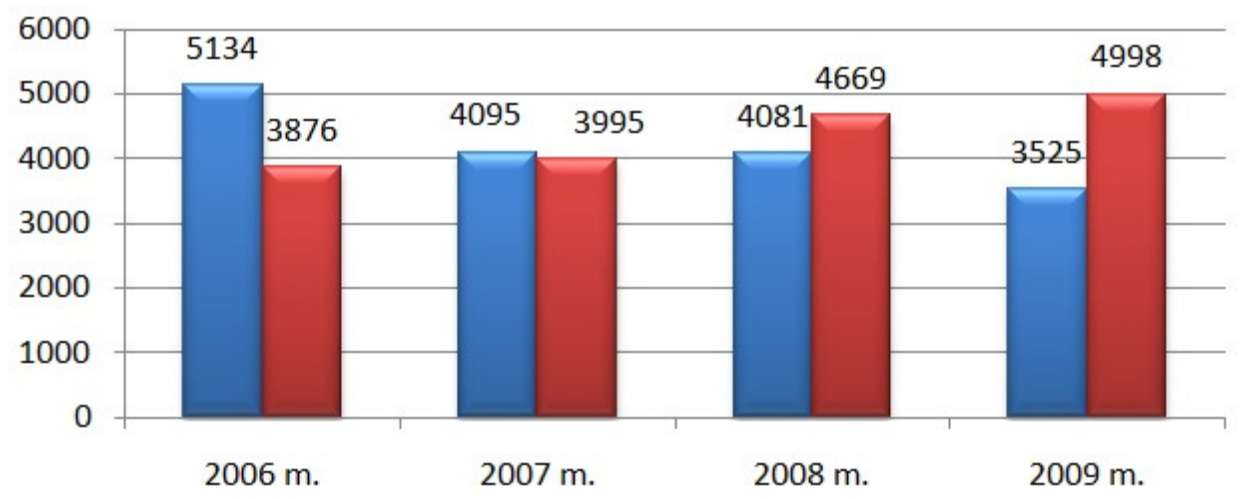

\eleivių skaičius, tūkst. $\quad$ Rida, tūkst. km

2.2 pav. Keleivių skaičiaus ir ridos kaita 2006-2009 m.

Fig. 2.2. Passenger number and mileage change during the year 2006-2009

2.1 lentelëje pateikti duomenys, kiek procentų pajamų, gautų už parduotus bilietus, trūksta, kad būtų padengtos sąnaudos. Pajamos, gautos už bilietus, vidutiniškai padengia tik 14 proc. vežèjų patirtų išlaidų. Pajamos už bilietus šiuo laikotarpiu kito nedaug, tačiau sąnaudos kasmet augo ir nuo 2006 m. padidèjo 30 proc. Trūkumas sąnaudoms padengti taip pat augo.

2.1 lentelè. Vietinio keleivinio geležinkelių transporto pajamų už bilietus ir išlaidų santykis 2006-2009 m.

Table 2.1. Income for the tickets and expenses ratio at the local rail passenger transport in 2006-2009

\begin{tabular}{|c|c|c|c|c|c|}
\hline Metai & $\begin{array}{c}\text { Pajamos už } \\
\text { bilietus, } \\
\text { tūkst. Lt }\end{array}$ & $\begin{array}{c}\text { Sąnaudos, } \\
\text { tūkst. Lt }\end{array}$ & $\begin{array}{c}\text { Pajamų dalis, } \\
\text { dengianti } \\
\text { sąnaudas, \% }\end{array}$ & $\begin{array}{c}\text { Trūkumas } \\
\text { sąnaudoms } \\
\text { padengti, tūkst. Lt }\end{array}$ & $\begin{array}{c}\text { Trūkumas, } \\
\%\end{array}$ \\
\hline 2006 & 18054,6 & 121053,9 & 14,9 & 102999,3 & 85,1 \\
\hline 2007 & 20597,5 & 136955,1 & 15,0 & 116357,6 & 85,0 \\
\hline 2008 & 22501,1 & 176093,4 & 12,8 & 153592,3 & 87,2 \\
\hline 2009 & 21548,9 & 177094,9 & 12,2 & 155546,0 & 87,8 \\
\hline
\end{tabular}

Didžiausias trūkumas pastebimas 2009 m., kai padidèjo iki $155 \mathrm{mln}$. Lt, arba 87,8 proc. 
Trūkstamos sąnaudos padengiamos dviem pajamų tipais. Pirmasis - tai kompensacijos už teisę i lengvatas turinčių keleivių vežimą, kai vežèjams kompensuojama pati lengvata. Antrasis, kai dotacijos kaip pajamos su kompensacijomis nepadengia vežèjų išlaidų, nes net ir visa nustatyta vežimų kaina nepadengia išlaidų. Dotacijų poreikiui nustatyti svarbu palyginti pajamas su priskaičiuotomis kompensacijomis ir sąnaudas (2.2 lentelèje).

2.2 lentelè. Pajamų už bilietus su priskaičiuotomis kompensacijomis ir išlaidų santykis 2006-2009 metais (be PVM)

Table 2.2. Income for the tickets with accrued compensation and expenses ratio for 2006-2009 (excluding VAT)

\begin{tabular}{|c|c|c|c|c|c|}
\hline Metai & $\begin{array}{c}\text { Pajamos už bilietus su } \\
\text { priskaičiuotomis } \\
\text { kompensacijomis, } \\
\text { tūkst. Lt }\end{array}$ & $\begin{array}{c}\text { Sānaudos, } \\
\text { tūkst. Lt }\end{array}$ & $\begin{array}{c}\text { Pajamú dalis, } \\
\text { dengianti } \\
\text { sanaudas, \% }\end{array}$ & $\begin{array}{c}\text { Trūkumas } \\
\text { sanaudoms } \\
\text { padengti }\end{array}$ & $\begin{array}{c}\text { Trūkumas, } \\
\%\end{array}$ \\
\hline 2006 & 22054,6 & 121053,9 & 18,2 & 98999,3 & 81,8 \\
\hline 2007 & 25097,5 & 136955,1 & 18,3 & 111857,6 & 81,7 \\
\hline 2008 & 27701,1 & 176093,4 & 15,7 & 148392,3 & 84,3 \\
\hline 2009 & 27648,9 & 177094,9 & 15,6 & 149446 & 84,4 \\
\hline
\end{tabular}

Iš vietinio susisiekimo geležinkeliais maršrutų $\mathrm{AB}$,Lietuvos geležinkeliai“ vidutiniškai kasmet gauna 25,6 mln. Lt sąlyginių pajamų, kurias sudaro pajamos už parduotus bilietus ir priskaičiuotos kompensacijos už lengvatinius bilietus.

Vietinio susisiekimo maršrutuose imonè vidutiniškai patiria $152,8 \mathrm{mln}$. Lt išlaidų. Ypač išlaidos didejo buvo 2007-2008 m. Daugiausia tai lèmé degalų kainos ir darbo užmokestis, kai augo šalies ekonomika. Išlaidų didejjimą taip pat paveikè investicijos i infrastruktūrą ir didejantys amortizaciniai atskaitymai, taip pat vidinès apskaitos pokyčiai, kai imtas skaičiuoti keleivių vežimo infrastruktūros mokestis. Ridai padidejus 23 proc., sąnaudos išaugo 30 proc. Vertinant ketverius metus, vidutiniškai kasmet trūksta net $127 \mathrm{mln}$. Lt (arba 83,2 proc.) vežèjų sąnaudoms padengti (2.3 pav.).

Negautos pajamos iš keleivių dèl lengvatų maršrutuose yra kompensuojamos. Priskaičiuotos kompensacijos 2006 ir 2008 m. buvo visiškai apmokètos (2.3 lentelè). 


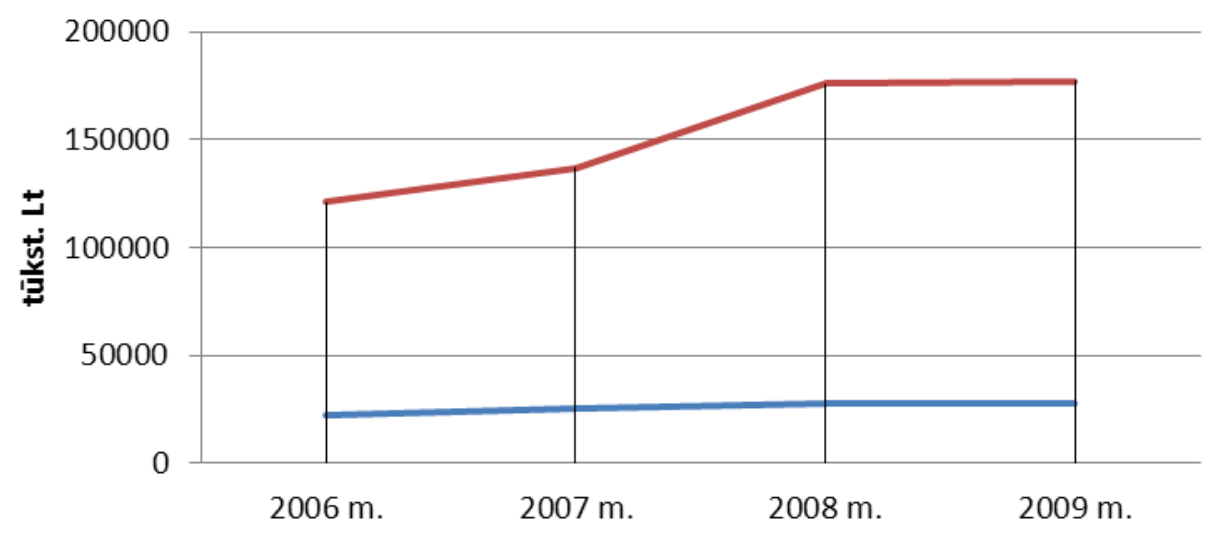

— Pajamos už bilietus su priskaičiuotomis kompensacijomis, tūkst. Lt —Sąnaudos, tūkst. Lt

2.3 pav. Vietinio susisiekimo maršrutu geležinkeliais pajamos už bilietus su priskaičiuotomis kompensacijomis ir sąnaudos, tūkst. Lt

Fig. 2.3. Income for the tickets with accrued compensation and expenses at the local rail passenger transport

2.3 lentelè. Priskaičiuotos ir gautos kompensacijos 2006-2009 m. (be PVM)

Table 2.3. Accrued and received compensation for the period 2006-2009 (excluding VAT)

\begin{tabular}{|c|c|c|c|c|}
\hline Metai & $\begin{array}{c}\text { Kompensacijų } \\
\text { poreikis, tūkst. Lt }\end{array}$ & $\begin{array}{c}\text { Gautos } \\
\text { kompensacijos, } \\
\text { tūkst. Lt }\end{array}$ & $\begin{array}{c}\text { Kompensacijų } \\
\text { trūkumas, } \\
\text { tūkst. Lt }\end{array}$ & Trūkumas, \% \\
\hline 2006 & 4250,0 & 4250,0 & 0,0 & 0,0 \\
\hline 2007 & 4500,0 & 4300,0 & 200,0 & 4,4 \\
\hline 2008 & 5200,0 & 5200,0 & 0,0 & 0,0 \\
\hline 2009 & 6100,0 & 3900,0 & 2200,0 & 36,1 \\
\hline
\end{tabular}

Nuo 2006 m. kompensacijų poreikis kasmet didejjo 10-12 proc. Kritiniai metai buvo 2009-ieji, kai kompensacijų trūkumas pasiekè 36,1 proc., nes nebuvo apmokèta apie 2,2 $\mathrm{mln}$. Lt.

Priskaičiuotos ir gautos dotacijos 2006-2009 m. pateiktos 2.4 lentelèje. 
2.4 lentelè. Priskaičiuotos ir gautos dotacijos 2006-2009 m. (be PVM)

Table 2.4. Accrued and received a grant in the period 2006-2009 (excluding VAT)

\begin{tabular}{|c|c|c|c|}
\hline Metai & $\begin{array}{c}\text { Dotaciju poreikis, } \\
\text { tūkst. Lt }\end{array}$ & $\begin{array}{c}\text { Gautos dotacijos, } \\
\text { tūkst. Lt }\end{array}$ & $\begin{array}{c}\text { Dotacijų trūkumas, } \\
\text { tūkst. Lt }\end{array}$ \\
\hline 2006 & 98999,3 & 4930,0 & 94069,3 \\
\hline 2007 & 111857,6 & 14930,0 & 96927,6 \\
\hline 2008 & 148392,3 & 25930,0 & 122462,3 \\
\hline 2009 & 149446,0 & 437,9 & 149008,1 \\
\hline
\end{tabular}

Dotacijų poreikis 2006-2009 m. nuolat didejo ir 2008-2009 m. buvo didžiausias, kai siekè atitinkamai $148,4 \mathrm{mln}$. Lt ir $150 \mathrm{mln}$. Lt.

Vidutiniškai kiekvienais metais dotacijų trūkumas sieke 104,7 mln. Lt. Didžiausias trūkumas buvo 2009 m., kai skirtumas tarp priskaičiuotų ir gautų dotacijų buvo net 99,7 proc., vadinasi, nebuvo apmoketa net 150,8 mln. Lt priskaičiuotu dotacijų.

Vidutiniai metiniai pajamų lūkesčiai sąnaudoms padengti ir faktinès pajamos pateiktos 2.4 pav.

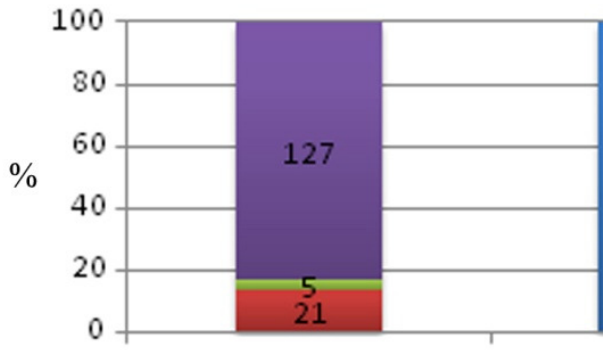

pajamụ lūkestis

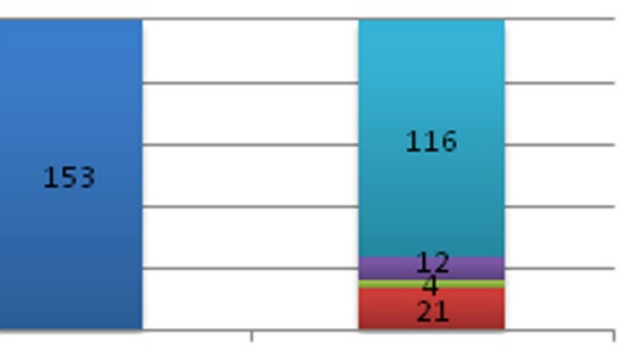

sąnaudos pajamų faktas

pajamos už bilietus $\quad$ kompensacijos $\square$ dotacijos $\square$ nepadengtos sąnaudos

2.4 pav. Vidutiniai metiniai pajamų lūkesčiai sąnaudoms padengti ir faktinès pajamos, mln. Lt

Fig. 2.4. The average annual income expectations and the actual costs, mill. LTL

Skaičiuojant vienam traukinio kilometrui, vidutinès sąnaudos 2006-2009 m. siekia 34,67 Lt, pajamos padengia 4,74 Lt, kompensacijos - 0,99 Lt, dotacijos 2,66 Lt. Net 26,29 Lt kilometro išlaidų lieka nepadengtos (2.5 pav.). 


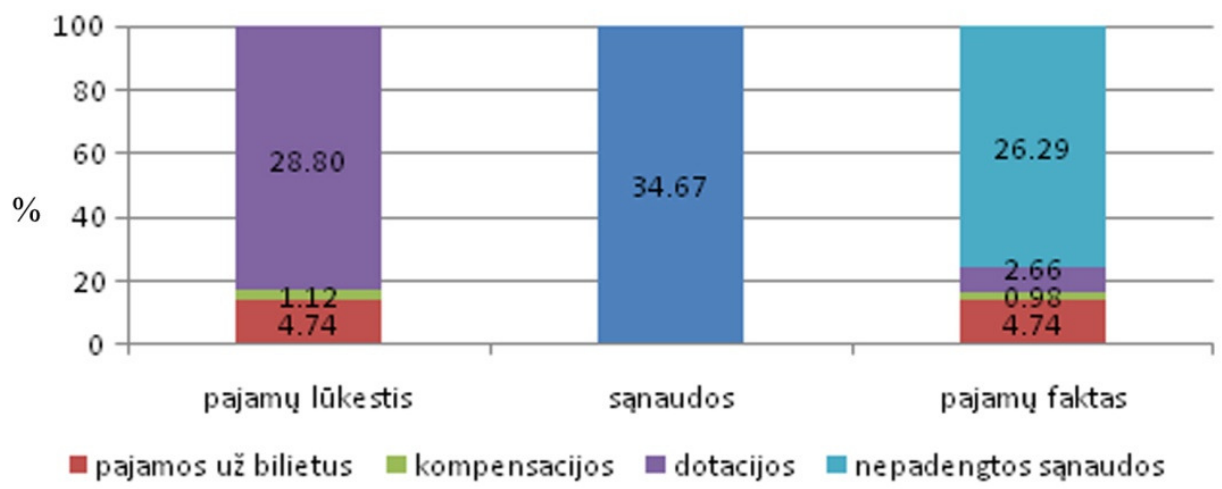

2.5 pav. Vidutiniai metiniai pajamų lūkesčiai sąnaudoms padengti ir faktinès pajamos, $\mathrm{Lt} / \mathrm{trauk}$. $\mathrm{km}$

Fig. 2.5. The average annual income expectations and the actual costs, LTL/train $\mathrm{km}$

Lyginant su kitomis pasaulio šalimis, matyti (1.1 lentelè), kad Vakarų valstybès suteikia nemažų kompensacijų keleivių vežimui geležinkeliais. 2001$2002 \mathrm{~m}$. duomenimis, daugiausia kompensuota Kanados valstybinei įmonei „VIARAK“ - 13,8 euro cento 1 keleivio kilometrui, toliau eina JAV, Vokietija, Prancūzija, o privačios Didžiosios Britanijos imonèms kompensuota 4,5 euro cento 1 keleivio kilometrui.

Toliau sprendžiant keleivių vežimo nuostolių mažinimo klausimus, įdomu palyginti anksčiau minètų šalių kompensacijas 1 keleivio $\mathrm{km}$ su valstybinèmis kompensacijomis Lietuvoje. Per paskutinius ketverius metus, t. y. 20062009 m., Lietuvos geležinkeliai už keleivių vežimą gavo dotacijų atitinkamai 8922,0 tūkst. Lt, 19052,2 tūkst. Lt, 30977,6 tūkst. Lt ir 4290,9 tūkst. Lt.

Nuvažiuota keleivių km per šiuos metus atitinkamai 430,5 mln. kel. km, 408,7 mln. kel. km, 397,5 mln. kel. km ir 356,9 mln. kel. km.

Grafiškai valstybès dotacijų (su kompensacijomis už negautas pajamas) rodikliai pavaizduoti 2.6 pav.

Pažymètina, kad iki 2008 m. šie rodikliai šiek tiek augo, tačiau 2009 m. dèl ekonomikos nuosmukio smarkiai sumažèjo. Palyginus su kitų Vakarų šalių teikiamomis kompensacijomis keleiviams vežti, matyti, kad JAV jos vidutiniškai didesnès apie 10 kartu, Kanadoje - apie 12, Vokietijoje - apie 5, Didžiojoje Britanijoje - apie 4 ir Prancūzijoje - daugiau kaip 2 kartus. 


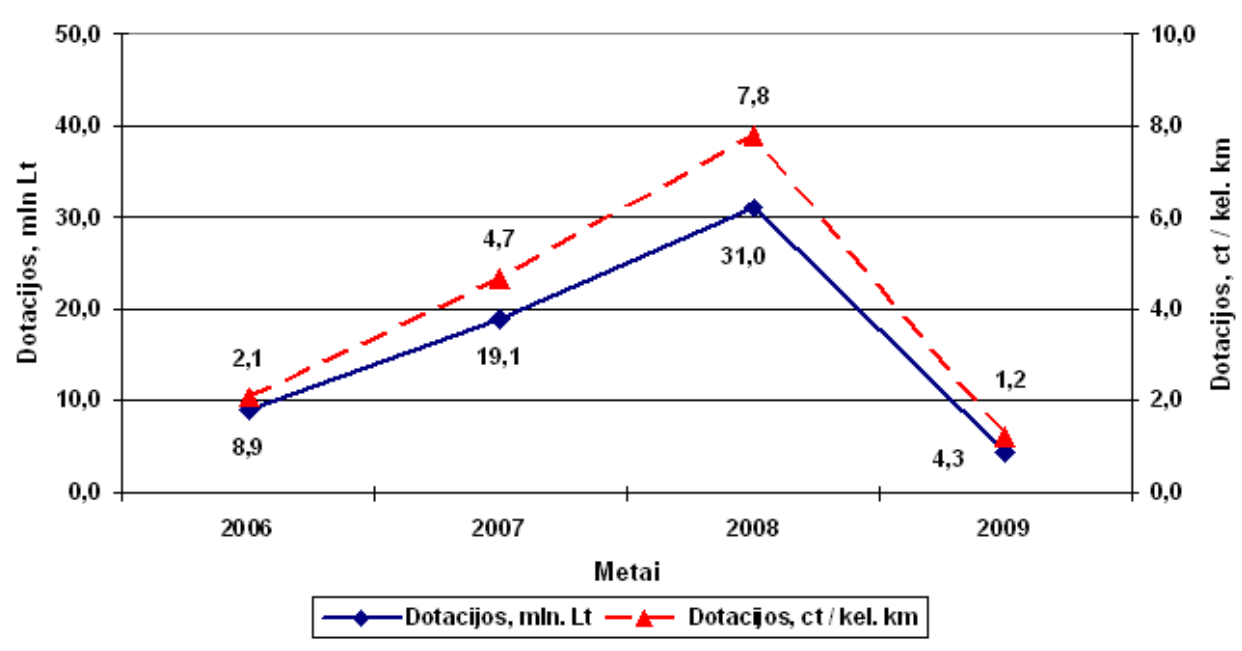

2.6 pav. Valstybės dotacijų (su kompensacijomis) rodikliai

Fig. 2.6. Government grants (with compensation) rates

Suprantama, tiesiogiai lyginti Lietuvoje gaunamas dotacijas su kitomis valstybėmis nèra korektiška, nes skiriasi tinklo struktūra, priemonès, kuriomis vežami keleiviai, be to, jų valdymas nèra identiškas (valstybinès ir privačios), keleivių aptarnavimas ir kiti veiksniai, lemiantys sistemų neadekvatumą. Tačiau aiškiai matyti ir tai, kad iki šiol paprastas negreitaeigis keleivinis geležinkelių transportas be dotacijų niekur neišsilaiko. Taigi būtina ieškoti vidinių rezervų organizacinių ir techninių priemonių keleivių vežimo geležinkeliais nuostoliams mažinti. Šis darbas ir skiriamas minètiems tikslams pasiekti, t. y. racionaliems sąstatams parinkti ir keleivių komfortui gerinti.

\subsection{Pagrindinès problemos keleivių vežimo sektoriuje}

Veiksniai, sukeliantys tam tikrų problemų vežant keleivius Lietuvos geležinkeliais, yra šie:

- tolesnè Lietuvos visuomenès automobilizacija. Augant šalies gyventojų pragyvenimo lygiui, nuolat dideja gyventojų dalis, galinti įsigyti nuosavą automobili. Iki $2009 \mathrm{~m}$. kasmet privačiu automobilių Lietuvoje daugejo 5 proc. ir daugiau. Kiekvienas, turintis nuosavą automobili, daugiau linkęs naudotis šia transporto priemone, o ne visuomeniniu transportu; 
- šiuolaikiškų keleivinių riedmenų trūkumas. Nuo 1990 iki 2008 m. dèl lèšų trūkumo AB „Lietuvos geležinkeliai“ keleivinių riedmenų parko atnaujinimas buvo nepakankamas. Eksploatacijai tinkamų keleivinių riedmenų trūkumas, dažni eksploatuojamų riedmenų gedimai, brangi jų eksploatacija - viena iš priežasčių, dèl ko buvo gerokai sumažintas maršrutu/reisų skaičius;

- keleivinių traukinių eismo ribojimai dèl darbų, vykdomų igyvendinant reikšmingus viešosios geležinkelių infrastruktūros modernizavimo projektus. Todèl vykdant rekonstrukcija, būtina kartu su kelio darbais organizuoti traukinių eismą taip, kad būtų užtikrintas prekinių bei keleivinių (bent jau svarbiausių) traukinių praleidimas;

- prasta geležinkelių infrastruktūra, jungianti Lietuvos geležinkelių tinklą su Lenkijos geležinkelių tinklu. Iki „Rail Baltica“ nutiesimo AB „Lietuvos geležinkeliai“" planuoja atnaujinti keleivių vežimą Lenkijos kryptimi, naudodama modernią ir patikimą věžès keitimo įrangą. Šis projektas strigo dèl įvairių priežasčių.

Veiksniai, lemiantys keleivių, važiuojančių geležinkeliais, tam tikrą didèjimą:

- didejjančios grūstys automobilių keliuose, avaringumas. Didèjant eismo intensyvumui automobilių keliuose, traukinys suteiks galimybę išvengti grūsčių ir vèlavimų bei avarijų rizikos keleiviui. Reali automobilių grūsčiu problema artimiausioje perspektyvoje (per 3-5 metus) tiketina prieigose prie didžiausių Lietuvos miestų (visų pirma Vilniaus ir Kauno);

- pasaulinis degalų ir kitų energinių išteklių kainų augimas, akcizų didinimas. Degaluz kaina - svarbiausias veiksnys, lemiantis keliones autotransporto priemonemis. Perspektyvoje plètojant Lietuvos geležinkeliuose kontaktinį elektros tinklą traukinių pranašumas prieš autotransportą Lietuvoje didès;

- valstybinis reguliavimas ar jo pokyčiai, palankūs keleivių vežimo geležinkeliais veikai plettoti.

\subsection{Keleivių vežimo perspektyvos}

Prognozuojama, kad iki 2015 m. (2.7 pav.) keleivių daugès daugiausia dèl naujų reisų isteigimo (atnaujinimo) ir tankinimo.

Keleivinių riedmenų parko atnaujinimas ir geležinkelių infrastruktūros modernizavimas - ilgalaikiai procesai, todèl staigūs pokyčiai gerinant keleivių vežimo kokybę (didinant greiti, kelionès komforta) negalimi. 


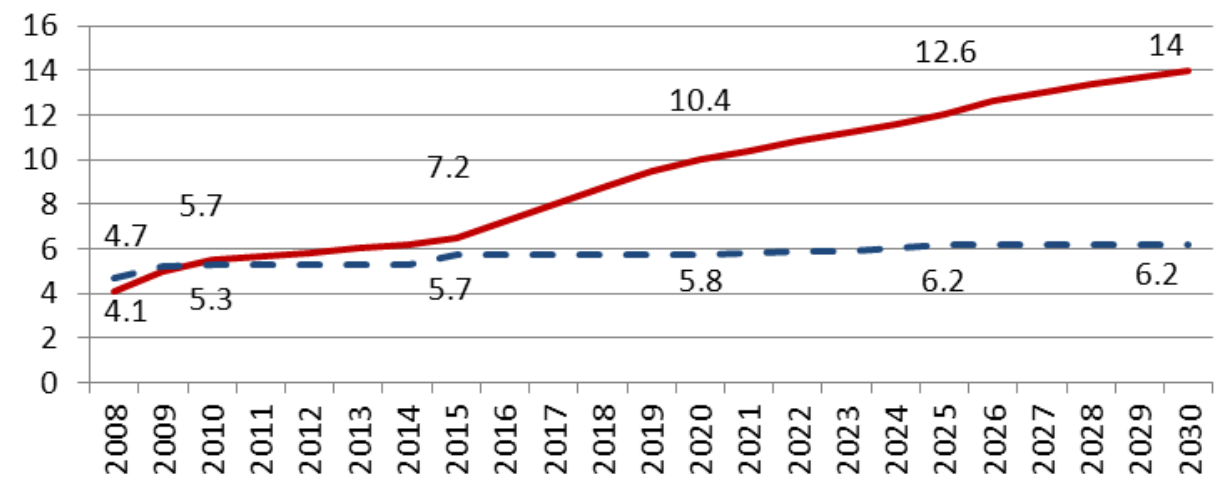

Keleivių skaičius, mln. - - Traukinio kilometrų skaičius, mln. km

Metai

2.7 pav. AB „Lietuvos geležinkeliai“ vietinio susisiekimo keliais vežamų keleivių skaičius $2008-2030 \mathrm{~m}$.

Fig. 2.7. Number of passengers at the JSC "Lithuanian Railways" local rail passenger transport 2008-2030

Žymus keleivių, vykstančių vietiniais geležinkelio maršrutais, skaičiaus padidèjimas AB „Lietuvos geležinkeliai“ strategijoje numatomas po 2015 metų. Tai lems: atnaujintas keleivinių riedmenų parkas; atskirų ruožų elektrifikavimas, idiegta moderni bilietų rezervavimo ir pardavimo sistema; padidejusios grūstys automobilių keliuose; išaugusi degalų kaina; valstybès transporto politika, skatinanti keliones traukiniu; geležinkelio ruožu Vilnius-Kaunas (vèliau Kaišiadorys-Šiauliai, Šiauliai-Klaipeda) modernizavimas, kurią igyvendinus bus didinamas keleivinių traukinių leistinas greitis šiuose maršrutuose (iki $160 \mathrm{~km} / \mathrm{h}$ ) bei visų ruožų elektrifikavimas.

Siekiant gerinti tarptautinio susisiekimo sąlygas, numatoma plètoti keleiviu vežimą $A B$ „Lietuvos geležinkeliai“ formavimo tarptautiniais traukiniais: rytų kryptimi ir šiaurès-pietų kryptimi.

$\mathrm{AB}$ „Lietuvos geležinkeliai“ formavimo tarptautiniai traukiniai dèl rinkos specifikos (t. y. palyginti mažų keleivių vežimo ikainių ir mažų vežimo apimčių) yra nuostolingi (2008-2009 m. nuostolis viršijo $30 \mathrm{mln}$. Lt) ir nèra galimybių investicijomis ar kitomis priemonemis užtikrinti šios veiklos nenuostolingumą (bent jau artimu laikotarpiu). Šiai veiklai vykdyti ir plètoti būtinos valstybès dotacijos.

Tarptautiniais maršrutais prognozuojama keleivių vežimo apimčių dinamika pateikta 2.8 pav. Tikimasi, kad tarptautiniais maršrutais vykstančių keleivių skaičius padidès nuo 1,0 mln. keleivių (2008 m.) iki $3 \mathrm{mln}$. keleivių $(2030 \mathrm{~m}$.). 
Mln. keleivių

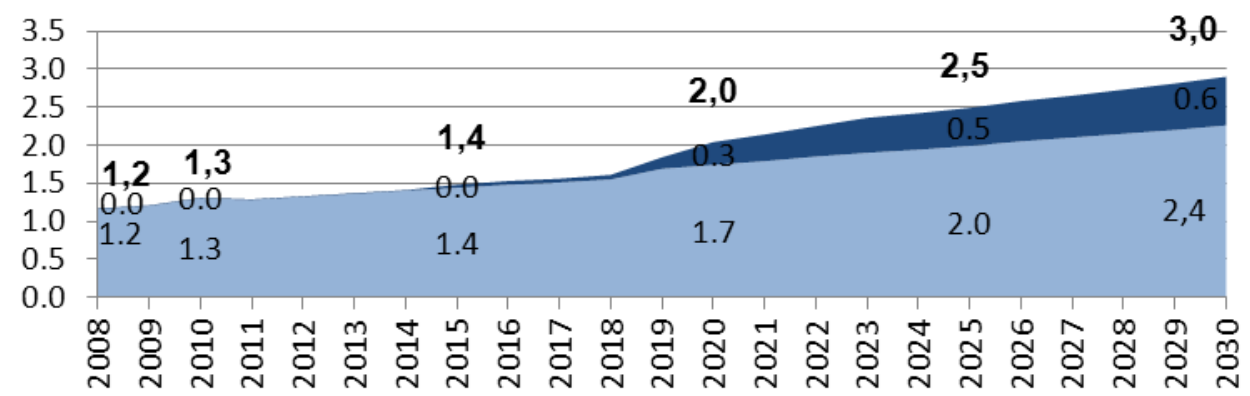

Metai

Keleivių skaičius 1435 mm pločio vèžès ruože į Lenkiją

2.8 pav. AB „Lietuvos geležinkeliai“ tarptautiniais maršrutais vežamų keleivių skaičius 2008-2030 m.

Fig. 2.8. Number of passengers at the JSC "Lithuanian Railways" international rail passenger transport 2008-2030

Reikšmingo keleivių apimčių augimo tikimasi nutiesus „Rail Baltica“ europinę vėžę iki Kauno keleivių stoties (nuo 2018 m.), kai bus pagerintos keleivių vežimo I koridoriumi sąlygos.

\subsection{Pagrindiniai uždaviniai, keliami keleivių vežimo sektoriui}

Pirmiausia būtina atlikti šiuos darbus:

1. Užtikrinti pajègumus, reikalingus keleivių vežimo veiklai plètoti: pakankamą geležinkelių infrastruktūros pralaidumą ir pakankamą keleivinių riedmenų parką.

2. Užtikrinti paslaugų kokybės atitikti klientų poreikiams, padidinti paslaugu prieinamumą. Keleivių vežimo veiklos orientacija i kliento poreikius - vienintelis būdas padidinti geležinkelių vežèjo patrauklumą ir pritraukti klientus. Orientuojantis i klientų poreikius, bus plètojamos paslaugos turistiniams maršrutams.

3. Padidinti veiklos efektyvumą (minimizuoti veiklos sąnaudas). Keleivių vežimo veiklos nuostolio sumažinimas - būtina sąlyga šios veiklos tęstinumui bendrovèje. 
Pagrindinès keleivių vežimo ūkio modernizavimo ir plètros kryptys: elektrinių traukinių parko atnaujinimas; dyzelinių traukinių parko atnaujinimas; keleivinių vagonų parko atnaujinimas; keleivinių lokomotyvų parko atnaujinimas; keleivinių riedmenų įsigijimas maršrutams Lenkijos („Rail Baltica“) kryptimi.

2010-2020 m. numatoma atnaujinti visą bendrovès keleivinių vagonų parką, nusidèvejjusius vagonus pakeičiant naujais ar modernizuotais.

Optimizavus keleivinių vagonų naudojimą, keleivinių vagonų poreikis sumažès.

\title{
2.5. Investiciju poreikis
}

AB „Lietuvos geležinkeliai“ investicijų poreikis (Dailydka, Lingaitis 2009) keleivių vežimo veiklai plètoti parodytas 2.9 pav.

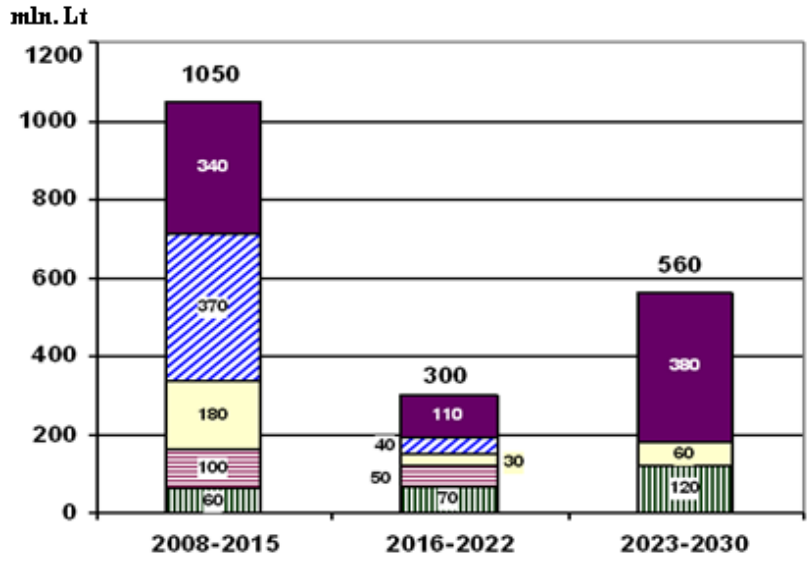

\author{
口 Elektriniч traukiniч isigyjimas \\ Dyzeliniu traukiniu (automotrisiu) \\ jsigyjimas ir modernizavimas \\ $\square$ Keleiviniy vagony isigyjimas ir \\ modernizavimas \\ Riedmenys 1435 mun vèžei \\ Kiti projektai (riedmeny remonto \\ techuologija, biliety pardavimo \\ tobulinimas ir kt.)
}

2.9 pav. Preliminarus AB „Lietuvos geležinkeliai“ investicijų poreikis keleiviniam transportui 2008-2030 m.

Fig. 2.9. Preliminary JSC „Lithuanian Railways” investment demand for passenger transport in 2008-2030

Pagal lèšų poreikio investicijoms pasiskirstymą pagal metus didžiausias lèšų poreikis bus 2008-2015 m. Šiuo laikotarpiu nusidèvès didžioji dalis AB „Lietuvos geležinkeliai“" keleivinių riedmenų (elektrinių, dyzelinių traukinių, keleivinių vagonų bei keleivinių šilumvežių, eksploatuotų iki 2007 m.), kurie bus keičiami naujais ar modernizuotais.

Planuojama, kad naudojant investicijas, rinkodara, optimalų transporto priemonių pirkima, gerą aptarnavima, kelionès geležinkeliu komforto bei kito- 
mis veiklos optimizavimo priemonėmis padidinus keleivių skaičių, šios veiklos nuostolingumas ilgalaikejje perspektyvoje bus sumažintas.

Preliminariais skaičiavimais po keleivių vežimo veiklos plètros ir atnaujinimo nuostoliai gali būti sumažinti 2-3 kartus (nuo $150 \mathrm{mln}$. Lt iki 50-70 mln. $\mathrm{Lt})$, taip pat sumažès valstybès finansavimo poreikis.

\subsection{Keleivių vežimas Lietuvoje pagal atskiras transporto rūšis}

Pastaruoju metu keleiviams vežti visame pasaulyje naudojamos šios pagrindinès transporto rūšys: automobilių, geležinkelių, vandens ir oro. Gana dažnai naudojamas mišrusis transportas, kai derinamos kelios transporto rūšys. Pavyzdžiui, oro ir automobilių, geležinkelių ir vandens (jūrų) ir panašiai, t. y. atskiros transporto rūšys sujungiamos į vieną transporto sistemą.

Keleiviu srautų kitimas Lietuvoje per paskutinius metus pagal įvairias transporto rūšis pateiktas 2.10 pav.

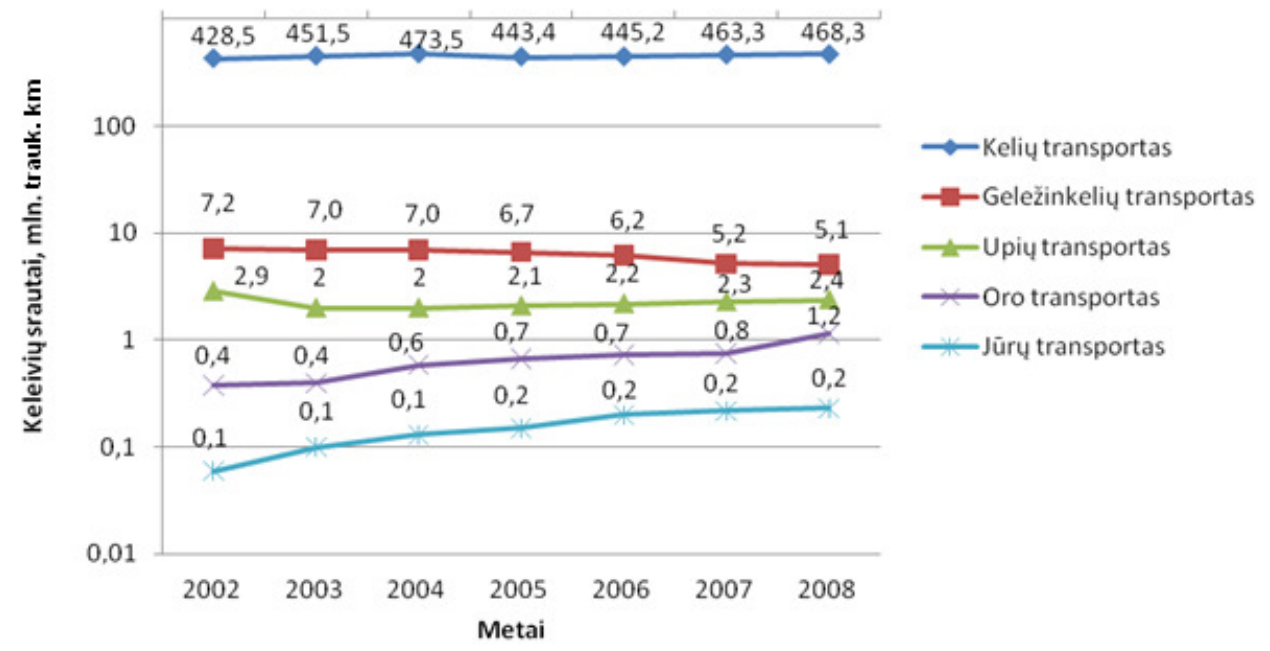

2.10 pav. Keleivių srautų kitimas pagal ịvairias transporto rūšis

Fig. 2.10. Passenger flow change in different modes

Paveiksle aiškiai matyti, kad daugiausia keleivių Lietuvoje vežama kelių transportu. Transporto srautai Lietuvos magistraliniais keliais ir miestų gatvėmis nuolat didejja, grūstys miestuose tampa viena iš eismo saugumo grèsmių. 20082009 m. statistiniai duomenys (eismo ivvykiuose žuvusiujų skaičius, tenkantis 
1 mln. gyventoju) rodo, kad Lietuva tarp ES šalių yra šeštoje vietoje nuo galo pagal avaringumą ir žuvusiujų keliuose skaičių. Kai kuriuose keliuose eismo intensyvumas yra daugiau kaip 30000 automobiliu per parą. Padidejo eismo greitis, automobilių ašių apkrovos. Atsirado rimtų problemų dèl transporto grūsčių, kurias sukèlè asmeninių automobilių pagausèjimas ir padidejusios vežimų apimtys. Kiekvienais metais Lietuvoje registruojama apie 6000 eismo ivvykiu, kuriuose žūva ar sužalojami žmonès. Dar daugiau eismo ìvykių, kai apgadinamos kelių transporto priemonès, transporto infrastruktūros objektai, padaroma žalos aplinkai.

Saugaus eismo padètis Lietuvoje sudètinga, nors pastaruoju metu gerejja. 2009 m. Lietuvoje ivyko 3827 eismo įvykiai, kuriuose žuvo 370, buvo sužeista 4459 žmonès. Svarbiausios priežastys - eismo dalyvių neatsakingumas, neefektyvi eismo dalyvių kontrole keliuose, blogas eismo ir avarinių situacijų valdymas, informacijos keliautojui trūkumas, kuri lemia bendros kelių transporto informacinès infrastruktūros nebuvimas. Netiesioginiai ekonominiai nuostoliai dèl eismo įvykių šalies ūkiui kasmet sudaro apie 1,9 mlrd. Lt (Transporto ir kelių tyrimo instituto duomenys), t. y. apie $3 \%$ BVP (kitose Europos valstybèse šie nuostoliai sudaro apie 1-2\% BVP). Siekiant gerinti eismo saugumą Lietuvoje, nebepakanka taikyti tradicines priemones - gerinti kelio dangos kokybę, irengti skirtingų lygių sankryžas ar pan., nes šių priemonių veiksmingumas yra per mažas. Tačiau reikia pažymèti aiškų geležinkelių transporto pranašumą prieš automobilių transporta, nes dèl geležinkelių transporto kaltės per pastaruosius dešimt metų nežuvo nè vienas žmogus.

Geležinkelių transportu vežtų keleivių skaičius procentais nuo bendros transporto sistemos keleivių skaičiaus per paskutinius 8 metus parodytas 2.11 pav.

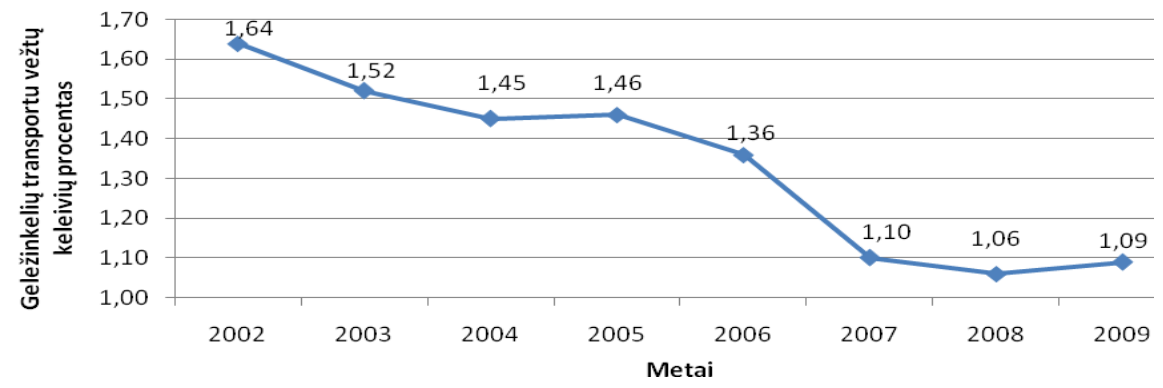

2.11 pav. Geležinkelių transportu vežtų keleivių skaičiaus procentas

Fig. 2.11. Percentage of number of passengers carried by railways 
Iš 2.11 pav. matyti, kad geležinkelių transportu vežtų keleivių skaičiaus procentas per paskutinius penkerius metus mažèjo. Tai lèmé didejjanti kelių transporto pasiūla ir kokybè.

Geležinkelių transportu vežtų keleivių skaičius per paskutinius 8 metus parodytas 2.12 pav.

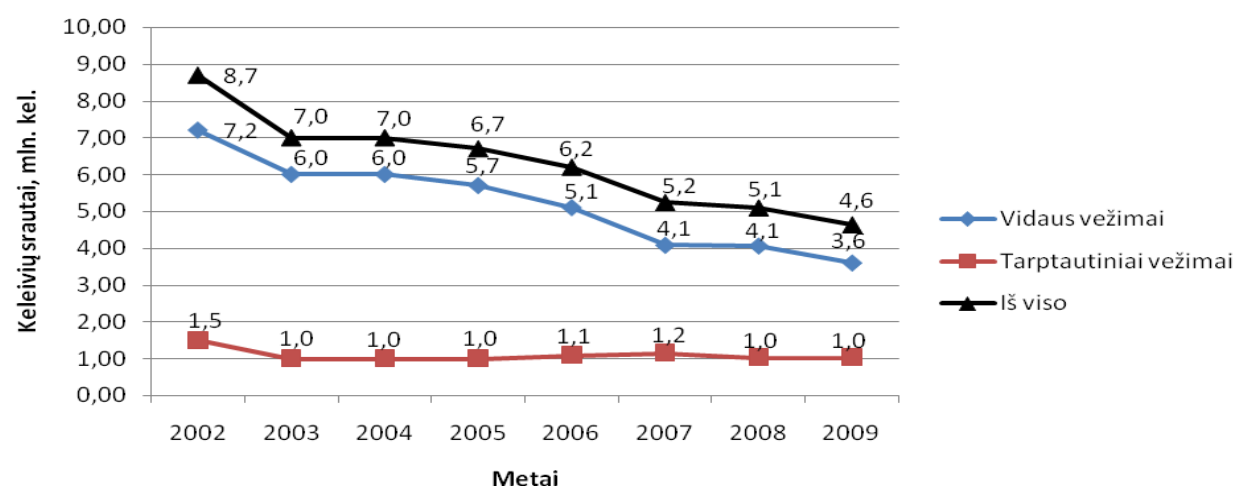

2.12 pav. Geležinkelių transportu vežtų keleivių skaičius

Fig. 2.12. Number of passengers carried by railways

Iš 2.12 pav. matyti, kad bendras geležinkelių transporto keleivių skaičius mažèja. Tai lėmè išorinès ir vidinès priežastys: išorinės priežastys - tai demografinès padèties kitimas (bendras gyventojų skaičiaus mažejjimas, gyventojų koncentracija miestuose), sparti automobilizacijos raida (didejjanti automobilių kelių transporto keleiviams vežti pasiūla ir kokybè bei kelių infrastruktūros kokybė); vidinès - nepakankamas susisiekimo greitis, komforto trūkumas (seni riedmenys, trūksta paslaugų, ne visur yra šiuolaikiškos stotys ir jų infrastruktūra), ne visada tinkami maršrutai, ne visada patogūs ir nepakankamai patikimi traukinių grafikai. Statistiškai ši mažèjimą iš esmès lemia mažèjančios vietinio vežimo apimtys, o tarptautinio vežimo apimtys stabilizuojasi. Jos stabilizuojasi, nes minètos mažèjimo priežastys ši vežimą mažiau veikia: mažesnè konkurencija su automobilių transportu, nes atstumai didesni ir juos iveikti automobiliu ar autobusu sunkoka, tarptautinių maršrutų keleiviai mažiau naudojasi infrastruktūra, todèl jiems ne taip svarbi stočių būklè, vietiniai maršrutai ar jų tvarkaraščiu patogumas bei patikimumas.

Geležinkelių transportu vežtų keleivių apyvarta keleivių kilometrais per paskutinius 8 metus parodyta 2.13 pav.

Analizuojant 2.13 pav. duomenis matyti, kad geležinkelių transportu vežtų keleivių apyvarta yra stabili (nors keleivių mažejja). Keleivių apyvarta keleivių kilometrais yra stabili, nes mažèjant keleivių, didèja vidutinis keleivio nuvažiuo- 
tas atstumas. Tai rodo tendenciją, kad dèl reto traukinių tankumo reise keleiviai trumpesniems ruožams renkasi automobilius, nors jiems kelionė kainuoja šiek tiek brangiau.

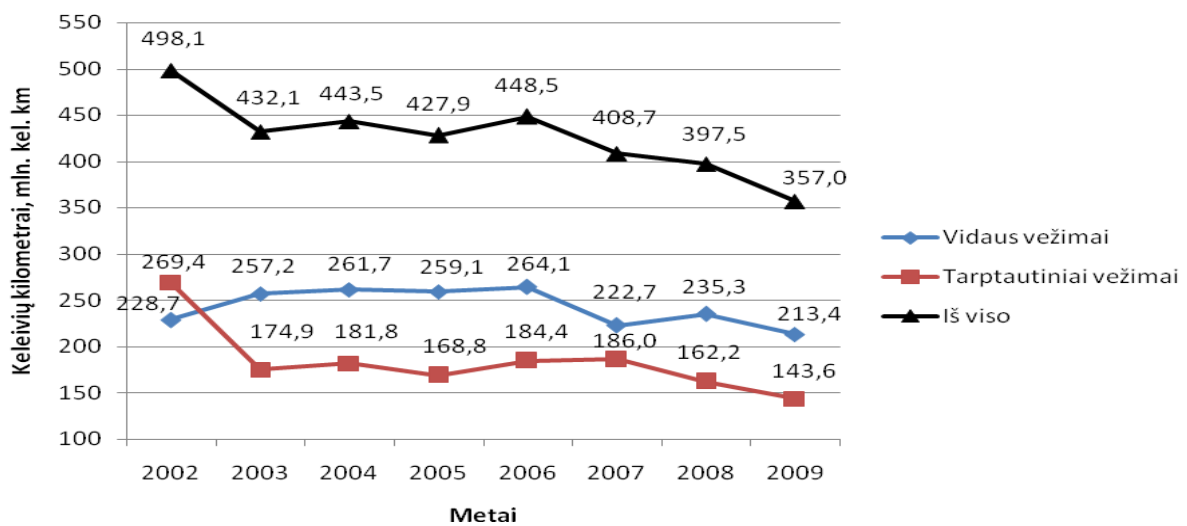

2.13 pav. Geležinkelių transportu vežtų keleivių apyvarta keleivių kilometrais Fig. 2.13. Turnover of passengers carried by railways in passenger-kilometres

Vidutinis keleivio nuvažiuotas atstumas geležinkeliais per pastaruosius 8 metus parodytas 2.14 pav.

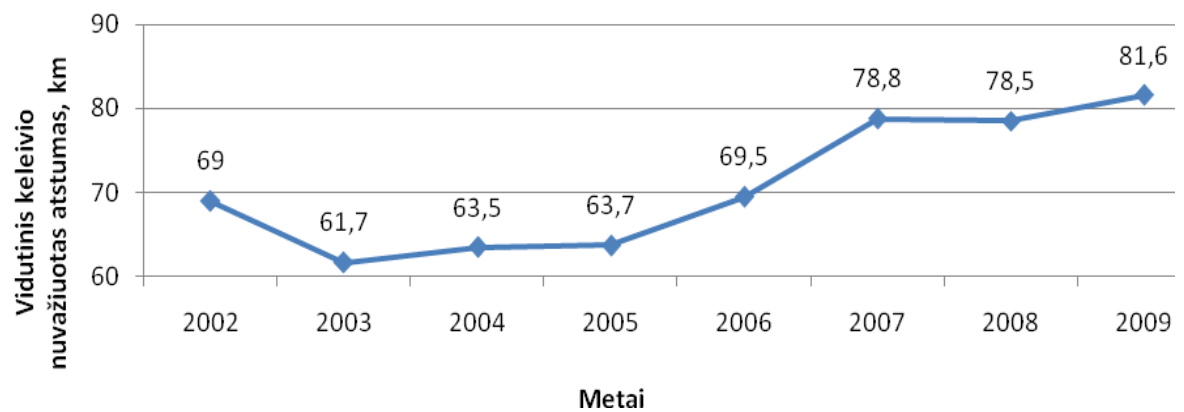

2.14 pav. Vidutinis keleivio nuvažiuotas atstumas geležinkeliais

Fig. 2.14. The average distance of one passenger traveled by railways

Iš 2.14 pav. matyti, kad vidutinis keleivio nuvažiuotas atstumas geležinkeliais pastaraisiais metais turi tendenciją didèti. Tai lemia tarptautinių vežimų didejjimas, o vietinių - mažejimas. Keleivių srautai bėgant metams kinta. Šis kitimas 2008-2009 m. pagal mènesius parodytas 2.15 pav. 


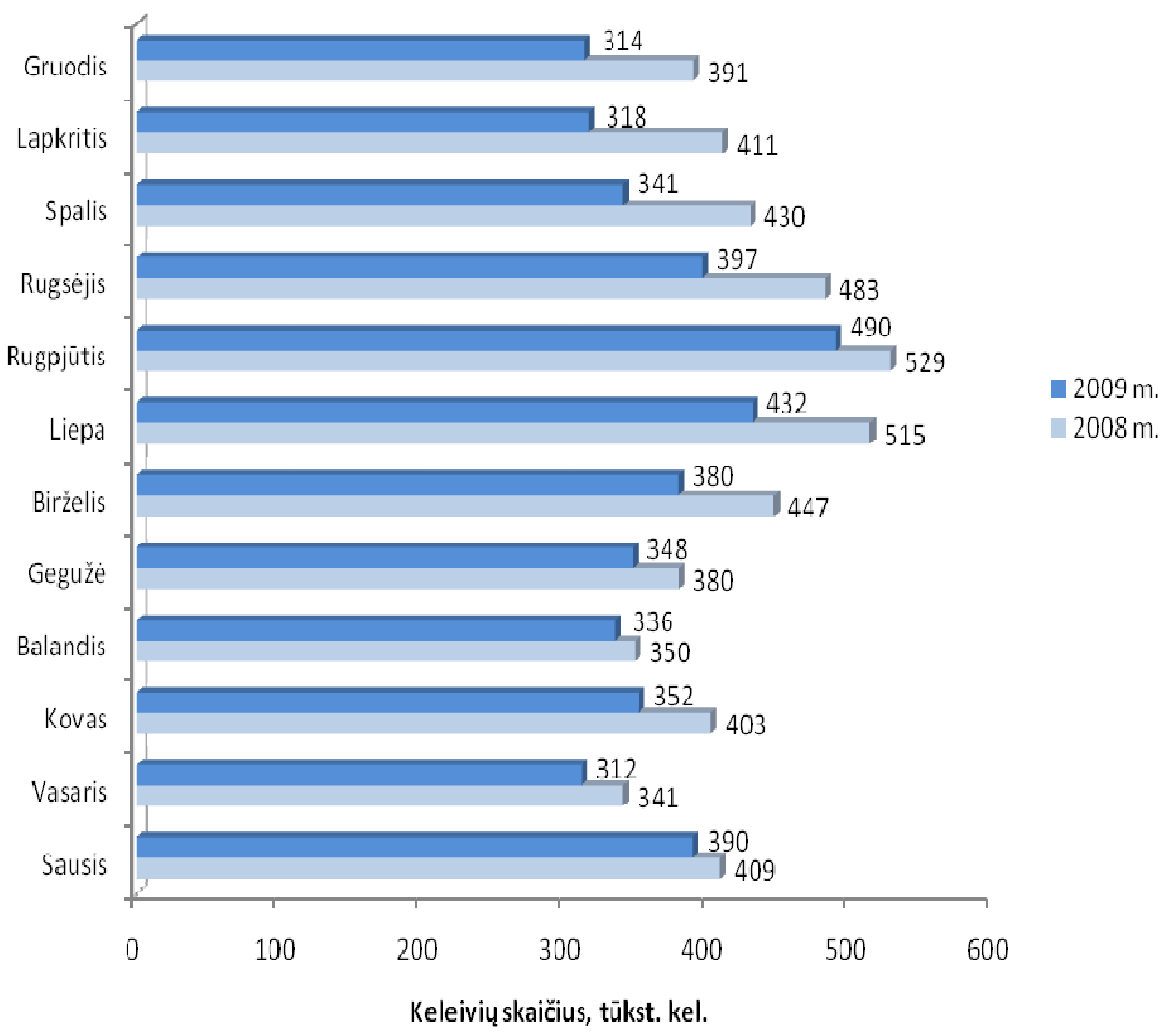

2.15 pav. Keleivių srautų kitimas pagal mẻnesius

Fig. 2.15. Changes in passenger flows by month

Iš 2.15 pav. matyti, kad keleivių srautų pikas yra rugpjūčio mėnuo. Tai greičiausiai lemia atostogų laikotarpio pabaiga ir mokslo metų pradžia.

\subsection{Keleivinių riedmenų parko būklès analizè}

\subsubsection{Keleivinių riedmenų tipai}

$\mathrm{AB}$ „Lietuvos geležinkeliai“ keleivius veža elektriniais ir dyzeliniais traukiniais, automotrisemis ir keleiviniais traukiniais, traukiamais šilumvežių. Šių tipų traukiniai toliau nagrinejjami.

Elektrinis traukinys - tai keleivinių vagonų junginys, sudarytas iš varomųjų, prikabinamujų ir valdymo vagonų. Varomieji vagonai turi kèbula, skirtą keleiviams vežti, elektros traukos variklius, srovès ėmiklius, vežimèlius, automati- 
nes sankabas, suslègtojo oro tiekimo sistema, pagalbinę irangą. Prikabinamieji vagonai iš esmès skiriasi nuo varomujų tuo, kad neturi elektros traukos varikliu, srovès ėmiklių. Valdymo vagonai ypatingi tuo, jog turi traukinio valdymo įrangą ir mašinisto kabiną. Galètų būti formuojami dviejų vagonų traukiniai.

Dyzelinis traukinys - tai keleivinių vagonų junginys, sudarytas iš variklinių ir prikabinamuju vagonų. Kai kurie modernizuoti dyzeliniai traukinai turi valdymo vagonus. Dyzelinio traukinio variklinis vagonas turi kẻbulą keleiviams vežti, dyzelinę jëgainę (dyzelinị varikli ir transmisija), mašinisto kabiną su traukinio valdymo ịranga, vežimèlius, automatines sankabas, suslègtojo oro sistema, pagalbinę ịangą. Valdymo vagonas skiriasi tuo, kad neturi jègainès (jis turi mašinisto kabiną su traukinio valdymo įranga). Prikabinamasis vagonas neturi nei jègainès, nei mašinisto kabinos.

Dažniausiai dyzeliniai traukiniai formuojami iš penkių vagonų: variklinis vagonas, trys prikabinamieji vagonai, variklinis vagonas. Esant mažiems keleivių srautams $A B$ „Lietuvos geležinkeliai“ pradèjo naudoti modernizuotus dyzelinius traukinius iš trijų vagonų: variklinis vagonas, prikabinamasis vagonas, valdymo vagonas.

Automotrisè - tai geležinkelio riedmuo, skirtas keleiviams vežti, turintis kẻbulą keleiviams vežti, jẻgainę (variklį ir transmisija), dvi mašinisto kabinas su valdymo i̇ranga, vežimèlius, automatines sankabas, suslègtojo oro sistema, pagalbinę irrangą. Automotrisès būna elektrinès arba dyzelinès. AB „Lietuvos geležinkeliai“ eksploatuojamos automotrisès yra dyzelinès. Automotrisé gali būti formuojama su papildomu vagonu.

Keleivinis traukinys, traukiamas šilumvežio, sudarytas iš keleivinių vagonų ir šilumvežio. Vagonų skaičius atitinka ruožo keleivių skaičių.

\subsubsection{Keleivinių lokomotyvų skaičiaus pasiskirstymas pagal pagaminimo metus}

Keleivinių lokomotyvų skaičiaus pasiskirstymas pagal pagaminimo metus parodytas 2.16 pav.

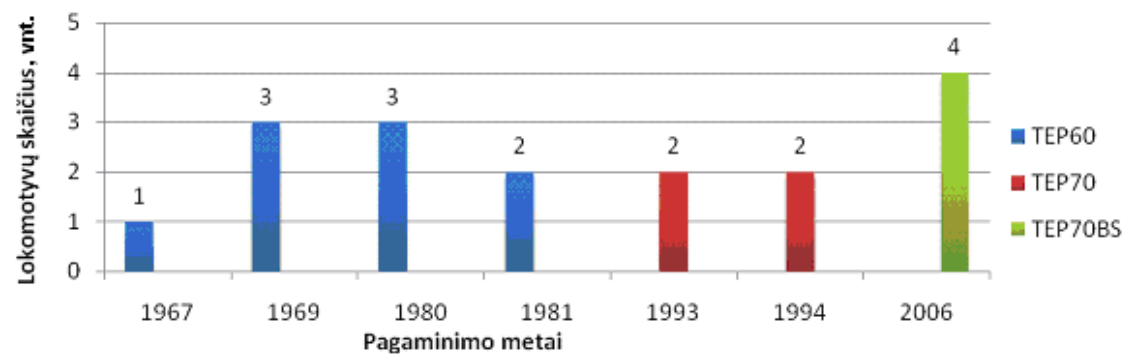

2.16 pav. Keleivinių lokomotyvų skaičiaus pasiskirstymas pagal pagaminimo metus

Fig. 2.16. Passenger locomotives distribution in accordance with years of manfacture 
2.16 pav. matyti, kad didžiausią dali sudaro TEP60 serijos lokomotyvai, pagaminti iki $1981 \mathrm{~m}$. imtinai. Naujausi yra keturi vienetai TEP70BS lokomotyvų, pagamintų $2006 \mathrm{~m}$.

Šiuo metu šilumvežiai kabinami prie vietinių ir tarptautinių maršrutų traukinių. Analizuojant esamą AB „Lietuvos geležinkeliai“ šilumvežių parko būklę, keleivinių traukinių maršrutus, keleivių srautus, elektrifikavimo planus, galima numatyti ši keleivinių šilumvežių parko perspektyvini atnaujinimo planą:

1. Pakeitus vieninteli šalies vidinị keleivinị traukinį su lokomotyvų trauka Vilnius-Klaipéda šiuolaikiniais dyzeliniais moduliniais traukiniais, galima būtų išspręsti senstančių TEP60 šilumvežių problemą, kurių ekonomiškumas, patikimumas ir ekologiškumo lygis jau senai neatitinka šiuolaikinių reikalavimų.

2. Likusi šilumvežio parko dalis - lokomotyvai TEP70, naudojamų tik tarptautiniuose traukinių maršrutuose.

3. Pasibaigus šių lokomotyvų resursui, naujų lokomotyvų pirkimas bus susijęs su Lietuvos ir kaimyninių šalių elektrifikacijos planais, tranzitinių traukinių skaičiumi, naujų maršrutų ivvedimu, keleivių srautų pokyčiais, „Rail Baltica“ projekto igyvendinimu ir kitais veiksniais. Todèl keleivinių šilumvežiu parko atnaujinimo projektai turi būti operatyvūs ir orientuojami i palyginti trumpalaikę perspektyva, naudojant traukinių parinkimo modelius, atsižvelgiant į nuolat kintančius keleivių vežimo aplinkos veiksnius.

\subsubsection{Keleivinių vagonų parko bendroji analizè}

Keleivinių vagonu parko statistikos analizè atlikta remiantis 2009 m. sausio $1 \mathrm{~d}$. duomenimis.

Keleivinių vagonų parką sudaro 138 vagonai, iš jų: 7 minkštieji, 13 miegamųjų atviro tipo, 69 kupinių, 36 sedimieji, 8 restoranai, 3 bagažo ir 2 tarnybiniai. Š parką galima suskirstyti i minkštuosius, kietuosius, vagonus-restorano vagonus ir kt. Vagonų skaičiaus pasiskirstymas pagal tai pateiktas 2.17 pav.

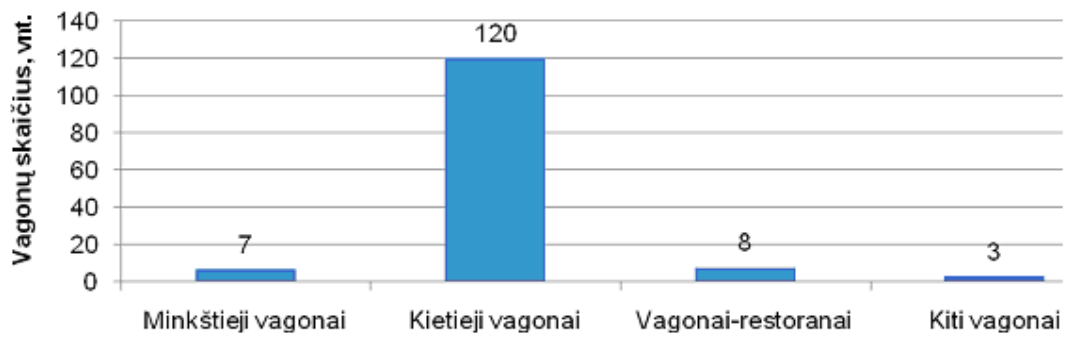

2.17 pav. Vagonų skaičiaus pasiskirstymas

Fig. 2.17. Distribution of the number of passenger carriages 
2.17 pav. matyti, jog absoliučią daugumą (120 iš 138) sudaro kietieji vagonai. Kietieji vagonai būna kupiniai ir nekupiniai, todèl nagrinejjant vagonų skaičių, pastaruosius galima išskirti. Vagonu skaičiaus pasiskirstymas, išskiriant kupinius ir nekupinius vagonus, pateiktas 2.18 pav.

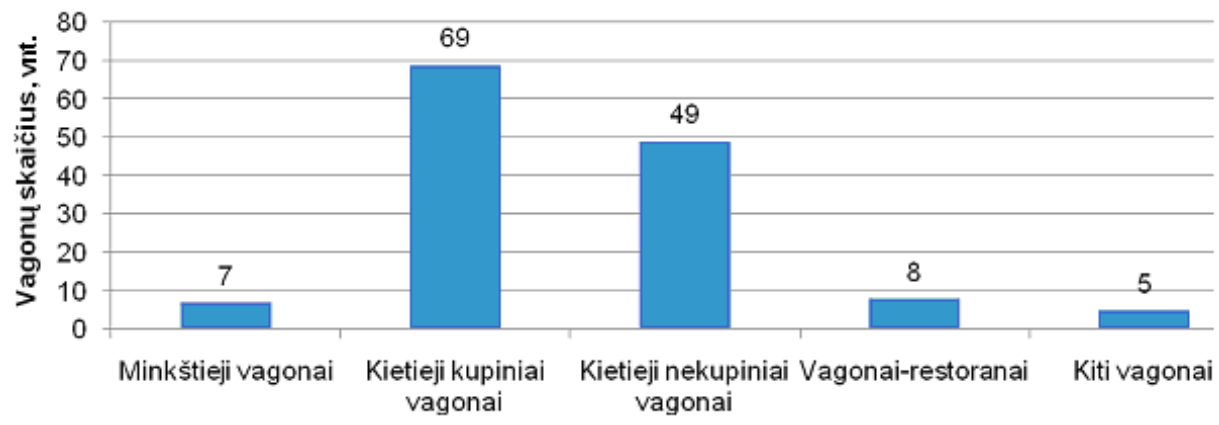

2.18 pav. Vagonų skaičiaus pasiskirstymas, išskiriant kupinius ir nekupinius vagonus Fig. 2.18. Distribution of the number of wagons, excluding coupe and non coupe carriages

Šiuo metu kietujų kupinių ir nekupinių vagonų skaičius skiriasi (atitinkamai 69 ir 49 vagonai). Toks išskyrimas būtinas, nes šių vagonų bilietų kainos skirtingos. Tai svarbu skaičiuojant gautas pajamas.

Kadangi ne visi vagonai naudojami keleiviams vežti (dalis jų remontuojami ar modernizuojami), todèl vagonų parko naudojimo koeficientui nustatyti reikia žinoti vagonų, kurie paprastai remontuojami, skaičių. Dirbančių ir laukiančių remonto vagonų skaičius pateiktas 2.19 pav.

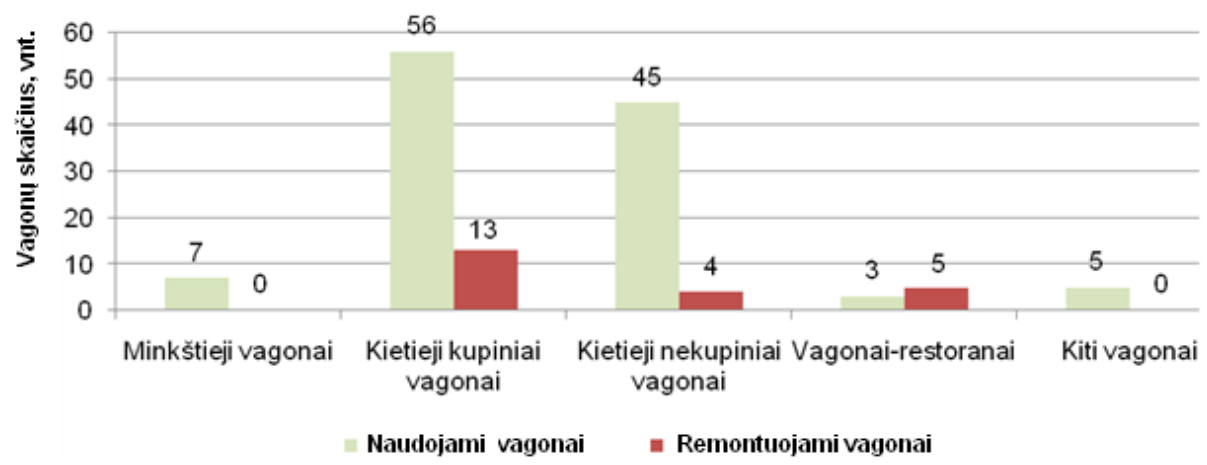

2.19 pav. Vidutinis naudojamų ir remonto laukiančių vagonų skaičius

Fig. 2.19. Average number of operating and repairing passenger carriages 
Kaip matyti iš 2.19 pav., remontuojama apie 19 proc. kietujų kupinių vagonų ir 8 proc. kietujų nekupinių vagonų.

Praktikoje vagonų parko naudojimo koeficientas apskaičiuojamas taip:

$$
K=\frac{N_{d}}{N_{b}}
$$

čia: $N_{d}$ - naudojamų vagonų skaičius; $N_{b}$ - bendras vagonų skaičius parke.

$$
K=\frac{116}{138}=0,84 .
$$

Dabar naudojamo keleivinio parko efektyvumą tikslinga išskirti pagal atskiras rūšis (elektrinis traukinys, dyzelinis traukinys, šilumvežis-vagonas ir automotrisè) vienam vagono našumui $Q_{v}$, ir pagal keleivius $W_{v k}$, ir pagal pajamas $Q_{v p}$ :

$$
\begin{aligned}
& Q_{v k l}=\sum L_{i} / N_{d i} ; \\
& Q_{v k p}=\sum P_{i} / N_{d i} ;
\end{aligned}
$$

čia: $\sum L_{i}-$ kel. km kelio $i$-tosios rūšies vagonui per metus per metus; $\sum P_{i}-$ pajamos, gautos vežant keleivius $i$-tosios rūšies vagone per metus, Lt; $N_{d i}$ - keleivinių vagonų darbo parkas.

Bendras $\mathrm{AB}$ „Lietuvos geležinkeliai“ keleivinių vagonų skaičiaus pasiskirstymas pagal jų pagaminimo metus pateiktas 2.20 pav.

2.20 pav. matyti, kad didžioji dalis vagonų pagaminta nuo 1987 iki 1994 m. imtinai.

Neblogą keleivinių vagonų parko naudojimo koeficientą daugiausia lemia tai, kad parke mažai senos gamybos (1964-1986 m.) vagonų. Tačiau dar yra tam tikras rezervas parko naudojimo koeficientui didinti gerinant vagonų techninės priežiūros ir remonto sąlygas bei kokybę.

Tolesniam keleivinių sąstatų optimizavimui būtina žinoti technines atskirų vagonų charakteristikas, ypač keleivių skaičiaus ir komforto požiūriu. Duomenys apie miegamuosius vagonus pateikti 2.5 lenteleje, o apie sèdimuosius - 2.6 lentelèje.

Siekiant suformuoti racionalius traukinių sąstatus, būtina žinoti jų atskirų rūšių keleivinių riedmenų vagonų jungimo galimybes pagal esamą keleivių skaičiu. Śie duomenys pateikti 2.7 ir 2.9 lentelèse. 


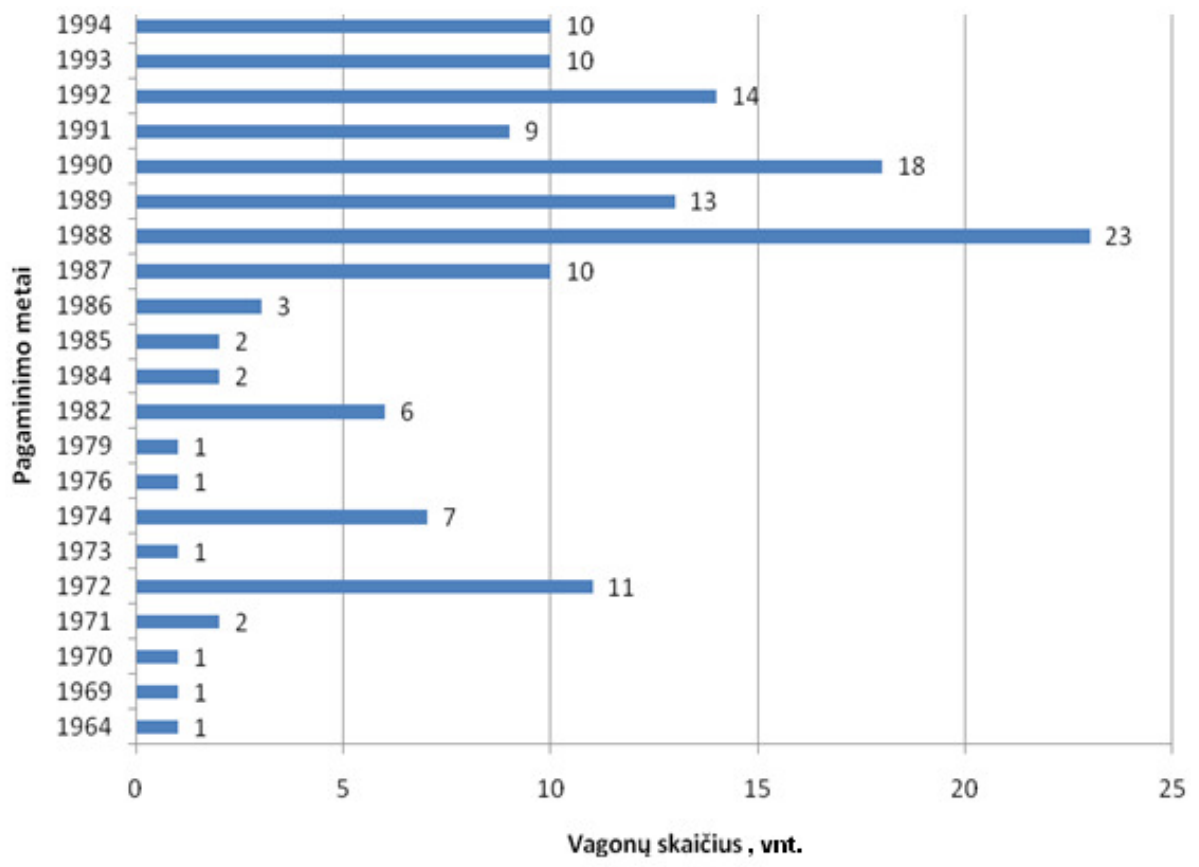

2.20 pav. Bendras keleivinių vagonų skaičiaus pasiskirstymas pagal ju pagaminimo metus

Fig. 2.20. The total number of passenger carriages by their first year

2.5 lentelè. Techniniai miegamujų keleivinių vagonų duomenys

Table 2.5. Sleeping passenger carriages specifications

\begin{tabular}{|l|c|c|c|}
\hline \multirow{2}{*}{ Vagono tipas } & \multicolumn{3}{c|}{ Vietų skaičius vagone } \\
\cline { 2 - 4 } & gulimujų & stovimuju & iš viso \\
\hline Minkštieji & 18 & 0 & 18 \\
\hline Kietieji kupiniai & 36 & 0 & 36 \\
\hline $\begin{array}{l}\text { Kietieji nekupiniai (paprastieji mie- } \\
\text { gamieji) }\end{array}$ & 54 & 0 & 54 \\
\hline
\end{tabular}

2.6 lentelè. Techniniai sėdimujų keleivinių vagonų duomenys

Table 2.6. Seating passenger carriages specifications

\begin{tabular}{|l|c|c|c|}
\hline \multirow{2}{*}{ Vagono tipas } & \multicolumn{3}{c|}{ Vietu skaičius vagone } \\
\cline { 2 - 4 } & sėdimuju & stovimujų & iš viso \\
\hline Sėdimasis aštuonių vietų kupė & 72 & 0 & 72 \\
\hline Sédimasis su dviem kupė & 56 & 0 & 56 \\
\hline Sédimasis & 62 & 0 & 62 \\
\hline
\end{tabular}


2.7 lentelè. $A B$ „Lietuvos geležinkeliai“" galimi elektrinių traukinių sąstatų deriniai

Table 2.7. JSC "Lithuanian Railways" possible combinations of electric train set

\begin{tabular}{|l|c|c|c|c|c|}
\hline $\begin{array}{c}\text { Elektriniai } \\
\text { traukiniai }\end{array}$ & $\begin{array}{c}\text { Sėdimuju } \\
\text { vietu }\end{array}$ & $\begin{array}{c}\text { Masé, } \\
\mathrm{t}\end{array}$ & $\begin{array}{c}\text { Didžiausias } \\
\text { greitis, } \\
\mathrm{km} / \mathrm{val} .\end{array}$ & $\begin{array}{c}\text { Elektros } \\
\text { energijos } \\
\text { sanaudos } \\
100 \mathrm{~km}, \\
\mathrm{kWh}\end{array}$ & $\begin{array}{c}\text { Telemechanine } \\
\text { mašinisto } \\
\text { budrumo sis- } \\
\text { tema }\end{array}$ \\
\hline EJ575 (dviaukštis) & 304 & 210 & 160 & 530 & $\begin{array}{c}\text { Taip } \\
(1 \text { asmuo) }\end{array}$ \\
\hline ER9M (4 vagonu) & 380 & 238 & 120 & 585 & 2 asmenys \\
\hline ER9M (8 vagonu) & 760 & 476 & 120 & 1170 & 2 asmenys \\
\hline ER9M (12 vagonu) & 1140 & 714 & 120 & 1755 & 2 asmenys \\
\hline
\end{tabular}

2.8 lentelè. $A B$ „Lietuvos geležinkeliai“ galimi dyzelinių traukinių sąstatų deriniai

Table 2.8. JSC "Lithuanian Railways" possible combinations of diesel train set

\begin{tabular}{|l|c|c|c|c|c|}
\hline \multicolumn{1}{|c|}{$\begin{array}{l}\text { Dyzeliniai } \\
\text { traukiniai }\end{array}$} & $\begin{array}{c}\text { Sėdimuju } \\
\text { vietu } \\
\text { skaičius }\end{array}$ & Masè, t & $\begin{array}{c}\text { Didžiausias } \\
\text { greitis, } \\
\mathrm{km} / \mathrm{val.}\end{array}$ & $\begin{array}{c}\text { Degalų } \\
\text { sąnaudos } \\
100 \mathrm{~km}, l\end{array}$ & $\begin{array}{c}\text { Telemechanine } \\
\text { mašinisto } \\
\text { budrumo } \\
\text { sistema }\end{array}$ \\
\hline D1 (3 vagonu) & 272 & 178 & 120 & 175 & 2 asmenys \\
\hline D1 (4 vagonu) & 400 & 215 & 120 & 180 & 2 asmenys \\
\hline DR1A (3 vagonu) & 190 & 148 & 120 & 150 & 2 asmenys \\
\hline DR1A (4 vagonu) & 392 & 184 & 120 & 151 & 2 asmenys \\
\hline DR1A (6 vagonu) & 648 & 256 & 120 & 162 & 2 asmenys \\
\hline DR1AM (3 vagonu) & 285 & 135 & 120 & 85 & 2 asmenys \\
\hline $\begin{array}{l}\text { DR1A 300 } \\
\text { (6 vagonu) }\end{array}$ & 520 & 256 & 120 & 162 & 2 asmenys \\
\hline RA2 (2 vagonu) & 124 & 90 & 100 & 75 & Taip (1 asmuo) \\
\hline RA2 (3 vagonu) & 210 & 126 & 100 & 80 & Taip (1 asmuo) \\
\hline Motrisés 620M & 92 & 58 & 120 & 55 & Taip (1 asmuo) \\
\hline Motrisė AR2 & 75 & 50 & 120 & 75 & 2 asmenys \\
\hline
\end{tabular}


2.9 lentelè. $A B$ „Lietuvos geležinkeliai“ galimi atskiru lokomotyvu traukiamų sąstatų deriniai

Table 2.9. JSC "Lithuanian Railways" possible train combinations with a separate locomotive

\begin{tabular}{|c|c|c|c|c|c|}
\hline $\begin{array}{l}\text { Keleiviniai } \\
\text { vagonai }\end{array}$ & $\begin{array}{l}\text { Sėdimuju } \\
\text { vietu } \\
\text { skaičius }\end{array}$ & $\begin{array}{c}\text { Masè (be } \\
\text { šilumvežio), } \mathrm{t}\end{array}$ & $\begin{array}{c}\text { Didžiausias } \\
\text { greitis, } \\
\text { km/val. }\end{array}$ & $\begin{array}{l}\text { Degalų sanau- } \\
\text { dos } 100 \mathrm{~km}, l\end{array}$ & $\begin{array}{c}\text { Mašinisto } \\
\text { budrumo } \\
\text { sistema }\end{array}$ \\
\hline 3 vagonai & 186 & 180 & 120 & \multirow{4}{*}{$\begin{array}{c}\text { Vidutiniškai } \\
400 \\
\text { (TEP70BS) }\end{array}$} & \multirow{4}{*}{2 asmenys } \\
\hline 4 vagonai & 248 & 240 & 120 & & \\
\hline 10 vagonu & 620 & 600 & 120 & & \\
\hline 20 vagonu & 1240 & 1200 & 120 & & \\
\hline
\end{tabular}

Didžiausias sąstato ilgis Lietuvoje imtas pagal Vilniaus stoties galimybes. Realus ribinis ilgis - 10 vagonų, jis priklauso nuo mažesnių stočių kelyje Vilnius-Klaipèda peronų ilgio.

Esama komforto iranga šiuo metu eksploatuojamuose keleiviniuose traukiniuose parodyta 2.10 lentelëje.

2.10 lentelè. $A B$ „Lietuvos geležinkeliai“ komforto įranga šiuo metu eksploatuojamuose keleiviniuose traukiniuose

Table 2.10. Comfort facilities in operation of JSC "Lithuanian Railways" passenger trains

\begin{tabular}{|c|c|c|c|c|c|}
\hline $\begin{array}{l}\text { Keleiviniai } \\
\text { traukiniai }\end{array}$ & Žemagrindis & $\begin{array}{c}\text { Oro } \\
\text { kondicionavimas }\end{array}$ & $\begin{array}{c}\text { Vakuuminiai } \\
\text { tualetai }\end{array}$ & $\begin{array}{c}\text { Salono } \\
\text { vaizdo } \\
\text { stebèjimo } \\
\text { sistema }\end{array}$ & $\begin{array}{c}\text { Pritaikyta } \\
\text { neigaliesiems }\end{array}$ \\
\hline \multicolumn{6}{|l|}{$\begin{array}{l}\text { Elektriniai } \\
\text { traukiniai: }\end{array}$} \\
\hline ER9M & $\mathrm{Ne}$ & $\mathrm{Ne}$ & Dalyje & $\mathrm{Ne}$ & $\mathrm{Ne}$ \\
\hline $\begin{array}{l}\text { EJ575 } \\
\text { (dviaukštis) }\end{array}$ & Taip & Taip & Taip & Taip & Taip \\
\hline \multicolumn{6}{|l|}{$\begin{array}{l}\text { Dyzeliniai } \\
\text { traukiniai: }\end{array}$} \\
\hline D1 (3 vagonu) & $\mathrm{Ne}$ & $\mathrm{Ne}$ & $\mathrm{Ne}$ & $\mathrm{Ne}$ & $\mathrm{Ne}$ \\
\hline $\begin{array}{l}\text { DR1 serija } \\
\text { (3 vagonų) }\end{array}$ & $\mathrm{Ne}$ & $\mathrm{Ne}$ & Dalyje & $\mathrm{Ne}$ & $\mathrm{Ne}$ \\
\hline RA2 (2 vagonu) & $\mathrm{Ne}$ & $\begin{array}{l}\text { Priverstinè } \\
\text { ventiliacija }\end{array}$ & Taip & $\mathrm{Ne}$ & Taip \\
\hline Motrisès 620M & $\begin{array}{c}\text { Papildomas } \\
\text { laiptelis }\end{array}$ & Taip & Taip & Taip & Taip \\
\hline
\end{tabular}


2.10 lentelejje nepateiktos mechaninių virpesių ir triukšmų charakteristikos vagonų salonuose. Vibracijos itin pavojingos žmogaus sveikatai ir labai blogina komforto sąlygas. Todèl šiame darbe jų nagrinejjimui bus atkreiptas ypatingas dèmesys (4 skyrius).

\subsection{Antrojo skyriaus išvados}

1. Per pastaruosius ketverius metus vežtų keleivių skaičius Lietuvoje stabilizavosi ir vidutiniškai sudaro 4,2 mln. per metus, tačiau už parduotus bilietus gautos pajamos sudare vidutiniškai tik $13,7 \%$ patiriamų išlaidų.

2. Pagrindinès priežastys, lemiančios nuostolius vežant keleivius geležinkeliais - mažas keleivių skaičius, šiuolaikiškų riedmenų trūkumas, prasta geležinkelių infrastruktūra, neracionalus riedmenų naudojimas atskiruose vietinio susisiekimo ruožuose.

3. Prognozuojama, kad $2030 \mathrm{~m}$. keleivių skaičius gali išaugti iki 3,5 karto per metus (apie $14 \mathrm{mln}$.). Pastaraisiais metais geležinkeliais vežama tik apie $1,1 \%$ visų keleivių. Tikimasi, kad minètas keleivių prieaugis turètų atsirasti perimant dali keleivių iš automobilių transporto.

4. Keleivinių riedmenų parkas šiuo metu nèra optimaliai pritaikytas keleiviams vežti vietiniais ruožais su smarkiai kintamu keleiviu skaičiumi ir atstumais. Parkas nėra pritaikytas ỉvairių vežimo priemonių lanksčiai transformacijai pagal kintamą keleivių skaičių. Todèl kita darbo dalis yra skirta optimalios traukos parinkimui ir sąstatų ilgio formavimui pagal kiekvienu momentu susidarančią situaciją. 



\section{Matematinio modelio sudarymas ir taikymas priemonèms parinkti}

Skyriuje nagrinejjamas racionalių sąstatų keleiviams vežti parinkimas, atsižvelgiant $i$ jų srautus maršrutuose, priemonių tipą ir galimą traukos rūši siekiant maksimaliai sumažinti patiriamas išlaidas. Skyriaus tematika paskelbtas autoriaus straipsnis (Dailydka 2010).

\subsection{Racionalių keleivinių sąstatų parinkimo privalumai}

Bet kuri naudojama technika tiek geležinkelyje, tiek visame ūkyje bus efektyviausiai naudojama tik tada, kai bus maksimaliai apkrauta. Kalbant apie keleivių vežimą geležinkeliu, tai atitinka kuo didesni vagonų pripildymą keleiviais. Pastaruoju metu yra ruožų (Šiauliai-Mažeikiai, Klaipèda-Šilutė, KaunasKaišiadorys), kuriuose vietų užimtumas traukiniuose sudaro vos $10 \%$ ar mažiau.

Skirtingomis kryptimis ir atskiruose ruožuose keleivių skaičius yra labai ivairus: jis priklauso ne tik nuo keleivių traukos centrų išsidèstymo, bet ir nuo paros ar metų laiko. Šiuo metu taikoma sąstatų ilgio ir traukos priemonių parin- 
kimo praktika ne visada racionali. Šie parametrai paprastai keičiami tik vasaros ar žiemos periodams. Tai puikiai iliustruoja pateiktas pavyzdys 3.1 pav.

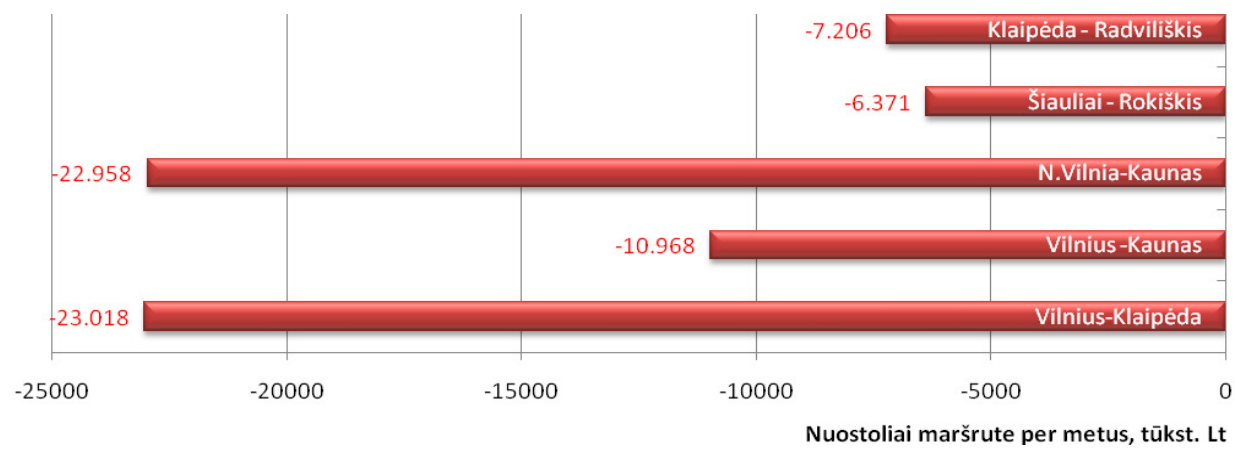

3.1 pav. Pagrindiniuose maršrutuose per metus vidutiniškai patiriami nuostoliai

Fig. 3.1. Average annual losses on the main routes

Kaip buvo minèta 2 skyriuje, pastaruoju metu Lietuvos geležinkelių tinkle naudojama elektrinè ir šiluminè trauka: dyzeliniai traukiniai, šilumvežiai ir automotrisès. Tiek ekologiniu, tiek ekonominiu požiūriu geriausia būtų naudoti elektrinę trauką. Nors $\mathrm{AB}$ „Lietuvos geležinkeliai“ planuose numatoma visų ruožų elektrifikacija, tačiau igyvendinti tai nèra paprasta. Visu pirma reikalingos didžiulès investicijos, o aptarnaujant tranzitinius traukinius būtina, kad ir mūsų kaimynai elektrifikuotu savas linijas. Tačiau artimiausiu metu Lietuvos geležinkeliams būtina pasirinkti ne tik racionaliausius traukinių sąstatus, bet ir kuo pigesnę trauką. Išanalizavus pastarujų šešerių metų ivairiais maršrutais eksploatuotų riedmenų duomenis, apskaičiuotos vidutinès sąnaudos, tenkančios vieno vagono vienam kilometrui, esant skirtingoms traukoms. Lyginamosios sąnaudos pagal traukas pateiktos 3.1 lentelèje.

Lentelès duomenys rodo, kad pigiausia vieno vagono trauka yra elektrinè. Toliau šiame skyriuje pabandysime nustatyti 1 traukinio km sąnaudas optimizavus sąstatų ilgius priklausomai nuo keleivių skaičiaus ir parinkus pačią palankiausią trauka.

Ištyrus vietiniais maršrutais važiuojančių keleivių dinamiką nustatyta, kad daugiausia atvejų jų skaičius neviršija 80 žmonių, t. y. ne daugiau nei telpa i vieną vagoną. Śiuo aspektu automotrisè yra patraukliausia priemonè.

Remiantis elektros ir šiluminių variklių teorija, galima konstatuoti, kad $1 \mathrm{kWh}$ atlieka apie 1,6 karto daugiau naudingojo darbo esant elektrinei traukai, lyginant su šilumine. Taigi elektrinè trauka visuomet yra pranašesnè už šiluminę, ne tik ekonominiu, bet ir ekologiniu požiūriu. 
3.1 lentelė. Vieno vagono kilometro išlaidų, esant skirtingoms traukoms, palyginimas Table 3.1. Comparison between different traction of one carriage per kilometre cost

\begin{tabular}{|c|l|c|}
\hline $\begin{array}{c}\text { Eil. } \\
\text { Nr. }\end{array}$ & \multicolumn{1}{|c|}{ Traukos rūšis } & Sąnaudos, Lt \\
\hline 1 & Elektrinè trauka & 5,58 \\
\hline 2 & Automotrisė & 5,93 \\
\hline 3 & Dyzelinè trauka & 6,02 \\
\hline 4 & Šilumvežis & 8,03 \\
\hline
\end{tabular}

Dèl ịvairių priežasčių parinkti mažiausiai nuostolingą (elektrinę) trauką visiems maršrutams šiuo metu nèra galimybių, todèl, siekiant mažinti patiriamus keleivių vežimo nuostolius, tikslinga, atsižvelgiant ị technologines galimybes ir keleivių srautus, išanalizuoti traukos priemonių ir vagonų skaičiaus atskiruose maršrutuose galimus derinius. Tam tikslui reikia sudaryti matematini modeli, kuriam taikant netiesinių lygčių su daugeliu kintamųjų ir apribojimais ekstremumo paieškos metodą, būtų galima optimizuoti išlaidų komponenčių visumą ir taip konkrečiam maršrutui (atsižvelgiant i metų, paros laika) parinkti racionaliausią traukos priemonių ir vagonų skaičiaus derini.

\subsection{Keleivių srautai pagal ruožus ir vežimo priemonių parinkimo modelis}

Kadangi pajamos vežant keleivius surenkamos už parduotus bilietus, todèl jas lemia bendras geležinkelių transporto keleivių skaičius. Nuostolius iš šios veiklos daugiausia lemia mažas keleivių skaičius. Be to, atskiri ruožai apkrauti labai nevienodai ir netolygiai. Todèl akivaizdžiai atsiranda poreikis keisti vagonų skaičiu pačiame maršrute. Norint sužinoti šiuo metu esamą padèti ruožuose, buvo ištirta keleiviu skaičiaus kitimo dinamika maršrutuose.

Iš kelių galimų regresijos lygčių buvo pasirinkta ta kreivè, kurios koreliacijos koeficientas buvo didžiausias ir atitinkamai kvadratinė paklaida mažiausia. Apdoroti statistiniai duomenys pateikti 3.2 lenteleje. 
3.2 lentelè. Keleivių skaičiaus dinamika pagal maršrutus

Table 3.2. Dynamics of the number of passengers in terms of routes

\begin{tabular}{|c|c|c|}
\hline Maršrutas & Regresijos lygtis & $\begin{array}{c}\text { Determinacijos } \\
\text { koeficientas }\end{array}$ \\
\hline 1 & 2 & 3 \\
\hline Rokiškis-Šiauliai & $K(x)=0,0217 x^{3}-0,7030 x^{2}+7,4925 x-7,3577$ & $R^{2}=0,9462$ \\
\hline Šiauliai-Rokiškis & $\begin{array}{l}K(x)=0,0003 x^{5}-0,0198 x^{4}+0,4163 x^{3}-3,4857 x^{2} \\
+8,718 x+22,8790\end{array}$ & $R^{2}=0,6258$ \\
\hline Vilnius-Šiauliai & $K(x)=0,0030 x^{3}-0,01930 x^{2}+0,1267 x+8,3938$ & $R^{2}=0,8088$ \\
\hline Šiauliai-Vilnius & $K(x)=3,3364 x+34,4440$ & $R^{2}=0,8335$ \\
\hline Šiauliai-Kaunas & $K(x)=0,0161 x^{3}-0,4527 x^{2}+2,3664 x+25,856$ & $R^{2}=0,8357$ \\
\hline Kaunas-Šiauliai & $K(x)=-0,2934 x^{2}+3,5786 x+24,777$ & $R^{2}=0,8688$ \\
\hline $\begin{array}{l}\text { Klaipèda- } \\
\text { Radviliškis }\end{array}$ & $K(x)=-0,0018 x^{3}+0,0263 x^{2}+0,0594 x+22,276$ & $R^{2}=0,5330$ \\
\hline $\begin{array}{l}\text { Radviliškis- } \\
\text { Klaipeda }\end{array}$ & $K(x)=-0,012 x^{3}$ & 9770 \\
\hline $\begin{array}{l}\text { Vilnius- } \\
\text { Marcinkonys }\end{array}$ & $K(x)=-0$ & $R^{2}=$ \\
\hline $\begin{array}{l}\text { Marcinkonys- } \\
\text { Vilnius }\end{array}$ & $K(x)=1,2237 x^{2}-9,3085 x+51,435$ & $R^{2}=0,9154$ \\
\hline Vilnius-Varèna & $K(x)=0,0809 x^{3}-0,6358 x^{2}-15,408 x+165,77$ & $R^{2}=0,9507$ \\
\hline Varėna-Vilnius & $K(x)=-0,1929 x^{3}+5,0374 x^{2}-25,36 x+58,625$ & $R^{2}=0,9456$ \\
\hline Vilnius-Ignalina & $K(x)=0,0075 x^{3}-0,5798 x^{2}+1,5123 x+88,004$ & $R^{2}=0,9491$ \\
\hline Ignalina-Vilnius & $K(x)=-5,7084 x+106$ & $R^{2}=0,8896$ \\
\hline Vilnius-Turmantas & $K(x)=-0,1654 x^{2}-1,6307 x+101,08$ & $R^{2}=0,9509$ \\
\hline Turmantas-Vilnius & $K(x)=4,8757 x+23,352$ & $R^{2}=0,9441$ \\
\hline Vilnius-Kena & $K(x)=-0,216 x^{3}+1,8422 x^{2}-4,0205 x+17,484$ & $R^{2}=0,8347$ \\
\hline Kena-Vilnius & $K(x)=-0,216 x^{3}+1,8422 x^{2}-4,0205 x+17,484$ & $R^{2}=0,8347$ \\
\hline Kaunas-Šeštokai & $K(x)=-4,2146 x+66,434$ & $R^{2}=0,8767$ \\
\hline Šeštokai-Kaunas & $K(\mathrm{x})=-0,0411 x^{3}+1,3483 x^{2}-8,4348 x+13,545$ & $R^{2}=0,9355$ \\
\hline Kaunas-Kybartai & $K(x)=-6,9525 x+95,152$ & $R^{2}=0,9314$ \\
\hline Kybartai-Kaunas & $K(x)=-0,2051 \mathrm{x}^{3}+3,7733 x^{2}-12,143 x+17,253$ & $R^{2}=0,9640$ \\
\hline Vilnius-Trakai & $K(x)=-0,8882 x^{2}+1,8878 x+9,2477$ & $R^{2}=0,8256$ \\
\hline Trakai-Vilnius & $K(x)=-2,5534 x+13,689$ & $R^{2}=0,7528$ \\
\hline Vilnius-Kaunas & $K(x)=2,2145 x+0,4758$ & $R^{2}=0,8395$ \\
\hline Kaunas-Vilnius & $K(x)=-0,1092 x^{3}+2,2145 x^{2}-9,0851 x+17,266$ & $R^{2}=0,9359$ \\
\hline $\begin{array}{l}\text { Radviliškis- } \\
\text { Šiauliai }\end{array}$ & $K(x)=2,5089 x+2,8371$ & $R^{2}=0,9327$ \\
\hline $\begin{array}{l}\text { Šriauliai- } \\
\text { Radviliškis }\end{array}$ & $\begin{array}{l}K(x)=-0,1888 x^{4}+3,1907 x^{3}-17,597 x^{2}+34,816 x \\
-1,6772\end{array}$ & $R^{2}=0,9479$ \\
\hline Vilnius-Stasylos & $K(x)=-6,6047 x+106,92$ & $R^{2}=0,8306$ \\
\hline
\end{tabular}


3.2 lentelès pabaiga

\begin{tabular}{|l|l|l|}
\hline \multicolumn{1}{|c|}{1} & \multicolumn{1}{|c|}{2} & \multicolumn{1}{|c|}{3} \\
\hline Stasylos-Vilnius & $K(x)=0,0469 x^{3}-1,0855 x^{2}+8,489 x-4,5163$ & $R^{2}=0,9531$ \\
\hline Rokiškis-Šiauliai & $K(x)=0,0217 x^{3}-0,703 x^{2}+7,4925 x-7,3577$ & $R^{2}=0,9462$ \\
\hline Šiauliai-Rokiškis & $\begin{array}{l}K(x)=0,0003 x^{5}-0,0198 x^{4}+0,4163 x^{3}-3,4857 x^{2} \\
+8,718 x+22,879\end{array}$ & $R^{2}=0,6258$ \\
\hline Vilnius-Klaipėda & $K(x)=-0,2789 \mathrm{x}^{2}+11,682 \mathrm{x}+4,6654$ & $R^{2}=0,9597$ \\
\hline Klaipėda-Vilnius & $K(x)=1,4374 x^{2}-24,307 x+134,48$ & $R^{2}=0,9165$ \\
\hline Vilnius-Šeštokai & $K(x)=1,9825 x^{2}-34,996 x+164,04$ & $R^{2}=0,8984$ \\
\hline Šeštokai-Vilnius & $K(x)=-1,7647 \mathrm{x}^{2}+25,371 \mathrm{x}-22,646$ & $R^{2}=0,9310$ \\
\hline
\end{tabular}

$K(x)-$ keleivių skaičius; $x-k$-tojo maršruto stotelès numeris; $x=1,2, \ldots n_{k} ; k$-tojo maršruto stotelių skaičius.

Iš 3.2 lentelès matyti, kad reiso keleivių skaičiaus kitimas paklūsta labai įvairioms funkcinėms priklausomybėms. Keliaujančiujų Lietuvos geležinkeliais kaita ruožuose dažniausiai atitinka 1, 2 ir 3-iojo laipsnio regresiniam pasiskirstymui. Taigi parenkant vagonų skaičių i tai būtina atsižvelgti. Tai sudaro šiek tiek keblumų, nes nors kiek viršijus keleivių skaičiu pasirinktuose vagonuose, reikètų skirti papildomą vagona, kuris važiuotų pustuštis. Todèl trumpiausiuose maršrutuose tikslinga išnaudoti stovimas vietas, o likusius kelis keleivius persodinti i autobusą, o kelionę geležinkeliu baigti nustatytame punkte.

\subsection{Matematinio modelio sudarymas}

Modeliu bus apskaičiuojamas pelnas (nuostoliai) $\Delta$ vienam traukinio kilometrui. Supaprastinta modelio forma atrodytų taip:

$$
\Delta=P-I=\sum_{i=1}^{m} P_{i}-\sum_{j=1}^{n} I_{j},
$$

čia: $\Delta$ - pajamų ir išlaidų skirtumas, Lt/trauk. km; $P$ - bendrosios pajamos, Lt/trauk. km; $I-$ bendrosios išlaidos, Lt/trauk. km; $P_{i}-i$-tosios pajamos, gautos už keleivių bilietus, kompensacijos už suteiktas nuolaidas bei dotacijos už negautas pajamas; $I_{j}-j$-osios keleivių vežimo sąnaudos, kuriose ịvertintas mokestis už naudojimąsi viešaja geležinkelių infrastruktūra, riedmenų nusidèvejjimas, išlaidos darbo užmokesčiui, medžiagoms, degalams, remontui ir kitos išlaidos; $m$ - pajamų skaičius (mūsų atveju $m=3$ ); $n$ - išlaidų skaičius (mūsų atveju $n=7)$. 
Ivertinus keleivių vežimo ịkainius, keleivių skaičių bei remiantis norminiais dokumentais, kuriais remiantis apskaičiuojamas dotacijų ir kompensacijų dydis, modelio pajamų sudedamoji dalis atrodytų taip:

$$
\begin{aligned}
& P=\left\{k_{k p} \times P_{1} \times K(x)+k_{d o t}\left(V \times L_{\text {reis }} \times I_{m} \times\right.\right. \\
& \left.\left(1+\frac{r}{100}\right)-k_{k p} \times P_{1} \times K(x)-I_{k}\right)+ \\
& \left.k_{\text {komp }} \times I_{k}\right\} \times \frac{1}{L_{\text {reis }}}
\end{aligned}
$$

čia: $k_{k p}$ - keleivių skaičiaus proporcingumo koeficientas $(1 ; 1,05 ; 1,1 ; 1,15 ; \ldots)$; $P_{1}-$ vidutinis bilietu ikainis Lt, kur $P_{1}=\sum_{k=1}^{n_{k}} l_{k} b_{k m}$ (čia $l_{k}-k$-tojo tarpstočio ilgis, $\mathrm{km} ; b_{k m}-1$ kel. km įkainis, Lt); $K(x)$ - keleivių skaičiaus kitimas ruože pagal tarptstočius, vnt.; $k_{\text {komp }}$ - kompensacijos koeficientas; $V$ - traukinio vagonu skaičius, vnt.; $L_{\text {reis }}-$ atstumas, $\mathrm{km} ; I_{m}$ - maršruto vieno vagono kilometro faktinès sąnaudos, patirtos vykdant viešujų paslaugu isipareigojimą, Lt; $r$ - rentabilumas, $\% ; I_{k}-$ traukinio išlaidų kompensacija dèl keleiviams teikiamų lengvatų, Lt; $k_{d o t}$ - dotacijos koeficientas.

Didžiausią išlaidų dalị (30-40 proc.) sudaro mokestis už naudojimąsi geležinkelio infrastruktūra. Jị sudaro pradinè bei galinè įmokos ir mokestis už kontaktinio tinklo naudojimą. Likusias sudaro darbo užmokesčio, degalu̧, tepalų, remonto bei kitos išlaidos. Jei vagonų daugiau nei vienas, šių komponentų suma dauginama iš funkcijos, nusakančios išlaidų padidejimą priklausomai nuo vagonų skaičiaus. Kad nereikètu skaičiuoti išlaidų kiekvienai traukai atskirai, modelyje viskas apskaičiuota elektrinei traukai, o kitoms apskaičiuojama pritaikius traukos koeficienta, kuris yra elektrinès ir kitos pasirinktos traukos santykis. Taigi, ivertinus visas išvardytas komponentes, modelio išlaidų sudedamoji dalis atrodytų taip:

$$
\begin{aligned}
& I=\left[\left(\left(\frac{E_{k e l}}{R_{k e l}}+\frac{E_{k t}}{R}\right) \times \frac{R_{1}}{R_{k e l}}+\left(\frac{I_{k e l}}{A_{k e l}}+\frac{I_{k t}}{A}\right) \times \frac{A_{k e l}}{R_{k e l}}+\frac{I_{k o n t}}{R_{k e l}}\right)+\right. \\
& \left.\left(D_{u \check{z}}+M+D_{t}+N+R_{k}+K_{i \check{s}}\right) \times f\left(Z_{v a g}\right)\right] \times a
\end{aligned}
$$

čia: $E_{k e l}$ - traukinių eismo organizavimo ir valdymo išlaidos, patiriamos tik dèl geležinkelio i̇monių, vežančių keleivius ir bagaža, aptarnavimo, Lt; $E_{k t}-$ traukinių eismo organizavimo ir valdymo išlaidos, patiriamos tiek dèl geležinkelio imonių, vežančių keleivius ir bagaža, tiek dèl geležinkelio įmonių, vežančių kro- 
vinius, priežiūros; $R_{k e l}$ - keleivinių traukinių rida (trauk. $\mathrm{km}$ ); $R$ - visų traukinių rida (trauk. km); $R_{1}$ - rezervuota traukinių rida (trauk. $\mathrm{km}$ ) $I_{k e l}$ - viešosios geležinkelių infrastruktūros išlaidos, patirtos tik dèl geležinkelio imonių, vežančių keleivius ir bagažą, priežiūros, Lt; $I_{k t}$ - viešosios geležinkelių infrastruktūros išlaidos, patirtos tiek dèl geležinkelio įmonių, vežančių keleivius ir bagaža, tiek dèl geležinkelio i̇monių, vežančių krovinius, priežiūros, Lt; $A_{k e l}-$ keleivinių traukinių darbo apimtis, tkm bruto; $A$ - visų traukinių darbo apimtis (tkm bruto); $I_{\text {kont }}$ - išlaidos kontaktiniam tinklui, Lt; $D_{u \check{z}}-$ darbo užmokestis, Lt/vag. km; $M-$ išlaidos medžiagoms, Lt/vag. km; $D_{t}$ - išlaidos degalams, tepalams, Lt/vag. km; $N$ - riedmenų nusidèvejjimas, Lt/vag. $\mathrm{km} ; R_{k}-$ remonto išlaidos, Lt/vag. $\mathrm{km}$; $K_{i \check{s}}$ - kitos išlaidos, Lt/vag. km; $a$ - traukos koeficientas, čia $a=\sqrt[T]{\prod_{t=1}^{T} \frac{a_{d t}}{a_{e t}}}\left(a_{d t}-\right.$ dyzelinès/šiluminès traukos sąnaudos $t$-aisiais metais, Lt/trauk. km; $a_{e t}$ - elektrinès traukos sąnaudos $t$-aisiais metais, Lt/trauk. $\mathrm{km}$; $T$ - metų skaičius); $f\left(Z_{\text {vag }}\right)$ - sąlyginis vagonų skaičius.

Kadangi buvo disponuojama pastarųų šešerių metų statistiniais duomenimis, tikslinga išlaidų komponentems sudaryti regresijos lygtis, nusakančias išlaidų kitimą laiko atžvilgiu ir tokiu būdu modelio galimybes praplèsti nuo esamos situacijos analizès iki prognozių ateityje.

Dotacijų ir kompensacijų už keleivių vežimą dydis tiesiogiai priklauso nuo šalies ekonominès padèties, todèl jų pokyčio laiko atžvilgiu nagrinèti netikslinga, modelyje bus naudojami minèto analizuojamojo periodo šių reikšmių vidurkiai. Infrastruktūros mokestis tiesiogiai priklauso nuo jos išlaikymo ir pletros poreikio, todèl jo sumažinimo ar padidinimo tikslingumas nustatomas atsižvelgiant $\mathfrak{i}$ kitus parametrus. Mūsų atveju jis bus naudojamas kaip sveikasis skaičius, kuris gali būti keičiamas siekiant îvertinti teorines galimybes. Likusių komponenčių pokytis laikui bėgant pavaizduotas 3.2-3.5 pav., kuriuose kintamieji pažymèti skirtingai, nes optimizacija vyks šių skirtingų kintamujų atžvilgiu, t. y. bus ieškoma minimali jų reikšmè. Čia išlaidų kitimo dinamika parodyta per pastaruosius šešerius metus. Grafikuose jie atitinkamai pažymèti skaičiais $x_{i}=1-6$ (2004-2009 m.). Šių išlaidų vidutinès metinès reikšmès apskaičiuotos iš bendrų metinių išlaidų, kurios nurodomos metinèse $\mathrm{AB}$,Lietuvos geležinkeliai“ suvestinèse. 


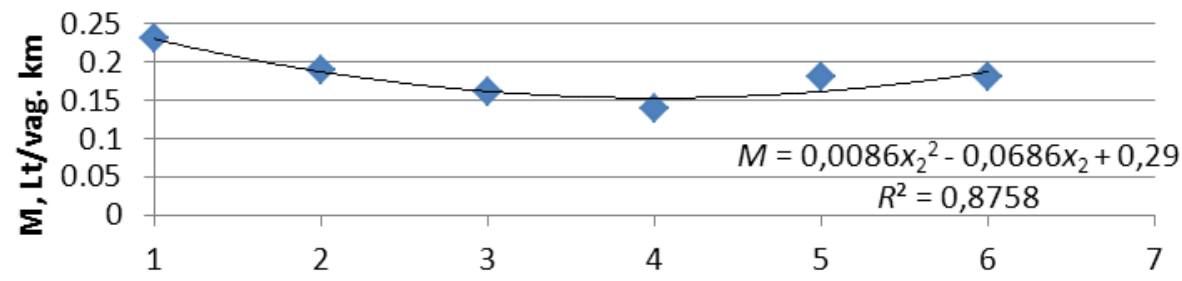

Metai (2004 - 2009)

3.2 pav. Išlaidų medžiagoms kitimo dinamika laiko atžvilgiu

Fig. 3.2. Change of materials costs over time

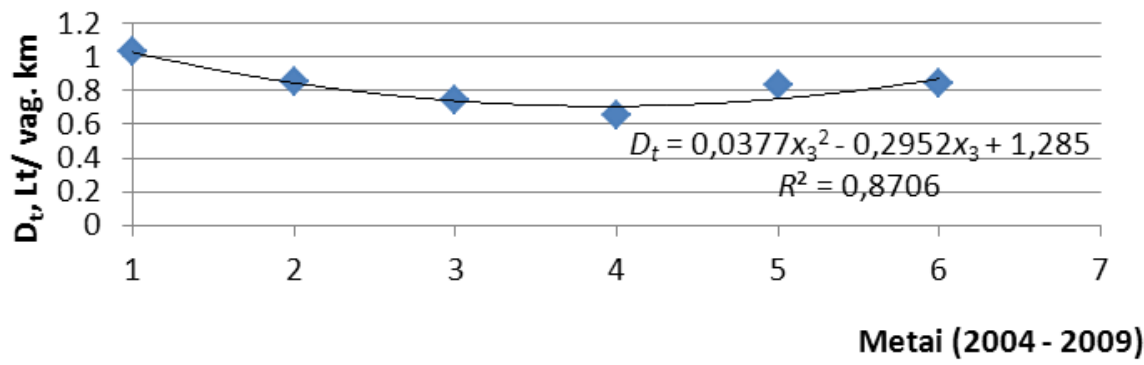

3.3 pav. Išlaidų degalams, tepalams kitimo dinamika laiko atžvilgiu

Fig. 3.3. Change of fuel and oil costs over time

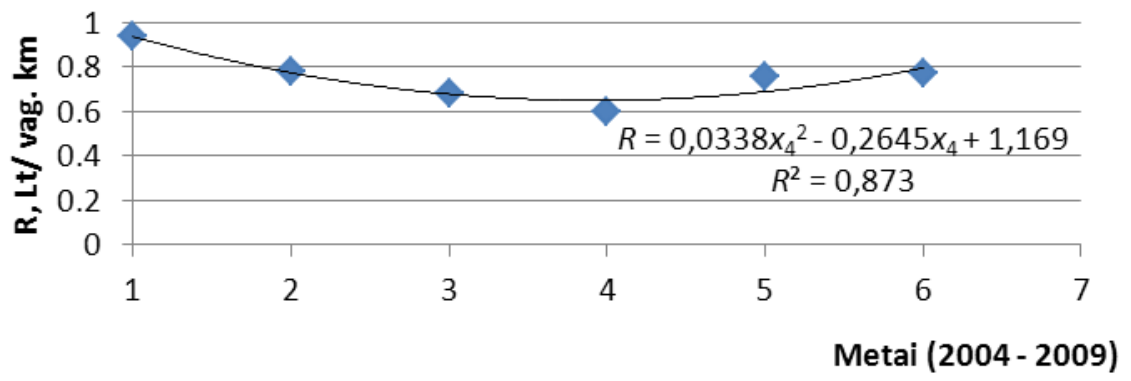

3.4 pav. Išlaidų remontui kitimo dinamika laiko atžvilgiu

Fig. 3.4. Change of repair costs over time 


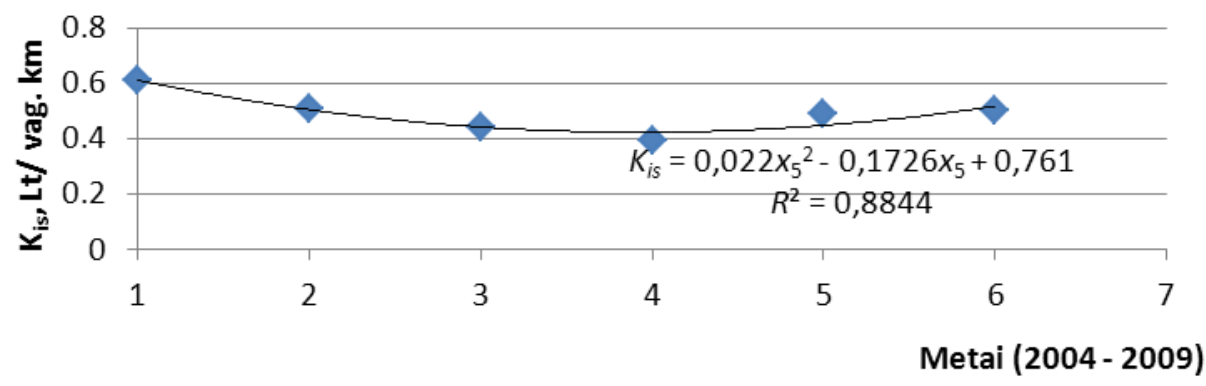

3.5 pav. Kitų išlaidų kitimo dinamika laiko atžvilgiu

Fig. 3.5. Change of other costs over time

Iš 3.2-3.5 pav. pateiktų grafikų matyti, kad per pastaruosius šešerius metus kokybinis šių išlaidų kitimas atitinka to meto kintamas rinkos sąlygas ir degalų, tepalų, atsarginių dalių isigijimo kainas, taip pat ir remontų atlikimo išlaidas. 2004-2007 m. matomas nedidelis šių išlaidų sumažèjimas, o vėliau nežymus didejjimas. Tam ịtakos turejjo ne tik medžiagų kainų kitimas, bet ir kintama atskirų dedamųjų dalis, pvz., riedmenų nusidèvejjimas, naujų keleivių vežimo priemonių issigijimas ir pan. Per nagrinejjamą laikotarpi atskirų išlaidų sudedamujų dalių pokytis nuo maksimalių iki minimalių svyruoja apie 30 proc. Žinia, kad prognozuoti šių išlaidų pokyti ateityje sudètinga, nes jos priklauso ne tik nuo riedmenų eksploatacinių charakteristikų pokyčio, bet ir nuo rinkos sąlygų. Tačiau minètas funkcijas, kaip kokybinių rodiklių kitimą su pakankamu patikimumu, galima naudoti sudarytame modelyje išlaidoms prognozuoti perspektyvoje parenkant racionaliausią trauką ir sąstatus atskiruose ruožuose, nes visais atvejais nors ir kokios būtų ekonominès sąlygos, keleivinių riedmenų parkas bus naujinamas palaipsniui pagal sudarytą ir nuolat atnaujinamą planą.

Suprantama, kad formuojant sąstatus sąnaudos priklausys ir nuo vagonų skaičiaus. Mūsų atveju tai labai svarbu, nes modelis parinks minimalų vagonų skaičiu, skirtą konkretaus ruožo keleiviams aptarnauti. Todèl būtina nustatyti, kaip išlaidų kaita priklauso nuo parinkto vagonų skaičiaus. Toki priklausymą nusako sąlyginis vagonų skaičius, kurio reikšmė nustatoma pagal funkcija, parodytą 3.6 pav.

Ši funkcija, rodanti išlaidų padidejjimą didinant vagonų skaičių sąstate, tinka visoms traukoms. Ji didejja pagal linijini priklausomumą.

Ne mažiau svarbu pagal galimybes Lietuvos geležinkelių tinkle parinkti ir tinkamiausią trauką. Pagal parko struktūrą ir galimą naudoti trauką šiuo metu (matyt, ir ateityje) bus naudojamos dvi traukos rūšys: elektrinè ir šiluminè. 


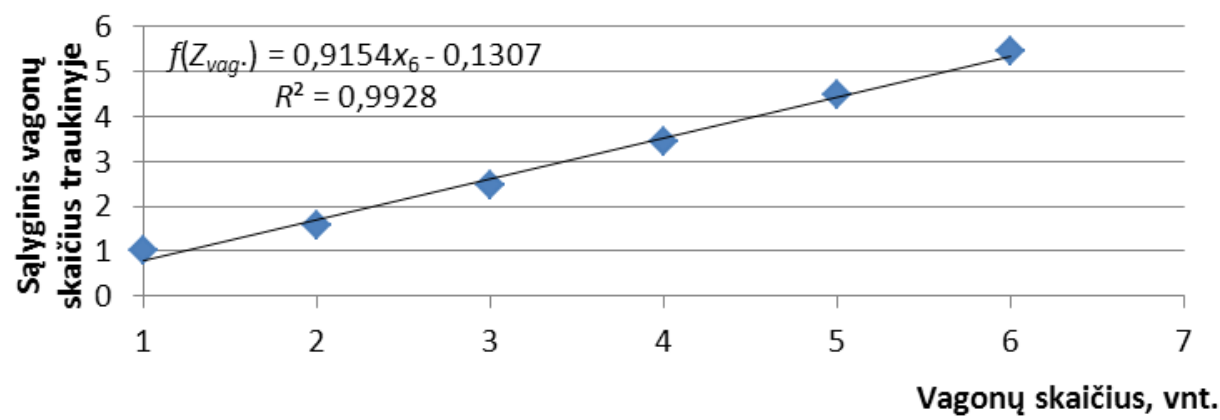

3.6 pav. Sąlyginis vagonų skaičius

Fig. 3.6. Conditional number of carriages

Pagrindinius ruožus, t. y. Kena-Klaipèda ir Kena-Kaliningradas, numatoma visiškai elektrifikuoti, nes tai yra tranzitiniai krovinių vežimo keliai, duodantys didžiausią ekonominę naudą, o kituose vietiniuose ruožuose bus naudojama trauka, kur pirminis energijos šaltinis yra šiluminis variklis. Tokiai traukai priskiriamos automotrisès, dyzeliniai traukiniai ir keleiviniai šilumvežiai (atskiras lokomotyvas). Pagal visus techninius ekonominius rodiklius ir ekologinius parametrus pati tinkamiausia yra elektrinè trauka. Todèl paèmus elektrinę trauką kaip pagrinda, t. y. kaip vieneta, visų kitų naudojimas gali būti išreikštas išlaidų padidejjimo koeficientu.

Šių koeficientų reikšmès pateiktos 3.3 lentelejje, o jų kitimo priklausymas 3.5 pav.

Iš pateiktų duomenų galima pastebèti vienos ar kitos naudojamos traukos ekonomini efektyvumą. Pvz., naudojant šiluminę trauką keleiviniams sąstatams, lyginant su elektrine, sąnaudos išauga beveik pusantro karto $(1,44)$. Taigi traukos eiliškumą pagal ekonominị kriterijų ir nusako 3.3 lentelès turinys.

3.3 lentelè. Išlaidų padidèjimo koeficientų reikšmès pagal traukas

Table 3.3. Expenditure ratio values, depending on traction

\begin{tabular}{|c|l|c|}
\hline $\begin{array}{c}\text { Eil. } \\
\text { Nr. }\end{array}$ & \multicolumn{1}{|c|}{ Trauka } & Koeficientas \\
\hline 1 & Elektrinè trauka & 1 \\
\hline 2 & Automotrisé & 1,06 \\
\hline 3 & Dyzelinè trauka & 1,08 \\
\hline 4 & Šiluminè trauka (atskiras lokomotyvas) & 1,44 \\
\hline
\end{tabular}




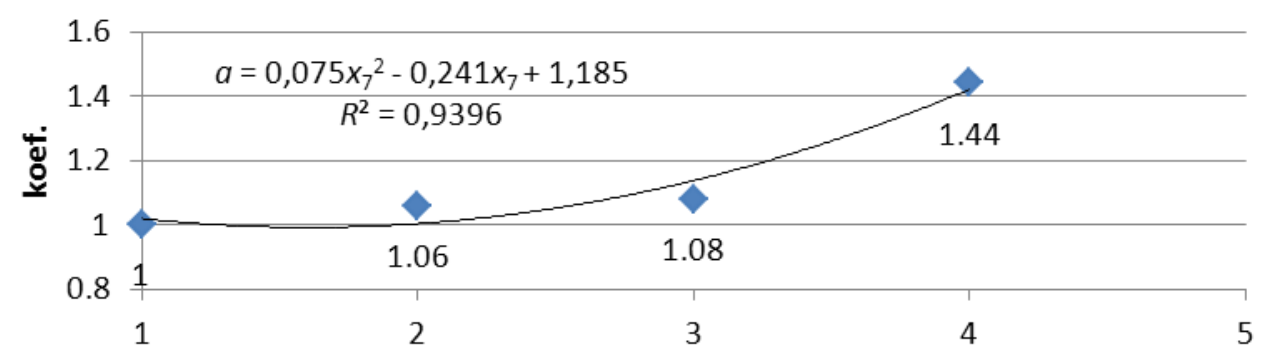

3.7 pav. Traukos koeficientas

Fig. 3.7. Traction coefficient

Taigi sustačius 3.2-3.7 pav. matematines išraiškas i (3.1, 3.3), gaunama tokia pajamų, išlaidų ir jų skirtumo išraiška:

$$
\begin{aligned}
& \Delta=P-I=\sum_{i=1}^{m} P-\sum_{j=1}^{n} I=\left\{\begin{array}{l}
k_{k p} \times P_{i} \times K\left(x_{1}\right)+k_{\text {dot }}\left(V \times L_{\text {reis }} \times I_{m} \times\left(1+\frac{r}{100}\right)\right. \\
\left.-k_{k} \times P_{i} \times K\left(x_{1}\right)-I_{k}\right)+k_{\text {komp }} \times I_{k}
\end{array}\right\} \times \frac{1}{L_{\text {reis }}}- \\
& {\left[\left(\left(\frac{E_{k e l}}{R_{k e l}}+\frac{E_{k t}}{R}\right) \times \frac{R_{1}}{R_{\text {kel }}}+\left(\frac{I_{k e l}}{A_{k e l}}+\frac{I_{k t}}{A}\right) \frac{A_{k e l}}{R_{k e l}}+\frac{I_{k o n t}}{R_{k e l}}\right)\right.}
\end{aligned}
$$

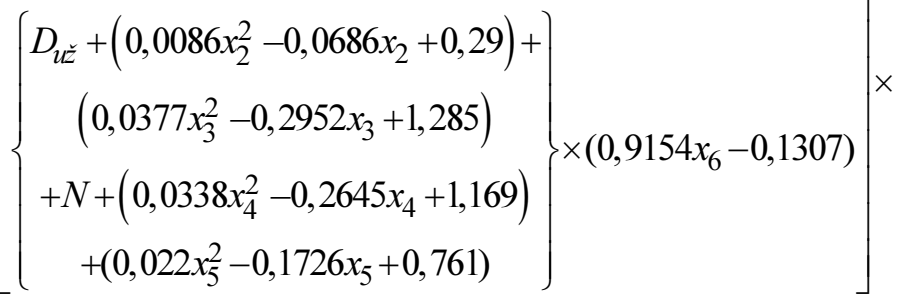

$\left(0,075 x_{7}^{2}-0,241 x_{7}+1,185\right)$

Uždavinys (3.1)-(3.3) buvo išspręstas tiesiogiai (nekeičiant jų regresijos priklausomybėmis) taikant pagrindinius tikslo funkcijos kintamuosius $M, D_{t}, R_{k}$, $K_{i s ̌}$. Šiu dviejų tikslo funkcijų optimizavimo rezultatai beveik sutapo, o tai rodo, kad optimizavimo uždavinys (3.4) gali būti taikomas prognozuojant būsimas reikšmes.

Šio modelio optimalių sprendinių paieškai pritaikomas matematinis optimizavimo metodas. Tuo tikslu analizuojami dažniausiai praktikoje taikomi metodai. 


\subsection{Optimizavimo metodų analizè}

Dažnai tenka spręsti optimizavimo uždavinius, kai ieškomos kokios nors funkcijos optimalios (didžiausios arba mažiausios) reikšmès bet kurioje kintamujų aibeje. Svarbiais ir sudètingais atvejais stengiamasi uždavini suformuluoti tiksliai ir ji spręsti tinkamais metodais. Optimizavimo (ekstremumo) uždavinius nagrinejja matematinès analizès nesąlyginio ir sąlyginio ekstremumo, funkcijos didžiausiujjų ir mažiausiujų reikšmių radimas uždaroje srityje, taip pat speciali matematine disciplina - sprendimo teorija ir metodai, vadinami matematiniu programavimu (Čiočys, Jasilionis 1990; Žilinskas 1999). Šis terminas buvo pasirinktas todèl, kad sukurtieji metodai buvo skirti optimaliam ekonominių, transporto ir kitų sričių veiklos programų sudarymui. Matematinis programavimas susideda iš atskirų optimizavimo metodų: tiesinio, netiesinio programavimo, dinaminio bei stochastinio programavimo, taip pat matricinio lošimo teorijos ir daugiakriterinių metodų. Kiekvienas metodas turi savo privalumų ir trūkumų, todèl sprendžiant praktinius uždavinius konkretaus metodo pasirinkimas priklauso nuo taikomo optimalumo kriterijaus, nuo kintamujų apribojimo pavidalo, sprendimą priimančio asmens kvalifikacijos ir vertinimo tikslo. Praktikoje optimizavimas gali prasidèti nuo paprasčiausių metodų taikymo ir surinkus papildomą informacija, igijus profesionalumo ir atitinkamas kompiuterines programas pereinama prie tobulesnių ir sudètingesnių optimizavimo metodų.

Toliau trumpai aprašomi optimizavimo metodai, kuriuos galima pritaikyti sprendžiant šio darbo uždavinị.

Iš žinomų ir praktikoje taikomų optimizavimo metodų išsiskiria vadinamieji daugiakriterinio optimizavimo metodai. Daugiakriterinis optimizavimas tiesiogiai nepriklauso matematinio programavimo uždaviniams, tačiau yra nesudètingas ir pastaruoju metu plačiai taikomas praktikoje. Daugiakriteriniai vertinimo metodai taikomi pasirenkant vieną geriausią alternatyvą iš kelių pasiūlytujuc, pavyzdžiui, geriausią projekta, technologiją, imonę ir pan. (Ustinovičius, Zavadskas 2004; Zavadskas, Kaklauskas 1996).

Daugiakriterinių metodų pagrindą sudaro rodiklių $R_{i}(i=1,2, \ldots, m)$, apibūdinančių lyginamus objektus (alternatyva) $A_{j}(j=1,2, \ldots, n)$, statistinių duomenų arba ekspertų vertinimų sprendimo prièmimo matrica $R=\left\|r_{i j}\right\|$ ir rodiklių reikšmingumai (svoriai) $\omega_{i}(i=1,2, \ldots, m)$, čia $m$ - rodiklių skaičius, $n$ - lyginamų objektų (alternatyvų) skaičius. Vertinimo tikslas - taikant kiekybinius daugiakriterinius metodus, ranguoti lyginamus objektus $A_{j}$ tyrimo tikslo atžvilgiu ir pasirinkti vieną ar keletą geriausių alternatyvų. Taikant kiekybinius daugiakriterinius vertinimo metodus nustatoma, kokio pavidalo - maksimizuojamojo arba minimizuojamojo - yra kiekvienas rodiklis. Geriausios 
maksimizuojamujų rodiklių reikšmès - didžiausios, minimizuojamujų - geriausios reikšmès mažiausios. Kiekybinių daugiakriterinių metodų kriterijai dažniausia sujungia rodiklių bedimenses (normalizuotas) reikšmes $\tilde{r}_{i j}$ ir rodikliu svorius $\omega_{i}$.

Rodiklių, apibūdinančių tiriamaji objektą, nagrinejjamam tikslui įtaka nevienoda, todèl nustatyti rodiklių reikšmingumą (svorius) yra labai svarbus etapas. Dažniausiai taikomas vadinamasis subjektyvusis vertinimas, kai rodiklių svorius nustato specialistai ekspertai, nors žinomi objektyvūs ir apibendrinti vertinimai.

Atskirų ekspertų nuomonès (vertinimai) dažnai nesutampa, o gali būti ir prieštaringi, t. y. skiriasi atskirų ekspertų vertinimų rodiklių svarbumas ir prioritetiškumas. Vertinimai priklauso nuo ekspertu kvalifikacijos, darbo specifikos, susidomejjimo rezultatais, darbo stažo ir pan. Specialistų nuomonès apie santykini rodiklių svarbumą ir prioritetiškumą paprastai skiriasi, todèl rodiklių svorius kaip apibendrintus ekspertų nuomonių vidurkius, galima taikyti daugiakriteriniam vertinimui, jei nustatytas ekspertų vertinimų neprieštaringumas, t. y. ịrodyta, kad nuomonès yra statistiškai suderintos (Podvezko 2005).

Teorijoje ir praktikoje žinomi keli ekspertų rodiklių svarumo vertinimo būdai: rodiklių rangavimas, tiesioginis svorių vertinimas procentais arba vieneto dalimis, netiesioginiai vertinimai, rodiklių porinio lyginimo metodai

Pasaulyje žinoma ir taikoma daug skirtingų daugiakriterinų metodų - SAW, TOPSIS, COPRAS, VIKOR, PROMETHEE, ELECTRE ir kt. (Ustinovičius, Zavadskas 2004; Zavadskas, Kaklauskas 1996).

Kiekvienas daugiakriterinis metodas turi savo privaluma, ypatumą. Praktiškai ne vieną metodą negalima pritaikyti formaliai, iš karto. Dauguma metodų naudoja skirtingą specifinę pradinių duomenų normalizaciją arba duomenu transformaciją. Dažniausiai kiekybiniai daugiakriteriniai metodai sujungia $\mathfrak{i}$ vieną dydị metodo vertinimo kriterijaus rodiklių normalizuotas (bedimenses) reikšmes ir rodiklių svorius. Didžiausia (arba mažiausia) metodo kriterijaus reikšmė ir nustato geriausią alternatyvą.

Kaip pavyzdi galima pamineti SAW (angl. Simple Additive Weighting) metodą - tipini, žinomiausią ir dažniausiai praktikoje taikomą metodą. Metodo kriterijus $S_{j}$ tiksliai atspindi kiekybinių daugiakriterinių metodų idèją - rodiklių reikšmių ir jų svorių sujungimą i vieną dydi - metodo kriterijų.

Skaičiuojama visų rodikliu pasvertų normalizuotų reikšmių suma $S_{j}$ kiekvienam $j$-ajam objektui (alternatyvai). Ji nustatoma pagal formulę:

$$
S_{j}=\sum_{i=1}^{m} \omega_{i} \tilde{r}_{i j}
$$


čia: $\omega_{i}-i$-tojo rodiklio (kriterijaus) svoris; $\tilde{r}_{i j}-i$-tojo rodiklio normalizuota reikšmè $j$-ajam objektui.

$S A W$ metodas taiko duomenų normalizaciją:

$$
\begin{gathered}
\tilde{r}_{i j}=\frac{r_{i j}}{\sum_{j=1}^{n} r_{i j}}, \\
\left(\sum_{j=1}^{n} \tilde{r}_{i j}=1\right) .
\end{gathered}
$$

Geriausią variantą atitinka didžiausia kriterijaus $S_{j}$ reikšmè. Lyginamuosius variantus reikia išdėstyti (ranguoti) mažejančia tvarka.

Visi kriterijai (rodikliai) turi būti maksimizuojamieji, t. y. geriausia rodiklio reikšmè - didžiausia: tik tada turi prasmę rodiklių reikšmių su svoriais sujungimas į vieną dydi $S_{j}$.

Mūsų uždaviniui daugiakriterinio optimizavimo metodą galimą būtų taikyti, jei matematiškai sprendžiama problema būtų užrašyta kitaip, t. y. būtų pasiūlytas kriterijų (rodikliu), charakterizuojančių optimizavimo uždavini, sąrašas, nustatytų kriterijų reikšmingumas (svoriai) ir iš kelių galimų veiklos alternatyvu̧, pvz., pervežimo projektų variantų, reikètų pasirinkti geriausią.

Keliu kintamuju funkciju nesalyginis ekstremumas. Nagrinejjama keliu kintamuju funkcija (tikslo funkcija) $y=f\left(x_{1}, x_{2}, \ldots, x_{n}\right)$. Reikia rasti šios funkcijos lokaluji ekstremuma, t. y. maksimumo arba minimumo taškus, ir suskaičiuoti funkcijos reikšmes šiuose taškuose. Žinoma (Pekarskas 1996; Žilinskas 1999), kad jei taškas $M\left(\tilde{x}_{1}, \tilde{x}_{2}, \ldots, \tilde{x}_{n}\right)$ yra funkcijos $y=f\left(x_{1}, x_{2}, \ldots, x_{n}\right)$ ekstremumas, tai šitame taške funkcijos dalinès išvestinès lygios nuliui, t. $\mathrm{y}$.

$$
\left\{\begin{array}{l}
\frac{\partial f\left(x_{1}, x_{2}, \ldots, x_{n}\right)}{\partial x_{1}}=0, \\
\frac{\partial f\left(x_{1}, x_{2}, \ldots, x_{n}\right)}{\partial x_{2}}=0, \\
\ldots \\
\frac{\partial f\left(x_{1}, x_{2}, \ldots, x_{n}\right)}{\partial x_{n}}=0 .
\end{array}\right.
$$


Sistema (3.7) praktiniuose uždaviniuose būna netiesinè ir gali būti išspręsta taikant kompiuterines programas. Tai būtina ekstremumo sąlyga. Nesąlyginio lokaliojo ekstremumo teorija sudaro pagrindą ir kituose optimizavimo uždaviniuose, yra toliau nagrinejamų optimizavimo metodų sudedamoji dalis.

Keliu kintamuju funkciju salyginis ekstremumas. Sąlyginio ekstremumo matematinis uždavinys formuluojamas taip. Tarkime, reikia rasti funkcijos $y=f\left(x_{1}, x_{2}, \ldots, x_{n}\right)$ ekstremumus, kai kintamieji susieti tam tikra lygtimi:

$$
\varphi\left(x_{1}, x_{2}, \ldots, x_{n}\right)=0 .
$$

Ši lygtis vadinama ryšio lygtimi, o funkcijos $y=f\left(x_{1}, x_{2}, \ldots, x_{n}\right)$ ekstremumai, kurie tenkina šią lygti, vadinami sąlyginiais. Geometriškai lygtis (3.6) apibrèžia kintamuju $x_{1}, x_{2}, \ldots, x_{n}$ erdvèje kreivę $L$ (nebūtinai uždaraja). Tokiu atveju funkcijos $y=f\left(x_{1}, x_{2}, \ldots, x_{n}\right)$ ekstremumas ieškomas ne visuose kintamujų erdvejje, bet kreivès (3.6) taškuose.

Norint rasti sąlyginius ekstremumus, sudaroma Lagranžo funkcija: $L\left(x_{1}, x_{2}, \ldots, x_{n}, \lambda\right)=f\left(x_{1}, x_{2}, \ldots, x_{n}\right)+\lambda \varphi\left(x_{1}, x_{2}, \ldots, x\right)$, čia $\lambda$ - Lagranžo daugiklis.

Kaip ir nesąlyginio lokaliojo ekstremumo atveju, jei taškas $M\left(\tilde{x}_{1}, \tilde{x}_{2}, \ldots, \tilde{x}_{n}\right)$ yra funkcijos $y=f\left(x_{1}, x_{2}, \ldots, x_{n}\right)$ lokaliojo salyginio ekstremumo taškas, tai egzistuoja toks realusis skaičius $\lambda_{0}, \mathrm{kad}$

$$
\left\{\begin{array}{l}
\frac{\partial L\left(x_{1}, x_{2}, \ldots, x_{n}, \lambda\right)}{\partial x_{1}}=\frac{\partial f\left(x_{1}, x_{2}, \ldots, x_{n}\right)}{\partial x_{1}}+\lambda \frac{\partial \varphi\left(x_{1}, x_{2}, \ldots, x_{n}\right)}{\partial x_{1}}=0, \\
\frac{\partial L\left(x_{1}, x_{2}, \ldots, x_{n}, \lambda\right)}{\partial x_{2}}=\frac{\partial f\left(x_{1}, x_{2}, \ldots, x_{n}\right)}{\partial x_{2}}+\lambda \frac{\partial \varphi\left(x_{1}, x_{2}, \ldots, x_{n}\right)}{\partial x_{2}}=0, \\
\frac{\partial L\left(x_{1}, x_{2}, \ldots, x_{n}, \lambda\right)}{\partial x_{n}}=\frac{\partial f\left(x_{1}, x_{2}, \ldots, x_{n}\right)}{\partial x_{n}}+\lambda \frac{\partial \varphi\left(x_{1}, x_{2}, \ldots, x_{n}\right)}{\partial x_{n}}=0, \\
\frac{\partial L\left(x_{1}, x_{2}, \ldots, x_{n}, \lambda\right)}{\partial \lambda}=\varphi\left(x_{1}, x_{2}, \ldots, x_{n}\right)=0 .
\end{array}\right.
$$

Dèl to, kad (3.8) kreivè gali būti neuždara, sprendžiant praktinius uždavinius prie šios sąlygos papildomai taikomi kintamujų apribojimai. Šiuo atveju tai bus didžiausiosios ir mažiausiosios kelių kintamujų funkcijų reikšmès radimas uždaroje srityje. Toks uždavinys sprendžiamas taikant gradiento metodus. 
Didžiausiosios ir mažiausiosios keliu kintamuju funkciju reikšmès radimas uždaroje srityje. Tai dažniausiai praktikoje sprendžiamas uždavinys. Nagrinèjama kelių kintamujų funkcija $y=f\left(x_{1}, x_{2}, \ldots, x_{n}\right)$. Reikia apskaičiuoti šios funkcijos didžiausiają ir mažiausiają reikšmes srityje $D$, apribotoje uždaraja kreive $L$. Taškai, kuriuose funkcija $y=f\left(x_{1}, x_{2}, \ldots, x_{n}\right)$ igyja didžiausiają ir mažiausiają reikšmes, yra vidiniai srities $D$ taškai arba kreivès $L$ taškai.

Norint rasti funkcijos $z=f(x, y)$ mažiausiają ir didžiausiają reikšmes, reikia (Pekarskas 1996; Žilinskas 1999):

1. Rasti funkcijos $y=f\left(x_{1}, x_{2}, \ldots, x_{n}\right)$ stacionariuosius taškus, priklausančius sričiai $D$, ir apskaičiuoti funkcijos $y=f\left(x_{1}, x_{2}, \ldots, x_{n}\right)$ reikšmes šiuose taškuose.

2. Rasti kreivès $L$ taškus, kuriuose funkcija igyja sąlyginius ekstremumus ir apskaičiuoti funkcijos $y=f\left(x_{1}, x_{2}, \ldots, x_{n}\right)$ reikšmes šiuose taškuose.

3. Iš visų gautų funkcijos reikšmių išrinkti didžiausiają ir mažiausiają reikšmę.

Šis uždavinys lengvai sprendžiamas ir dažnai taikomas praktikoje, kai sritis $D$ yra stačiakampis gretasienis kintamuju $x_{1}, x_{2}, \ldots, x_{n}$ erdveje, t. y. kiekvienas iš kintamuju $x_{i}$ kinta atitinkamose atkarpose $\left[x_{i(\min )}, x_{i(\max )}\right]$. Šiame darbe bus ieškomas netiesinės tikslo funkcijos ekstremumas su tiesiniais kintamujų apribojimais.

Tiesinis programavimas. Tiesinis programavimas yra paprasčiausias ir dažniausiai praktikoje taikomas matematinio programavimo uždavinys, kai ir tikslo funkcija ir kintamujų apribojimai yra tiesinès funkcijos kintamujų atžvilgiu, nes daugelis praktikoje kylančių uždavinių yra tiesiniai.

Tiesinio programavimo matematinis uždavinys formuluojamas taip (Čiočys, Jasilionis 1990; Žilinskas 1999):

Tarkime, reikia rasti tiesinès funkcijos

$$
f\left(x_{1}, x_{2}, \ldots, x_{n}\right)=c_{1} x_{1}+c_{2} x_{2}+\ldots+c_{n} x_{n}
$$

minimumą, kai yra šios sąlygos:

$$
\left\{\begin{array}{l}
a_{11} x_{1}+a_{12} x_{2}+\ldots+a_{1 n} x_{n} \geq b_{1} \\
a_{21} x_{1}+a_{22} x_{2}+\ldots+a_{2 n} x_{n} \geq b_{2} \\
\ldots \\
a_{m 1} x_{1}+a_{m 2} x_{2}+\ldots+a_{m n} x_{n} \geq b_{m}
\end{array}\right.
$$




$$
x_{j} \geq 0, j=1,2, \ldots, n \text {. }
$$

Uždavinys gali būti užrašytas kompaktiškai, rasti:

$$
\min \sum_{j=1}^{n} c_{j} x_{j},
$$

kai yra šios sąlygos:

$$
\begin{gathered}
\sum_{j=1}^{n} a_{i j} x_{j} \geq b_{i} \quad(i=1,2, \ldots, m), \\
x_{j} \geq 0, j=1,2, \ldots, n .
\end{gathered}
$$

Kintamuju $x_{j}(j=1,2, \ldots, n)$ reikšmès, tenkinančios apribojimų sistemą, vadinamos tiesinio programavimo uždavinio leistinuoju sprendiniu.

Tiesinio programavimo uždavinys gali būti suformuluotas, maksimizuojant tikslo funkciją (pvz., pelną), rasti:

$$
\max \sum_{j=1}^{n} c_{j} x_{j},
$$

kai yra šios sąlygos

$$
\begin{gathered}
\sum_{j=1}^{n} a_{i j} x_{j} \leq b_{i} \quad(i=1,2, \ldots, m), \\
x_{j} \geq 0, j=1,2, \ldots, n .
\end{gathered}
$$

Tiesinio programavimo uždavini galima išspręsti, taikant bendrujų matematinio programavimo, vadinamojo netiesinio programavimo, metodus, tačiau lengviau pritaikyti specialius metodus, sukurtus tiesiniam programavimui, pvz., Simpleks metodą. Mūsų atveju galima taikyti tiesinio programavimo metodą, kai uždavinio tikslo funkcija yra tiesinè kintamujų atžvilgiu. Tai būtų supaprastintas mūsų uždavinio variantas.

Netiesinis programavimas. Kai praktinis optimizavimo uždavinys, kaip ir mūsų atveju, yra sudètingesnis, ne visada tikslo funkciją ir kintamujų apribojimų lygtis galima aprašyti tiesinèmis lygtimis. Jei bent viena iš uždavinio srities apribojimo funkcijų yra netiesinè, toks optimizavimo uždavinys vadinamas netiesinio programavimo uždaviniu. 
Netiesinio programavimo matematinis uždavinys formuluojamas taip.

Rasti tikslo funkcijos $f\left(x_{1}, x_{2}, \ldots, x_{n}\right)$ minimuma, t. y.:

$$
\min f\left(x_{1}, x_{2}, \ldots, x_{n}\right)
$$

leistinoje srityje, apibrèžtoje funkcijų $g_{i}\left(x_{1}, x_{2}, \ldots, x_{n}\right)$ nelygybès arba lygybès nuliui reikalavimais, t. y.:

$$
\begin{gathered}
g_{i}\left(x_{1}, x_{2}, \ldots, x_{n}\right) \leq 0, i=1,2, \ldots, k, \\
g_{i}\left(x_{1}, x_{2}, \ldots, x_{n}\right)=0, i=k+1, k+2, \ldots, m .
\end{gathered}
$$

Netiesinio programavimo uždavinys dažniausiai sprendžiami gradientiniu nusileidimo metodu, taikant būtiną ekstremumo sąlyga, t. y. jei taškas $M\left(\tilde{x}_{1}, \tilde{x}_{2}, \ldots, \tilde{x}_{n}\right) \quad$ yra funkcijos $y=f\left(x_{1}, x_{2}, \ldots, x_{n}\right) \quad$ ekstremumo taškas, tai jame funkcijos gradientas lygus nuliui. Kaip žinoma, funkcijos gradientas yra vektorius iš jos dalinių išvestinių, t. $y$.:

$\operatorname{grad} f\left(x_{1}, x_{2}, \ldots, x_{n}\right)=\left(\frac{\partial f\left(x_{1}, x_{2}, \ldots, x_{n}\right)}{\partial x_{1}}, \ldots, \frac{\partial f\left(x_{1}, x_{2}, \ldots, x_{n}\right)}{\partial x_{n}}\right)$.

Nusileidimo metodai yra iteraciniai. Pradedama nuo vartotojo parinkto taško $X_{0}=\left(x_{1}^{0}, x_{2}^{0}, \ldots, x_{n}^{0}\right)$ generuojama taškų seka $X_{i+1}=X_{i}+\gamma_{i} S_{i}$, čia $S_{i}$ yra gradiento (tiksliau, antigradiento) krypties (dažniausiai vienetinio ilgio) vektorius, $\gamma_{i}$ iteracijos žingsnio gana mažas daugiklis artejjant prie minimumo taško, žingsnio ilgis trumpejja.

Norint taikyti gradientinio nusileidimo metodą reikia aukšto vartotojų parengimo lygio ir taikymo atsargumo, net rastas taškas gali būti lokaliojo (ne globaliojo) minimumo bei balno taškas ir rezultatas priklauso nuo pradinio pasirinkto taško $M\left(\tilde{x}_{1}, \tilde{x}_{2}, \ldots, \tilde{x}_{n}\right)$.

Kadangi darbe pristatoma tikslo funkcija yra netiesine ir jos paskirtis - minimizuoti kintamujų (išlaidų) reikšmes, sprendinių paieškai bus taikomas šis metodas. Tam tikslui buvo pasirinkta programos MATLAB (angl. Matrix Laboratory) terpès paprogramè „fmincon“, skirta mažiausiujų reikšmių paieškai sprendžiant netiesines lygtis su daugeliu kintamujų ir apribojimais (priedas). 


\subsection{Matematinio modelio praktinis taikymas}

Toliau nagrinejjami trys būdingi keleivinių traukinių maršrutai, kuriems sudarytu modeliu bus parinkti racionaliausi riedmenu deriniai.

Reisas Klaipėda-Vilnius. Iš surinktų statistinių duomenų (3.2 lentelè) matyti, kad reiso pradžioje keleivių skaičius šiek tiek viršija 100, o nuo pusiaukelès (Radviliškio) sumažeja beveik per pusę. Grafinè pokyčio interpretacija pavaizduota 3.8 pav.

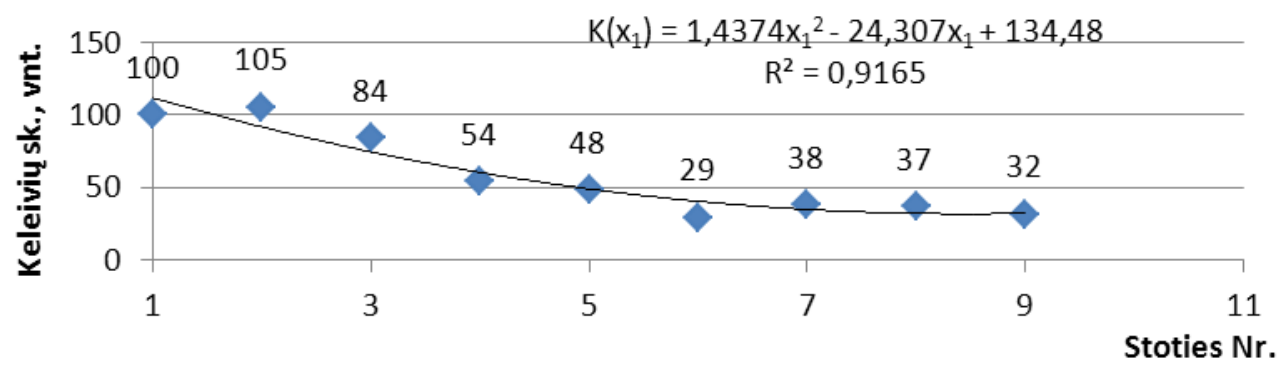

3.8 pav. Keleiviu srauto pokytis reise Klaipeda-Vilnius

Fig. 3.8. Change of passenger flow at the route Klaipeda-Vilnius

Čia ant abscisių ašies atidètos stočių lokalizacijos vietos reise nuo 1 iki 9 , kad būtų patogiau naudoti jas matematiniame modelyje, nustatant esamą keleivių skaičių traukinyje. Šios regresijos lygtys (3.2 lentelè) sudarytos remiantis pastarujų šešerių metų statistika. Visuose vietiniuose maršrutuose matomos keleivių skaičiaus mažèjimo tendencijos, tačiau per pastaruosius 2-3 metus (2.12 pav.) jis praktiškai stabilizuojasi ir vietiniais maršrutais pervežama apie 4,1 mln. keleivių. Tiesa, 2009 m. šis skaičius sumažèjo iki 3,6 mln., bet tam turèjo įtakos visuotinis ekonominis nuosmukis. Viena pagrindinių priežasčių, mažinant keleivių vežimo geležinkeliais nuostolius, yra mažas keleivių skaičius, nuo kurio priklauso gaunamų pajamų dydis. Todèl visais galimais būdais privalu didinti keliaujančiujjų skaičių geležinkeliais. Sunku tikètis didelio gyventojų prieaugio netolimoje perspektyvoje, tačiau nemažą keleivių skaičių, taikant komforto gerinimo priemones, galima prisivilioti iš kitų transporto rūšių pirmiausia iš automobilių transporto. Tai aprašyta ketvirtajame šio darbo skyriuje.

Sudarytos regresijos lygtys keleivių skaičiui prognozuoti maršrutuose turi išliekamają vertę tuo požiūriu, kad jeigu maršrutuose neịvyks didelių pokyčiu, pvz., neatsiras naujų traukos centrų, gamyklų, miestų ir pan., tai keleivių skaičius didès arba mažès visur maždaug tolygiai. Tam tikslui modelyje numatytas keleivių kaitos (proporcingumo) koeficientas $k_{p}$. 
Iš pateiktų duomenų matyti, kad maršruto pradžioje sąstatą turi sudaryti ne mažiau kaip du vagonai, o pusiaukelèje tikslinga vieną vagoną atkabinti. 3.4 lentelèje pateiktos suminis pelnas (nuostoliai) tarpstočiuose, apskaičiuotas naujai sudarytu modeliu.

3.4 lentelè. Tarpstočio pelnas (nuostoliai), apskaičiuotas sudarytu modeliu, Lt

Table 3.4. Mid-station profit (loss), calculated on the basis of the drafted model, in LTL

\begin{tabular}{|c|c|c|c|c|c|c|c|c|c|c|}
\hline $\bar{z}$ & 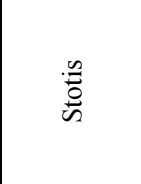 & 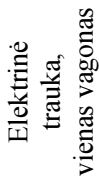 & 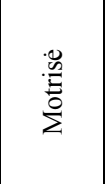 & 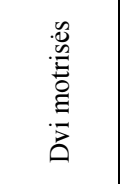 & 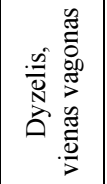 & 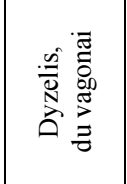 & 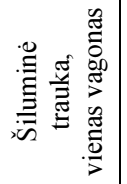 & 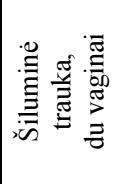 & 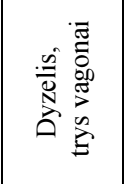 & 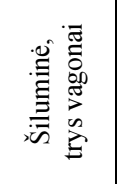 \\
\hline 1 & Klaipèda & & & 0 & & 0 & - & 0 & 0 & \\
\hline 2 & Kretinga & & & 3,52 & & $-22,66$ & - & $-78,32$ & $-294,36$ & $-417,56$ \\
\hline 3 & Plungé & & & $-61,84$ & & $-139,19$ & - & $-303,21$ & $-941,08$ & $-1305,08$ \\
\hline 4 & Telšiai & & - & $-144,16$ & - & $-254,83$ & - & $-489,41$ & $-1402,24$ & $-1923,04$ \\
\hline 5 & Šiauliai & & $-431,71$ & $-431,71$ & $-626,87$ & $-626,87$ & $-1040,37$ & $-1040,37$ & $-2649,00$ & $-3567,40$ \\
\hline 6 & Radviliškis & & $-394,71$ & $-530,11$ & $-595,47$ & $-749,27$ & $-1021,17$ & $-1212,97$ & $-3018,20$ & $-4048,60$ \\
\hline 7 & Kèdainiai & & $-310,87$ & $-878,91$ & $-530,19$ & $-1162,71$ & $-994,93$ & $-1799,21$ & $-4231,64$ & $-5620,44$ \\
\hline 8 & Jonava & & $-278,94$ & $-1056,54$ & $-507,25$ & $-1377,23$ & $-990,59$ & $-2091,85$ & $|-4828,70|$ & $-6391,10$ \\
\hline 9 & Kaišiadorys & $-248,94$ & $-248,94$ & $-1229,34$ & $-485,95$ & $-1585,73$ & $-987,29$ & $-2375,95$ & $|-5407,40|$ & $-7137,80$ \\
\hline 10 & Vilnius & $-177,92$ & $-178,59$ & $-1611,91$ & $-435,03$ & $-2048,03$ & $-976,57$ & $-3006,42$ & $|-6695,14|$ & $-8800,74$ \\
\hline
\end{tabular}

Nagrinejjant 3.4 lenteleje pateiktus duomenis, matyti, kaip galima mažinti nuostolius parenkant trauką ir vagonų skaičių. Šis maršrutas ypatingas tuo, kad pagal dabar esamą padèti galima naudoti šiluminę ir elektrinę traukas - nuo Klaipėdos iki Kaišiadorių šiluminę, o nuo Kaišiadorių iki Vilniaus - elektrinę. Modelis rodo minètas galimybes. Iš pateiktų duomenų matyti, kad naudingiausia būtų pradèti kelionę dviejų automotrisių deriniu iki Šiaulių, toliau tęsti kelionę viena automotrise iki Kaišiadorių, o nuo čia iki Vilniaus naudoti elektrinę trauką, t. y. sodinti keleivius į kursuojanti elektrinį traukinị Vilnius-Kaunas. Tokiu atveju galutiniai reiso nuostoliai sudarytų tik $178 \mathrm{Lt}$, naudojant vieną automotrisę nuo Šiaulių iki Vilniaus, nuostoliai būtų panašūs, naudojant dvi motrises visame ruože, nuostoliai padidètų iki 1612 Lt, o nuo Šiaulių persèdus i dyzelinį traukinị su vienu vagonu, nuostoliai siektų $435 \mathrm{Lt}$, atskiru šilumvežiu traukiamas keleivinis vagonas atsieitu 977 Lt. Visi kiti variantai yra gerokai nuostolingesni. Šiuo metu esančiai infrastruktūrai ir keleivinių riedmenų parkui būtų tikslinga naudoti dviejų automotrisių derini, vieną atkabinant nuo Šiaulių stoties. 
Pastaruoju metu šiame ruože kursuoja trijų vagonų traukinių sąstatai su šilumine ir dyzeline trauka. Nuostoliai, atsirandantys eksploatuojant tokius sąstatus, pavaizduoti 3.9 pav.

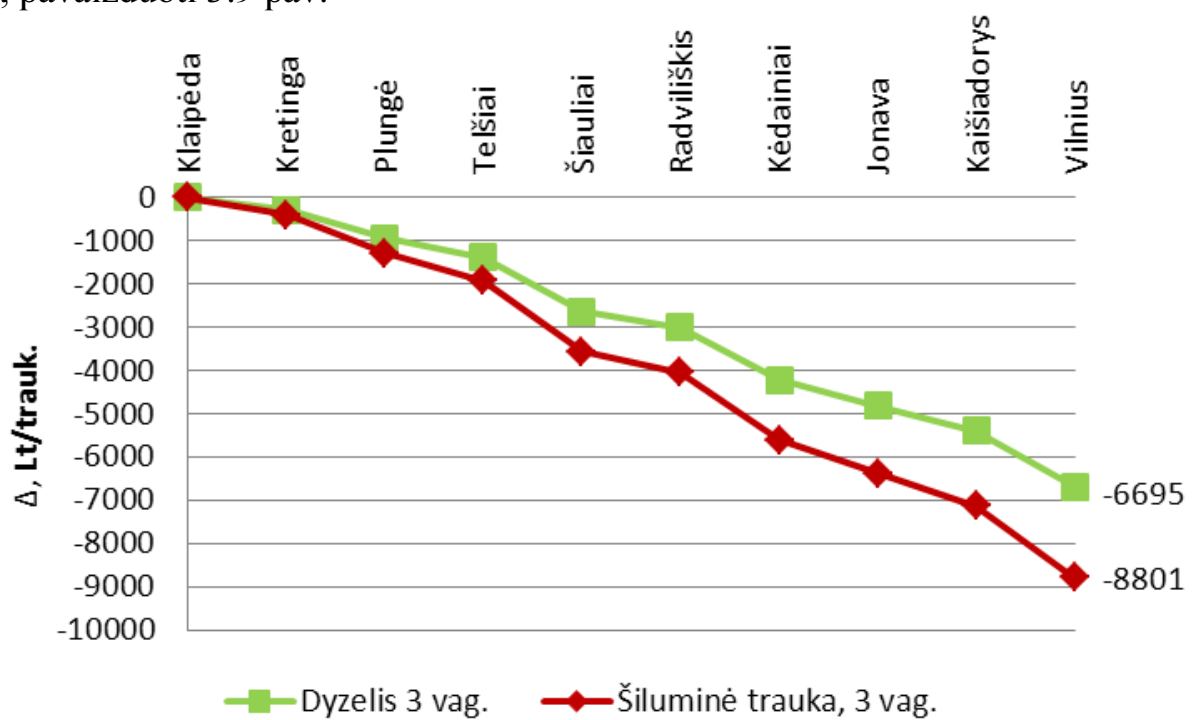

3.9 pav. Nuostoliu apskaičiavimas sudarytu modeliu reise Klaipeda-Vilnius, Lt/trauk.

Fig. 3.9. Calculation of losses on the basis of a drafted model for the route Klaipeda-Vilnius, LTL/train

Iš duomenų, pateiktų 3.4 lentelèje ir 3.9 pav., nesunku nustatyti, kad naudojant automotrisių trauką ir atkabinant vieną automotrisę Šiauliuose nuostolius dabar naudojamai dyzelinei traukai galima sumažinti iki 37 kartų, o šiluminei iki 49. Jeigu leistume dvi automotrises neatkabindami jų Šiaulių stotyje, tai nuostoliai sumažètų atitinkamai 4,2 ir 5,5 karto. Šis pavyzdys labai aiškiai iliustruoja keleivių vežimo priemonių naudojimo lankstuma, varijuojant sąstatų sudètimi ir trauka, kai iki minimumo sumažinamas neužimtų vietų skaičius ir pasinaudojama organizacinėmis galimybėmis (t. y. vagonu prikabinimas ir atkabinimas tarpstočiuose, keleiviu persodinimas i kitas priemones, naudojant stovimas vietas ir t. t.) formuojant atitinkamus racionalius sąstatus (keičiant ju sudètị ir trauka) maršruto viduje.

3.10 pav. pateikta grafinè interpretacija visų galimų sąstatų derinių Klaipèda-Vilnius reise pagal 3.4 lentelès duomenis. Matyti, kad ir kokie sąstatų ir traukų deriniai būtų imami, visi yra mažiau nuostolingi, lyginant su dabar eksploatuojamais. 


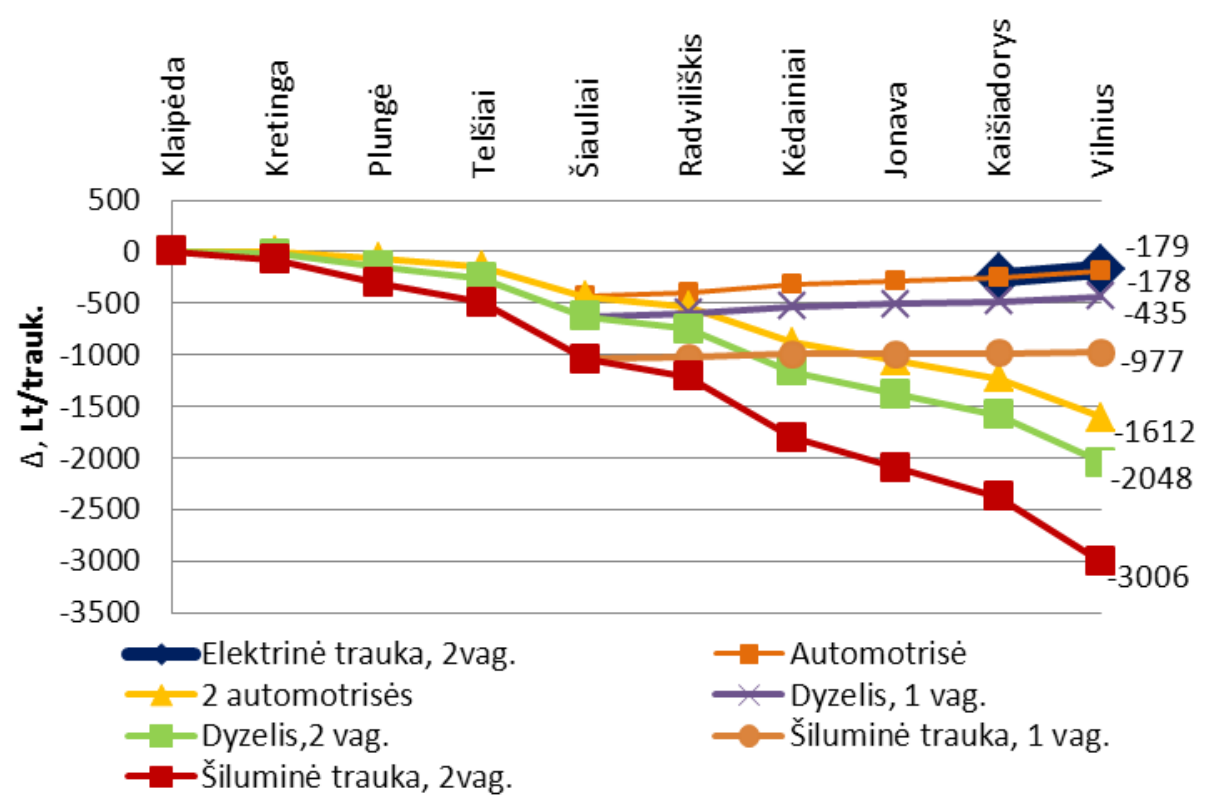

3.10 pav. Galimi deriniai ir pajamų (nuostolių) apskaičiavimas sudarytu modeliu reise Klaipėda-Vilnius, Lt/trauk.

Fig. 3.10. Possible combinations and calculation of incomes (losses) on the made up model for the route Klaipeda-Vilnius, LTL/train

Detaliai atskleisto modelio privalumas tas, kad galima varijuoti pajamų ir išlaidų sudedamosiomis dalimis, išryškinti silpniausias vietas (t. y. kur patiriama didžiausių nuostoliu ir kur juos galima mažinti) ir tiksliai bei kryptingai prognozuoti techninius, organizacinius bei ekonominius keleivinio parko parametrus, nuosekliai igyvendinti pirmojo būtinumo priemones, pvz., naujos technikos ịsigijima, keleivinių vagonu atkabinimo ir prikabinimo vietas, atitinkamus techninès priežiūros postus, eismo grafikų suderinamumą ir pan. 3.5 lentelejje pateikti duomenys rodo, kaip pakeičiant atskirus parametrus galima mažinti nuostolius reise Klaipèda-Vilnius nekeičiant dabartinès padèties, t. y. važiuojant trijų vagonų sąstatu su dyzeline trauka.

Atlikus pajamų didinimo galimybių analizę maršute pagal esamą padèti važiuojant trims vagonams dyzeline trauka, t. y. nedidinant keleivių skaičiaus reise (pagrindinių pajamų šaltini) ir nekeičiant vagonu skaičiaus, norint nepatirti šio reiso nuostolių $(\Delta=0)$, reikètuc varijuoti kitais komponentais, kaip parodyta 3.5 lenteleje. Tam tikslui reikia padidinti 1 kel. km ikaini 28 proc., gaunamas kompensacijas - 70 proc. ir sumažinti rinkliavą už naudojimąsi viešaja infrastruktūra 30 proc. 
3.6 lentelèje pateikti duomenys, kai visi kiti išlaidų duomenys paliekami tokie, kokie yra šiuo metu, didinamas tik keleivių, o kartu ir parduotų bilietų skaičius. Lentelès duomenys aiškiai rodo, kad reiso Klaipeda-Vilnius nuostolių riba būtų peržengta tik patrigubinus parduodamų bilietų skaičių arba, kas adekvatu, didinant parduodamų bilietų kainą trigubai. Tokiu būdu šis matematinis modelis leidžia ieškoti optimalių variantų kiekviename reise varijuojant ịvairiais išlaidų ir pajamų kriterijais, atsižvelgiant ị esamą geležinkelių tinklo padètị.

3.5 lentelè. Reiso Klaipèda-Vilnius pajamų didinimo (nuostolių mažinimo) galimybių analizė važiuojant trimis vagonais dyzeline trauka

Table 3.5. Income increase (loss reduction) options analysis using 3 carriages combination with diesel traction at the route Klaipeda-Vilnius

\begin{tabular}{|l|c|}
\hline \multicolumn{1}{|c|}{ Sudedamoji dalis } & Reikšmių pokytis, proc. \\
\hline 1 kel. km ikainis & +28 \\
\hline Dotacija, kompensacija & +70 \\
\hline $\begin{array}{l}\text { Mokestis už naudojimąsi viešaja geležinkelių infrast- } \\
\text { ruktūra (rinkliava) }\end{array}$ & -30 \\
\hline$\Delta$ & 0 \\
\hline
\end{tabular}

3.6 lentelè. Reiso Klaipèda-Vilnius pelnas (nuostoliai) vienam vag. km priklausomai nuo keleivių skaičiaus

Table 3.6. Profit (loss) per $1 \mathrm{train} / \mathrm{km}$ on the basis of passengers number at the route Klaipeda-Vilnius

\begin{tabular}{|c|c|}
\hline Keleivių skaičiaus padidejimas, kartais & $\begin{array}{c}\text { Vidutinès 1 trauk. km pelnas } \\
\text { (nuostoliai), } \mathrm{Lt}\end{array}$ \\
\hline 1,00 & $-17,52$ \\
\hline 1,50 & $-10,52$ \\
\hline 2,00 & $-6,52$ \\
\hline 2,50 & $-2,50$ \\
\hline 3,00 & 1,49 \\
\hline
\end{tabular}

Reiso Vilnius-Šeštokai analizè. Šiam reisui būdinga tai, kad vagonų užpildymas, t. y. keleivių skaičius, krinta pagal dèsni, pavaizduotą 3.11 pav. Matyti, kad galinèje stoteleje (Šeštokuose) išlipa tik 3 arba 1 keleivis. Pradedant nuo Kauno (4 stotis) nuostoliai reise labai didèja. Tačiau jeigu būtų naudojama elektrinè trauka iki Kauno (elektrifikuotas ruožas), o nuo Kauno imtų kursuoti automotrisè, nuostoliai sumažètų iki 10-15 kartų (3.7 lentelè). 


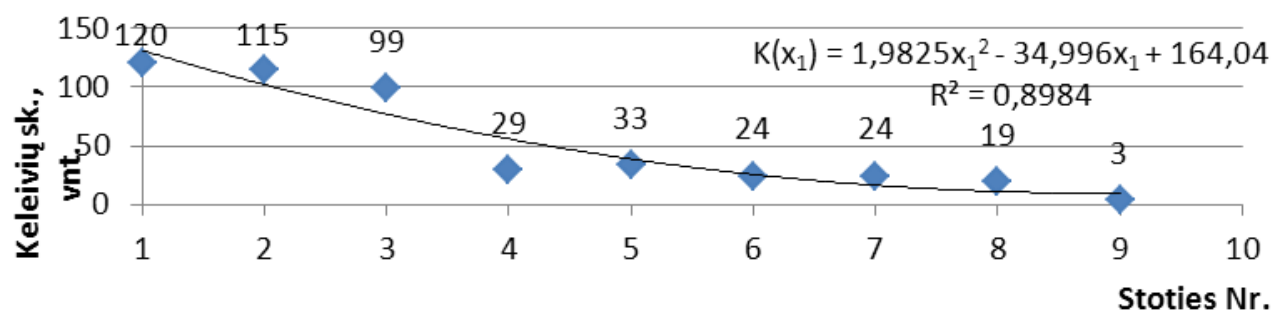

3.11 pav. Keleivių srauto pokytis reise Vilnius-Šeštokai

Fig. 3.11. Change of passenger flow at the route Vilnius-Šeštokai

3.7 lentelè. Tarpstočio pelnas (nuostoliai), apskaičiuotas sudarytu modeliu, Lt

Table 3.7. Mid-station profit (loss), calculated on the basis of the drafted model, in LTL

\begin{tabular}{|c|c|c|c|c|c|c|c|c|c|c|}
\hline & 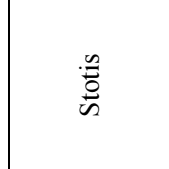 & 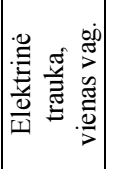 & 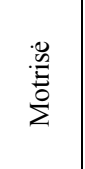 & 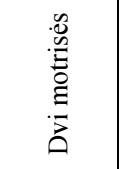 & 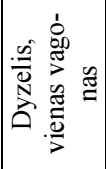 & 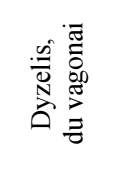 & 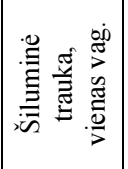 & 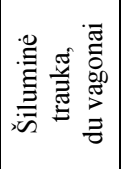 & 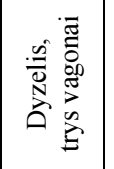 & 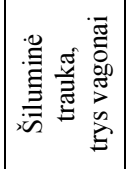 \\
\hline 1 & Vilnius & 0 & & 0 & - & & & 0 & & \\
\hline 2 & Lentvaris & 24,72 & & 21,12 & - & $-5,45$ & - & $-69,40$ & $-259,18$ & $-386,50$ \\
\hline 3 & Kaišiadorys & $-93,56$ & 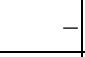 & $-107,25$ & - & $-208,24$ & - & $-451,31$ & $-1171,90$ & $-1655,66$ \\
\hline 4 & Kaunas & $-287,00$ & $-287,00$ & $-308,27$ & $-465,16$ & $-465,16$ & $-842,76$ & $-842,76$ & $-1747,65$ & $-2713,66$ \\
\hline 5 & Jūrè & & $-253,59$ & $-535,36$ & $-448,41$ & $-743,72$ & $-861,33$ & $-1230,40$ & $-2458,64$ & $-3641,75$ \\
\hline 6 & Kazlų Rūda & & $-255,57$ & $-592,57$ & $-453,90$ & $-811,82$ & \begin{tabular}{|l|}
$-874,26$ \\
\end{tabular} & $-1321,58$ & $-2618,58$ & $-3847,71$ \\
\hline 7 & Vinčai & & $-272,48$ & $-691,31$ & $-476,03$ & $-926,71$ & $-907,44$ & $-1470,70$ & $-2869,47$ & $-4166,79$ \\
\hline 8 & & & $-307,62$ & $-843,77$ & $-518,59$ & $-1102,27$ & $-965,96$ & $-1695,40$ & $-3239,92$ & $-4634,95$ \\
\hline 9 & Kalvarija & & $-351,14$ & $-1022,33$ & $-570,75$ & $-1307,55$ & $\mid-1036,52$ & $-1957,16$ & $-3669,52$ & $-5177,03$ \\
\hline & okai & & $-397,55$ & $-1212,56$ & $-626,34$ & $-1526,34$ & $-1111,66$ & $-2236,13$ & $-4127,33 \mid$ & $|-5754,69|$ \\
\hline
\end{tabular}

Iš pateiktos lentelès matyti, kad visų variantų rezultatai yra neigiami. Tačiau mažiausiai nuostolių duotų dvi automotrisès iš Vilniaus, vieną iš jų atkabinant Kaune, arba du dyzeliniai vagonai, iš kurių vieną taip pat atkabinant Kaune $(\Delta=-626 \mathrm{Lt})$.

Tačiau visais atvejais optimizavus ši maršrutą pagal vagonų skaičių ir trauką pasiekiamas pranašumas prieš dabar esamą padèti (3.12 pav.). Jeigu, pavyzdžiui, būtų leista šiuo maršrutu kursuoti dviejų vagonų dyzeliniam traukiniui, tai būtų 2,7 karto mažesni nuostoliai. 


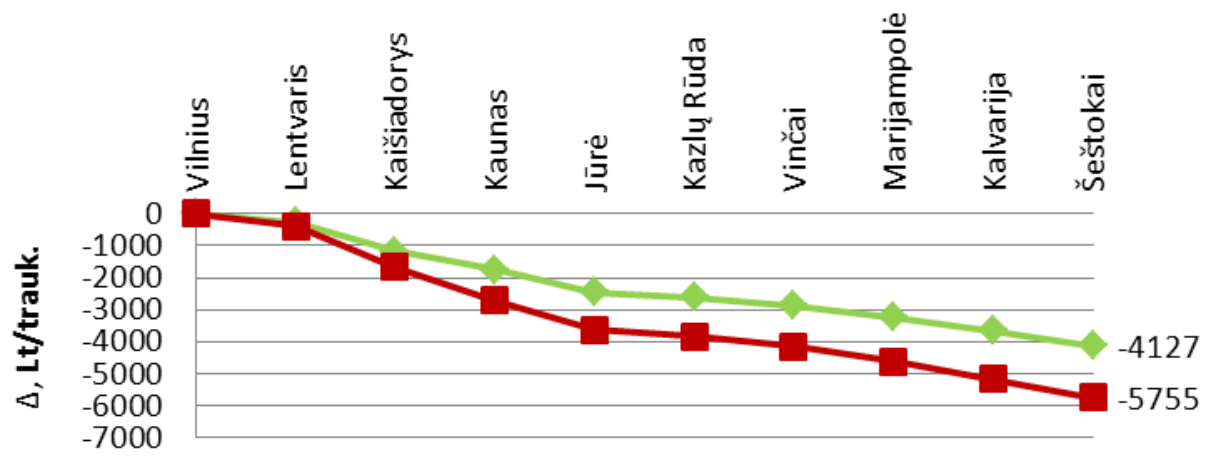

$\because$ Dyzelis 3 vag. $\quad \longrightarrow$ Šiluminè trauka, 3 vag.

3.12 pav. Reiso Vilnius - Šeštokai nuostolių apskaičiavimas sudarytu modeliu, Lt/trauk.

Fig. 3.12. Calculation of losses on the basis of a drafted model for the route Vilnius - Šeštokai, LTL/train

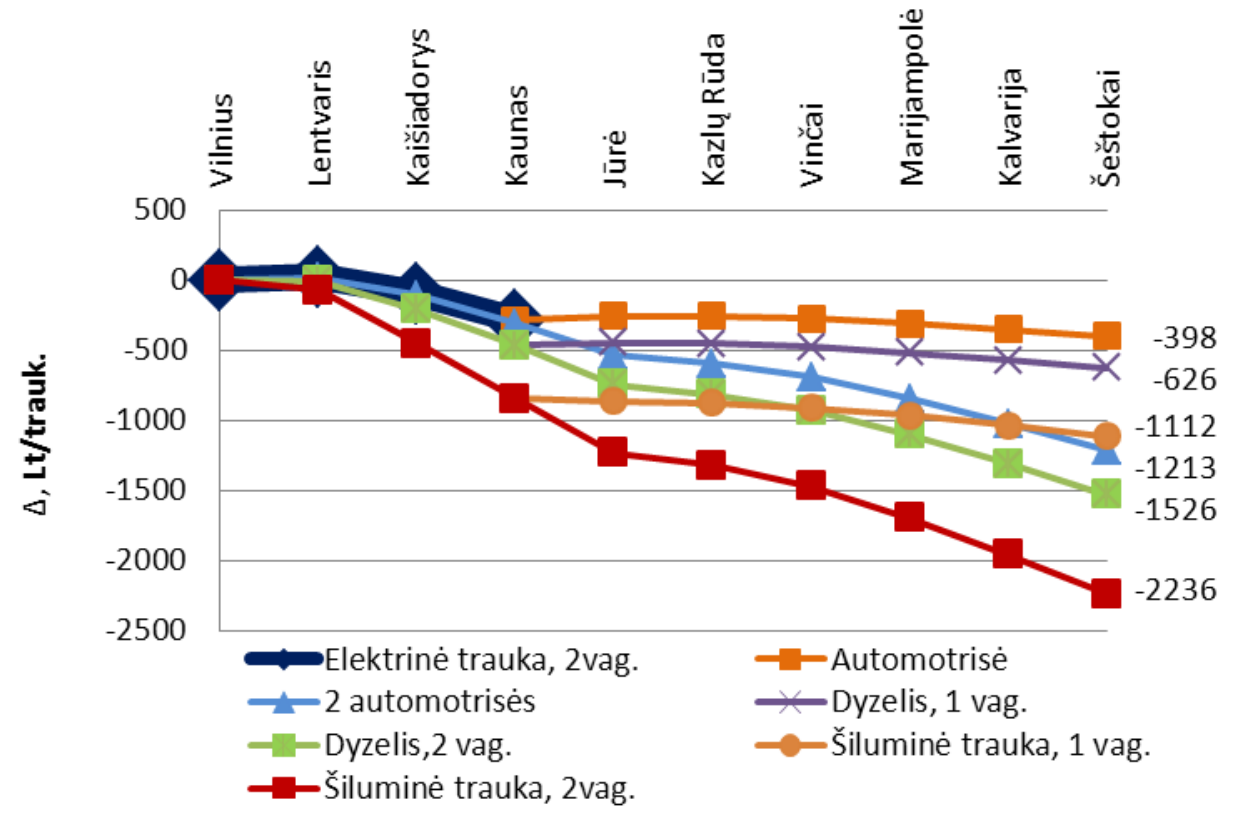

3.13 pav. Reiso Vilnius-Šeštokai galimi deriniai ir pajamų (nuostolių) apskaičiavimas sudarytu modeliu, Lt/trauk.

Fig. 3.13. Possible combinations and calculation of incomes (losses) on the made up model for the route Vilnius-Šeštokai, LTL/train 
3.13 pav. pavaizduotos visu galimų variantų pagal sąstato ilgị ir trauką ekonominiai rodikliai. Aiškiai matyti, kad keičiant trauką ir sąstatų ilgi gaunamas didelis ekonominis efektas. Pavyzdžiui, atkabinus Kaune vieną dyzelinį vagoną išlaidos sumažèja apie 6,6 karto. Tas pats būtų ir su šilumine trauka (šilumvežis plius du vagonai). Atkabinus vieną Kaune, išlaidos sumažèja apie 5 kartus. Tačiau ši trauka yra pati brangiausia, todèl jos ir nerekomenduotina naudoti nagrinejamam reisui.

Remiantis keleivių srautų didejjimo prognoze, 3.8 lentelëje pateikti galimi nuostolių (pajamų) rezultatai, važiuojant reisu Vilnius-Šeštokai trimis vagonais dyzeline trauka. Iš 3.8 lentelès duomenų matyti, kad analizuojant reiso VilniusŠštokai padèti, jeigu nekeičiama trauka ir sąstatų ilgiai, norint gauti tarp pajamų ir išlaidų nulinį balansą $(\Delta=0)$, reikètų rinkliavas už viešają geležinkelių infrastruktūrą mažinti 20 proc., dotacijas (kompensacijas) didinti 70 proc., paliekant tą patị 1 kel. km ịkaini.

3.8 lentelè. Reiso Vilnius-Šeštokai pajamų didinimo (nuostolių mažinimo) galimybių analizė važiuojant trimis vagonais dyzeline trauka

Table 3.8. Income increase (loss reduction) options analysis using 3 carriages combination with diesel traction at the route Vilnius-Šeštokai

\begin{tabular}{|l|c|}
\hline \multicolumn{1}{|c|}{ Sudedamoji dalis } & Reikšmiu pokytis, \% \\
\hline 1 kel. km ikkainis & 0 \\
\hline Dotacija, kompensacija & +70 \\
\hline $\begin{array}{l}\text { Mokestis už naudojimąsi viešaja geležinkelių infrastruktūra } \\
\text { (rinkliava) }\end{array}$ & -20 \\
\hline$\Delta$ & 0 \\
\hline
\end{tabular}

Kokie būtų gauti rezultatai padidinus keleivių (parduodamų bilietų) skaičių, parodyta 3.9 lentelèje. Matyti, kad nuostolių riba būtų peržengta padidinus keleivių skaičių daugiau kaip 2,5 karto.

Taigi visais atvejais matyti, kad geriausia išeitis - rasti techninių galimybių Kauno stotyje keisti sąstatų ilgius bei trauką. Sąstatų ir traukų deriniai turètų būti pagrindinè kryptis vežant keleivius šiuo maršrutu.

3.9 lentelè. Reiso Vilnius-Šeštokai pelnas (nuostoliai) 1 vag. km priklausomai nuo keleivių skaičiaus

Table 3.9. Profit (loss) per 1 train $/ \mathrm{km}$ on the basis of passengers number at the route Vilnius-Šeštokai

\begin{tabular}{|c|c|}
\hline Keleiviu skaičiaus padidejimas, kartais & Vidutinès 1 trauk. km pelnas (nuostoliai), Lt \\
\hline 1,00 & $-20,05$ \\
\hline 1,50 & $-11,29$ \\
\hline 2,00 & $-5,57$ \\
\hline 2,50 & 0 \\
\hline
\end{tabular}


Reiso Vilnius-Turmantas analizè. Šiam reisuimaršrutui taip pat būdingos visos šiuo metu Lietuvos geležinkelių tinkle naudojamos traukos, o reiso kelevių skaičius pasiskirsto tolygiai (3.14 pav.).

Atlikus pajamų ir išlaidų analizę tarpstočiuose ir visame reise, gauti rezultatai surašyti i 3.10 lentelę. Šiame reise naudoti mišriają trauką t. y. nuo stoties „Elektrodepas-1“ persodinti keleivius i automotrises arba dyzelini traukini organizaciniu, techniniu ir ekonominiu požiūriais netikslinga, nes gaunamos pajamos, lyginant su dviem automotrisemis arba dviem dyzeliniais vagonais, skiriasi labai mažai: pirmuoju atveju - 1,79 Lt, o antruoju - 14,79 Lt. Taigi, suskaičiavus laiko nuostolius persodinant žmones, taip pat įvertinus keleiviams sudarytus nepatogumus, toks variantas nèra pageidautinas.

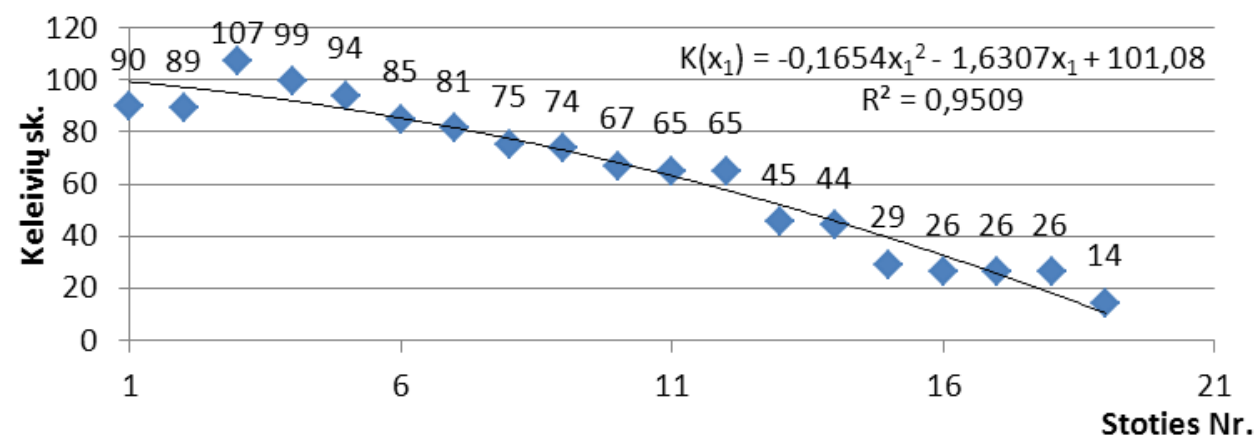

3.14 pav. Keleivių srauto pokytis reise Vilnius-Turmantas

Fig. 3.14. Change of passenger flow at the route Vilnius-Turmantas

3.10 lentelè. Tarpstočio pelnas (nuostoliai), apskaičiuotas sudarytu modeliu, Lt

Table 3.10. Mid-station profit (loss), calculated on the basis

of the drafted model, in LTL

\begin{tabular}{|c|c|c|c|c|c|c|c|c|c|c|}
\hline $\begin{array}{l}\dot{\vec{z}} \\
\dot{\overrightarrow{\mid}}\end{array}$ & $\frac{n}{0}$ & 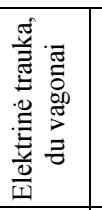 & 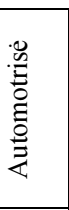 & 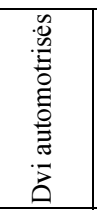 & 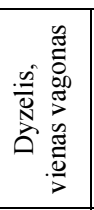 & 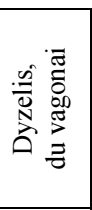 & 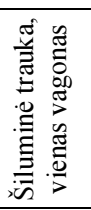 & 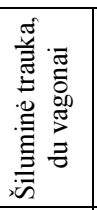 & 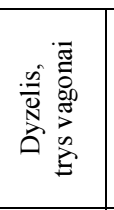 & 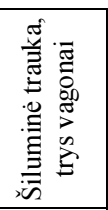 \\
\hline 1 & Vilnius & 0 & - & 0 & - & 0 & - & 0 & 0 & 0 \\
\hline 2 & Pavilnys & 31,3 & - & 30,45 & - & 24,25 & - & 9,35 & $-35,35$ & $-65,15$ \\
\hline 3 & Naujoji Vilnia & 54,66 & - & 53,13 & - & 41,97 & - & 15,15 & $-65,35$ & $-118,99$ \\
\hline 4 & Elektrodepas-1 & 70,54 & - & 68,75 & - & 55,75 & - & 24,41 & $-69,87$ & $-132,57$ \\
\hline 5 & Mickūnai & - & - & 90,25 & - & 69,85 & - & 22,86 & $-118,17$ & $-212,12$ \\
\hline 6 & Bezdonys & - & - & 115,27 & - & 80,47 & - & 2,97 & $-228,78$ & $-383,57$ \\
\hline 7 & Skersabaliai & - & - & 132,49 & - & 86,77 & - & $-13,83$ & $-314,32$ & $-515,1$ \\
\hline
\end{tabular}


2.10 lentelés pabaiga

\begin{tabular}{|c|c|c|c|c|c|c|c|c|c|c|}
\hline $\begin{array}{l}\dot{\vec{z}} \\
\dot{\overline{\mid}}\end{array}$ & $\stackrel{n}{0}$ & 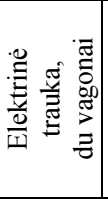 & 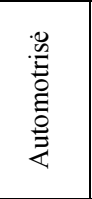 & 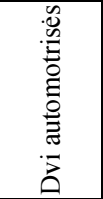 & 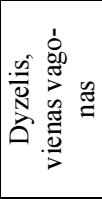 & 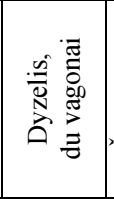 & 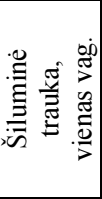 & 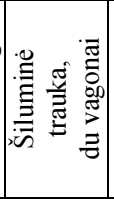 & 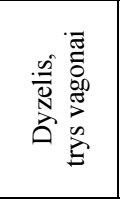 & 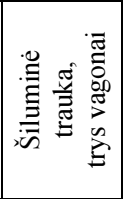 \\
\hline 8 & Santaka & - & - & 0 & - & 88,1 & - & $-35,6$ & $-404,83$ & $-651,67$ \\
\hline 9 & Pailgis & - & - & 153,1 & - & 90,82 & - & $-44,8$ & $-449,83$ & $-720,51$ \\
\hline 10 & Pabradè & - & 152,86 & 152,86 & 77,94 & 77,94 & $-84,48$ & $-84,48$ & $-569,27$ & $-893,39$ \\
\hline 11 & Pažeimene & - & 216,31 & 143,32 & 136,71 & 54 & $-35,52$ & $-138,93$ & $-714,44$ & $-1099,4$ \\
\hline 12 & Žeimena & - & 265,59 & 128,52 & 181,91 & 26,56 & 1,04 & $-193,17$ & $-848,44$ & $-1286,84$ \\
\hline 13 & Švenčionèliai & - & 316,29 & 97,42 & 227,41 & $-20,64$ & 35,54 & $-274,67$ & $-1031,64$ & $-1538,24$ \\
\hline 14 & Pakretuonė & - & 374,79 & 29,77 & 277,96 & $-113,19$ & 68,99 & $-420,02$ & $-1333,74$ & $-1945,49$ \\
\hline 15 & Ignalina & - & 398,79 & $-10,39$ & 297,88 & $-165,99$ & 80,27 & $-499,62$ & $-1493,1$ & $-2158,21$ \\
\hline 16 & Lobiniai & - & 416,19 & $-74,79$ & 310,08 & $-246,59$ & 81,37 & $-614,42$ & \begin{tabular}{ll|}
$-1709,7$ \\
\end{tabular} & $-2443,01$ \\
\hline 17 & Dūkštas & - & 422,07 & $-186,23$ & 308,4 & $-381,27$ & 63,87 & $-798,1$ & $-2039,26$ & $-2870,29$ \\
\hline 18 & Gerkonys & - & 419,97 & $-225,83$ & 303,95 & $-428,22$ & 54,37 & $-860,7$ & $-2148,66$ & $-3010,89$ \\
\hline 19 & Visaginas & - & 406,25 & $-294,78$ & 286,73 & $-508,02$ & 29,73 & $-963,6$ & $-2320,3$ & $-3228,59$ \\
\hline 20 & Turmantas & - & 371,15 & $-411,68$ & 246,43 & $-641,02$ & $-21,57$ & $-1130,9$ & $-2589,3$ & $-3565,79$ \\
\hline
\end{tabular}

Geriausia būtų iš Vilniaus išvažiuoti dviem automotrisėmis, o nuo Pabradès stoties vieną atkabinti. Tokiu atveju šiame reise pajamos viršytu išlaidas $371 \mathrm{Lt}$. Važiuojant su dviem automotrisèmis iki Turmanto, išlaidos viršytų pajamas 412 Lt. Panašus atvejis ir su dviejų vagonų dyzeliniu traukiniu - atkabinus vieną vagoną Pabradeje gaunamas $246 \mathrm{Lt}$ pelnas, o važiuojant iki Turmanto su dviem dyzelinio traukinio vagonais patiriama $641 \mathrm{Lt}$ nuostolių.

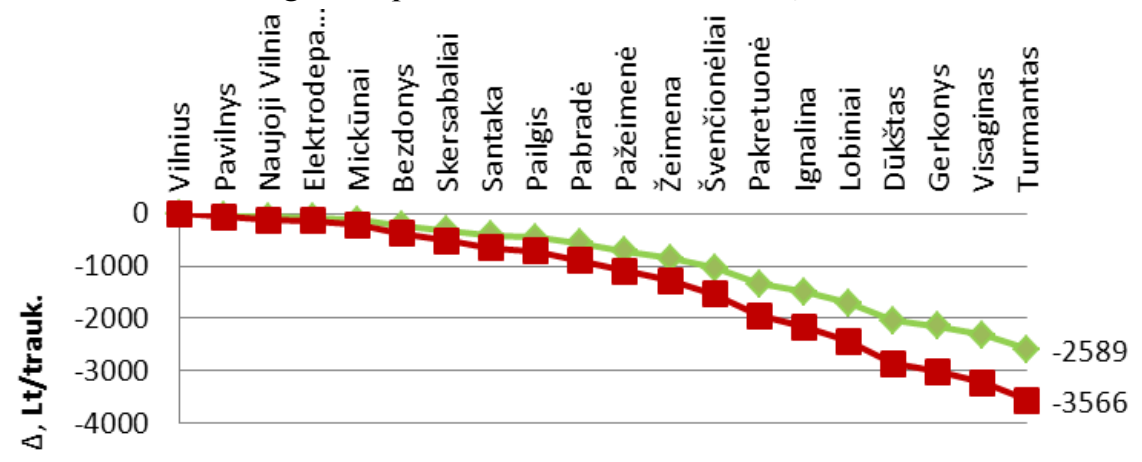

$\multimap$ Dyzelis 3 vag. $\quad \longrightarrow$ Šiluminè trauka, 3 vag.

3.15 pav. Reiso Vilnius-Turmantas nuostolių apskaičiavimas sudarytu modeliu, $\mathrm{Lt} /$ trauk.

Fig. 3.15. Calculation of losses on the basis of a drafted model for the route Vilnius-Turmantas, LTL/train 
Palyginus esamą padètị reise Vilnius-Turmantas (3.15 pav.) su optimizuoto maršruto galimybėmis, pastebima, kad naudojant dviejų ir vienos automotrisių derini vietoje dyzelinès traukos su trimis vagonais gaunamu $2589 \mathrm{Lt}$ nuostoliu galima gauti $371 \mathrm{Lt}$ pelno, o naudojant dyzelinių traukinių dviejų ir vieno vagono derini galima gauti 246 Lt pelno. Taigi šiame ruože tikslingiausia naudoti dviejų automotrisių sąstatą.

3.16 pav. parodyta ekonominè nauda visoms traukoms, kai Pabradès stotyje trumpinami traukiniai, t. y. atkabinami vagonai.

Žinoma, važiuojant priešinga kryptimi Turmantas-Vilnius Pabradeje vagonai turètų būti prikabinami. Taigi ir šiame reise tikslinga performuoti traukinius maršruto viduryje. Tam reikia sudaryti tinkamas technines galimybes.

Kaip ir anksčiau nagrinètuose reisuose, taip ir šiame - Vilnius-Turmantas, bandoma surasti pajamų ir išlaidų skirtumą, lygų nuliui $(\Delta=0)$, nekeičiant keleivių skaičiaus, o varijuojant kitais pajamų didinimo kriterijais. Optimizavimo rezultatai pateikti 3.11 lentelejje. Matyti, kad tam nekeičiant 1 kel. km įkainio, dotacijas reikètų padidinti 60 proc., o rinkliavas už naudojimąsi viešaja infrastruktūra sumažinti 20 proc.

Paliekant visus kitus pajamų didinimo veiksnius tuos pačius, norint peržengti nuostolių barjera, keleivių skaičių reikètų padidinti daugiau kaip 2 kartus.

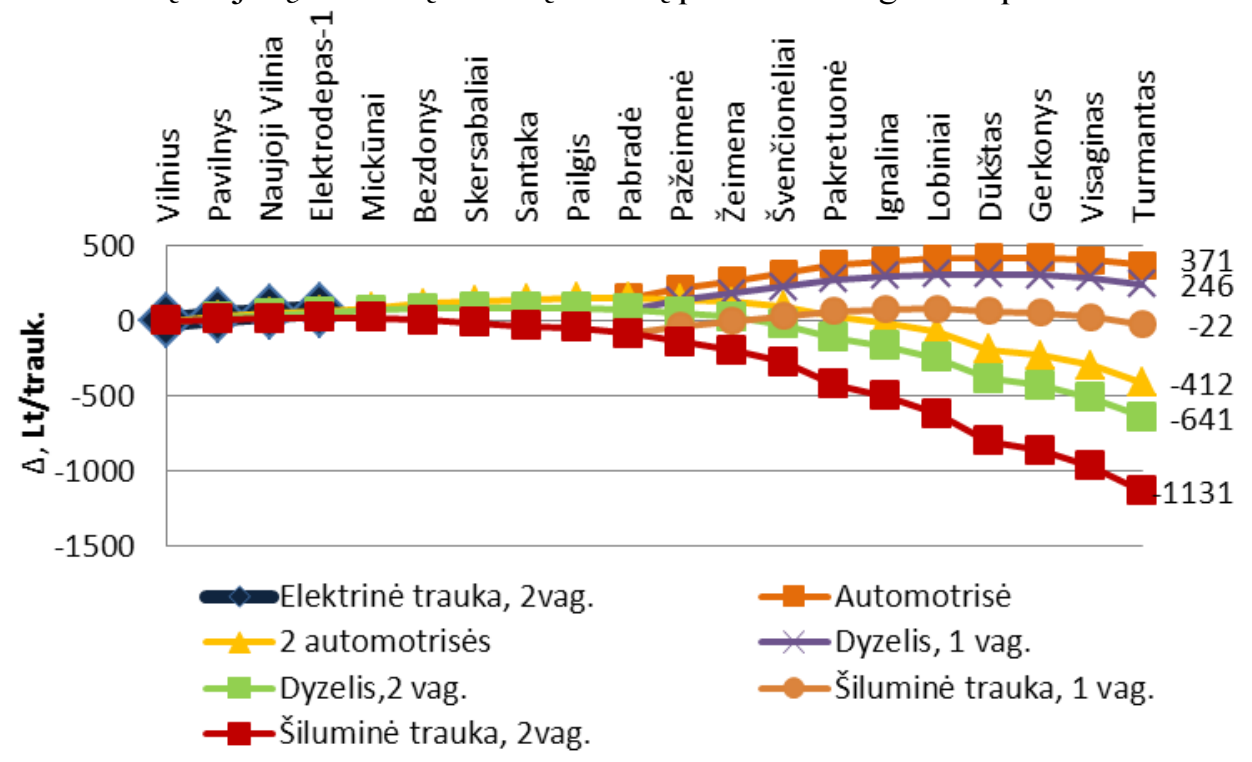

3.16 pav. Reiso Vilnius-Turmantas galimi deriniai ir pelno (nuostoliu) apskaičiavimas sudarytu modeliu, $\mathrm{Lt} /$ trauk.

Fig. 3.16. Possible combinations and calculation of incomes (losses) on the made up model for the route Vilnius-Turmantas, LTL/train 
3.11 lentelè. Reiso Vilnius-Turmantas pajamų didinimo galimybių analizė važiuojant trimis vagonais dyzeline trauka

Table 3.11. Income increase (loss reduction) options analysis using 3 carriages combination with diesel traction at the route Vilnius-Turmantas

\begin{tabular}{|l|c|}
\hline \multicolumn{1}{|c|}{ Sudedamoji dalis } & Reikšmé, \% \\
\hline 1 kel. km ịkainis & 0 \\
\hline Dotacija, kompensacija & +60 \\
\hline Mokestis už naudojimąsi viešaja geležinkelių infrastruktūra (rinkliava) & -20 \\
\hline$\Delta$ & 0 \\
\hline
\end{tabular}

3.12 lentelè. Reiso Vilnius-Turmantas pelnas (nuostolis) 1 vag. km priklausomai nuo keleiviu skaičiaus

Table 3.12. Profit (loss) per $1 \mathrm{train} / \mathrm{km}$ on the basis of passengers number at the route Vilnius- Turmantas

\begin{tabular}{|c|c|}
\hline $\begin{array}{c}\text { Keleivių skaičiaus padidejimas, } \\
\text { kartais }\end{array}$ & $\begin{array}{c}\text { Vidutinis 1 trauk./ km pelnas } \\
\text { (nuostoliai), Lt }\end{array}$ \\
\hline 1,00 & $-15,70$ \\
\hline 1,50 & $-9,49$ \\
\hline 2,00 & $-3,18$ \\
\hline 2,50 & 3,13 \\
\hline
\end{tabular}

Reise Vilnius-Turmantas nèra tikslinga naudoti elektrinę trauką, susijusią su nepatogumais persodinant keleivius Naujojoje Vilnioje, be to, trumpu atstumu ekonominis efektas nèra didelis (3.10 lentelè). Pats geriausias variantas iš Vilniaus išvykti dviem automotrisèmis, o nuo Pabradès vieną jų atkabinti. Tokiu atveju šio reiso pajamos viršytų išlaidas apie $371 \mathrm{Lt}$.

\subsection{Trečiojo skyriaus išvados}

1. Remiantis 2005-2009 m. surinktais stočių maršrutų statistiniais duomenimis buvo sudarytos 1, 2 ir 3 laipsnio keleivių skaičiaus kaitos regresijos lygtys (3.2 lentelè).

2. Sudarytas matematinis pajamų ir išlaidų modelis, leidžiantis įvertinti visus galimus pajamų ir išlaidų veiksnius bei minimizuoti kiekvieno maršruto sąnaudas, parenkant traukos rūši ir sąstatų ilgị.

3. Atlikus analizę, matematiniam priemonių parinkimo modeliui realizuoti pritaikytas netiesinių lygčių su daugeliu kintamujų ir apribojimais ekstremumo paieškos metodas.

4. Sudarytos atskirų išlaidų sudedamujų dalių kitimo regresijos lygtys per pastaruosius šešerius metus (3.2-3.5 pav.). 
5. Rastos koeficientų reikšmès, ivvertinančios naudojamą traukos rūšį modelyje (3.3 lentelè). Nustatyta, kad pigiausia yra elektrinè trauka, o brangiausia - šiluminè.

6. Realizuotas trijų būdingų keleivių maršrutu matematinis modelis: Klaipèda-Vilnius, Vilnius-Seštokai ir Vilnius-Turmantas. Jie parinkti todèl, kad galima realizuoti visas dabar naudojamas traukas Lietuvos geležinkeliuose.

7. Apskaičiuota, kad reisui Klaipėda-Vilnius, kai keleivių skaičius neviršija 100 , panaudojus dvi automotrises, galima sumažinti nuostolius, lyginant su dyzeline trauka, apie 4 kartus.

8. Apskaičiuota, kad reisui Vilnius-Šeštokai naudojant elektrinę trauką iki Kauno, o toliau paleidus 1 automotrisę, būtų gautas teigiamas pajamų ir išlaidų skirtumas $\Delta=398 \mathrm{Lt}$.

9. Pristatytu modeliu optimizuojant pajamas ir išlaidas galima varijuoti visais pajamų ir išlaidų parametrais, taip pat ir keleivių skaičiumi. Palikus anksčiau nagrinètuose ruožuose tas pačias traukos rūšis, norint vežti bent jau be nuostoliu, t. y. $\Delta \rightarrow 0$, reikètų padidinti keleivių skaičių nuo 2 iki 3 kartų.

10. Šis modelis praktikoje turètų būti taikomas dinamiškai, atsižvelgiant i pajamų ir išlaidų sudedamujų dalių pakeitimus ne tik žiemos ir vasaros periodais, bet ir švenčių dienomis, sudarytas sąlygas transformuoti maršrutų sąstatus ir keisti traukos rūšì. 



\section{4}

\section{Komforto gerinimo keleiviniuose traukiniuose veiksniai}

Skyriuje nagrinejamas vienas pagrindinių keleivių komforto gerinimo veiksnių vibracija. Skyriaus tematika paskelbti autoriaus straipsniai (Dailydka, Lingaitis, Myamlin, Prichodko 2008a; Dailydka, Lingaitis, Myamlin, Prichodko 2008b; Lingaitis, Dailydka, Myamlin, Prichodko 2008).

AB „Lietuvos geležinkeliai“ atliktos keleivių apklausos rezultatai objektyviai rodo pagrindines keleivių srautų didinimo ir jų vežimo sąlygų gerinimo veiklos kryptis. Svorio koeficientai, lemiantys keleivių skaičių, yra tokie:

- ilgas kelionès laikas - 0,42;

- trūksta komforto - 0,21 ;

- prastos stotys - 0,12 ;

- netinkami eismo tvarkaraščiai - 0,11 ;

- per brangūs bilietai - 0,09;

- blogas geležinkelio ir autobusų darbo koordinavimas - 0,03 ;

- kiti trūkumai - 0,02.

Iš apklausos rezultatų matyti, kad vienas svarbiausių veiksnių, darančių itaką keleivių srautams, yra vežimo geležinkeliu komfortas $(0,21)$. Ši teigini patvirtina ir AB „Lietuvos geležinkeliai“ ịsigytas komfortiškas elektrinis traukinys EJ 575 , kurio pirmujų metų eksploatacija parodè, kad keleivių srautai padidejo apie 
15 proc. Traukinys pasižymi aukštomis tolygaus eismo savybėmis, t. y. itin mažos vibracijos ir triukšmai salonuose. Šiame skyriuje bus tiriami minèti parametrai.

\subsection{Vibracijos poveikis keleiviams}

Vagonų vibracija sukelia ịvairiapusi poveikị keleiviams. Ji blogina keleivių savijauta, mažina juos aptarnaujančiojo personalo darbingumą. Todèl būtina ịvertinti vibracijos intensyvumą, atsižvelgiant i žalinga jos poveiki žmogui. Mažinant bendrą vibracijos lygị būtina atsižvelgti ị vibracijų dažnius, nes $4-8 \mathrm{~Hz}$ vibracijų dažniai itin žalingi žmogaus organizmui. Vibracijos ir triukšmo poveikis keleiviui lemia jo kelionès komforta, kuri nusako visas kompleksas parametrų - vibracijos dažnis ir amplitudè, triukšmo lygis, oro drègnumas bei temperatūra ir kt.

Praktiškai vertinant riedmenų vibracijos lygi, atsižvelgiant i keleivių patoguma, naudotasi Šperlingo tolygios eigos rodikliu (Оценка воздействия... 2000):

$$
W_{z}=0,896 c(f) \sqrt[10]{a^{3} f^{-1}},
$$

čia: $a$ - pagreičio amplitudè, $\mathrm{cm} / \mathrm{s}^{2} ; c(f)$ - dažnio ir vibracijos krypties koeficientas, veikiantis keleivio savijauta: $f$ - vibracijos dažnis, Hz.

Vibracijos dažnai nepaklūsta sinusoidiniam dèsniui, todèl eigos tolygumui ivertinti gali būti naudojama ir kita išraiška:

$$
W_{z}=0,896 \sqrt[10]{\sum_{i} \sum_{j} P_{i j} a_{i j}^{3} c^{10}\left(f_{j}\right) f^{-1}},
$$

čia: $i, j$ - intervalų indeksai, atitinkamai amplitudèms ir greitejjimo proceso skirtingų pusperiodžių dalims; $P_{i j}-i$-tojo intervalo ir $j$-osios dalies kartotinumas.

Remiantis (4.2) apskaičiuoti tolygios eigos rodikliai lyginami su standartine vertinimo skale (ISO 2631). Pagal lyginamuosius rezultatus galutinai įvertinama vagono važiuoklès kokybè.

4.1 lentelèje pateiktos $W_{z}$ koeficiento reikšmès, naudojamos tolygiai eigai vertinti.

Vibracija neigiamai veikia žmogaus klausa, regejjima, kraujotaka, nervų sistemą, taip pat smegenų veiklą. 
4.1 lentelè. Koeficiento $W_{z}$ reikšmès, naudojamos tolygiai eigai vertinti

Table 4.1. Values of coefficient $W_{z}$ used for evaluation of uniform motion

\begin{tabular}{|c|l|c|}
\hline $\begin{array}{c}\text { Eil. } \\
\text { Nr. }\end{array}$ & \multicolumn{1}{|c|}{ Eigos pobūdis } & $W_{z}$ reikšmé \\
\hline 1 & Labai gera & 2,0 \\
\hline 2 & Gera & $2,0-2,5$ \\
\hline 3 & Pakankama keleiviniams vagonams & $2,5-3,0$ \\
\hline 4 & Ribiné keleiviniams vagonams & $3,0-3,25$ \\
\hline 5 & Ribinè lokomotyvams & $3,5-3,75$ \\
\hline 6 & Ribinè atsižvelgiant ǐ žmogaus fiziologiją & 4,5 \\
\hline
\end{tabular}

Organai, tiesiogiai priimantys vibracija, skirstomi i dvi grupes. Pirmajai priklauso pusiausvyros organai (vestibulinis aparatas), kurie yra vidinejje ausyje. Sujungti atitinkamais ryšiais su smegenimis, jie veikia kaip suminis kampinių ir linijinių pagreičių matuoklis. Informacija, kurią pusiausvyros organai siunčia smegenims, vibracijos metu gali būti iškreipta, dezorientuojanti, o kai kuriais atvejais erzinanti ir sukelianti žmogui ligos būseną. Jejgos ir poslinkiai, sukelti vibracijos, slopinami daugybe mechaninių receptorių, esančių žmogaus organizme. Kai kurie iš jų, esantys raumenyse ir sausgyslèse, signalizuoja apie kūno padèti ir ji veikiančias jègas. Jie veikia kartu su ta centrinès nervu sistemos dalimi, kuri reguliuoja kūno padèti ir jo judesius. Šie receptoriai reaguoja i bet kokius pakitimus, taip pat ir i žemuosius dažnius.

Antrajai grupei priklauso receptoriai, kurie yra odoje ir jungiamuosiuose audiniuose bei atlieka jutimo (lytèjimo) funkcijas, reaguodami i aukštesnius dažnius (apie $30 \mathrm{~Hz}$ ). Vibracija tam tikrą poveiki daro organizmui per regèjimo ir klausos organus. Perduodant vibraciją nuo jos prideties vietos receptoriams, vieni dažniai sustiprinami, o kiti - susilpninami. 4.1 pav. pavaizduotas dažnio rodiklio $q=A_{1} / A_{2}$ (čia $A_{1}$ ir $A_{2}-$ kūno vertikaliujų vibracijų amplitudès atitinkamai galvos ir sėdynès lygyje) funkcijos kitimas galvos-juosmens sistemos plote.

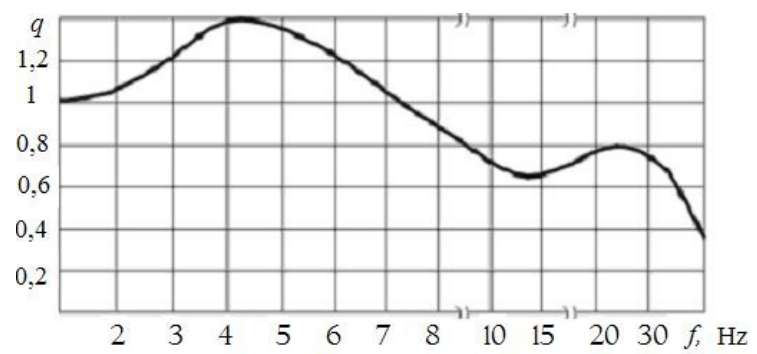

4.1 pav. Koeficiento $q$ kitimas nuo vibracijos dažnio $f$ funkcijos 
Fig. 4.1. Correlation between coefficient $q$ and the vibration frequency function $f$

Iš 4.1 pav. matyti, kad esant dažniu $4 \mathrm{~Hz}$, rodiklis $q=1,4$. Tai reiškia, kad vibracijos amplitudè galvos lygyje 40 proc. didesnè negu sèdynès.

Poveikis žmogui taip pat priklauso nuo vibracijos trukmès. Juo ji ilgesnè, tuo labiau pažeidžiamos fiziologinès organizmo funkcijos, be to, juo ilgiau veikè vibracija, tuo ilgiau reikia organizmui atsistatyti į normalią būklę.

\subsubsection{Vibracijos vertinimo kriterijai ir metodika}

Universaliais laikomi šie parametrai, apibūdinantys vibracijos poveiki žmogaus organizmui:

- vidutinis kvadratinis vibracijos pagreičio dydis, taip pat vibracijų amplitude;

- smūginio veikimo koeficientas, lygus maksimalios reikšmės ir vidutinès kvadratinès reikšmès santykiui. Jo dydis ne didesnis kaip 4;

- pagreičio kitimo intensyvumas, išreiškiamas $\left(\mathrm{m} / \mathrm{s}^{2}\right)^{2} / \mathrm{Hz}$

- vibracijos jautrumo izolinijos arba sédinčio keleivio tolygaus organizmo sužadinimo kreivès vertikaliomis vibracijomis;

- maksimalus žmogaus jautrumas vibracijoms 4-8 Hz diapazone, kai žmogaus organizme gali ịvykti rezonansas;

- tam tikro dažnio vibracijos trukmès poveikis organizmui, pvz., $1 \mathrm{~Hz}$.

Žmogaus organizmo būklès pokytị nuo vibracijos galima ịvertinti vibravimo energija $E$, perduota organizmui per laiką $T$ :

$$
E=v^{2} T|z|,
$$

čia $v$ ir $|z|$ - atitinkamai vibravimo greitis ir įeinančio impedanso modulis sužadinimo jègos pridèties taške.

Sandauga $v^{2}|z|$ yra galingumas, kuri sudaro aktyvioji dedamoji, sugeriama organizmo ir plintanti kaip šiluma, ir reaktyvioji, grižtanti i vibracijos šaltinị.

Vibracijos vertinimo kriterijumi galima naudoti sklaidos galingumą $Q_{R}$ :

$$
Q_{R}=\lim _{T \rightarrow \infty} \frac{1}{T} \int_{0}^{T} F(t) v(t) d t,
$$

čia $F(t)$ ir $v(t)$-jègos ir greičio pakitimai pagal laiko funkciją žmogaus kontakto vietoje su vibracijos šaltiniu.

Sudarant vibracijos vertinimo metodikas keleiviui labai svarbu, ką pasirinkti: atskiras dažnių juostas ar integralines visam dažnių diapazonui. Standartas 
ISO teikia pirmenybę integraliniam vertinimui, remiantis vibracijos jutimo izolinijomis.

Vibracijos poveiki žmogui galima pavaizduoti blokine schema, pateikta 4.2 pav.

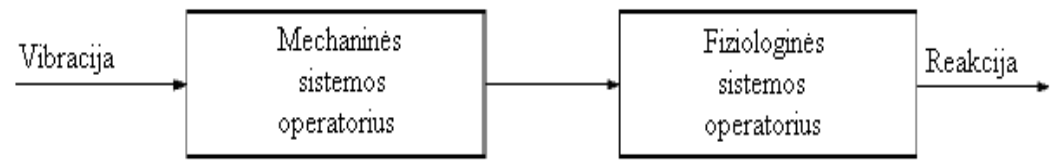

4.2 pav. Vibracijos poveikio žmogui blokinè schema

Fig. 4.2. Human exposure to vibration in block diagram

Čia vibracijos išreikštos nuosekliai mechaninès sistemos linijiniu operatoriumi ir nelinijiniu fiziologinès sistemos operatoriumi. Pagal šią metodiką poveikis organizmui vertinamas nustatant galvos pagreičius. raiška:

Reikia atsiminti, kad pagreičiai galvos ir sèdynès lygiuose yra susiję šia iš-

$$
S_{g}=S_{s} g_{r}(w),
$$

čia: $g_{r}(v)$ - santykio koeficiento modulis; $S_{g}, S_{s}$ - vidutiniai kvadratiniai pagreičiai atitinkamai galvos ir sėdynès lygyje.

Išraiška, pagal kurią nustatoma leidžiama vibracijos trukmė žmogaus organizmui, priklausomai nuo kūno vidutinio kvadratinio pagreičio sėdynès lygyje, atodo taip:

$$
\tau_{d}=\sum \varphi_{1} S_{\tau n}^{\alpha 1}, \min .
$$

čia: $\varphi_{1}$ - funkcija, priklausanti nuo pastovių koeficientų; $S_{\tau n}^{\alpha 1}-$ dažnio charakteristikos funkcija.

4.2 lentelejje pateiktos organizmui leidžiamos vibracijos trukmių reikšmès.

4.2 lentelè. Leidžiama vibracijos trukmè $\tau_{d}$ organizmui

Table 4.2. Allowed duration of vibration $\tau_{d}$ on the body

\begin{tabular}{|c|c|}
\hline$S_{s}, \mathrm{~m} / \mathrm{s}^{2}$ & $\begin{array}{c}\tau_{d}, \text { min., } \\
\text { pagal ISO standarta }\end{array}$ \\
\hline 0,12 & 1440 \\
\hline 0,18 & 960 \\
\hline 0,27 & 600 \\
\hline 0,315 & 480 \\
\hline 0,38 & 378 \\
\hline
\end{tabular}




\section{2 lentelès pabaiga}

\begin{tabular}{|c|c|}
\hline$S_{s}, \mathrm{~m} / \mathrm{s}^{2}$ & $\begin{array}{c}\tau_{d}, \text { min., } \\
\text { pagal ISO standarta }\end{array}$ \\
\hline 0,53 & 240 \\
\hline 0,71 & 150 \\
\hline 0,95 & 96 \\
\hline 1,18 & 60 \\
\hline 1,5 & 40 \\
\hline 1,8 & 25 \\
\hline 2,13 & 16 \\
\hline 2,36 & 10 \\
\hline 2,65 & 6,3 \\
\hline
\end{tabular}

Analogiška priklausomybė gali būti gauta naudojant empirinę formulę:

$$
\tau_{d}=10^{-3}\left(2,96 S_{s}^{0,827}+8,51+0,235 S_{s}^{6,33}\right) .
$$

\subsubsection{Leidžiami vibracijos parametrai}

Pateiktos mintys leidžia daryti išvadą apie tai, kad žmogaus organizmui labiausiai kenksmingi 4-8 Hz diapazono dažniai. 4.3 pav. pateiktos vertikalių vibracijų organizmo jutimo izolinijos.

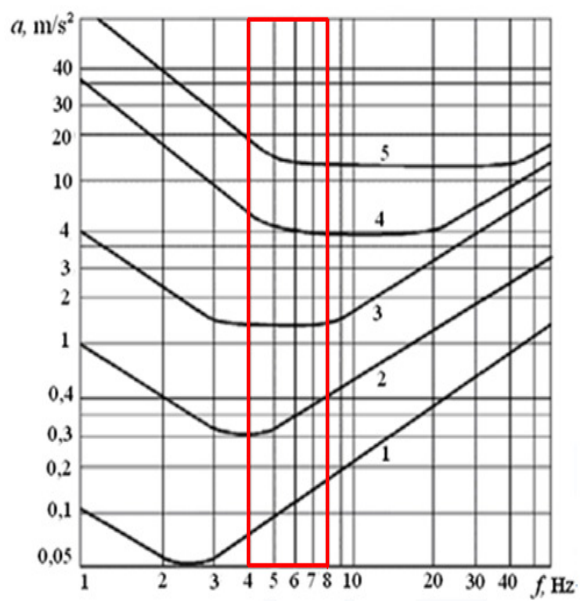

4.3 pav. Vertikalių vibracijų jutimo izolinijos: $a$ - pagreitis; $f$ - dažnis; 1 - vibracija nejuntama; 2 - vibracija juntama; 3 - vibracija juntama aiškiai; 4 - nemalonus poveikis;

5 - nepakeliamas poveikis

Fig. 4.3. Vertical vibration sensing contour lines: $\mathrm{a}$ - acceleration, $\mathrm{f}$ - frequency; 1 - imperceptible vibration; 2 - vibration felt; 3 - vibration felt clearly; 4 - nasty effect; 5 - severe impact 
4.4 pav. pateiktos kreivès, rodančios harmoninių virpesių trukmės ịtaką žmogaus būklei, veikiant $1 \mathrm{~Hz}$ dažniui.

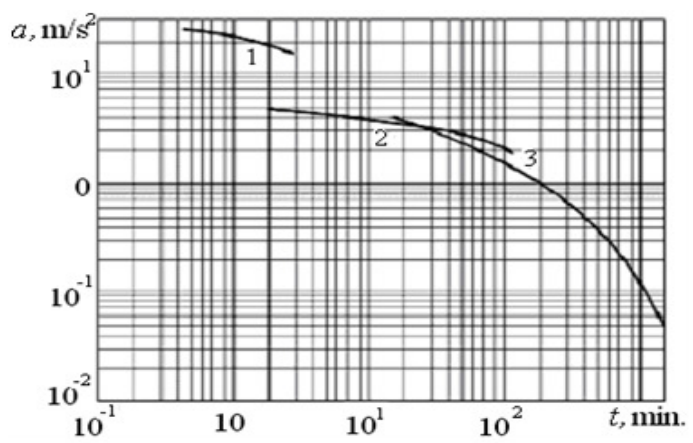

4.4 pav. Vibracijų trukmès įtaka žmogaus organizmo būklei, kai dažnis $1 \mathrm{~Hz}$ : $a$-pagreitis; $t$ - laikas; 1 - skausmo slenkstis; 2 - darbo našumo mažèjimas; 3 - bendras nuovargis

Fig. 4.4. Term influence of vibrations on the human body condition at a frequency of $1 \mathrm{~Hz}: \mathrm{a}$ - acceleration; $\mathrm{t}$ - time; 1 - the pain threshold; 2 - loss of productivity; 3 - the total fatigue

ISO standartų siūlomos vertikalių vibracijų jutimo izolinijos pavaizduotos 4.5 pav.

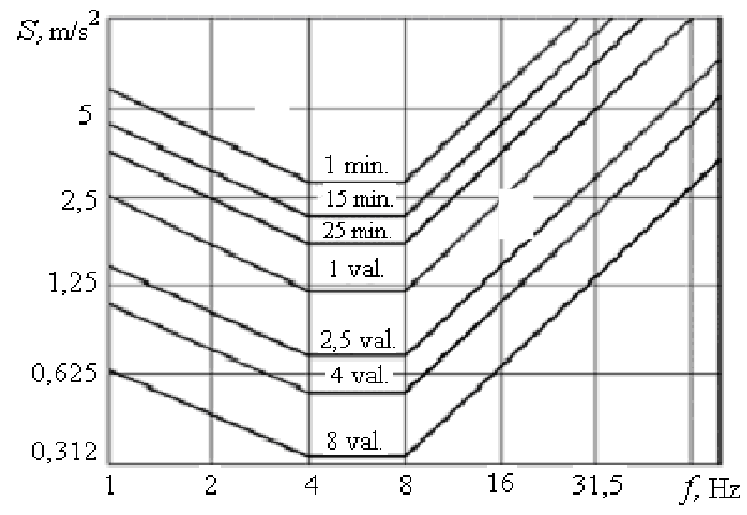

4.5 pav. Vertikalių vibracijų įtaka pagal ISO standartą:

$S_{s}$ - kūno pagreitis sėdynès lygyje; $f$ - dažnis

Fig. 4.5. Influence of vertical vibration in accordance with ISO standard:

$S_{s}$ - the seat body acceleration level, $f$ - frequency 
Pagal ši standartą esant vibracijai sėdynès lygyje ir pagreičiui $0,118 \mathrm{~m} / \mathrm{s}^{2}$, žmogui leidžiama trukmé siekia $1440 \mathrm{~min}$., $0,95 \mathrm{~m} / \mathrm{s}^{2}-96 \mathrm{~min}$., o kai pagreitis siekia $2,65 \mathrm{~m} / \mathrm{s}^{2}-$ ne ilgiau kaip $6,3 \mathrm{~min}$.

Viršijus šias normas, žmogus gali rimtai susirgti. Norint garantuoti būtiną komfortą keleiviniuose vagonuose, tolygios eigos koeficientas privalo būti $W_{Z}=2,0-2,5$.

Taigi, apibendrinus vibracijos poveiki žmogaus organizmui, t. y. jo sveikatai ir patogiai jausenai vagone, galima konstatuoti, kad vibracija yra sunkiausiai kontroliuojama ir sunkiai pasiekiamos leistinos jos normos vagonuose. Tai priklauso ne tik nuo vagonų konstrukcijos, bet ir nuo kelio kokybès. Pastarasis veiksnys yra pagrindinis virpesiu žadintuvas. Mechaniniai virpesiai slopinami ¿vairiausiomis techninemis-ergonominemis priemonèmis, tačiau svarbiausias elementas šioje sistemoje - važiuokliu pakabos. Norint parinkti techninius važiuoklių parametrus, kuriems esant tolygios eigos koeficientas neviršytų leistinojo $W_{Z}=2,0-2,5$, o leidžiama vibracijos trukmė ir pagreičiai neviršytų ribų, nurodytų 4.2 lentelèje, būtina, kad vežimèlių konstrukcijos turètų atitinkamus dinaminius ir stovumo koeficientus, važiuojant traukiniui maksimaliai leistinais greičiais.

Ši klausimą autorius tyrinèjo kartu su Ukrainos Kriukovo vagonų gamyklos specialistais konstruojant naujas pakabas greitaeigiams traukiniams. Tolesni tyrimai skirti minètai problemai spręsti.

\subsection{Keleivinių vagonų važiuokliụ pakabụ optimalių parametrų paieškos sąlygų nustatymas}

Kaip minèta (4.1 poskyris), vienas pagrindinių parametrų, sudarančių gerą komfortą keleiviui vagone, yra tolygios eigos koeficientas, kuris glaudžiai siejasi su vibracijos dažniais, pagreičiais ir amplitudèmis. Sumažinti vibraciją vagonuose galima ịvairiomis priemonemis, pvz., irengiant patogius, vibracijas slopinančius krèslus, parenkant atitinkamas konstrukcines vagonų medžiagas ir kt. Tačiau pagrindinis elementas, mažinantis kelio sukeliamus virpesius, yra vagonų vežimèliu pakaba. Jos parametrų parinkimui ir skiriamas šis poskyris.

Efektyvi (veiksni) geležinkelio riedmenų pakaba gerina komfortą ne tik keleiviniuose traukiniuose, bet ir didina važiuoklių, visų riedmenų elementų patikimumą ir ilgaamžiškuma, pozityviai veikia geležinkelių saugumą. Sudarant skaičiavimo modelius, pakabų efektyvumas išreiškiamas ivvairiomis tampriujų ir klampiujų elementų kombinacijomis, ivvertinamas dinaminiais klampos koeficientais ir kitais parametrais. Sprendžiant optimalių pakabos parametrų reikšmių nustatymo uždavinius, pirmiausia būtina išsiaiškinti klausimus, susijusius su šių 
uždaviniu sprendimo technologija. Norint gauti realius rezultatus, būtina nustatyti tikslo funkcijos komponentus, išaiškinti, ar būtina suteikti vieniems ar kitiems iš jų pirmenybę, ar visi komponentai privalo daryti vienodą itaką formuojant tikslo funkciją. Be to, būtina nustatyti skaičiavimo sąlygas, t. y. parinkti žadinimo (nelygumų) funkcijas ir važiuoklių riedejjimo sąlygas.

Jeigu dèl išvardytų veiksnių galima a priori parinkti tam tikras prielaidas, kurios gali būti tikslinamos skaičiuojant, tai parinkti riedmenu judesio greitị ir pradines reikšmes optimizuojant pakabų parametrus iš anksto nèra galimybių.

Keliamas uždavinys nustatyti tikslo funkcijos komponentus, svertines jų reikšmes, parinkti parametrų režimus, kuriems esant bus atliekami skaičiavimai, optimizuojamujų parametrų dydžių ribas, jų pradines reikšmes ir greičius.

\subsubsection{Tikslo funkcijos komponentai}

I tikslo funkciją būtina įtraukti ašidèžių ir centrinès pakabos pakopų normuojamus dinaminius rodiklius (Lingaitis, Dailydka, Myamlin, Prichodko 2008):

$K_{d v a}^{\max }$ - ašidèžès pakabos vertikalus dinaminis koeficientas;

$K_{d h a}^{\max }$ - ašidèžès pakabos horizontalus dinaminis koeficientas;

$K_{s}^{\min }$ - stovumo koeficientas, ivertinantis rato briaunos pasipriešinimą užlipimui ant bègio;

$K_{d v c}^{\max }$ - centrinès pakabos vertikalus dinaminis koeficientas;

$A_{\kappa v}^{\max }, g$ - vertikalus kèbulo pagreitis;

$A_{k h}^{\max }, g$ - horizontalus kèbulo pagreitis.

Šie dinaminiai rodikliai turi skirtingas leistinas ribines reikšmes. Jos parodytos 4.3 lentelèje.

4.3 lentelè. Pagrindinių dinaminių rodiklių leistinos reikšmès

Table 4.3. Limitary values of the main dynamic indicators

\begin{tabular}{|c|c|c|c|c|c|}
\hline$K_{d v a}^{\max }$ & $K_{d h a}^{\max }$ & $K_{s}^{\min }$ & $K_{d v c}^{\max }$ & $A_{k v}^{\max }, g$ & $A_{k h}^{\max }, g$ \\
\hline 0,8 & 0,38 & $1^{*}$ & 0,6 & 0,6 & 0,25 \\
\hline
\end{tabular}

* Skaičiuojant pagal bègio ir aširačio sąveikos jègas.

Ribojamos visų dinaminių rodiklių viršutinès reikšmės, išskyrus stovumo koeficiento reikšmę $K_{s}^{\min }$. Šiam rodikliui parenkama minimali leistinoji reikšmè. Siekiant suvesti dinaminių rodiklių kitimą (kaita) i vieną diapazoną nuo 0 iki 1 , juos būtina normuoti. Tam tikslui visus dinaminius rodiklius, išskyrus $K_{s}$, būtina padidinti iki jų maksimalių leistinujų reikšmių, o $K_{s}$ reikšmę pakeisti taip, kad normuotas rodiklis mažètų didinant $K_{s}$ ir didètų ją mažinant. İvertinus 
išdèstytus pakeitimus (perdirbimus), tikslo funkcijos parametrų vektorius atrodys taip (Lingaitis, Dailydka, Myamlin, Prichodko 2008):

$$
\bar{\varphi}=\left[\frac{K_{d v a}}{K_{d v a}^{\max }} \cdot \frac{K_{d h a}}{K_{d h a}^{\max }} \cdot \frac{\left(K_{s}^{\max }-K_{s}\right)}{K_{s}^{\max }-K_{s}^{\min }} \cdot \frac{K_{d v c}}{K_{d v c}^{\max }} \cdot \frac{A_{k v}}{A_{k v}^{\max }} \cdot \frac{A_{k h}}{A_{k h}^{\max }}\right]^{T} .
$$

čia $\mathrm{T}$ - transponuota matrica.

Tikslo funkcijos komponentų svertiniai koeficientai. Akivaizdu, kad dinaminių rodiklių įtaka yra skirtinga. Būtina turèti galimybę keisti vieno ar kito tikslo funkcijos komponento reikšmę. Tam tikslui kiekvienas tikslo funkcijos komponentas privalo turèti svertini (svarbos) koeficienta, kuris duos galimybę sustiprinti vienų tikslo funkcijos komponentų itaką jos reikšmei ir susilpninti kitų. Kad tikslo funkcijos reikšmé taip pat svyruotų diapazone nuo 0 iki 1, svertinių (svarbos) koeficientų suma turi būti lygi vienetui. Galutinai tikslo funkcija atrodys taip:

$$
F(\bar{\varphi})=\sum_{i=1}^{i=6} \lambda_{i} \varphi_{i}
$$

Skaičiuojant dinaminius vagono rodiklius didinant važiavimo greiti, visi jie artejja prie leistinų ribų. Patirtis rodo, kad pirmasis iš visų dinaminių rodiklių leistinas ribas viršija stovumo (rato briaunos pasipriešinimas užlipimui ant bégio) koeficientas, todèl visų svertinių koeficientų reikšmès $\lambda_{i}$, išskyrus koeficientą $K_{s}$, parinktos 0,1 , o $K_{s}$ atitinka 0,5 .

Norint atlikti skaičiavimus, reikia parinkti (nustatyti) žadinimo funkciją $\mathrm{i}$ važiuoklę. Tokiems žadinimams yra geometriniai bėgių kelio nelygumai vertikalioje ir skersinejje judesiui plokštumose. Nelygumai turi būti tokie, kad važiuoklę veiktų sužadinimo jègos visomis kryptimis ir pagal galimybę veiktų visų rūšių virpesiai. Skaičiuoti parenkami nesimetriniai atsitiktinio pobūdžio procesai papildyti nesimetrinèmis sandūromis vertikaliojoje plokštumoje, sukeliantys šoninius svyravimus. Skaičiavimams tikslinga pasirinkti tiesini ruoža, nes kreivèse važiavimo greitis ribojamas ne tik dinaminių rodiklių reikšmėmis, bet ir nenuslopintais pagreičiais, o tai apsunkintų parametrų parinkimą.

Daugelis mokslininkų, modeliuodami geležinkelio riedmenų važiuoklių judesi bėgiais, naudojasi geometrinèmis ir mechaninèmis kontaktuojančių kūnų savybèmis, taip pat taiko ìvairias teorijas praslystančių kūnų ten veikiančioms jègoms nustatyti (Лазарян, Длугач, Коротенко 1972; Данович 1981; Вериго, Коган 1986; Мямлин 2002a). Tačiau dažniausiai nagrinejjami rato ir bėgio sąveikos modeliai teigiant, kad ratas rieda nepertraukiamai, ivertinant arba neivertinant kelio nelygumus. Siekdami supaprastinti matematinius modelius autoriai 
parenka plokštumines skaičiavimo schemas, t. y. vertikaliojoje arba horizontaliojoje plokštumose. Tačiau norint tiksliau nustatyti svyravimo parametrus, tikslinga nagrinèti erdvinę modelio schemą. Nemažai autorių nagrinèjo ir nemažai matematinių erdvinių svyravimų modelių (Лазарян, Длугач, Коротенко 1972; Данович 1981; Мямлин 2002a), tačiau tik kai kuriuose (Мямлин 2003a) buvo bandyta matematiškai aprašyti rato nuo bėgio atotrūkio procesą.

Korektiškas rato ir bejgio sąveikos matematinis aprašymas, nustatant priverstinius važiuoklès virpesius, padès tiksliau apskaičiuoti dinaminius rodiklius ir ypač tuos, kurie turi didelę įtaką eismo saugumui. Toks matematinis modelis išsamiai išnagrinètas darbe (Dailydka, Lingaitis, Myamlin, Prichodko 2008a).

Toliau nagrinejjamas rato ir bėgio sąveikos matematinis modelis, ivvertinant rato atotrūkį nuo bègio, kai ratas praranda kontaktą su bègiu.

Tarkime, ratą veikia jèga $Q$. Tuomet $y$ bus bègio įlinkis, o $R(y)-$ bègio reakcija įlinkiui. Kai tarp rato ir bėgio yra kontaktas, galima parašyti diferencialinę lygtị:

$$
m \frac{d^{2} y}{d t^{2}}=-R(y)+Q
$$

čia $m$ - rato masè.

Ši lygybė yra nagrinèjama darbe (Блохин, Данович, Морозов 1986). Ја remiantis buvo gauti itempiai tiesiniame bėgyje ir bègyje su nelygumais $\eta(x)$, kai ratas riedejo pastoviu greičiu $v$.

Vietoje lygties (4.10) nagrinejjam tokio tipo lygtis:

$$
m \frac{d^{2} y}{d t^{2}}=-R(y) \cdot H(y)+Q
$$

čia $H(y)$ - Chevisaido funkcija, t. y.:

$$
H(y)= \begin{cases}0, & \text { kai } y \leq 0 \\ 1, & \text { kai } y>0 .\end{cases}
$$

Tuo atveju, kai yra nelygumų ant bejgio, pasirinkus pagal $x$ atskaitos tašką pradžioje nelygumo diferencialinę lygti galima užrašyti taip:

$$
m \frac{d^{2} y}{d t^{2}}=-R(y) \cdot H(y)+Q-m \frac{d^{2} \eta(v \cdot t)}{d t^{2}},
$$

kuri teisinga esant $t \subset[0, \ell / v]$, čia $\ell$ - nelygumo ilgis. 
Toliau teigiama, kad bėgio reakcija i illinki $y$ atitinka tampriai plastiško kūno reakciją ir gali būti išreikšta taip:

$$
R(y)=\beta \frac{d y}{d t}+k y .
$$

čia $\beta$-slopinimo koeficientas.

Ivertinant tiksliau, ši reakcija priklauso ir nuo vietos, kurioje ratas kontaktuoja su bėgiu (tarp pabėgiu ar ties pabėgiu), tuomet vietoje (4.13) naudojama išraiška:

$$
R(y, x)=\left(\beta \frac{d y}{d t}+k y\right) \cdot \varphi(x),
$$

čia $\varphi(x)$ - periodinè funkcija, kurios periodas lygus atstumui tarp pabėgių.

Siekiant sudaryti rato ir bėgio saveikos matematini modeli, labiau atitinkantị realias sąlygas, toliau nagrinėjama skaičiavimo schema, pavaizduota 4.6 pav.

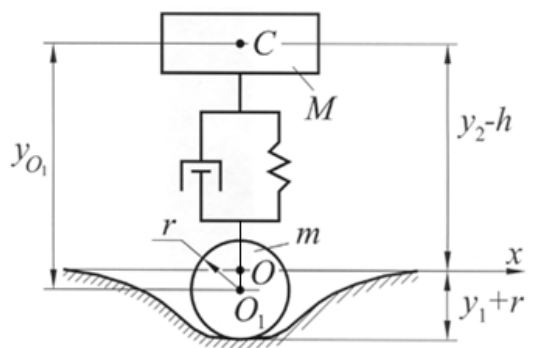

4.6 pav. Rato ir bėgio kontakto skaičiavimo schema su tamprioji pakaba

Fig. 4.6. Wheel-rail contact calculation scheme with an elastic suspension

$y_{1}$, kaip ir anksčiau, žymimas bejgio illinkis sąlyčio su ratu vietoje, o $y_{2}-h-$ kūno $C$ masès centro koordinatè, tuomet teigiant, kad:

$$
y=\frac{m\left(y_{1}+r\right)+M\left(y_{2}-h\right)}{m+M},
$$

sudaroma tokia diferencialinių lygčių sistema:

$$
\begin{gathered}
m \frac{d^{2} y_{1}}{d t^{2}}=-R\left(y_{1}, x\right) \cdot H\left(y_{1}\right)+R_{1}\left(y_{2}\right)+m g, \\
(m+M) \frac{d^{2} y}{d t^{2}}=-R\left(y_{1}, x\right) \cdot H\left(y_{1}\right)+(m+M) g,
\end{gathered}
$$


čia: $M$ - kūno $C$ masé; $r$ - rato spindulys; $R_{1}\left(y_{2}\right)$ - tampriosios pakabos reakcija, kurią galima išreikšti taip:

$$
R_{1}\left(y_{2}\right)=\beta_{1} \frac{d y_{2}}{d t}+k_{1} y_{2} .
$$

Iš (4.15) randama $y_{2}$ :

$$
y_{2}=\frac{y-\alpha\left(y_{1}+r\right)+\beta h}{\beta},
$$

čia $\alpha=m /(M+m) ; \beta=M /(M+m)$.

Dabar istačius $y_{2}$ i (4.16) ir (4.17) lygtis, gaunama tokia diferencialiniu lygčių sistema:

$$
\left\{\begin{array}{l}
m \frac{d^{2} y_{1}}{d t^{2}}=-R\left(y_{1}, x\right) H\left(y_{1}\right)+R_{1}\left(y_{1}-r-h-\frac{y-\alpha\left(y_{1}+r\right)}{\beta}\right)+m g ; \\
(m+M) \frac{d^{2} y}{d t^{2}}=-R\left(y_{1}, x\right) H\left(y_{1}\right)+(m+M) g,
\end{array}\right.
$$

kuri aprašo rato ir bėgio sąveiką, kai nèra nelygumų nei ant bėgio, nei ant rato riedejjimo paviršiaus.

(4.10) lygtis užrašoma pavidalu:

$$
\frac{d^{2} z}{d t^{2}}+2 n \frac{d z}{d t}+p_{2} \cdot z=g
$$

čia: $z$ - transformuotas vertikalusis poslinkis; $n$ - slopinimo koeficientas; $p_{2}-$ standumo koeficientas.

Bendrasis sprendinys analitine forma gaunamas toks:

$$
\begin{aligned}
& z(t)=\frac{1}{2} \frac{e^{\left(\left(-n+\sqrt{n^{2}-p_{2}}\right) t\right)}\left(-n g+n p_{2}-\sqrt{n^{2}-p_{2}} g+\sqrt{n^{2}-p_{2}} p_{2}\right)}{\sqrt{n^{2}-p_{2}} p_{2}}+ \\
& \frac{\frac{1}{2} e^{\left(\left(-n-\sqrt{n^{2}-p_{2}}\right) t\right)}\left(n g-n p_{2}-\sqrt{n^{2}-p_{2}} g+\sqrt{n^{2}-p_{2}} p_{2}\right)}{\sqrt{n^{2}-p_{2}} p_{2}}+\frac{g}{p_{2}} .
\end{aligned}
$$

Teigiant, $\operatorname{kad} n=5, p_{2}=500, g=9,8$, šis sprendinys igaus tokią formą: 


$$
\begin{aligned}
& z(t)=-\frac{1}{475000} e^{((-5+\sqrt{-475}) t)}(2451,0+490,2 \sqrt{-475}) \sqrt{-475}- \\
& \frac{1}{475000} e^{((-5-\sqrt{-475}) t)}(-2451,0+490,2 \sqrt{-475}) \sqrt{-475}+0,0196 .
\end{aligned}
$$

Šio sprendinio grafinè interpretacija pateikta 4.7 pav.

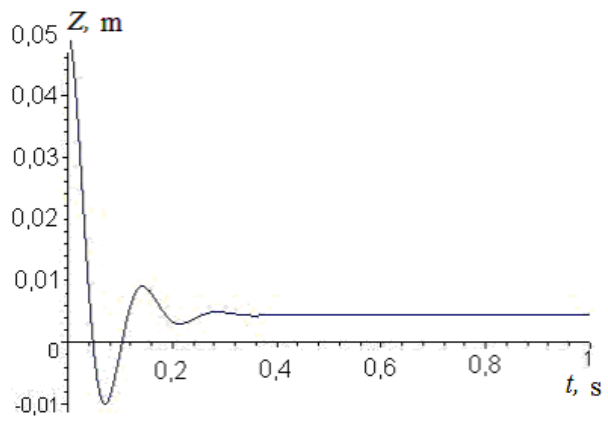

4.7 pav. (4.10) lygties sprendimo grafikas

Fig. 4.7. The decision graph of equation (4.10)

Tokie skaičiavimai atlikti esant sužadinimo funkcijoms su skirtingomis pradinèmis sąlygomis:

$$
y\left(t_{0}\right)=0 \text { ir } y^{\prime}\left(t_{0}\right)=z^{\prime}\left(t_{0}\right),
$$

čia $t_{0}$ - minimalus laikas, kai $y(t)$ lygi 0 .

Išsamesnè analizė atlikta Dailydkos, Lingaičio, Myamlin, Prichodko darbe (2008a).

Naudodami diferencialinių lygčių sprendimo metodų sprendinius (analogiškus 4.7 pav.), kurie rodo, kad skaičiuojant dinaminius procesus, vykstančius geležinkelio riedmenyse, būtina vertinti kontaktą tarp rato ir bejgio kaip nestabilų darantị labai didelę įtaką eksploataciniams parametrams. Kuo didesnis greitis, tuo ši itaka didesnè. Tai labai svarbu parenkant važiuokles šiu dienu riedmenims, kai didejant greičiams keliami vis aukštesni reikalavimai keleiviu komfortui.

Pagrindinis reikalavimas parenkant vienus ar kitus spyruoklių komplektų standumo dydžius turi būti galimybè realizuoti šiuos pakabos parametrus. Be to, vertikalūs pakabos standumai papildomai ribojami gretimų važiuoklių automatinių sankabų leidžiamu aukščių skirtumu. 
Šie ribojimai bus akivaizdūs galutinai parenkant pakabos parametrų reikšmes. Kol kas nustatyti sąlygoms, kuriomis reikia atlikti optimizavimo skaičiavimus, parenkamas gana platus parametrų diapazonas:

1. Standumo (K), kurio diapazonas $0-60000 \mathrm{kN} / \mathrm{m}$.

2. Klampumo (V), kurio diapazonas $0-100 \mathrm{kNs} / \mathrm{m}$.

3. Trinties koeficientai (F), kurių diapazonas $0,01-0,25$.

Tikslo funkcija, aprašoma (4.8) išraiška, priklauso nuo daugelio parametrų, todèl reikia tikètis, kad šia funkcija aprašomas paviršius bus gana sudètingos formos. Bendru atveju šis paviršius turès daugybę lokalinių minimumų. Reiškia, norint nustatyti optimalius parametrus, reikia pirmiau surasti sritis, kuriose išdèstyti lokaliniai minimumai. Jeigu tokia sritis turi ne vieną lokalini minimumą tai optimalių parametrų paieškos rezultatas priklausys nuo pradinių reikšmių. Šiame etape judesio greičiams nustatyti, kuriems esant reikètų ieškoti optimalių važiuoklès pakabos pakopų parametru, imamos vežimèlio CNII-Ch3 parametrų standartinès reikšmès (4.4 lentelè).

4.4 lentelè. Vežimèlio CNII-Ch3 važiuoklès parametrai

Table 4.4. Carriage CNII-Ch 3 chassis parameters

\begin{tabular}{|c|c|c|c|}
\hline $\begin{array}{l}\text { Važiuoklès } \\
\text { parametrai }\end{array}$ & Išilginė kryptis & Skersinè kryptis & Vertikalioji krytis \\
\hline Ašidéžių pakaba & $\begin{array}{l}K_{a x}=0 \mathrm{kN} / \mathrm{m} \\
F_{a x}=0,25\end{array}$ & $\begin{array}{l}K_{a y}=0 \quad \mathrm{kN} / \mathrm{m} \\
F_{a y}=0,25\end{array}$ & $\begin{array}{l}K_{a z}=20000 \mathrm{kN} / \mathrm{m} \\
V_{a z}=100 \mathrm{kNs} / \mathrm{m}\end{array}$ \\
\hline Centrinè pakaba & $\begin{array}{l}K_{c x}=6000 \mathrm{kN} / \mathrm{m} \\
F_{c x}=0,25\end{array}$ & $\begin{array}{l}K_{c y}=6000 \mathrm{kN} / \mathrm{m} \\
F_{c y}=0,1\end{array}$ & $\begin{array}{l}K_{c z}=4000 \mathrm{kN} / \mathrm{m} \\
F_{c z}=0,1\end{array}$ \\
\hline Šliaužikliai & $\begin{array}{l}K_{\check{s x}}=0 \mathrm{kN} / \mathrm{m} \\
F_{\check{s} x}=0,125\end{array}$ & $\begin{array}{l}K_{\check{s y}}=0 \mathrm{kN} / \mathrm{m} \\
F_{\check{s y}}=0,125\end{array}$ & $\begin{aligned} K_{s z} & =800 \mathrm{kN} / \mathrm{m} \\
V_{s z} & =0 \mathrm{kNs} / \mathrm{m}\end{aligned}$ \\
\hline
\end{tabular}

\subsubsection{Judesio greičio parinkimas}

Pradžioje reikia atsakyti i klausimą apie greičio parinkimą skaičiavimams, sprendžiant optimalių važiuoklès parametrų paieškos uždavinius. Tam atliekama optimaliu parametrų paieška esant skirtingiems važiavimo greičiams, kai pradiniai parametrai tokie patys, kurie pasirinkti pirmiau. Apskaičiuojami optimalūs parametrai, kai važiavimo greitis $v=60 \mathrm{~km} / \mathrm{h}$.

Optimalių parametrų paieškos rezultatai pateikti 4.5 lentelèje.

Ašidėžių pakabos optimalios parametrų reikšmès skirtingomis kryptimis:

- išilgine kryptimi $K_{a x}=0, F_{a x}=0,25$;

- skersine kryptimi $K_{a y}=0, F_{a y}=0,19$;

- vertikaliaja kryptimi $K_{a z}=15530, V_{a z}=100$. 
4.5 lentelè. Pagrindiniai dinaminiai rodikliai

Table 4.5. The main dynamic indicators

\begin{tabular}{|l|c|c|c|c|c|}
\cline { 2 - 6 } \multicolumn{1}{c|}{} & $K_{d v a}$ & $K_{d h a}$ & $K_{s}$ & $K_{a v c}$ & $\begin{array}{c}\text { Tikslo } \\
\text { funkcija }\end{array}$ \\
\hline $\begin{array}{l}\text { Esant pradinėms parametrų } \\
\text { reikšmėms }\end{array}$ & 0,327 & 0,218 & 2,399 & 0,33 & 0,27943 \\
\hline $\begin{array}{l}\text { Esant optimalioms } \\
\text { parametrų reikšmėms }\end{array}$ & 0,287 & 0,183 & 3,21 & 0,286 & 0,10732 \\
\hline Skirtumas, \% & -12 & -16 & 34 & -13 & -62 \\
\hline
\end{tabular}

Centrinès pakabos optimalios parametrų reikšmès skirtingomis kryptimis:

- išilgine kryptimi $K_{c x}=5750, F_{c x}=0,165$;

- skersine kryptimi $K_{c y}=10700, F_{c y}=0,016$;

- vertikaliaja kryptimi $K_{c z}=2620, F_{c z}=0,116$.

Šliaužiklių optimalios parametrų reikšmès skirtingomis kryptimis:

- išilgine kryptimi $K_{\check{s} x}=0, F_{\check{s} x}=0,12$;

- skersine kryptimi $K_{\check{s} y}=0, F_{\check{s} y}=0,105$;

- vertikaliaja kryptimi $K_{\check{s z}}=290, V_{\check{s} z}=0$.

Grafinis $K_{d}$ ir $K_{s}$ kitimas parodytas 4.8, 4.9 ir 4.10 pav.

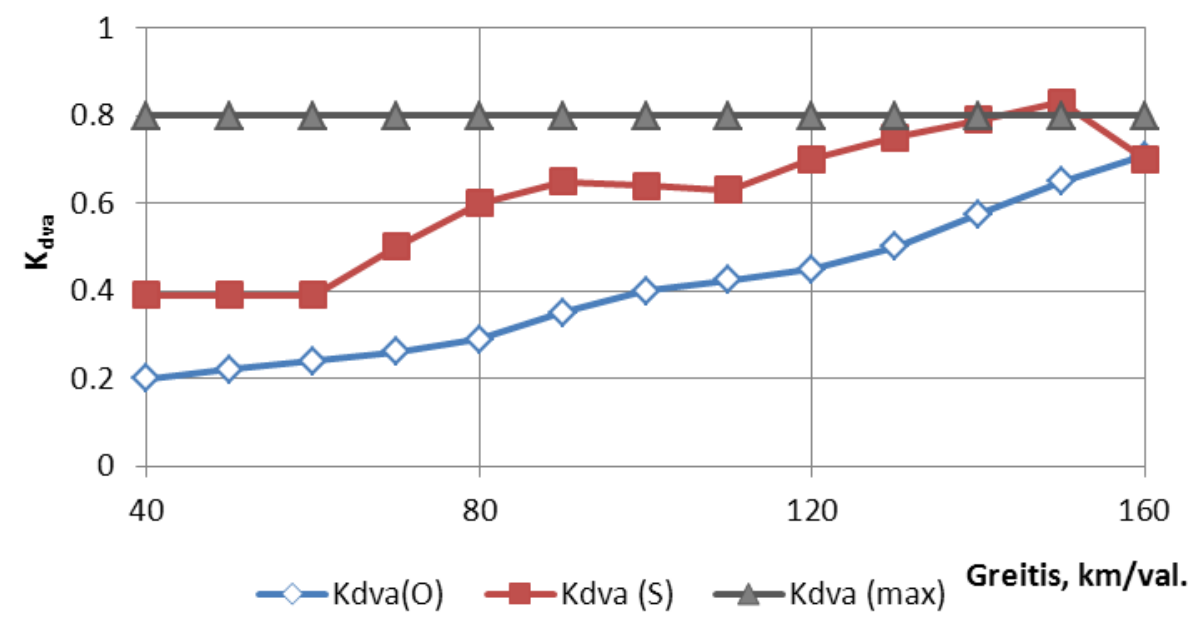

4.8 pav. Ašidèžès pakabos koeficientas $K_{d v a}$

Fig. 4.8. Axle-box suspension coefficient $K_{d v a}$ 


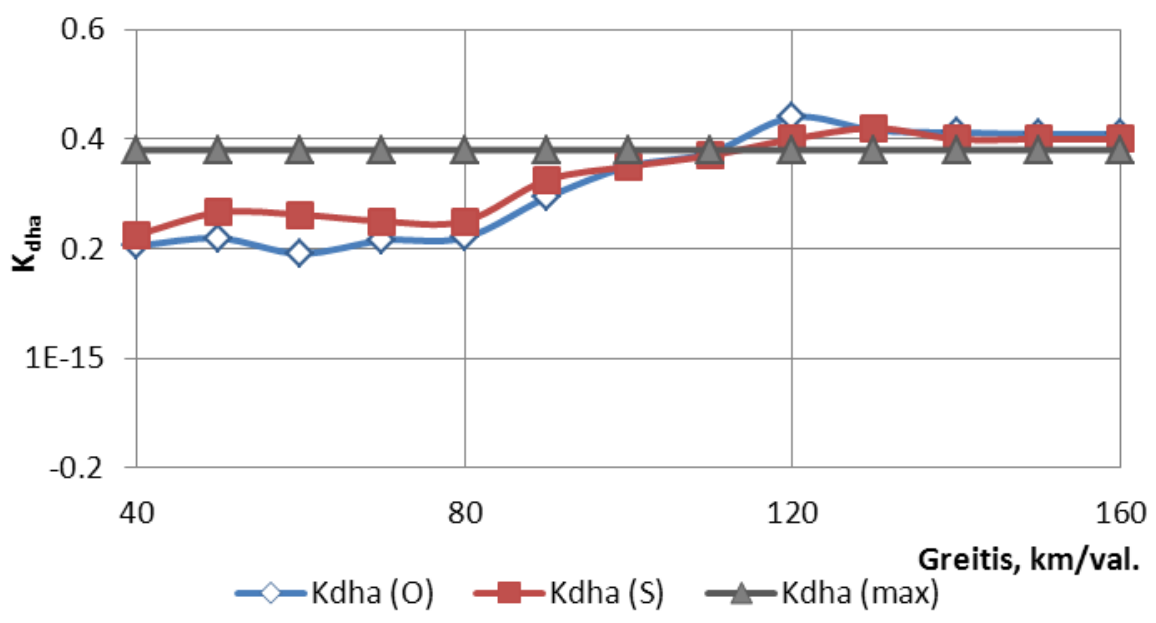

4.9 pav. Ašidèžès pakabos koeficientas $K_{d h a}$

Fig. 4.9. Axle-box suspension coefficient $K_{d h a}$

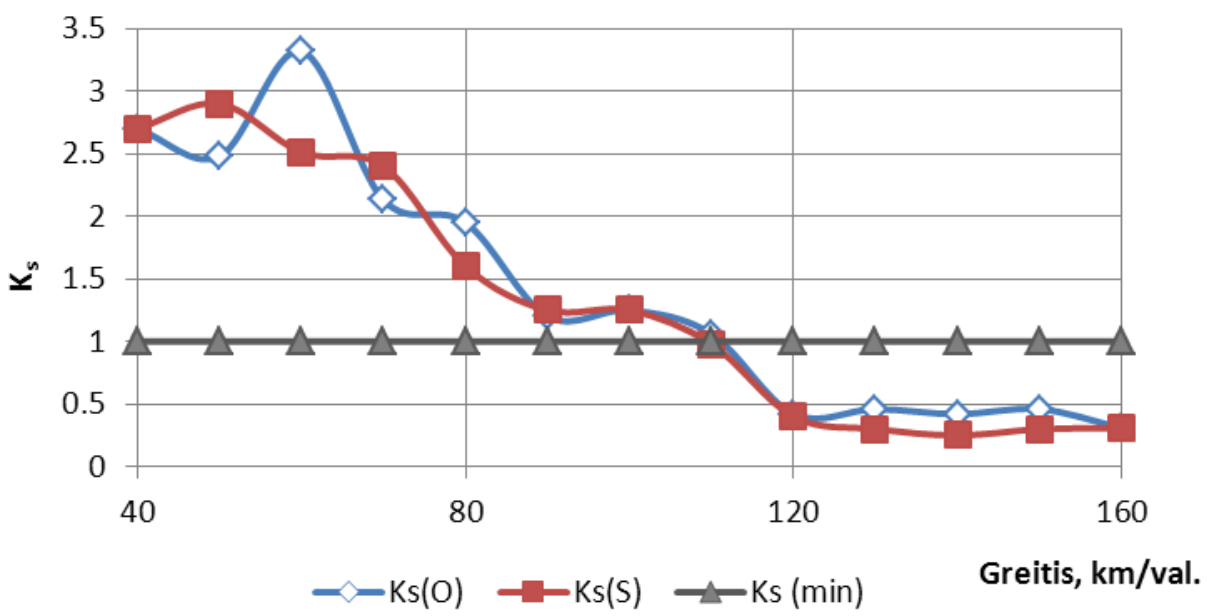

4.10 pav. Stovumo (pastovumo) koeficientas $K_{s}$

Fig. 4.10. Stability coefficient $K_{s}$

Iš 4.8-4.10 pav. pateiktų skaičiavimo rezultatų matyti, kad pasirinkto vežimélio tiek su standartiniais $(\mathrm{S})$, tiek su optimizuotais $(\mathrm{O})$ parametrais ribinis važiavimo greitis yra $100 \mathrm{~km} / \mathrm{h}$. Jị riboja koeficientas $K_{s}$. Toliau rodomi skaičiavimo rezultatai, kai greitis $v=140 \mathrm{~km} / \mathrm{h}$ (4.6 lentelè). 
4.6 lentelè. Pagrindiniai dinaminiai rodikliai

Table 4.6. The main dynamic characteristics

\begin{tabular}{|l|c|c|c|c|c|}
\cline { 2 - 6 } \multicolumn{1}{c|}{} & $K_{d v a}$ & $K_{d h a}$ & $K_{s}$ & $K_{a v c}$ & $\begin{array}{c}\text { Tikslo } \\
\text { funkcija }\end{array}$ \\
\hline $\begin{array}{l}\text { Esant pradinėms parametrų } \\
\text { reikšmėms }\end{array}$ & 0,548 & 0,254 & 1,213 & 0,536 & 0,897 \\
\hline $\begin{array}{l}\text { Esant optimalioms parametru } \\
\text { reikšmèms }\end{array}$ & 0,349 & 0,223 & 2,289 & 0,373 & 0,418 \\
\hline Skirtumas, \% & -36 & -12 & 89 & -30 & -53 \\
\hline
\end{tabular}

Ašiděžių pakabos optimalios parametrų reikšmès skirtingomis kryptimis:

- išilgine kryptimi $K_{a x}=0, F_{a x}=0,23$;

- skersine kryptimi $K_{a y}=0, \quad F_{a y}=0,23$;

- vertikaliaja kryptimi $K_{a z}=18200, V_{a z}=93$.

Centrinès pakabos optimalios parametrų reikšmès skirtingomis kryptimis:

- išilgine kryptimi $K_{c x}=5470, F_{c x}=0,23$;

- skersine kryptimi $K_{c y}=5490, F_{c y}=0,09$;

- vertikaliaja kryptimi $K_{c z}=3490, \quad F_{c z}=0,09$.

Šliaužiklių optimalios parametrų reikšmès skirtingomis kryptimis:

- išilgine kryptimi $K_{\check{s} x}=0, F_{\check{s} x}=0,12$;

- skersine kryptimi $K_{\check{s} y}=0, F_{\check{s} y}=0,12$;

- vertikaliaja kryptimi $K_{\check{s z}}=748, V_{\check{s} z}=0$.

Grafinis $K_{d}$ ir $K_{s}$ kitimas parodytas $4.11,4.12$ ir 4.13 pav.

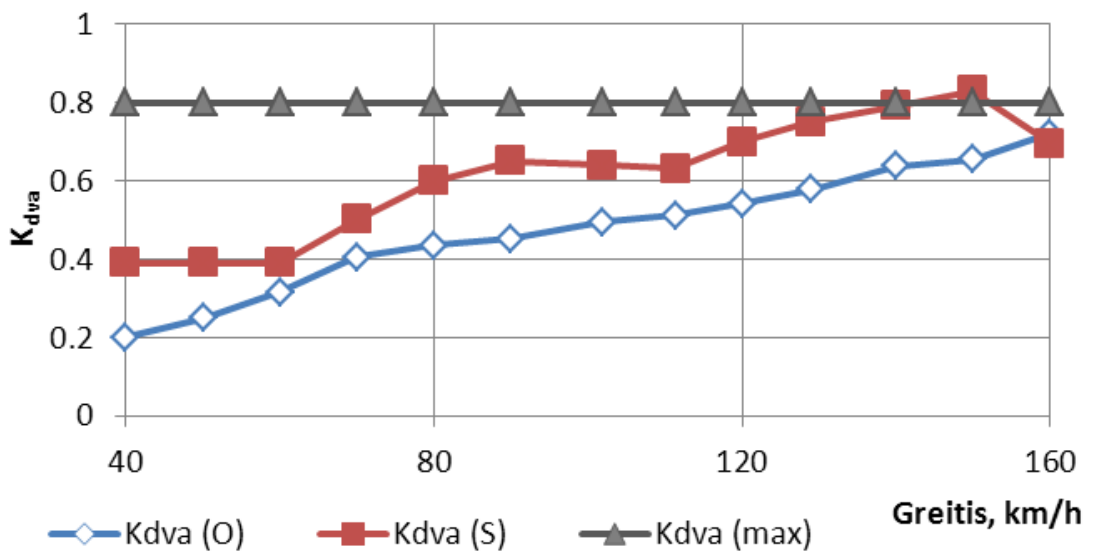

4.11 pav. Ašidèžès pakabos koeficientas $K_{d v a}$

Fig. 4.11. Axle-box suspension coefficient $K_{d v a}$ 


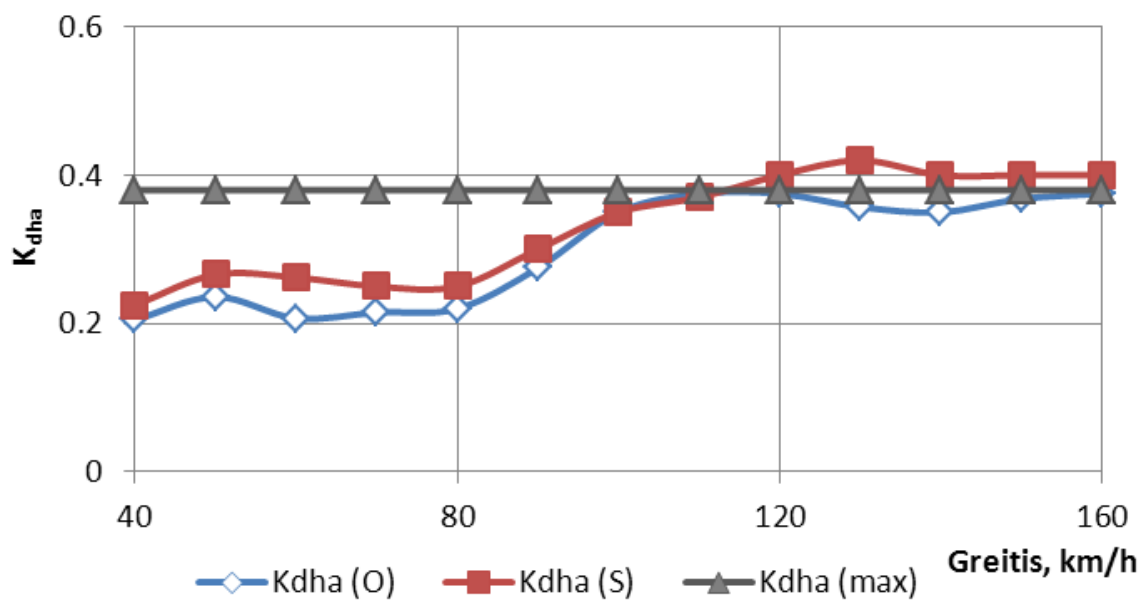

4.12 pav. Ašidèžès pakabos koeficientas $K_{d h a}$

Fig. 4.12. Axle-box suspension coefficient $K_{d h a}$

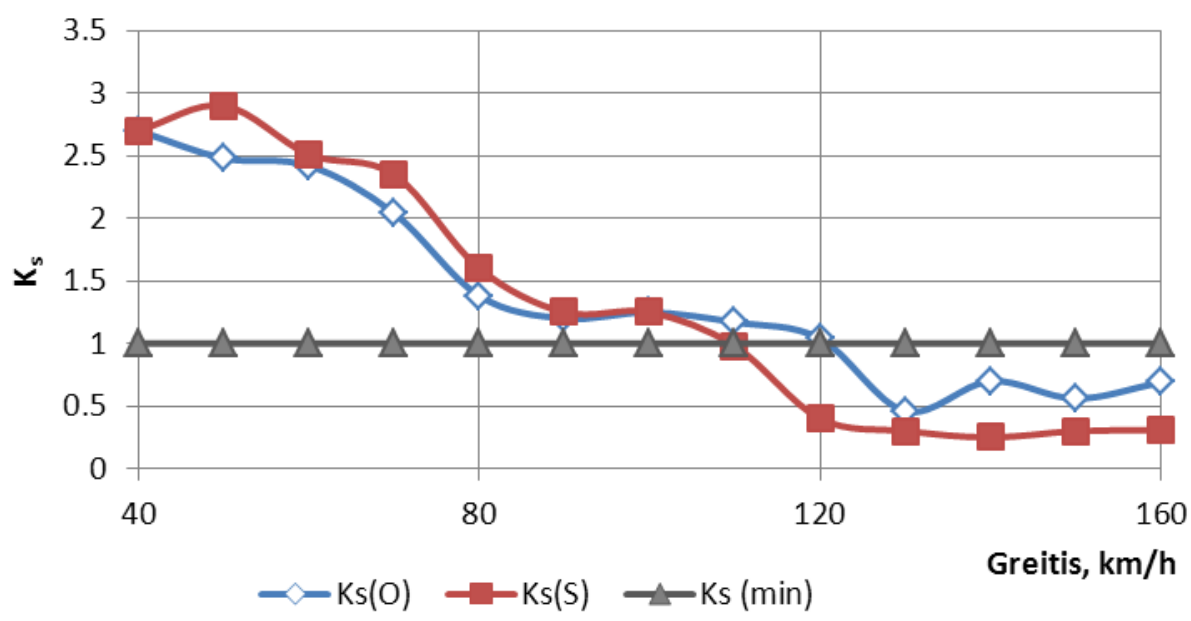

4.13 pav. Stovumo koeficientas $K_{s}$

Fig. 4.13. Stability coefficient $K_{s}$

Esant šiam greičiui nepasisekè pasiekti leistinujų $K_{d h a}$ ir $K_{s}$ reikšmių. Tokie skaičiavimai buvo atlikti esant $60,80,110,120$ ir $140 \mathrm{~km} / \mathrm{h}$ greičiams.

Išvada. Atliktų skaičiavimų rezultatų analizè parodè, kad nustatant optimalius važiuokliu pakabų parametrus, pagrindiniu rodikliu tikslo funkcijoje reikia 
laikyti stovumo koeficienta, nes šis parametras pirmasis riboja važiavimo greitị. Skaičiuoti reikètų imant mažiausią greiti, kuriam esant dinaminių rodiklių reikšmès viršija leistinąsias ribas. Toliau reikia ieškoti sprendinių su kitomis pradinių parametrų reikšmėmis, kiekvieną kartą nustatant minimalu greiti, kuriam esant dinaminių rodiklių reikšmès viršija leistinąsias ribas. Ši metodika labai svarbi skaičiuojant važiuoklès parametrus nuolat augant traukinių greičiams.

\subsubsection{Optimalių vežimèlio pakabos parametrų parinkimas}

Taigi, projektuojant naujus ir tobulinant esamus keleivinius vagonus, būtina iš anksto įvertinti dinamines jų savybes. Dinaminių apkrovų mažinimo keleiviniuose vagonuose lemiamas veiksnys, leidžiantis didinti ir greičius, yra racionalus pakabos pakopu parinkimas (Мямлин 2003b; Мямлин 2002a; Манашкин, Мямлин, Приходько 2007).

Viena iš pažangiausių pakabų (Мямлин 2003b; Манашкин, Мямлин, Приходько 2007), kuri intensyviausiai slopina virpesius, yra pneumatinè pakaba. Todèl bandoma nustatyti centrinès vežimèlio 68-7007 (4.14 pav.) pakabos parametrus siekiant tobulinti spyruoklių pakabos slopinimo savybes siekiant eksploatacinio greičio iki $300 \mathrm{~km} / \mathrm{h}$.

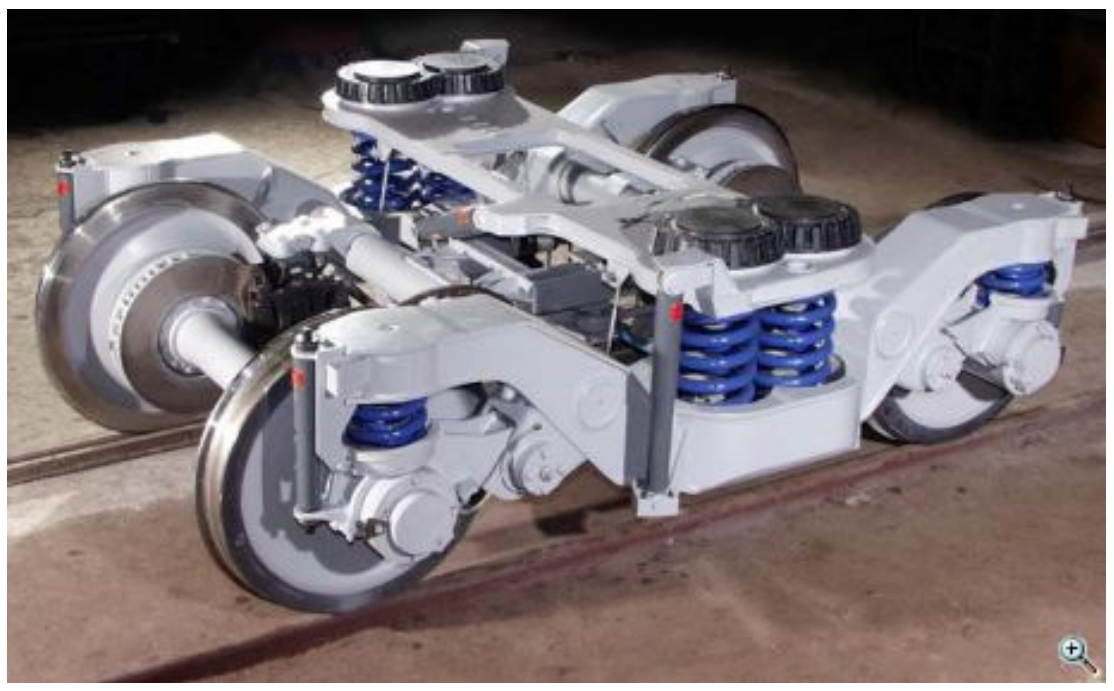

4.14 pav. 68-7007 modelio dviejų ašių vežimèlis

Fig. 4.14. Two-axle carriage 68-7007

Sudaryta ir išnagrinèta daug atskirų virpesių slopintuvų bei amortizatorių ir sudètingesnių bèginių vežimèlių konstrukcijų matematinių modelių (Мямлин 
2003b; Николаев 2003; Манашкин, Мямлин, Приходько 2007). Buvo bandymai patobulinti erdvinius keleivinių vagonų matematinius modelius (Мямлин, Приходько, Жижко 2007). Tačiau būtent pneumatinès pakabos optimalūs parametrai nebuvo nustatinejjami. İvertinus keleivinių vagonų tobulinimo tendencijas, pneumatinių pakabų parametrų nustatymas yra labai svarbus geležinkelių transportui.

Pradžioje būtina parinkti sužadinimus (nelygumus), veikiančius nuo kelio. Jie bus naudojami nustatant optimalius vežimèlio pneumatinių pakabų parametrus. Norint parinkti nelygumų lygti, reikia atlikti judesio modeliavimą tiesiniame kelyje. Nelygumų amplitude nustatoma tokia, kad dinaminiai rodikliai neviršytų leistinų ribų iki šiuo metu nustatyto maksimalaus keleivinių traukinių važiavimo greičio, t. y. $120 \mathrm{~km} / \mathrm{h}$.

Jeigu nagrinejjamas keleivinis vagonas su vežimèliu KVZ-CNII (4.15 pav.), jis atitiks eksploatacijos sąlygas. Nors sužadinimų intensyvumas bus šiek tiek padidintas, tačiau tai gali būti priskiriama eismo saugumo atsargai.

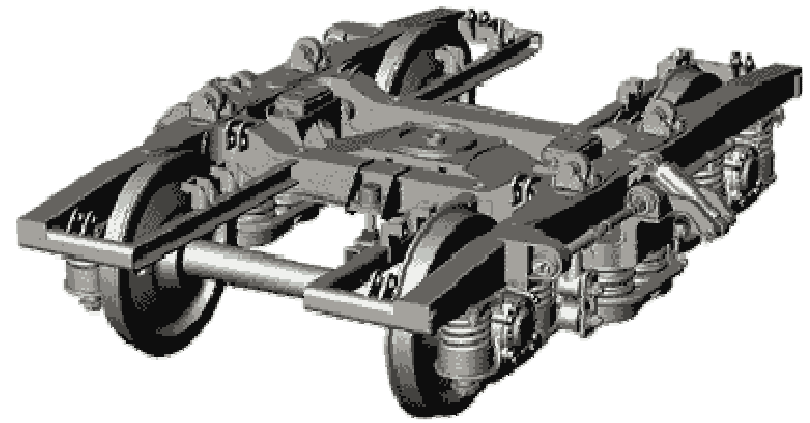

4.15 pav. KVZ-CNII modelio keleivinio vagono vežimèlis

Fig. 4.15. Carriage KVZ-CNII

Keleivinių vagonų dinaminių rodiklių leistinosios reikšmès pateiktos 4.7 lentelèje. Kelio nelygumų oscilogramos tiesiniame ruože pateiktos 4.16 pav.

4.7 lentelè. Keleivinių vagonų dinaminių rodiklių leistinosios reikšmès

Table 4.7. Carriages allowed values of dynamic parameters

\begin{tabular}{|l|c|}
\hline \multicolumn{1}{|c|}{ Rodiklis } & Dydis \\
\hline Kėbulo rėmo vertikaliosios dinamikos koeficientas $K_{d v c}$ & 0,20 \\
\hline Vežimėlio rėmo vertikaliosios dinamikos koeficientas $K_{d v a}$ & 0,35 \\
\hline Vežimėlio rèmo horizontaliosios dinamikos koeficientas $K_{d h}$ & 0,24 \\
\hline $\begin{array}{l}\text { Tolygios eigos rodikliai vertikaliojoje } W_{v} \text { ir horizontaliojoje } W_{h} \text { plokštu- } \\
\text { mose }\end{array}$ & 3,25 \\
\hline $\begin{array}{l}\text { Stovumo koeficiento } K_{s} \text { vagono nusidėvėjimui nuo bègių atsarga, kai } \\
\text { tikimybė } 0,001\end{array}$ & 1,80 \\
\hline
\end{tabular}



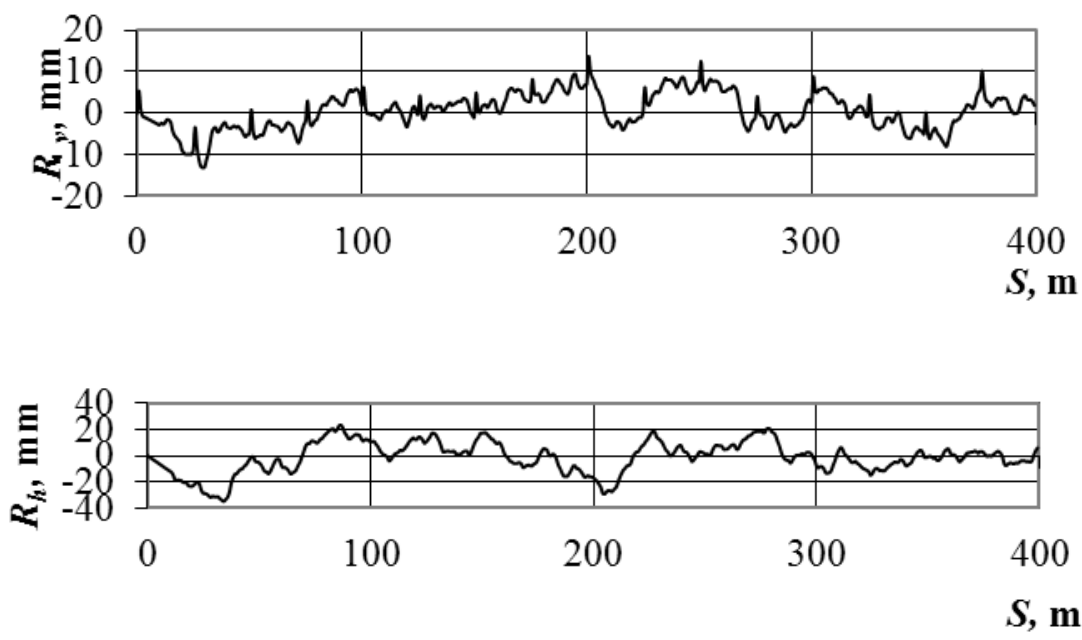

4.16 pav. Kelio nelygumai vertikalioje ir horizontalioje plokštumose

Fig. 4.16. The road roughness in vertical and horizontal planes

Keleivinių vagonų dinaminiai rodikliai $K_{d v a}, K_{d h a}$ ir $K_{s}$ pateikti 4.17 pav.

Keleivinių vagonų dinaminiai rodikliai $K_{d v c}, W_{v}$ ir $W_{h}$ pateikti 4.18 pav.

Kaip matyti iš grafikų, visi vagonų su vežimèliais KVZ-CNII dinaminiai rodikliai neviršija leistinujų ribų esant greičiams iki $120 \mathrm{~km} / \mathrm{h}$ imtinai. Toliau didinant greiti, $K_{d v a}$ ir $K_{d h a}$ viršija leistinąsias reikšmes.

Vagonu 61-779 (4.19 pav.) ir 61-788 (4.20 pav.) modeliu su vežimèliu 687007 dinaminių rodiklių reikšmès praktiškai vienodos visame nagrinètame greičių diapazone.

61-779 ir 61-788 modelių vagonų vertikalios dinamikos rodikliai $K_{d v a}, K_{d v c}$ ir $W_{v}$ daug mažesni už leistinąsias reikšmes esant greičiams iki $300 \mathrm{~km} / \mathrm{h}$.

Vertinant horizontalią dinamika, tai $K_{d h a}$ reikšmé viršija leistinają esant $220 \mathrm{~km} / \mathrm{h}$ greičiui. Kadangi šis rodiklis yra pirmosios pakabos pakopos (ašidèžès), tai prieš pereinant prie antrosios pakabos pakopos (centrinès pneumatinès pakabos) reikia $K_{d h a}$ sumažinti iki leistinosios reikšmès. 

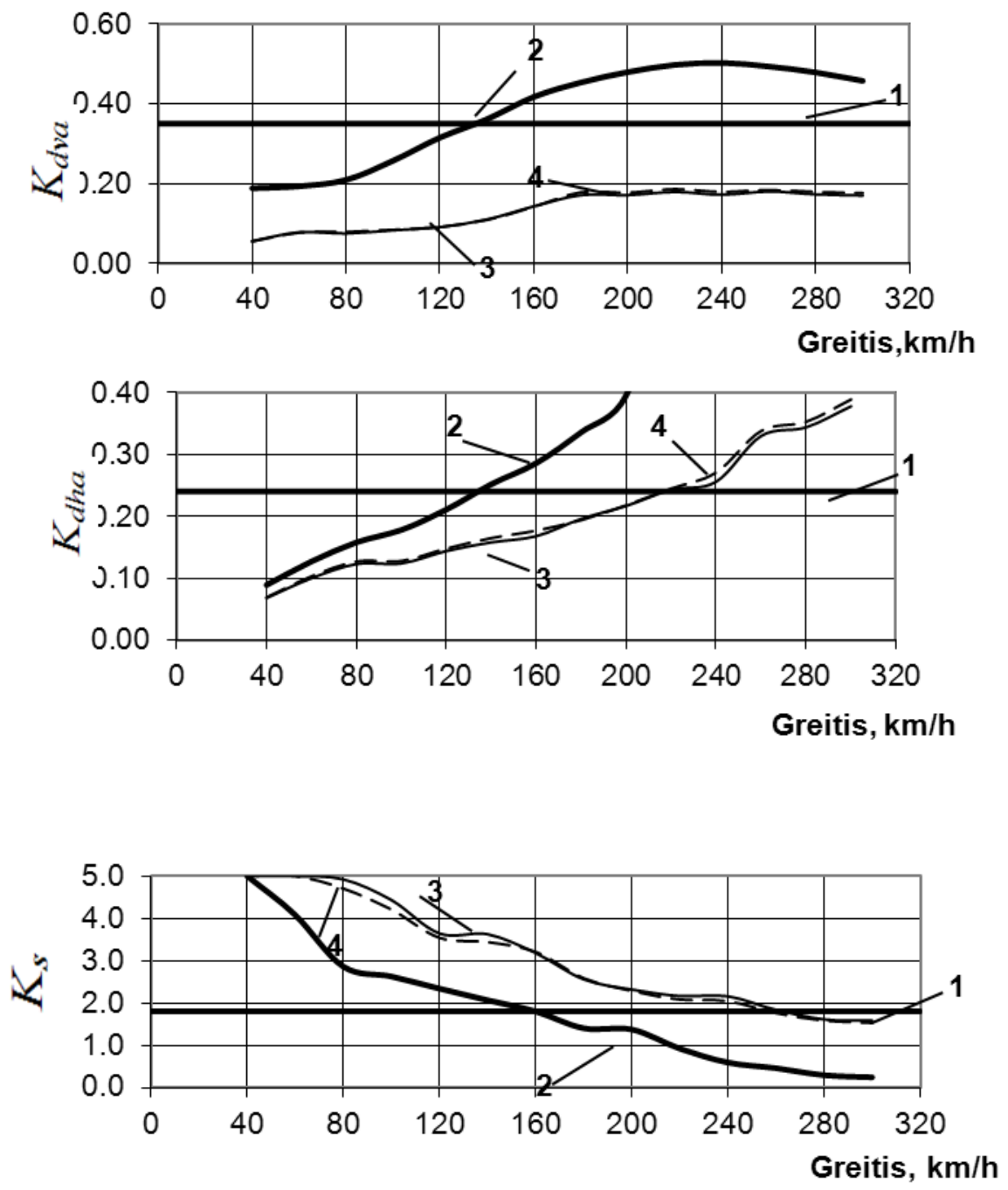

4.17 pav. Keleivinių vagonų dinaminiai rodikliai $K_{d v a}, K_{d h a}$ ir $K_{s}$ :

1 - dinaminių rodiklių leistinieji dydžiai; 2 - keleivinių vagonų su KVZ-CNII vežimèliais dinaminių rodiklių reikšmès; 3 - keleivinių vagonų 61-779 modelio su 68-7007 vežimèliais dinaminių rodiklių reikšmès; 4 - keleivinių vagonų 61-788 modelio su 687007 vežimèliais dinaminių rodiklių reikšmès

Fig. 4.17. Carriages dynamic characteristics $K_{d v a}, K_{d h a}$ and $K_{s}$ :

1 - dynamic variables within limits; 2 - dynamic indicators to the carriages with KVZCNII carriages, 3 - dynamic indicators to the carriages 61-779 with 68-7007 carriages, 4 -dynamic indicators to the carriages $61-788$ with 68-7007 carriages 

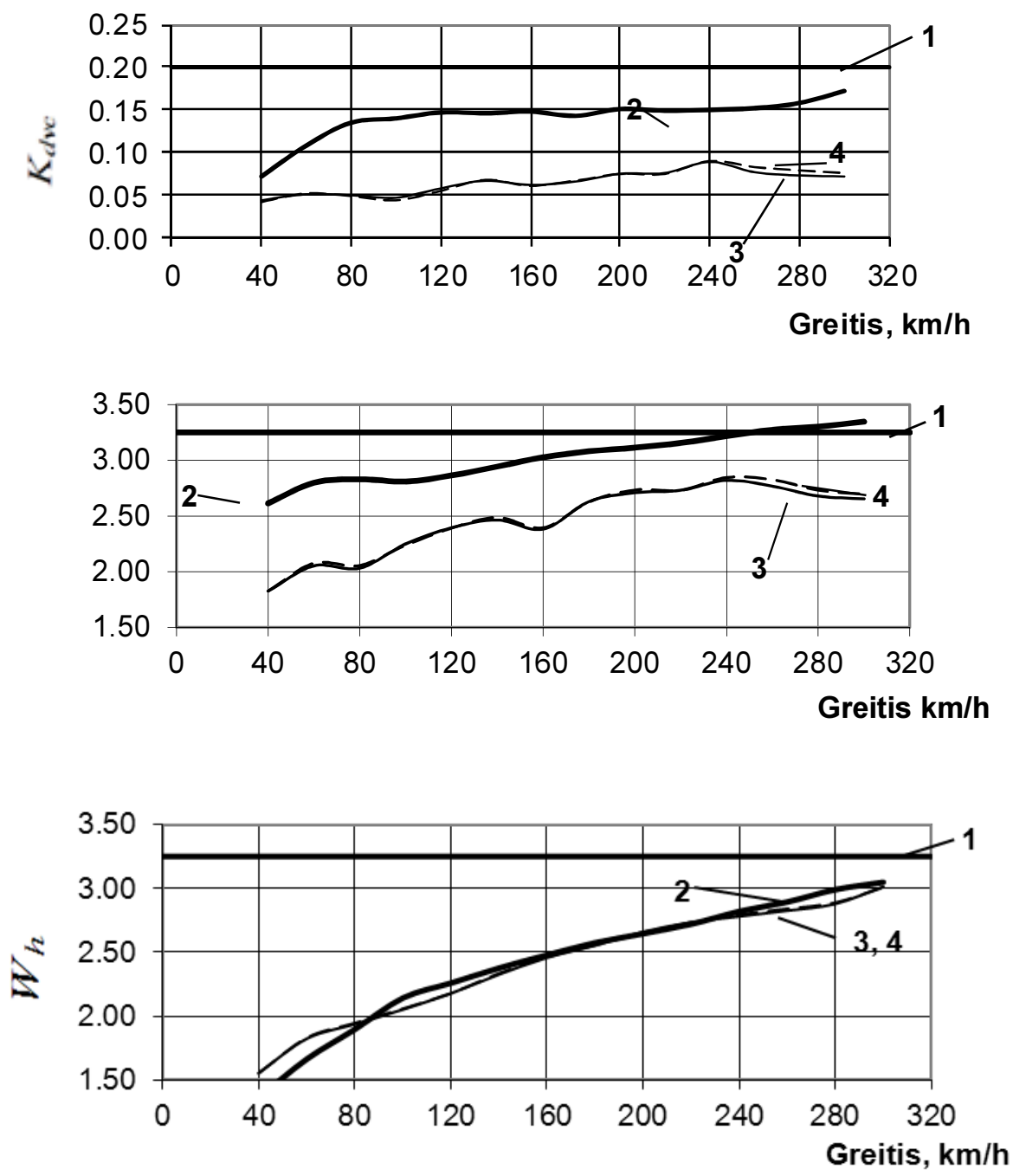

4.18 pav. Keleivinių vagonų dinaminiai rodikliai $K_{d v c}, W_{v}$ ir $W_{h}$

1 - dinaminių rodiklių leistinieji dydžiai; 2 -keleivinių vagonų su KVZ-CNII vežimèliais dinaminių rodiklių reikšmès; 3 - keleivinių vagonų 61-779 modelio su 68-7007 vežimèliais dinaminių rodiklių reikšmès; 4 - keleivinių vagonų 61-788 modelio su 68-7007 vežimèliais dinaminių rodiklių reikšmès

Fig. 4.18. Carriages dynamic characteristics $K_{d v c}, W_{v}$ ir $W_{h}$ :

1 - dynamic variables within limits; 2 - dynamic indicators to the carriages with KVZ-CNII trolley; 3 - dynamic indicators to the carriages 61-779 with 68-7007 trolley; 4 - dynamic indicators to the carriages $61-788$ with $68-7007$ trolley 


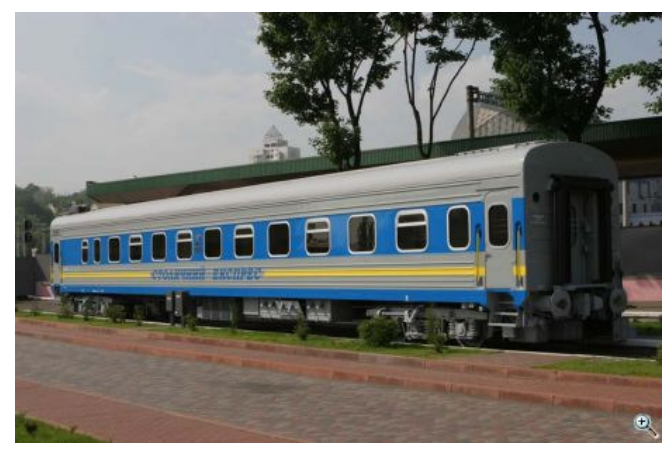

4.19 pav. 61-779 modelio keleivinis vagonas

Fig. 4.19. passenger carriage 61-779

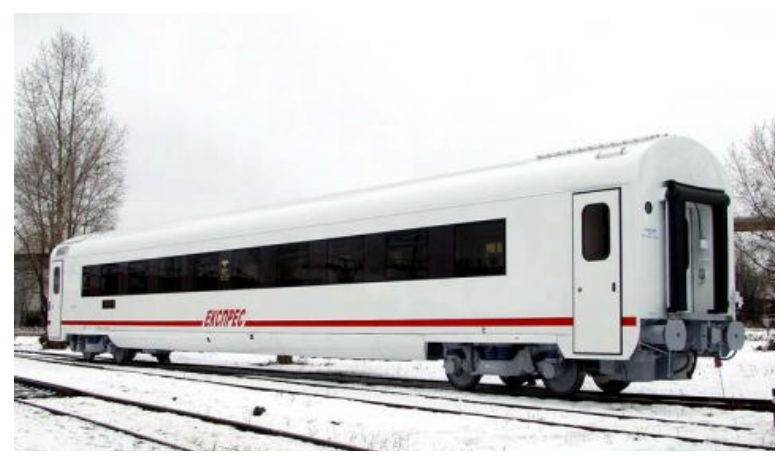

4.20 pav. 61-788 modelio keleivinis vagonas

Fig. 4.20. Passenger carriage 61-788

Tam tikslui buvo taikytas Monte Karlo metodas (Соболь 1979).

Dažnai ieškant optimalių ašidėžès ir centrinès pakabos parametrų reikšmių taikomas Neldero-Mido metodas (Лазарян, Коротенко, Данович 1966; Блохин, Данович, Морозов 1986; Мямлин 2002a) lokaliniams ekstremumams nustatyti. Todèl paieškos rezultatas labai priklauso ne tik nuo tikslo funkcijos paviršiaus tipo, bet ir nuo pradinių parametrų reikšmių, kurių srityje (aplinkoje) ieškomas sprendinys.

Pradžioje būtina ištirti (nustatyti) tikslo funkcijos tipa, o po to tose vietose, kur galima numanyti esanti tikslo funkcijos ekstremumą (minimuma), būtina atlikti paties ekstremumo paiešką. Visam tam reikia didelio skaičiuojamojo darbo, ypač tuomet, kai optimizuojamų parametrų gana daug. Pavyzdžiui, vienu metu ieškant ašidèžès ir centrinès pakabų optimalių parametrų reikšmių, jų yra 12. Ieškant numanomų ekstreminių sričių, būtina atlikti 8-10 skaičiavimų îvairioms kiekvieno parametro reikšmėms ir tik po to kiekvienai ,jtartinai“" sričiai rasti ekstremumą. Esant tokiam didžiuliam rezultatų skaičiui ganėtinai sunku 
parinkti pačius tinkamiausius. Juo labiau nèra garantijos, kad bus gautas tikrai optimalus sprendinys (kai kurios sritys vienaip ar kitaip liks neištirtos).

Tačiau ieškant ekstremumų naudojami ir apytikriai sprendimo metodai. Vienas iš tokių - Monte Karlo metodas (Соболь 1979). Jo esmè ta, kad optimizuojami parametrai parenkami pasirinktame diapazone atsitiktinai taip, kad tolygiai būtų perdengtas visas diapazonas. Po to iš gautų reikšmių atrenkamos tinkamiausios, kurios griežtai imant nèra optimalios, bet esant pakankamai imčiai artimos joms. Šio metodo privalumas tas, kad jis nereikalauja jokių išankstinių tikslo funkcijos tyrimų.

Atsižvelgiant $\mathfrak{i}$ anksčiau pasirinktos tikslo funkcijos ypatumus (Блохин, Данович, Морозов 1986; Мямлин 2002а; Вершинский, Данилов, Хусидов 1991) manoma, kad tikslinga būtų spręsti uždavinị didinant ribinį važiavimo greiti, pasirinkus ji dabar jau maksimizuota tikslo funkcija, o dinaminius važiuoklès kokybès rodiklius - kaip veiksnius, lemiančius ribinį važiavimo greitị.

Dinaminio uždavinio sprendimas. Šiam uždaviniui spręsti naudojama geležinkelio riedmenų dinaminių procesų modeliavimo programa buvo papildyta modeliu, realizuojančiu Monte Karlo algoritmą optimalių važiuoklès pakabos paremtu paieškai. Šiam metodui realizuoti pirmiausia reikia parinkti efektyvų atsitiktinių dydžiu generatorių su tolygiu pasiskirstymu. Tokiu generatoriumi gali būti algoritmas (Соболь 1979). Jis grindžiamas parametrų $s$ kaitos žingsnio parinkimu kaip paprasto skaičiaus kvadratinès šaknies trupmeninès dalies. Po to apskaičiuojamos optimizuojamų parametrų reikšmės pagal taisyklę:

$$
X_{i}=X_{\min }+\left(X_{\max }-X_{\min }\right) \cdot \delta_{i},
$$

čia $\delta_{i}=\left\{\begin{array}{l}\delta_{i-1}+s, \quad \text { jeigu } \delta_{i}<1 \\ \delta_{i-1}+s-1, \text { jeigu } \delta_{i}>1\end{array}\right\}$.

Siekiant, kad algoritmas efektyviai funkcionuotų, atsitiktinių dydžių $\delta_{i}$ seka turi greitai sueiti i tolygiai pasiskirsčiusią eilutę. Algoritmu (4.19) buvo gauta seka atsitiktinių dydžių. 4.21-4.23 pav. pateiktos pirmuju 10,50 ir 200 gautų atsitiktinių dydžių histogramos.

Kaip matyti iš pateiktų histogramų, jau po 50 atsitiktinių dydžiu jų pasiskirstymo dèsnis artèja prie tolygaus, o po 200 praktiškai ji galima laikyti esant tolygų.

Buvo atlikti vagono modelio 61-779 su vežimèliu 68-7007 skaičiavimai (2000 variantų) ir atrinkta 10 variantų ašidèžès pakabos parametrų. Gauti rezultatai pateikti 4.8 lenteleje. 


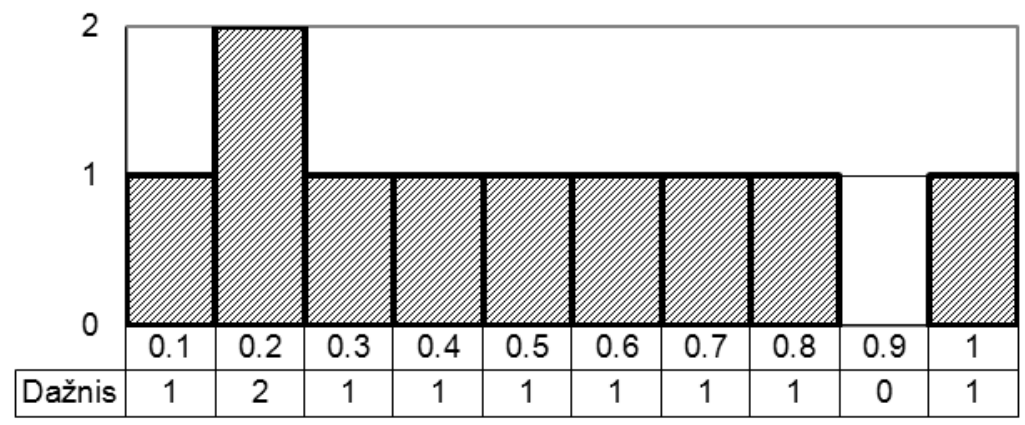

4.21 pav. Pirmujų 10 atsitiktinių dydžių histograma

Fig. 4.21. The first 10 random variables histogram

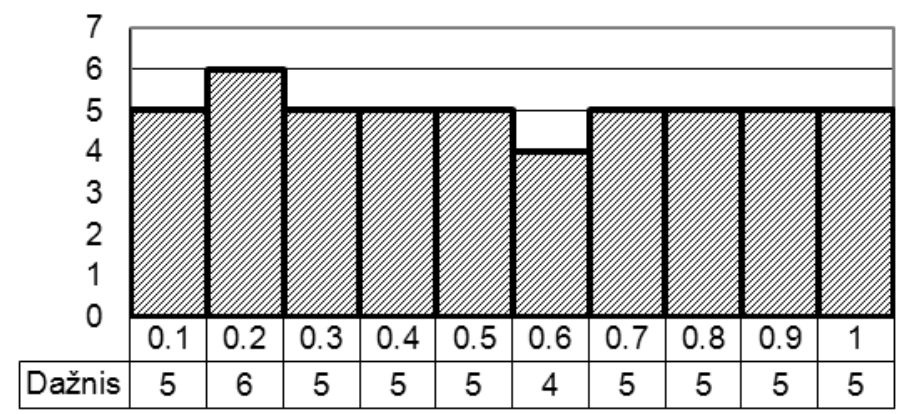

4.22 pav. Pirmujų 50 atsitiktinių dydžių histograma

Fig. 4.22. The first 50 random variables histogram

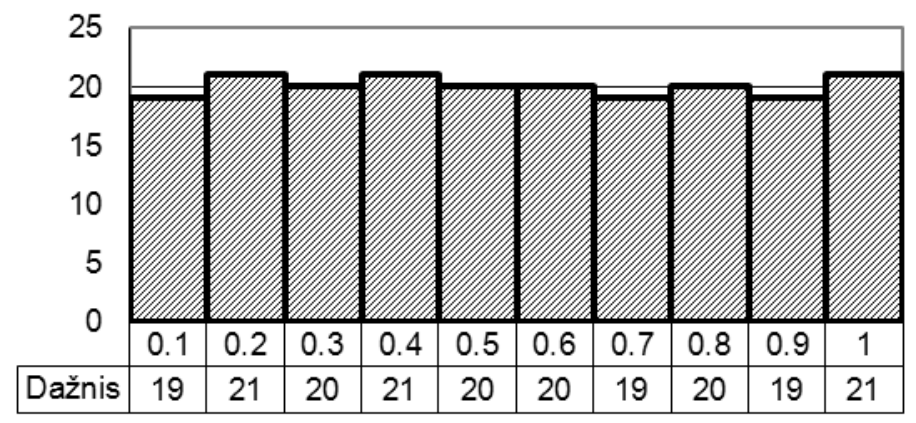

4.23 pav. Pirmujų 200 atsitiktinių dydžių histograma

Fig. 4.23. The first 200 random variables histogram 
4.8 lentelè. Ašidėžès pakabos parametrų variantai esant $300 \mathrm{~km} / \mathrm{h}$ greičiui

Table 4.8. Axle box suspension parameter variations at $300 \mathrm{~km} / \mathrm{h}$

\begin{tabular}{|c|c|c|c|c|c|c|}
\hline $\begin{array}{c}\text { Parametruc } \\
\text { variantai }\end{array}$ & $\begin{array}{c}K_{a x}, \\
\mathrm{kN} / \mathrm{m}\end{array}$ & $\begin{array}{c}V_{a x}, \\
\mathrm{kNs} / \mathrm{m}\end{array}$ & $\begin{array}{c}K_{a y}, \\
\mathrm{kN} / \mathrm{m}\end{array}$ & $\begin{array}{c}V_{a y}, \\
\mathrm{kNs} / \mathrm{m}\end{array}$ & $\begin{array}{c}K_{a z}, \\
\mathrm{kN} / \mathrm{m}\end{array}$ & $\begin{array}{c}V_{a z}, \\
\mathrm{kNs} / \mathrm{m}\end{array}$ \\
\hline $\mathrm{I}$ & 1290 & 27,4 & 255 & 12,6 & 1222 & 10,1 \\
\hline II & 436 & 99,2 & 247 & 7,9 & 1137 & 10,9 \\
\hline III & 1610 & 20,8 & 251 & 25,5 & 1791 & 8,4 \\
\hline $\mathrm{IV}$ & 1627 & 26,6 & 402 & 19,5 & 359 & 20 \\
\hline V & 1482 & 71,9 & 240 & 3,2 & 1051 & 11,8 \\
\hline VI & 756 & 92,6 & 243 & 20,9 & 1706 & 9,2 \\
\hline VII & 1793 & 30,9 & 419 & 8,7 & 1731 & 7 \\
\hline VIII & 1802 & 65,3 & 236 & 16,2 & 1620 & 10,1 \\
\hline IX & 939 & 3,7 & 412 & 4 & 1645 & 7,9 \\
\hline X & 948 & 38 & 228 & 11,5 & 1535 & 11 \\
\hline
\end{tabular}

Kadangi nustatant ašidėžių pakabos parametrus buvo atlikti skaičiavimai esant $300 \mathrm{~km} / \mathrm{h}$ greičiui, būtina atlikti patikrinamuosius skaičiavimus visam greičių diapazonui. Tokių skaičiavimų rezultatas - reikia atmesti tuos variantus, kur dinaminiai rodikliai viršija leistinas ribas, kai važiavimo greičiai mažesni nei $300 \mathrm{~km} / \mathrm{h}$.

Patikrinamujų rezultatų skaičiavimai pateikti priede (L1-L10 lentelèse).

Iš L1-L10 lentelèse pateiktų rezultatų matyti, kad didesné dauguma parametrų variantų neatitinka ribojimų pagal $K_{d v a}$. Ribinès $K_{d v a}$ reikšmès, viršijančios leistinąsias ribas, lentelëje pažymètos pusjuodžiu šriftu. Tinkami tolesniems tyrimams pasirode trys variantai (I, II ir V). Šiems variantams (4.24 ir 4.25 pav.) parodyti dinaminių rodiklių grafikai. Šie trys variantai mažai skiriasi vienas nuo kito. Nedidelis $K_{s}$ ir $K_{\text {dha }}$ reikšmių skirtumas negali būti pirmumo kriterijumi pasirenkant vieną iš jų, nes šių rodiklių reikšmès visiems variantams tolimos nuo leistinujų reikšmių.

Skaičiuojant programa leido patikrinti ir ratų riedėjimo paviršiaus, ir antbriaunio išsidèvejimą priklausomai nuo greičio.

Apibendrinus rezultatus, galima teigti, kad, esant keleiviniu vagonu greičiams iki $300 \mathrm{~km} / \mathrm{h}$, pirmiausia dèl ratu susidèvejimo ir išlaidu traukinio traukai labiausiai tinka ašidèžiu pakabos parametrai, atitinkantys pirmaji varianta, pateikta L1 lenteleje (priedas). 

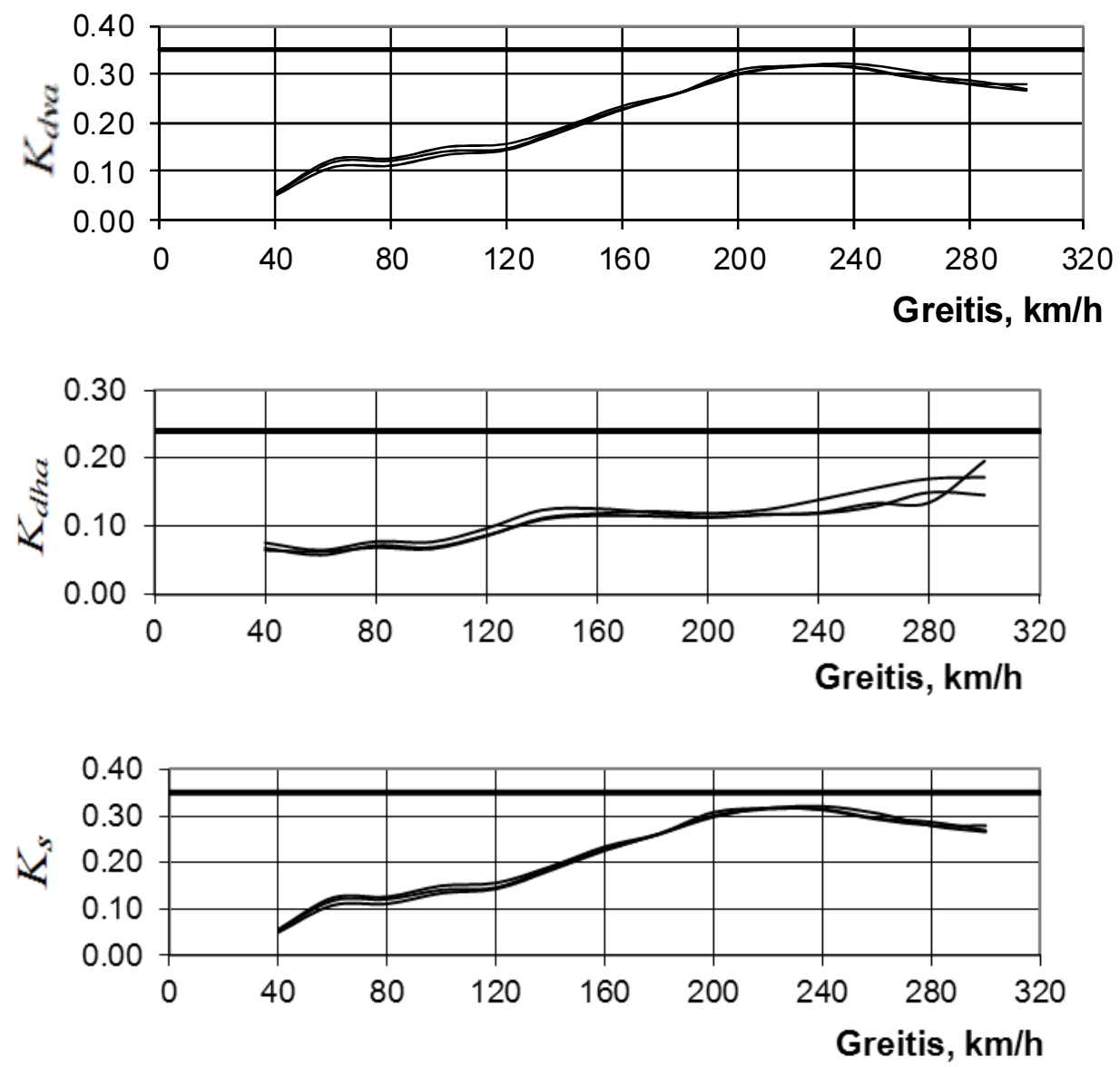

4.24 pav. 68-779 modelio keleivinių vagonų dinaminiai rodikliai $K_{d v a}, K_{d h a}$ ir $K_{s}$ Fig. 4.24. Model 68-779 passenger carriage dynamic indicators $K_{d v a}, K_{d h a}$ ir $K_{s}$ 

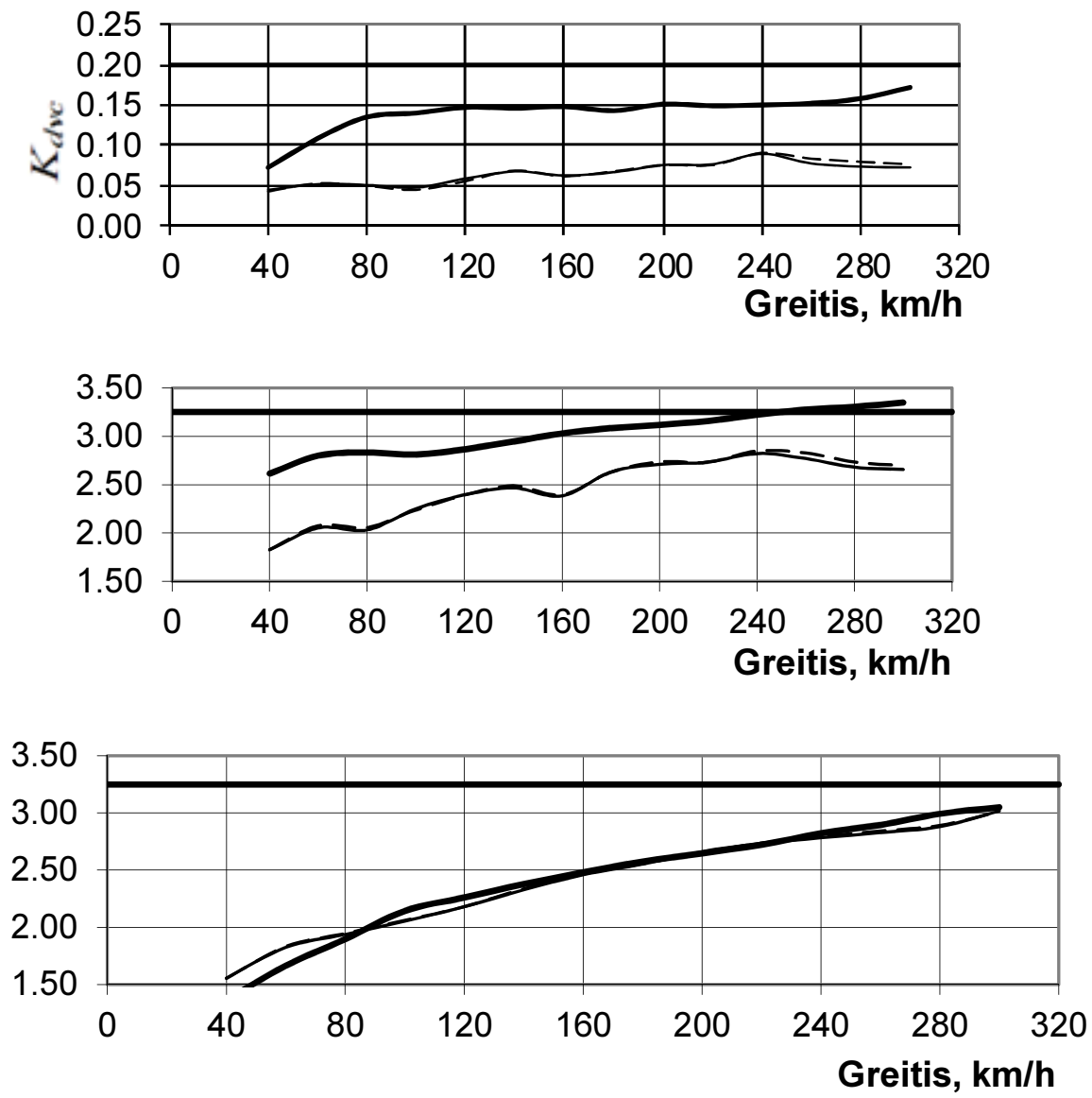

4.25 pav. 68-779 modelio keleivinių vagonų dinaminiai rodikliai $K_{d v c}, W_{v}$ ir $W_{h}$ Fig. 4.25. Model 68-779 passenger carriage dynamic indicators $K_{d v c}, W_{v}$ ir $W_{h}$

\subsubsection{Pakabos elementų tikrinimas}

Pagal galiojančias normas (Нормы для расчета... 1996) būtina atlikti naujos vežimèlio pakabos įvertinimą esant atitinkamiems (maksimaliems) greičiams. Paprastai būtina nustatyti standumus, ịlinkius, itempius pakabos spyruoklèse, stovumus, kai ašies apkrova i bègi yra 161,865 kN.

Atliekami centrinès 68-7007 vežimèlio pakabos pagal I ir III režimus skaičiavimai. Eksploatuojant keleivinius vagonus, I režimą atitinka avariniai susidūrimai manevruojant arba vagonų susidūrimai nestandartinèse situacijose, taip pat avarinis vagono šuolis (smūgis), kai jis yra prikabintas prie krovininio traukinio.

Skaičiuojant pagal III režimą ivvertinamas dažnai galimas vidutinių apkrovų reikšmių derinys, kuris būdingas judančio traukinio vagonui. 
Pagrindinis reikalavimas - neleisti subyrèti mazgams ir detalèms dèl nuovargio. Leistinieji itempiai parenkami atsižvelgiant i medžiagų nuovargio ribas, ivertinant kartu veikiančias kvazistatines, vibracines ir smūgines jègas, korozijos poveiki ir pan. Eksploatacijos sąlygomis III skaičiuojamasis režimas atitinka atvejus, kai vagonas juda traukinyje kelio tiesėmis ir kreivèmis, per iešmus leidžiamu greičiu ir periodiškai atliekamas pakopinis stabdymas, kai veikia norminiai trūkčiojimai ir pastūmimai, kitaip tariant, kai visi vagono mazgai ir mechanizmai dirba norminiu režimu.

Atliekami naujos konstrukcijos 68-7007 vežimèlio centrinès pakabos skaičiavimai. Skaičiavimo seka ir rezultatai pateikti 4.9 ir 4.10 lentelèse.

4.9 lentelè. Atsparumo skaičiavimas I režimu

Table 4.9. I mode strenght counting

\begin{tabular}{|c|c|c|}
\hline Formulè & Pavadinimas & $\begin{array}{c}\text { Skaičiuojamieji } \\
\text { duomenys }\end{array}$ \\
\hline 1 & 2 & 3 \\
\hline \multicolumn{3}{|c|}{ Statinè vienos spyruoklès apkrova } \\
\hline$P_{s t}=\frac{\left(m_{b r}-m_{v e \check{z}}\right) 9,81}{k n}$ & $\begin{array}{l}m_{b r}=66 \mathrm{t}-\text { vagono masé bruto; } \\
m_{v e \check{z}}=13,2 \mathrm{t}-\text { vežimèlio masé; } \\
k=2-\text { vežimèlių skaičius; } \\
n=4 \text { - spyruoklių skaičius }\end{array}$ & $64745 \mathrm{kN}$ \\
\hline \multicolumn{3}{|c|}{ Spyruoklių duomenys } \\
\hline & $\begin{array}{l}d=0,043 \mathrm{~m}-\text { strypelio skersmuo; } \\
D=0,252 \mathrm{~m} \text { - spyruoklès vidutinis } \\
\text { skersmuo; } \\
n=8,6 \text { - darbo vijų skaičius }\end{array}$ & \\
\hline$H_{\text {sus }}=d(n+1)+0,003$ & Suspaustos spyruoklès aukštis & $0,416 \mathrm{~m}$ \\
\hline$C_{v}=\frac{G d^{4} \Psi}{8 D^{3} n}$ & $\begin{array}{c}\begin{array}{c}\text { Suspaustos cilindrinės spyruoklès } \\
\text { vertikalusis standumas: }\end{array} \\
G=8 \cdot 10^{4} \mathrm{MPa}-\text { šlyties modulis; } \\
\Psi-\text { koeficientas, } \Psi \approx \cos ^{2} \alpha, \text { čia } \\
\alpha=3,76^{\circ}-\text { apkrautos spyruoklès } \\
\text { sraigtinès linijos pokylio kampas }\end{array}$ & $245,254 \mathrm{kN}$ \\
\hline$C_{c}=\frac{D}{d}$ & Centrinès spyruoklès indeksas & 5,86 \\
\hline$f_{s t}=\frac{P_{s t}}{C_{v}}$ & Illinkio dydis nuo statinès apkrovos & $0,264 \mathrm{~m}$ \\
\hline$f_{p}=K f_{s t}$ & Didžiausias skaičiuojamasis įlinkis & $0,392 \mathrm{~m}$ \\
\hline$H_{l b}=H_{s u s}+f_{p}$ & Spyruoklès aukštis esant laisvos padèties & $0,812 \mathrm{~m}$ \\
\hline
\end{tabular}


4.9 lentelès pabaiga

\begin{tabular}{|c|c|c|}
\hline 1 & 2 & 3 \\
\hline \multicolumn{3}{|c|}{ Itempiai spyruoklèje nuo vertikaliosios apkrovos } \\
\hline$\tau_{v}=\frac{8 P_{p} D \xi}{\pi d^{3}}$ & $\begin{array}{l}\text { Centrinės pakabos spyruoklès skaičiavi- } \\
\text { mas stiprumui nuo vertikaliosios apkrovos: }\end{array}$ & \\
\hline$P_{p}=C_{v} f_{p}$ & $\begin{array}{l}\text { Vertikalioji skaičiuojamoji jèga: } \\
C_{v}=245,254 \mathrm{kN} / \mathrm{m}-\text { spyruoklès } \\
\text { vertikalusis standumas; } \\
f_{p}=0,396 \mathrm{~m}-\text { maksimalus } \\
\text { skaičiuojamasis spyruoklès įlinkis }\end{array}$ & $97,121 \mathrm{kN}$ \\
\hline$\xi=1+\frac{1,250}{C_{c}}+\frac{0,875}{C_{c}^{2}}$ & Pataisos koeficientas & 1,239 \\
\hline$\tau_{v}$ & Itempiai spyruoklèje & $971 \mathrm{MPa}$ \\
\hline \multicolumn{3}{|c|}{$\begin{array}{l}\text { Leistinieji įtempiai spyruoklëje (plienas 65C2BA) } \tau<[\tau]=1133 \mathrm{MPa} \text {. } \\
\text { Skaičiuojamieji įtempiai spyruoklèje } \tau_{v}=971 \mathrm{MPa} \text {. } \\
971<1133 \text {. }\end{array}$} \\
\hline
\end{tabular}

4.10 lentelè. Atsparumo skaičiavimas III režimu

Table 4.10. III mode strenght counting

\begin{tabular}{|c|c|c|}
\hline Formulè & Pavadinimas & $\begin{array}{l}\text { Skaičiuojamieji } \\
\text { duomenys }\end{array}$ \\
\hline 1 & 2 & 3 \\
\hline \multicolumn{3}{|c|}{ Vienos spyruoklès apkrova } \\
\hline$P=P_{s t}+P_{d i n}+0,5 P_{\check{s} o n} / 4$ & $\begin{array}{l}P_{s t}=64,746 \mathrm{kN}-\text { statinè vienos } \\
\text { spyruoklès apkrova }\end{array}$ & \\
\hline$P_{d i n}=P_{s t} K_{d v}$ & $\begin{array}{l}\text { Vertikali dinaminè spyruoklès } \\
\text { apkrova }\end{array}$ & $12,3 \mathrm{kN}$ \\
\hline$P_{\check{s} o n}=0,1 P_{s t}$ & $\begin{array}{l}\text { Dalis šoninės jègos, veikiančios vie- } \\
\text { ną spyruoklę }\end{array}$ & $6,475 \mathrm{kN}$ \\
\hline$K_{d v}=\frac{\bar{K}_{d v}}{\beta} \sqrt{\frac{4}{\pi}} \ln \frac{1}{1-P\left(K_{d v}\right)}$ & $\begin{array}{l}\text { Vertikalios dinamikos koeficientas: } \\
\beta \text { - keleivinių vagonu pasiskirstymo } \\
\text { parametras, } \beta=1 \text {; } \\
P\left(K_{d v}\right)=0,97 \text { - patikimumo tiki- } \\
\text { mybė, skaičiuojant pagal leistinuo- } \\
\text { sius įtempius }\end{array}$ & 0,19 \\
\hline
\end{tabular}


4.10 lentelès tęsinys

\begin{tabular}{|c|c|c|}
\hline 1 & 2 & 3 \\
\hline $\bar{K}_{d v}=a+3,6 \cdot 10^{-4} b \frac{v 15}{f_{s t}}$ & 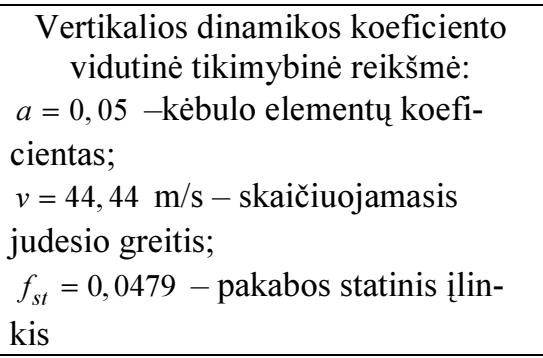 & 0,09 \\
\hline$b=\frac{n+2}{2 n}$ & $\begin{array}{l}\text { Koeficientas, ivertinantis ašių skaičių } \\
\qquad n \text { vežimėlyje }\end{array}$ & 1 \\
\hline$P_{I I I}=P_{s t}+P_{\text {din }}+P_{\text {šon }} / 2$ & Apkrova, tenkanti spyruoklei & $83,523 \mathrm{kN}$ \\
\hline \multicolumn{3}{|c|}{ Ittempiai spyruoklèje nuo vertikaliosios apkrovos } \\
\hline$\tau_{v}=\frac{8 P_{p} D \xi}{\pi d^{3}}$ & $\begin{array}{c}\text { Spyruoklès stiprumo skaičiavimas } \\
\text { nuo vertikaliosios apkrovos: } \\
P_{p}-\text { vertikalioji skaičiuojamoji jèga }\end{array}$ & \\
\hline$\xi=1+\frac{1,250}{C_{c}}+\frac{0,875}{C_{c}^{2}}$ & Pakabos koeficientas & 1,239 \\
\hline$\tau_{v}$ & İtempiai spyruoklèje & $835 \mathrm{MPa}$ \\
\hline \multicolumn{3}{|c|}{ Horizontalusis spyruoklès standis } \\
\hline \multirow{2}{*}{$C_{h}=\frac{3 E d^{4}}{8 D n\left[H^{2}(2+\mu)+3 D^{2}\right.}$} & $\begin{array}{c}\text { Cilindrinis spyruoklès horizontalusis } \\
\text { standis, kai vienu metu ją veikia } \\
\text { horizontalioji ir vertikalioji apkro- } \\
\text { vos: }\end{array}$ & \\
\hline & $\begin{array}{l}E=2,1 \cdot 10^{11} \mathrm{~Pa}-\text { spyruoklès me- } \\
\text { džiagos tamprumo modulis; } \\
\mu=0,3 \text { - Puasono koeficientas }\end{array}$ & \\
\hline$H=H_{l b}-d-f_{p}$ & $\begin{array}{c}\text { Spyruoklès aukštis veikiant } \\
\text { vertikaliajai apkrovai }\end{array}$ & $0,43 \mathrm{~m}$ \\
\hline$C_{h}$ & Spyruoklès horizontalusis standis & $201,743 \mathrm{~N} / \mathrm{m}$ \\
\hline \multicolumn{3}{|c|}{ İtempiai spyruoklėse nuo horizontaliosios apkrovos } \\
\hline$\tau_{h}=\frac{5 T}{x d^{3}} \xi^{\prime} \operatorname{tg} \frac{x H}{2}$ & $\begin{array}{l}\text { Cilindrinė sraigtinè spyruoklè nuo } \\
\quad \text { horizontaliosios jègos: } \\
T \text { - skaičiuojamoji horizontalioji } \\
\text { jèga, veikianti spyruoklę, nustatoma } \\
\text { kaip } 50 \% \text { šoninès vagono jègos; } \\
H \text { - spyruoklès, apkrautos vertikalią- } \\
\text { ja apkrova, aukštis }\end{array}$ & \\
\hline
\end{tabular}


4.10 lentelès pabaiga

\begin{tabular}{|c|c|c|}
\hline 1 & 2 & 3 \\
\hline$\xi^{\prime}=1+\frac{0,63}{C_{c}}+\frac{0,35}{C_{c}^{2}}$ & Pataisos koeficientas & 1,118 \\
\hline$T=\frac{0,1\left(m_{b r}-m_{v e z ̌ z}\right) 9,81}{4}$ & $\begin{array}{l}\begin{array}{l}\text { Skaičiuojamoji šoninè jèga, veikianti } \\
\text { viena spyruoklę: }\end{array} \\
m_{b r}=66 \mathrm{t}-\text { vagono bruto masé; } \\
m_{v e z ̇}=13,2 \mathrm{t} \text { - vežimèlio masė; } \\
n_{m}=4-\text { spyruoklių skaičius } \\
\text { vežimėlyje }\end{array}$ & $6,475 \mathrm{kN}$ \\
\hline$\delta=\frac{T}{C_{h}}$ & Spyruoklės horizontalus ịlinkis & $0,032 \mathrm{~m}$ \\
\hline $\operatorname{tg} \alpha=\frac{H}{\pi D n}$ & $\begin{array}{l}\text { Sraigtinès linijos pokylio kampas, } \\
\text { esant suspaustai spyruoklei }\end{array}$ & $0,0632 \mathrm{rad}$ \\
\hline$I=\frac{\pi d^{4}}{64}$ & $\begin{array}{l}\text { Strypelio inercijos momentas } \\
\text { lenkiant }\end{array}$ & $1,67 \cdot 10^{-7} \mathrm{~m}^{4}$ \\
\hline$\eta=\frac{2+\mu \cos ^{2} \alpha}{2 \sin \alpha}$ & Koeficiento $\eta$ reikšmė & 18,199 \\
\hline$B=\frac{E I}{\eta}$ & Koeficiento $B$ reikšmè & $1927,03 \mathrm{~m}^{2}$ \\
\hline$S=\frac{8 E I \cdot \operatorname{tg} \alpha}{D^{2}}$ & Koeficiento $S$ reikšmė & $2,79 \cdot 10^{5} \mathrm{~N}$ \\
\hline$X=\sqrt{\frac{P_{p}}{B\left(1-\frac{P_{p}}{S}\right)}}$ & Koeficiento $X$ reikšmè & $7,871 / \mathrm{m}$ \\
\hline$\tau_{h}$ & $\begin{array}{l}\text { Itempiai spyruoklèje nuo horizonta- } \\
\text { liosios apkrovos }\end{array}$ & $-475 \mathrm{MPa}$ \\
\hline$\tau=\tau_{v}+\tau_{h}$ & $\begin{array}{c}\text { Suminiai ịtempiai centrinès pakabos } \\
\text { spyruokleje pagal III režimą }\end{array}$ & $360 \mathrm{MPa}$ \\
\hline \multicolumn{3}{|c|}{$\begin{array}{l}\text { Suminiai leistinieji įtempiai spyruokleje (plienas } 65 \mathrm{C} 2 \mathrm{BA} \text { ) }[\tau]=1133 \mathrm{MPa} \text {. } \\
\text { Suminiai skaičiuojamieji ịtempiai spyruoklèje } \tau=360 \mathrm{MPa} \text {. } \\
\tau<[\tau] \text {. }\end{array}$} \\
\hline
\end{tabular}

Reikia atlikti ir centrinès pakabos spyruoklès patikrinimą stovumui. 
Norint užtikrinti apskritojo skerspjūvio spyruoklių dirbančiu suspaudimu, stovumą, santykis $H_{l b}$ (laisvos būklès spyruoklès aukštis) su jos skersmeniu $D$ turi būti mažesnis už kritini, nustatomą formule:

$$
\left(\frac{H_{l b}}{D}\right)_{k r}=\sqrt{\eta \frac{2-\frac{1}{1+\mu}}{1+\frac{1}{1+\mu}}},
$$

čia: $\eta=4 \pi^{2}-$ koeficientas, priklausantis nuo galinių spyruoklès vijų tvirtinimo būdo (abu galai kietai ittvirtinti); $\mu=0,3$ - Puasono koeficientas.

$$
\left(\frac{H_{l b}}{D}\right)_{k r}=\sqrt{39,48 \frac{2-\frac{1}{1+0,3}}{1+\frac{1}{1+0,3}}}=5,24 .
$$

Šiuo atveju:

$$
\left(\frac{H_{l b}}{D}\right)=\frac{0,812}{0,252}=3,22 \leq\left(\frac{H_{l b}}{D}\right)_{k r}=5,24 .
$$

Taigi sąlyga tenkinama.

Ivertinus technologinius gamybos netikslumus ir sudètinga pakabos spyruoklių apkrova, būtina numatyti pakankamą stovumo atsargą. Rekomenduojama imti:

$$
\left(\frac{H_{l b}}{D}\right) \leq 3,5 \text {. }
$$

Skaičiuojamuoju atveju:

$$
\left(\frac{H_{l b}}{D}\right)=\frac{0,812}{0,252}=3,22 \leq 3,5 .
$$

Stovumo salyga, ivertinus atsarga, taip pat tenkinama.

Remiantis šia metodika ir naudojantis literatūra (Нормы для расчета... 1996) ir (Манашкин, Мямлин, Приходько 2007), galima patikrinti ašidezžiu pakabų spyruokliu atsparumą I ir III režimams.

Nors pagrindine komforto gerinimo sąlyga yra virpesių mažinimas, tačiau yra ir kitu priemonių, gerinančių keleivių savijautą keleiviniuose vagonuose, ypač sėdimujų vietu irangą (priedas). 


\subsection{Eksperimentiniai tyrimai}

Noredama pritraukti daugiau keleiviu i geležinkelių transportą AB „Lietuvos geležinkeliai“" jau keletą metu pagal savo finansines galimybes stengiasi naujinti keleivinių riedmenų parką naujais dyzeliniais, elektriniais traukiniais bei automotrisèmis. Pastaraisiais metais modernizuota 20 keleivinių vagonų issigyti būtini nauji keleiviniai šilumvežiai, du nauji elektriniai traukiniai, dvi automotrisès. Užsakant naujus keleivinius riedmenis, techninès užduotys konkursams, t. y. būsimiems tiekejams, sudaromos remiantis 4.1 skyriuje pateikto važiuoklių dinaminių rodiklių skaičiavimo metodika bei reikalaujamomis tolygios eigos koeficiento reikšmėmis visame numatomame riedmenų eksploatavimo greičių diapazone, nes šis rodiklis yra pagrindinè gero keleivių komforto sąlyga. Gamintojui, laimejjusiam konkursa, pateikus riedmenis privaloma tvarka (nepaisant to, kad jie buvo sertifikuoti gamykloje) tikrinami pirmiausia tolygios eigos parametrai. Kartu patikrinamas ir mūsų teorinio modelio (4.9) korektiškumas. Autoriui dalyvaujant elektrinio traukinio EJ 575 bandymuose nustatyta, kad praktiniu bandymų rezultatai gerai koreliuoja su apskaičiuotais $( \pm 1,7)$, t. y. tolygios eigos koeficientas neviršijo leistinujų (reikalaujamų) ribų. 4.11 ir 4.12 lentelèse pateikiami rezultatai bandyto elektrinio dviaukščio traukinio EJ575 Kaišiadorių-Pravieniškių ruože. Rezultatai gauti matuojant skersinius ir vertikalius pagreičius tarpiniame pakrautame vagone pagal schemą, parodytą 4.26 pav.

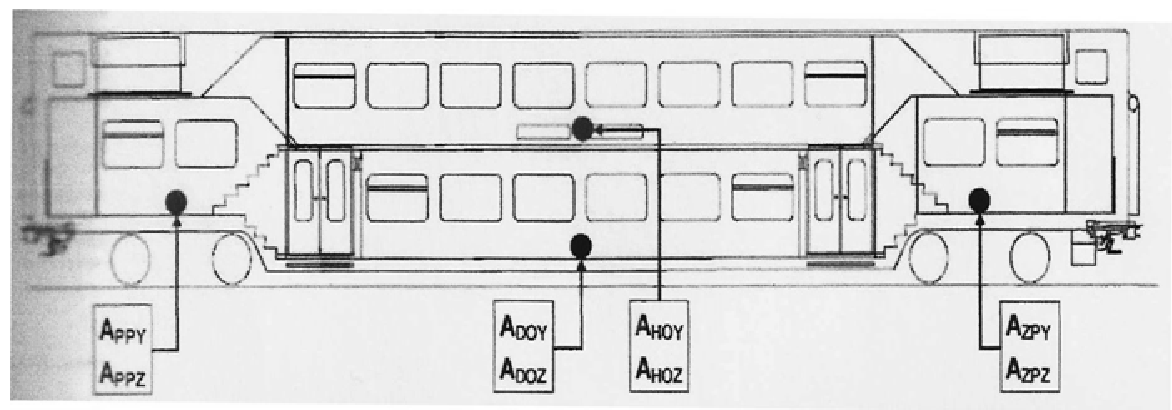

4.26 pav. Pagrindinių jutiklių išdèstymo ant tarpinio vagono grindų schema Fig. 4.26. Scheme of main sensors layout on the intermediate carriage floor

Čia $A_{P P Y}, A_{P P Z}, A_{D O Y}, A_{D O Z}, A_{H O Y}, A_{H O Z}, A_{Z P Y}, A_{Z P Z}-$ atitinkamai priekinio vežimèlio, I aukšto, II aukšto ir galinio vežimèlio zonose sumontuoti horizontaliujų ir vertikaliujų pagreičių jutikliai. 
4.11 lentelè. Tarpinio vagono, turinčio pakabą su oro pagalve, tolygios eigos koeficientų $W$ reikšmès

Table 4.11. Smooth motion weights $W$ of the interjacent carriage with air suspension

\begin{tabular}{|c|c|c|c|c|c|}
\hline \multicolumn{2}{|c|}{ Judėjimo kryptis } & \multicolumn{4}{|c|}{ Kaišiadorys-Pravieniškès } \\
\hline Greitis & $\mathrm{km} / \mathrm{val}$. & 59,8 & 79,8 & 99,6 & 119,6 \\
\hline Kelias & $\mathrm{m}$ & 2028,2 & 1939,4 & 2083,6 & 1893,0 \\
\hline \multicolumn{6}{|l|}{$\begin{array}{l}\text { Matavimo } \\
\text { vieta }\end{array}$} \\
\hline \multirow{2}{*}{$\begin{array}{l}\text { Priekinis } \\
\text { vežimėlis }\end{array}$} & $W_{h}$ & 1,06 & 1,44 & 1,51 & 1,44 \\
\hline & $W_{v}$ & 1,35 & 1,83 & 2,06 & 1,91 \\
\hline \multirow[t]{2}{*}{ I aukštas } & $W_{h}$ & 0,90 & 1,28 & 1,38 & 1,35 \\
\hline & $W_{v}$ & 1,45 & 2,23 & 2,12 & 2,17 \\
\hline \multirow{2}{*}{$\begin{array}{l}\text { Galinis } \\
\text { vežimèlis }\end{array}$} & $W_{h}$ & 1,05 & 1,45 & 1,49 & 1,42 \\
\hline & $W_{v}$ & 1,32 & 1,86 & 2,06 & 1,78 \\
\hline \multirow[t]{2}{*}{ II aukštas } & $W_{h}$ & 1,09 & 1,41 & 1,37 & 1,30 \\
\hline & $W_{v}$ & 1,29 & 1,91 & 2,05 & 2,00 \\
\hline
\end{tabular}

4.12 lentelè. Tarpinio vagono su avarine (spyruokline) pakaba tolygios eigos koeficientu $W$ reikšmès

Table 4.12. Smooth motion weights $W$ of the interjacent carriage with emergency (spring) suspension

\begin{tabular}{|l|c|c|c|c|c|}
\hline \multicolumn{2}{|c|}{ Judèjimo kryptis } & \multicolumn{4}{c|}{ Kaišiadorys-Pravieniškès } \\
\hline \multicolumn{1}{|c|}{ greitis } & $\mathbf{k m} / \mathbf{v a l}$. & $\mathbf{5 9 , 6}$ & $\mathbf{7 9 , 7}$ & $\mathbf{9 9 , 6}$ & $\mathbf{1 1 9 , 6}$ \\
\hline \multicolumn{1}{|c|}{ kelias } & $\mathrm{m}$ & 2077,0 & 1934,3 & 1963,0 & 1917,3 \\
\hline $\begin{array}{l}\text { Matavimo } \\
\text { vietai }\end{array}$ & \multicolumn{5}{|c|}{} \\
\hline $\begin{array}{l}\text { Priekinis } \\
\text { vežimėlis }\end{array}$ & $\boldsymbol{W}_{\boldsymbol{h}}$ & 1,20 & 1,60 & 1,69 & 1,56 \\
\hline & $\boldsymbol{W}_{\boldsymbol{v}}$ & 1,69 & 2,18 & 2,54 & 2,17 \\
\hline I aukštas & $\boldsymbol{W}_{\boldsymbol{h}}$ & 1,05 & 1,39 & 1,48 & 1,43 \\
\hline & $\boldsymbol{W}_{\boldsymbol{v}}$ & 1,80 & 2,42 & 2,29 & 2,18 \\
\hline $\begin{array}{l}\text { Galinis } \\
\text { vežimėlis }\end{array}$ & $\boldsymbol{W}_{\boldsymbol{h}}$ & 1,24 & 1,64 & 1,78 & 1,58 \\
\hline & $\boldsymbol{W}_{\boldsymbol{v}}$ & 1,80 & 2,12 & 2,40 & 2,15 \\
\hline II aukštas & $\boldsymbol{W}_{\boldsymbol{h}}$ & 1,28 & 1,60 & 1,57 & 1,39 \\
\hline & $\boldsymbol{W}_{\boldsymbol{v}}$ & 1,75 & 2,18 & 2,17 & 2,05 \\
\hline
\end{tabular}

4.11-4.12 lentelių duomenys pateikti 4.27-4.30 pav 


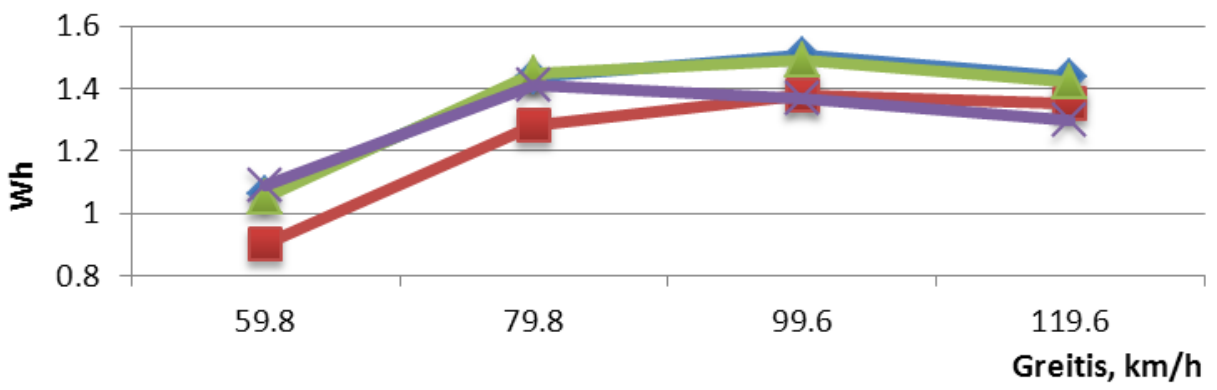

$\leadsto$ Priekinis vežimèlis $\leadsto$ laukštas $\leadsto$ Galinis vežimèlis $\longleftrightarrow$ ll aukštas

4.27 pav. Tarpinio vagono, turinčio pakabą su oro pagalve, $W_{h}$ priklausymas nuo greičio

Fig. 4.27. Dependence of the interjacent carriage with spring suspension $W_{h}$ from travel speed

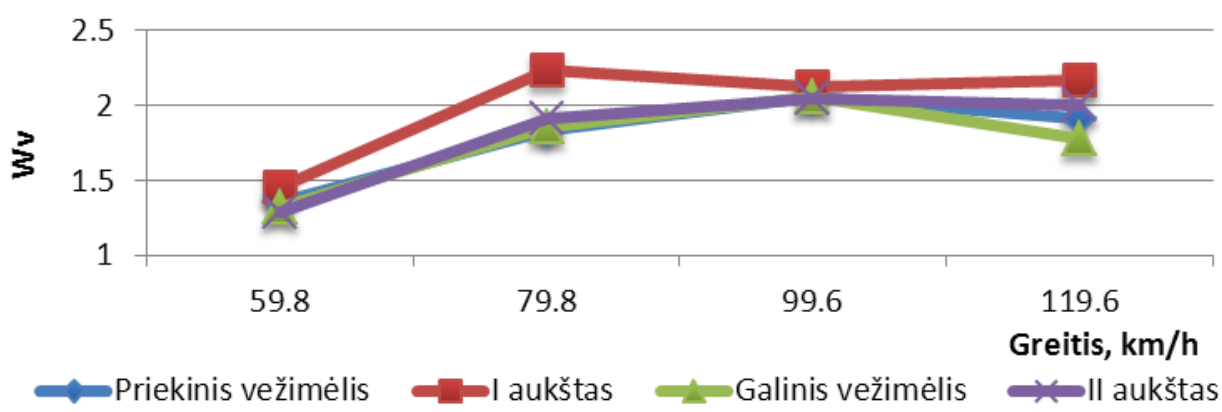

4.28 pav. Tarpinio vagono, turinčio pakabą su oro pagalve,

$W_{v}$ priklausymas nuo greičio

Fig. 4.28. Dependence of the interjacent carriage with air suspension $W_{v}$ from travel speed

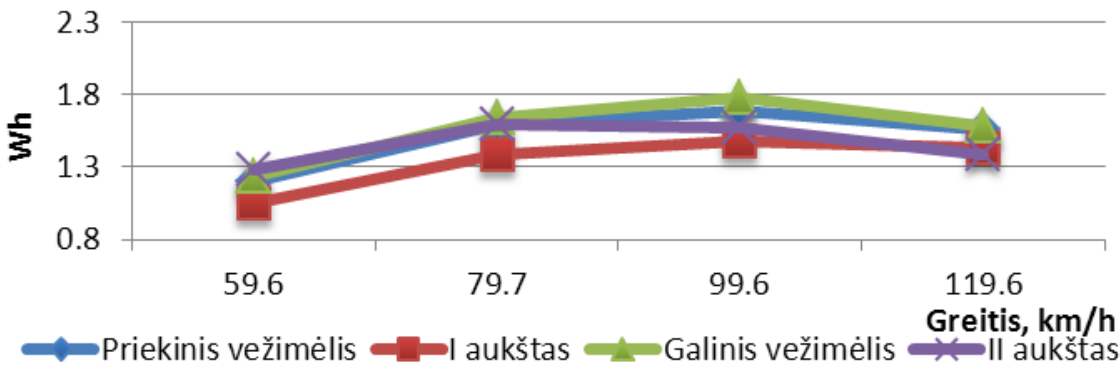

4.29 pav. Tarpinio vagono su spyruokline pakaba $W_{h}$ priklausymas nuo greičio Fig. 4.29. Dependence of the interjacent carriage with spring suspension $W_{h}$ from travel speed 


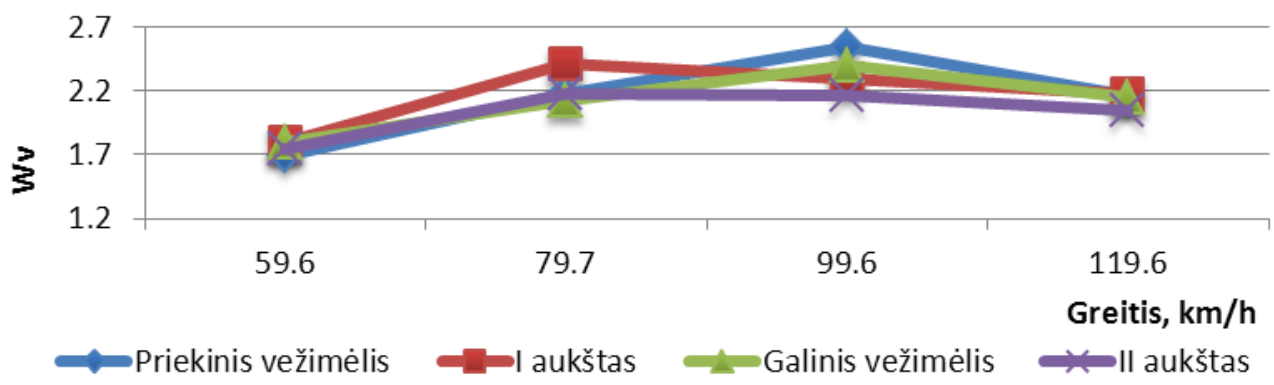

4.30. pav. Tarpinio vagono su spyruokline pakaba $W_{v}$ priklausymas nuo greičio

Fig. 4.30. Dependence of the interjacent carriage with spring suspension $W_{v}$ from travel speed

Kaip matyti iš 4.27 ir 4.28 pav., esant oro pagalvei greičių diapazone nuo 60 iki $120 \mathrm{~km} / \mathrm{h} W_{h}$ tesiekia vos 1,5 , o $W_{v}$ esant greičiui $80 \mathrm{~km} / \mathrm{h}$ šiek tiek viršija reikšmę 2,0. Tai irgi labai geras rodiklis.

Bandant vadinamają avarinę (spyruoklinę) pakabą, iš 4.29 ir 4.30 pav. matyti, kad horizontalus $W_{h}$ galinio vežimèlio zonoje didžiausias, bet neviršija 1,75 reikšmés, o $W_{v}$ reikšmè (4.30 pav.) galinio vežimèlio zonoje, esant $100 \mathrm{~km} / \mathrm{h}$ greičiui, igauna maksimalią reikšmę ir siekia apie 2,5 , tai irgi vertinama kaip labai gera reikšmè. Ribinè keleivinių vagonų $W_{v}$ reikšmé yra 3,0-3,25. Taigi gamintojas neperžengè techninèse sąlygose nurodytų tolygios eigos koeficiento reikšmių.

Reikia atkreipti dėmesį i tai, kad visos reikšmès $W$ užfiksuotos grindų lygyje. Toliau šis koeficientas mažinamas, t. y. komfortas gerinamas kokybiškai irengtomis sèdynemis vagonuose (priedas). Tokiu būdu pagerinus vagonų komforto sąlygas galima tikètis pritraukti i geležinkelị daugiau keleivių. Tai puikiai iliustruoja to paties EJ 575 traukinio eksploatacija Vilnius-Kaunas ruože. 4.31 pav. parodytas keleivių skaičius minètame ruože.

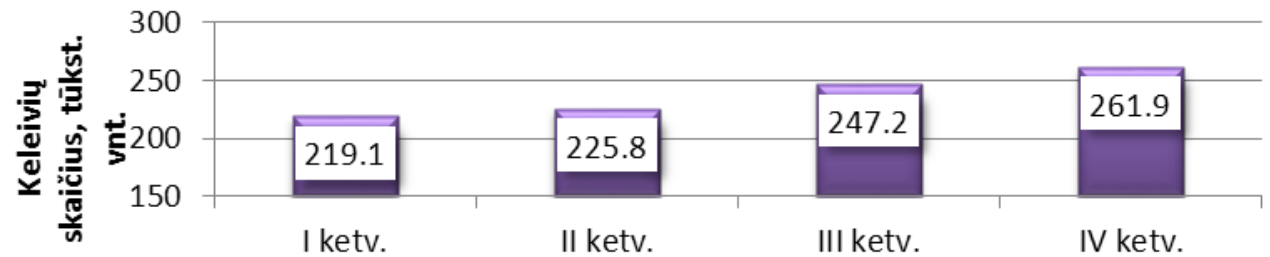

$2010 \mathrm{~m}$.

4.31 pav. Keleivių skaičiaus prieaugis ruože Vilnius-Kaunas per $2010 \mathrm{~m}$.

Fig. 4.31. Increase of passengers number for route Vilnius-Kaunas during 2010 
Šis grafikas puikiai iliustruoja faktą, kaip keleiviai „atradinejo“ komfortišką traukini. Visus metus keleivių nuolat daugejo. Lyginant su metų pradžia, jų padaugejo 19,5 proc. O tai rodo, kad, palyginti su praèjusiais metais, bendras 15 proc. padidejjimas turi tendenciją kilti.

\subsection{Darbe taikomų priemonių vežimo nuostolių mažinimo galimybès}

Šis tiriamasis darbas yra kompleksinis, jame siekiama parinkti tokias keleivių vežimo priemones, kad būtų galima pasiekti užsibrèžtą tikslą - parengti teorinius ir praktinius sprendinius, skirtus didinti pajamas bei mažinti keleivių vežimo geležinkeliais išlaidas, ivertinus technologinius poreikius konkretiems reisams bei dinamiškai kintančius keleivių srautus, bei gerinti keleivių komfortą. Trečiajame šio darbo skyriuje trimis pasirinktais maršrutais (Klaipeda-Vilnius, Vilnius-Šeštokai ir Vilnius-Turmantas), kuriais per metus nuvažiuojama daugiau kaip 40 proc. visų vagonų kilometrų $(3.9,3.10,3.12,3.13,3.15$ ir 3.16 pav.), parodyta, kad pritaikius traukinių parinkimo modeli (3.4), kai varijuojama ne tik sąstatų sudètimi (kai tai leidžia daryti keleivių skaičius), bet ir traukos rūšimis, galima pasiekti gerų ekonominių rezultatų. Pvz., reise Klaipėda-Vilnius, kai keleivių skaičius neviršija 100, galima sumažinti nuostolius apie 4 kartus, o reisui Vilnius-Turmantas panaudojus automotrisių derinius (nuo Pabradès vieną atkabinus), pajamos viršytų išlaidas apie $371 \mathrm{Lt}$ esant dabartiniam keleivių skaičiui.

Kaip rodo pastarujų dvejų metu stebejjimas, ỉsigijus naują šiuolaikinį traukinị, kuriame keleivių važiavimo sąlygos labai pagerèjo dèl jame įdiegtų pažangių technologijų (tolygi eiga, nèra triukšmo, puiki ergonomika, gera informacija, aptarnavimas ir pan.), keleivių skaičius padidejo 15 proc. 4.13 lenteleje pateikti anksčiau minètų ruožų vieno vagono kilometro ekonominiai rodikliai.

4.13 lentelès grafinè interpretacija pateikta 4.34 pav.

4.13 lentelè. Vieno vagono kilometro nuostoliai (pelnas) iki ir po optimizavimo Table 4.13. Profit (loss) per 1 carr./km before and after optimisation

\begin{tabular}{|l|c|c|c|}
\hline \multicolumn{1}{|c|}{ Maršrutai } & $\begin{array}{c}\text { Kursuojantis } \\
\text { sastatas, } \\
\text { Lt/vag. km }\end{array}$ & $\begin{array}{c}\text { Optimizuotas } \\
\text { sastatas, } \\
\text { Lt/vag. km }\end{array}$ & $\begin{array}{c}\text { Optimizuotas sastatas } \\
\text { ir keleivių padidèjimas } \\
15 \%, \mathrm{Lt} / \mathrm{vag} . \mathrm{km}\end{array}$ \\
\hline Klaipeda-Vilnius & $-6,77$ & $-0,15$ & $-0,07$ \\
\hline Vilnius-Š̌štokai & $-7,83$ & $-1,01$ & $-0,41$ \\
\hline Vilnius-Turmantas & $-6,34$ & 1,91 & 2,29 \\
\hline
\end{tabular}




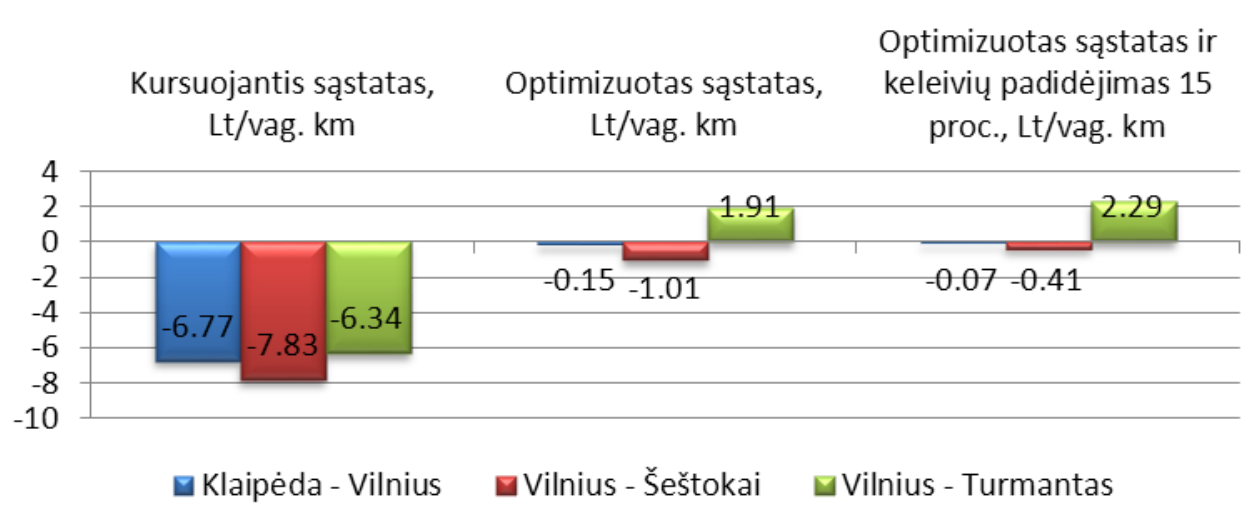

4.34 pav. Vieno vagono kilometro nuostoliai (pelnas) iki ir po optimizavimo

Fig. 4.34. One carriage/kilometre losses (profits) before and after the optimisation

Analizuojant 4.13 lentelès ir 4.34 pav. duomenis matyti, kad vien optimizavus reiso Klaipeda-Vilnius sąstatus ir trauka, vieno vagono $\mathrm{km}$ nuostoliai sumažèja iki 45 kartų, o padidejjus keleivių skaičiui 15 proc. - iki 100 kartų. Optimizavus reiso Vilnius-Turmantas sąstatus iš nuostolių $1 \mathrm{vag}$. $\mathrm{km}$ gaunama pelno. Jis dar padidejja, kai keleivių skaičius minètuose reisuose padidèja 15 proc.

Iš pateiktų rezultatų galima konstatuoti, kad sąstatų optimizavimas pagal keleivių skaičiu ir trauką bei komforto gerinimas keleiviniuose vagonuose yra efektyvios priemonès parenkant racionalias keleivių vežimo priemones ir mažinant nuostolius maršrutuose, o kai kuriuose - ir gaunant pelno.

\subsection{Ketvirtojo skyriaus išvados}

1. Pagrindinis veiksnys, mažinantis keleivių komforta, yra vagonų vibracijos. Mechaniniai virpesiai slopinami ivairiausiomis techninèmisergonominėmis priemonèmis, tačiau svarbiausias elementas šioje sistemoje yra važiuoklių pakabos. Čia lemiamas veiksnys yra tolygios eigos koeficientas, kuris glaudžiai siejasi su vibracijos dažniais, pagreičiais ir amplitudèmis.

2. Sudaryta tikslo funkcija leidžia apskaičiuoti dinaminius vagono rodiklius (vertikalius $K_{d v a}$ ir horizontalius $K_{d h a}$ ašidėžių rodiklius, minimalų stovumo $K_{s}^{\text {min }}$ koeficienta, centrinès pakabos vertikalų dinamini koeficientą $K_{d v a}^{\max }$ bei vertikaluji $A_{k v}^{\max }$ ir horizontaluji $A_{k h}^{\max }$ kèbulo pagreičius) esant bet kokiems leistiniesiems važiavimo greičiams. 
3. Nustatyta, kad skaičiuojant dinaminius procesus, būtina vertinti kontaktą tarp rato ir bejgio kaip nestabilu, t. y. rato atitrūkimą nuo bėgio.

4. Tyrimai parodè, kad nustatant optimalius važiuoklių pakabų parametrus, pagrindiniu rodikliu tikslo funkcijoje reikia laikyti stovumo koeficienta, nes šis parametras pirmasis riboja važiavimo greitị.

5. Optimizavus dinaminius parametrus, sudarytas pakabos atsparumo elementų skaičiavimo algoritmas.

6. Nurodytos pažangios ergonomikos priemonès, kurios turètų būti diegiamos naujuose keleiviniuose vagonuose (sèdynès, šildymas, paslaugu kompleksas) gerinant keleivių vežimo komfortą. 


\section{Bendrosios išvados}

Keleivių vežimo priemonių geležinkeliais kompleksinis tyrimas parodė, kad yra daugybè veiksnių kurie vienaip ar kitaip veikia sẻkminga ir efektyvų keleivių sektoriaus darbą geležinkelyje. Tačiau veiksniai, nagrinèjami šiame darbe, daro didžiausią itaką racionaliam keleivių vežimo priemonių parinkimui, kad galima būtų maksimaliai sumažinti iš šios veiklos patiriamus nuostolius, o kai kuriuose maršrutuose gauti ir pelno. Taigi apibendrinus gautus rezultatus galima padaryti tokias išvadas:

1. Pagrindinès priežastys, lemiančios nuostolius, atsirandančius vežant keleivius geležinkeliais, yra mažas keleivių skaičius, šiuolaikinių riedmenų trūkumas, prasta geležinkelių infrastruktūra, neracionalus riedmenų naudojimas atskiruose vietinio susisiekimo maršrutuose.

2. Pastaruoju metu keleivinių riedmenų parkas nèra optimaliai pritaikytas keleivių vežimui vietiniais maršrutais, naudojant lanksčią keleivių vežimo priemonių transformaciją pagal traukos rūšį ir kintamą keleivių skaičių.

3. Sudarytos regresijos lygtys pagal atskirus maršrutus, parodančios keleivių kaitos dinamika.

4. Sudarytas pajamų ir išlaidų matematinis modelis, įvertinantis visus galimus pajamų ir išlaidų veiksnius. 
5. Suformavus sąstatus pagal optimizuotą variantą reise Klaipėda-Vilnius, galima sumažinti nuostolius apie 4 kartus, o reise Vilnius-Turmantas gauti teigiamą rezultata, t. y. pasiekti, kad pajamos viršytų išlaidas.

6. Pagrindinis veiksnys, mažinantis keleivių komforta, yra vagonų vibracijos. Pagrindinis jų mažinimo veiksnys yra tolygios eigos koeficientas, kuris glaudžiai siejasi su vibracijos dažniais, pagreičiais ir amplitudėmis.

7. Sudaryta tikslo funkcija leidžia paskaičiuoti dinaminius vagono rodiklius (vertikalius ir horizontalius ašidèžių rodiklius, minimalų stovumo koeficientą, centrinès pakabos vertikalų dinamini koeficientą bei vertikalų ir horizontalų kèbulo pagreičius) esant bet kokiems leistiniesiems važiavimo greičiams.

8. Tyrimai parodè, kad nustatant optimalius važiuoklių pakabų parametrus, pagrindiniu rodikliu tikslo funkcijoje reikia laikyti stovumo koeficienta, nes šis parametras pirmasis riboja važiavimo greiti.

9. Nurodytos pažangios ergonomikos priemonès, kurios turètų būti diegiamos naujuose keleiviniuose vagonuose (sėdynès, šildymas, paslaugu kompleksas) gerinant keleivių vežimo komfortą.

10. Naujinant keleivini geležinkelių parką tikslinga issigyti greitai transformuojamas keleivių vežimo priemones (pvz., modulinius traukinius), kurios atitiktų keleivių vežimo koncepciją Lietuvos sąlygomis. 


\section{Literatūra ir šaltiniai}

Bao, J.; Xin, L.; Tang, Z.; Zang, X. 2009. Solving the train delay problem with the periodic train diagram, in Proceedings of the International Conference on Transportation Engineering 2009, 368-373.

Bažant, M.; Kavička, A. 2009. Artificial neural network as a support of platform track assignment within simulation models reflecting passenger raiway station, Proceedings of the Institution of Mechanical Engineers, Part F: Journal of Rail and Rapid Transit 223(5): 505-515.

Bestle, D.; Eberhard, P. 1996. Multi-criteria Multi-model Design Optimization, in D. Bestle, W.Schiehlen (Eds.). Optimization of Mechanical Systems. Dordrecht: Kluwer Academic Publishers, 863-876.

Bestle, D.; Eberhard, P. 1994. Automated approach for optimizing dynamic systems, International Series of Numerical Mathematics 115: 225-233.

Bestle, D.; Eberhard, P. 1992. Analyzing and optimizing multibody systems, Mechanics Based Design of Structures and Machines 20(1): 67-92.

Budai, G.; Maróti, G.; Dekker, R.; Huisman, D.; Kroon, L. 2010. Rescheduling in passenger railways: rolling stock rebalancing problem, Journal of Scheduling 13(3): 281-297. 
Butkevičius, J. 2009. The strategy of passenger transportation by national railway transport the implementation of public service obligations, Transport 24(2): 180-186.

Butkevičius, J. 2007. Development of passenger transportation by railroad from Lithuania to European states, Transport 22(2): 73-79.

Butkevičius, J.; Jarašūniene, A.; Jackiv, I. 2008. Comparison of passenger transportation by Lithuanian road and railway transport in regard to traffic safety, in Proceedings of the 12th International Conference ,"Transport Means - 2008“, 147-150.

Butkevicius, J. 2008. SWOT analysis of passenger and freight transportation by Lithuanian railway transport, in Proceedings of the 12th International Conference ,, Transport Means - 2008“, 96-98.

Celebi, D.; Bolat, B.; Bayraktar, D. 2009. Light rail passenger demand forecasting by artificial neural networks, in International Conference on Computers and Industrial Engineering (CIE), 239-243.

Čiočys, V.; Jasilionis, R. 1990. Matematinis programavimas. Vilnius: Mokslas. $302 \mathrm{p}$.

Dailydka, S.; Lingaitis, L. P.; Myamlin, D.; Prichodko, V. 2008a. Modelling the interaction between railway wheel and rail, Transport 23(3): 236-239.

Dailydka, S.; Lingaitis, L. P.; Myamlin, D.; Prichodko, V. 2008b. Mathematical model of spatial fluctuations of passenger wagon, Maintenance and Reliability 4(40): 4-8.

De Pater, A. D. 1961. The approximate determination of the outing movement of a railway vehicle by aid of the method of Krylov and Bogoliubov, Applied Scientific Research, Section A 10: 203-228.

Durdev, D. 2009. Legal regulation of the railway transport of passengers in EU, in Proceedings University of Novi Sad, Faculty of Law 43(1): 67-84.

Erikson, P.; Arora, J. S. 2002. A comparison of global optimization algorithms applied to a ride comfort optimization problem, Journal Structural and Multidisciplinary Optimization 24(2): 157-167.

Filina, V. N. 2008. Competitiveness problems of the national transportation system, Journal of Studies on Russian Economic Development 19(3): 248-261.

Hilmola, O. P. 2009. Global railway passenger transports - efficiency analysis from period of 1980-2004, International Journal of Logistics Economics and Globalisation 2(1): 23-39. 
Hu, Z.; Yan, Y.; Qiu, Z. 2008. Research on optimization model of making intercity passenger train operation plan and ticket price, in Proceedings of the International Conference on Information Management, Innovation Management and Industrial Engineering 45-48.

Jones, D. R.; Perttunen, C. D.; Stuckman, B. E. 1993. Lipschitzian optimization without the Lipschitz constant, Journal of Optimization Theory and Applications 79(1): 157-181.

Kalker, J. 1967. On the Rolling of Two Elastic Bodies in the Presence of Dry Friction: Doctoral Thesis Delft Technological University.

Kasturia, S.; Verma, A. 2010. Multiobjective transit passenger information system design using GIS, Journal of Urban Planning and Development 136(34): $34-41$.

Keršys, R.; Bazaras, Ž. 2001. Keleivinio vagono dinamika važiuojant izoliuotomis idubomis, Transportas 16(3): 93-99.

Li, K. P.; Gao, Z. Y.; Mao, B. H.; Cao, C. X. 2009. Optimizing Train Network Routing Using Deterministic Search, Journal of Networks and Spatial Economics (Infrastructure Modelingg and Computation) 9: 1-13.

Lietuvos Respublikos geležinkelių transporto kodeksas. 2004. Patvirtinta $2004 \mathrm{~m}$. balandžio 22 d. ịstatymu Nr. IX-2152.

Manoj, K. Jha; Schonfeld, P.; Sutapa, S. 2007. Optimizing Rail Transit Routes with Genetic Algorithms and Geographic Information System, Journal of Urban Planning and Development 133(3): 161-171.

Maskeliūnaitè, L.; Sivilevičius, H.; Podvezko, V. 2009. Research on the quality of passenger transportation by railway, Transport 24(2): 100-112.

Mechaniniai virpesiai ir smügiai. Vibracijos, veikiančios visq žmogaus kūna, poveikio ìvertinimas. 1 dalis. Bendrieji reikalavimai. LST ISO 2631-1. 2004. Vilnius: Lietuvos standartizacijos departamentas.

Pekarskas, V. 1996. Diferencialinis ir integralinis skaičiavimas. 1 dalis. Kaunas: Technologija. $388 \mathrm{p}$.

Sahin, B.; Yilmaz, H.; Ust, Y.; Guneri, A. F.; Gulsun, B. 2009. An approach for analysing transportation costs and a case study, European Journal of Operational Research 193(1): 1-11.

Savolainen, V. V.; Hilmola, O. P. 2009. The relative technical efficiency of European transportation systems concerning air transport and railways, International Journal of Business Performance Management 11(1/2): 19-42. 
Schraven, S. 2008. Passenger information systems for railway vehicles, International Trade Journal for rail Transport and Technology „,Der Eisenbahningenieur" 59(2): 22-24.

Shrivastava, P.; O'Mahony, M. 2009. Use of a hybrid algorithm for modeling coordinated feeder bus route network at suburban railway station, Journal of Transportation Engineering 135(1): 1-8.

Schiehlen, W. 1997. Multibody system dynamics, roots and perspectives, Journal Multibody System Dynamics 1(2): 149-188.

Snyman, J. A. 1983. An improved version of the original leap-frog dynamic method for unconstrained minimization: LFOP1(b), Journal Applied Mathematical Modelling 7(3): 216-218.

Tao, S.; Peng, Q.; Zha, W.; Jiang, C. 2007. Economic Evaluation Method of Passenger Train Plan, in Proceedings of the International Conference on Transportation Engineering 2007, 412-417.

Ustinovičius, L.; Zavadskas, E. K. 2004. Statybos investiciju efektyvumo sistemotechninis jvertinimas. Vilnius: Technika. $220 \mathrm{p}$.

Wang, H.; Cui Y.; Li, B. 2009. Related issues on train program of passenger special line, in Proceedings of the Second International Conference on Transportation Engineering 2007, 410-420.

Viešojo transporto efektyvaus panaudojimo vežant keleivius koncepcija. 2010. Vilnius: VI Socialinès ir ekonominès plètros centras. $62 \mathrm{p}$.

Zavadskas, E. K.; Kaklauskas, A. 1996. Pastatu sistemotechninis įvertinimas. Vilnius: Technika. 280 p.

Podvezko, V. 2005. Ekspertu iverčių suderinamumas, Technological and Economic Development of Economy 11(2): 101-107.

Zhang, Y.; Peng, Q. 2008. Study on passenger transfer network for integrated transportation, in Proceedings of the Eighth International Conference of Chinese Logistics and Transportation Professionals 5: 642-643.

Žilinskas, A. 2000. Matematinis programavimas. Kaunas: VDU leidykla. 227 p.

Блохин, Е. П.; Данович, В. Д.; Морозов, Н. И. 1986. Математическая модель пространственных колебаний четырехосного рельсового экипажа. Днепропетровск: Днепропетровский институт инженеров железнодорожного транспорта. $39 \mathrm{c}$.

Вериго, М. Ф.; Коган, А. Я. 1986. Взаимодействие пути и подвижного состава. Москва: Транспорт. 560 с. 
Вершинский, С. В.; Данилов, В. Н.; Хусидов, В. Д. 1991. Динамика вагона. Москва: Транспорт. 359 с.

Данович, В.Д. 1981. Пространственные колебания вагонов на инерционном пути: диссертация на соискание ученой степени кандидата технических наук. Днепропетровск. 465 с.

Ефимова, Г.Н. 2009. История создания и перспективы модернизаиии пассажирского вагона в России: автореферат диссертации на соискание ученой степени кандидата технических наук. Москва. 24 с.

Камаев, В.А. 1980. Оптимизаиия параметров ходовых частей железнодорожного подвижного состава. Москва: Машиностроение. 215 с Ковалев, Р. В. 2004. Разработка и реализачия эффективных методик компьютерного исследования динамики и оптимизачии параметров ходовых частей железнодорожных экипажей: автореферат диссертации на соискание ученой степени кандидата технических наук. Брянск. 27 с.

Козлов, М. П. 2010. Уточнения к расчету коэффициентов вертикальной динамики, Мир транспорта 1(29): 26-30. ISSN 1992-3252.

Коротенко, М. Л.; Данович, В. Д. 1973. Дифференциальные уравнения пространственных колебаний четырехосного вагона с учетом конечной жесткости кузова и инерционных свойств основания, Межвузовский сборник научных трудов «Проблемы механики наземного транспорта». Днепропетровск: ДИИТ, 199(25): 3-13.

Кузнецова, Н. В. 2007. Система маркетингового планирования объема пассажирских перевозок на примере природного железнодорожного транспорта: автореферат диссертации на соискание ученой степени кандидата экономических наук. Волгоград. 24 с.

Лазарян, В. А.; Длугач, Л. А.; Коротенко, М. Л. 1972. Устойчивость движения рельсовых экипажей. Киев: Наукова думка. 193 с.

Лазарян, В. А.; Коротенко, М. Л.; Данович, В. Д. 1966. Устойчивость движения железнодорожных экипажей с двойным рессорным подвешиванием: научные труды ДИИТ. Днепропетровск: ДИИТ, 45-51.

Лазарян, В. А. 1964. Динамика вагонов. Москва: Транспорт. 256 с.

Лисенко, О.А. 2006. Функциональные аспекты управления текущиими затратами пассажирских пригородных железнодорожных компаний: автореферат диссертации на соискание ученой степени кандидата экономических наук. Екатеринбург. 22 с. 
Манашкин, Л. А.; Мямлин, С. В.; Приходько, В. И. 2007. Гасители колебаний и амартизаторы ударов рельсовых экипажей (математические модели): монография. Днепропетровск: АРТ-ПРЕСС. 196 с.

Михайличенко, Г. С. 1986. Разработка методологии выбора структуры и параметров ходовой части мощных магистральных локомотивов и ее реализаџия на примере проектирования восьмиосных тепловозов: автореферат диссертации на соискание ученой степени кандидата технических наук. Брянск. 25 с.

Морозова, М. В. 2009. Обоснование системы управления затратами по пссажирским перевозкам на железнодорожном транспорте: автореферат диссертации на соискание ученой степени кандидата экономических наук. Москва. 23 с.

Мямлин, С. В.; Приходько, В. И.; Жижко, В. В. 2007. Совершенствование математической модели пространственных колебаний пассажирского вагона, Тезисы докладов 67 Международной научно-практической конференции «Проблемы и перспективы развития железнодорожного транспорта», 40-41.

Мямлин, С. В. 2003а. Математическая модель движения колеса по рельсовой нити, Сборник научных трудов Киевского университета экономики и технологии транспорта "Системы $u$ технологии транспорта». Киев: Киевский университет экономики и технологии транспорта, выпуск 1-2: 154-156.

Мямлин, С.В. 2003b. Улучшение динамических качеств рельсовых экипажей путем усовершенствования характеристик рессорного подвешивания: диссертация на соискание ученой степени кандидата технических наук. Днепропетровск. 455 с.

Мямлин, С.В. 2002а. Моделирование динамики рельсовых экипажей: монография. Днепропетровск: Новая идеология. 240 с.

Мямлин, С. В. 2002b. Влияние жесткости рессорного подвешивания на динамические показатели качества пассажирского вагона, Tpaнсnорm 10: $46-50$.

Николаев, В.А. 2003. Разработка методов аналитического конструирования квазиинвариантных систем рессорного подвешивания железнодорожных экипажей: автореферат диссертации на соискание ученой степени кандидата технических наук. Омск, 42 с.

Нормы для расчета и проектирования вагонов железных дорог МПС колеи 1520 мм (несамоходных). 1996. Москва: ГосНИИВ-ВНИИЖТ. 320 с. 
Оценка воздействия вибрации вагонов на пассажиров, Железные дороги мира 2000, 9: 36-38.

Полак, Б. Т. 1983. Введение в оптимизацию. Москва: Наука. 384 с.

Полак, Э. 1974. Числительные методы оптимизачии: единый подход. Москва: Мир. 369 с.

Реклейтис, Г.; Рейвиндран, А.; Рэгсдел, К. 1986. Оптимизация в технике. Том 1. Москва: Мир. 348 с.

Соболь, И. М. 1979. Численные методы Монте-Карло. Москва: Наука. $312 \mathrm{c}$.

Соколов, М. М.; Варава, В. И.; Левит, Г. М. 1985. Гасители колебаний железнодорожного подвижного состава. Москва: Транспорт. 216 с.

Сысоева, Е. А. 2008. Железнодорожная реформа в России и в странах запада: автореферат диссертации на соискание ученой степени кандидата экономических наук. Москва. 29 с.

Ушкалов, В. Ф.; Резников, Л. М.; Редько, С.Ф. 1982. Статистическая динамика рельсовых экипажей. Киев: Наукова думка. 359 с.

Шеффель, Г. 1974. Устойчивость при вилянии с боковым относом и способность подвижного состава вписываться в кривые, Железные дороги мира 12: 32-46. 



\section{Autoriaus publikaciju disertacijos tema sąrašas}

Straipsniai recenzuojamuose mokslo žurnaluose, itrauktuose ị ISI Web of Science sąrašą

Dailydka, S.; Lingaitis, L. P.; Myamlin, S.; Prichodko, V. 2008a. Modelling the interaction between railway wheel and rail, Transport 23(3): 236-239. ISSN 1648-4142 (ISI Web of Science).

Dailydka, S.; Lingaitis, L. P.; Myamlin, S.; Prichodko, V. 2008b. Mathematical model of spatial fluctuations of passenger wagon, Eksploatacja $i$ niezawodność = Maintenance and Reliability 4 (40): 4-8. ISSN 1507-2711 (ISI Web of Science).

Liudvinavičius, L.; Lingaitis, L. P.; Dailydka, S.; Jastremskas, V. 2009. The aspect of vector control using the asynchronous traction motor in locomotives, Transport 24(4): 318-324. ISSN 1648-4142 (ISI Web of Science).

Dailydka, S. 2010. Choosing railway vehicles for carrying for passengers, Transport 25(1): 11-16. ISSN 1648-4142 (ISI Web of Science).

Lingaitis, L. P.; Dailydka, S.; Myamlin, S.; Prichodko, V. 2008. Determination of conditions for search of optimal parameters of railway chassis suspensions, Transport Problems 3(1): 77-84. ISSN 1896-0596. 
Dailydka, S.; Lingaitis, L. P. 2009. Passenger transportation problems of the public limited liability company "Lietuvos geležinkeliai", Transport Problems 4(3): 45-50. ISSN 1896-0596.

\section{Straipsniai kituose leidiniuose}

Dailydka, S. 2009. Passenger transportation strategy of SC "Lithuanian Railways", in Proceedings of the 6th International Scientific Conference „TRANSBALTICA 2009“. Vilnius: Technika, 33-41. ISSN 2029-2376. 


\section{Priedai}

\section{P1. Naujų konstrukcijų keleivių sẻdynès}

Konkurencija tarp atskirų transporto rūšių vežant keleivius verčia įmonę nuolat rūpintis keleivių komfortu. Geležinkelių transporte šis veiksnys susijęs ir su riedmenų masès bei energijos mažinimu traukai.

Firmoms gamintojoms keliami didesni reikalavimai kuriant reikiamo klimato ir apšvietimo erdvius bei jaukius salonus, o interjero gamintojams - sukurti krèslus (sėdynes), kurie būtų patogūs keleiviams, mažintų nuovargi kelionès metu, mažintų vibracijas ir tolygios eigos koeficienta.

Natūralu, kad visuose traukiniuose galima irengti keleiviu poilsio zonas su minkštais baldais, atskirais stalais kaip eksperimentiniame Vokietijos geležinkelių traukinyje „Lirex“, tačiau norimą rezultatą galima pasiekti tobulinant krèslų konstrukcijas. 
Viena garsesnių imonių, gaminanti krèslus, yra prancūzų i̇monė „Antoin Loire“. Jos gamybos krèsluose sumontuoti lizdai, leidžiantys klausyti radijo laidų dešimčia kanalų, prijungti mobiluji telefoną ir nešiojamaji kompiuterị.

Vokiečiu imonė „Grammer" sukūrè visą gamą patobulintų krèslų greitaeigiams elektriniams traukiniams ICE3 (P1 pav.).

Juose sumontuotos atlenkiamosios sèdynès mažiems vaikams.

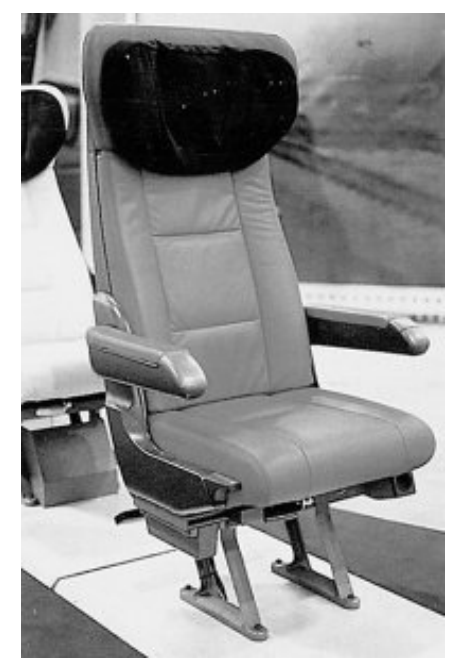

P1 pav. Imonès „Grammer" krèslas (sèdynè) elektriniame traukinyje ICE3

Fig. P1. "Grammer" seat in the electric train ICE3

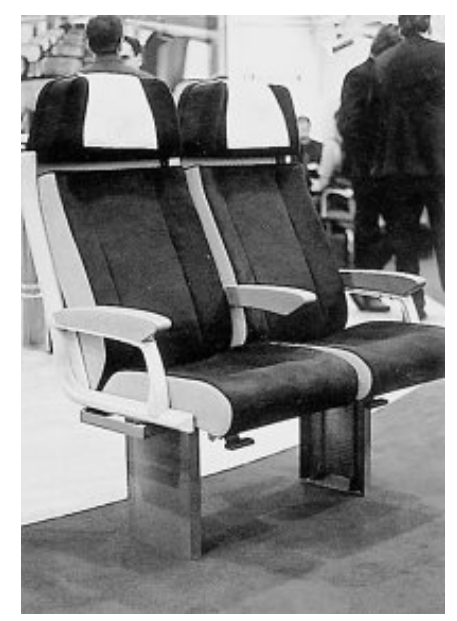

P2 pav. İmonès „Grammer“ 2000 tipo krèslas

Fig. P2. "Grammer" seat 2000 
Italų i̇monė „Clerprem“ gamina krèslus dviaukščiams TAF tipo elektriniams traukiniams. Šių krèslų dèl palengvinto rèmo iš aliuminio konstrukcijų (masė $6 \mathrm{~kg}$ ) masè tesiekia $15 \mathrm{~kg}$, o tai labai aktualu riedmenims, turintiems dideli skaičių sèdimujų vietų.

Vokiečių imonė „Vogel“" pateikè naują seriją „Pino“ tipo krèslų. Ji siūlo vartotojams visą savo produkcijos duomenų bazę, irašytą CD-ROM, kurioje vartotojas gali išsirinkti tinkamiausią konstrukciją bet kurios klasės vagonams.

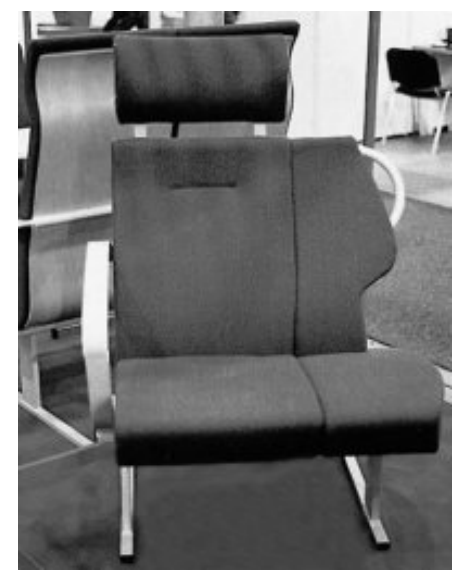

P3 pav. Imonès „Vogel“ krèslas priemiestiniams ir miesto traukiniams

Fig. P3. "Vogel" seat for commuter and city trains

Ispanų i̇monè „Fainsa“ siūlo krèslus dyzelinių traukinių pirmos klasės vagonams.

Čekų i̇monè „Borcad“ gamina trijų vietų transformuojamuosius krèslus (P4 pav.) miegamiesiems vagonams.

patogius Naujų konstrukcijų krèslus geležinkeliams taip pat gamina prancūzų imone் „Compin“, vokiečių imonè „Franz Kiel“, suomių - „Raccoon“.

Kitų šaliu patirtis rodo, kad mažinti eksploatacines išlaidas galima mažinant vagonų skaičių traukinyje vietų skaičiaus didinimo vagone sąskaita. Tam tikslui paprastai didinamas sèdimujų vietų skaičius kiekvienoje eilèje ir mažinamas krèslų išdèstymo žingsnis. Tačiau tokios priemonès mažina tiek keleivių komforta, tiek jų saugumą. Lèktuvuose elgiamasi kaip tik atvirkščiai - sėdynès platinamos, žingsnis didinamas.

Taigi minèti veiksniai rodo, kad keleivių salonų užimtumo optimizavimas yra gana sudètinga problema. Išsiaiškinta, kad keleivio laisvès pajauta salone daugiausia lemia kelionès komfortą. Komfortui gerinti būtina atsižvelgti ir į ergonomines priemones, tokias kaip sėdynių matmenys, atstumai tarp jų ir pan. 
a)

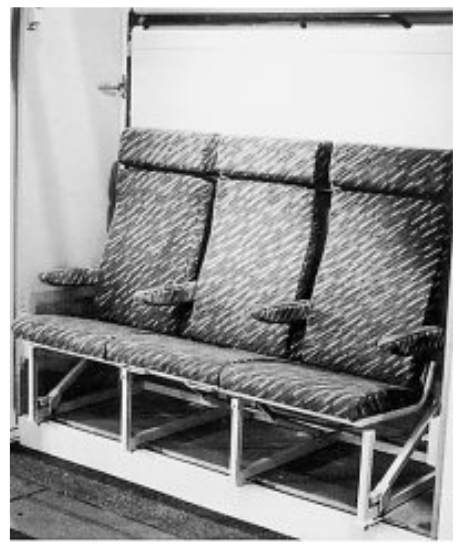

b)

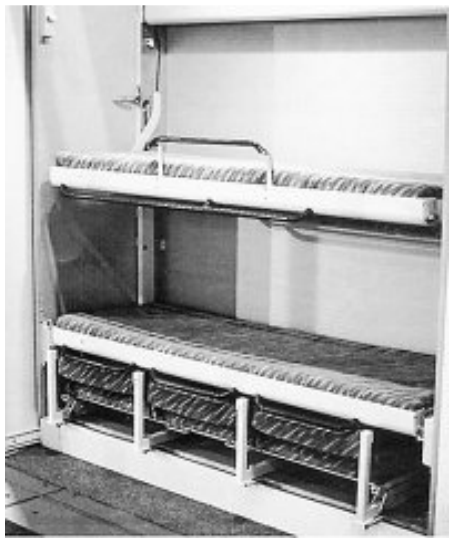

P4 pav. Imonès „Borcad“ transformuojamas krèslas: $a$-nuleistoje padètyje; $b$ - pakeltoje padètyje

Fig. P4. Company "Borcad" transformed chair: $\mathrm{a}$ - the lowered position; $\mathrm{b}$ - the upright position

Remiantis eksperimentinių tyrimų, atliktų „Shinkansen“ tinkle, rezultatais galima konstatuoti, kad triju vietų krèslo „Shinkansen“ tipo traukinio vagone vidurinè sèdynè, kurios paprastai keleiviai vengia, buvo palikta šiek tiek platesnè. Nors vidurinès alkūnių atramos pakeliamos, bet keleiviai jas palieka nuleistas, taip atsiribodami nuo greta sėdinčio keleivio.

Nustatant atstumus tarp krèslų eilių konstatuota, kad žingsnis tarp krèslų turi tam tikros įtakos, tačiau nèra vienintelis komforto veiksnys.

\section{P2. Vagonų šildymas}

Pastaruoju metu vagonų salonams šildyti dažniausiai naudojamos orinès ir konvekcinès sistemos. Kai oro kondicionavimo sistema šildoma įmontuotu kondicionieriuje kaitintuvu, šiluma kanalais tiekiama i vagonų patalpas. Tekant šilto oro srautui kanalais, kurių išoriniai paviršiai liečiasi su šaltu oru, prarandami dideli šilumos kiekiai. Jie tuo didesni, kuo toliau nuo šildomų patalpų yra centrinis šildymo itaisas.

Antrasis pastaruoju metu paplitęs šildymo metodas grindžiamas šildymo prietaisu decentralizavimu, pvz., po keleivių krèslais. Tačiau decentralizuota šildymo prietaisų sistema (išdèstymas) reikalauja daug vietos ir nemažų išlaidų kabeliams išvedžioti.

Kaip konvekcinio šildymo sistemą galima pateikti elektrinius radiatorius arba šildymo plokštes. Tokius prietaisus galima kabinti ant šoninių vagonų sienų, po sėdynėmis arba specialiose nišose. 
Standarto prEN 13129-3 9.1 ir 9.2 punktai reikalauja, kad temperatūrų skirtumas įvairiame vagonų aukštyje nuo grindų neviršytų nustatyto skirtumo. P5 pav. parodyta, kaip tokie taškai išdèstyti $L$ ilgio vagone. Šis reikalavimas turi užtikrinti tolygu šilumos pasiskirstymą vagono salone. Naudojant tradicines šildymo priemones, ši reikalavimą užtikrinti sunku.
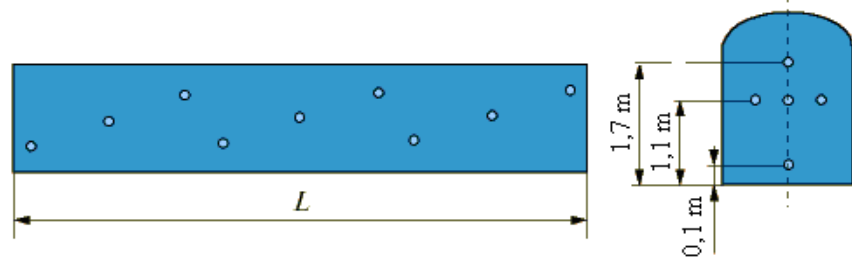

P5 pav. Temperatūros matavimo taškai vagone pagal standarta

Fig. P5 Temperature measurement points of the carriage according to standart

Plokštieji šildymo elementai. Šie šildymo elementai pastaruoju metu geriausiai tinka vienodai paskirstyti šilumą vagone ir padidinti keleivių komfortą. Be to, jie palyginti geriau apsaugoti nuo vandalizmo ir dirbant nekelia triukšmo.

Pagrindinis jų pranašumas - efektyvus šilumos spinduliavimas visu paviršiumi. Tolygiai šildant supančią keleivị erdvę, nesukuriami keleiviui nepatogūs oro srautai, kurie gali sukelti ir dulkių. Galimybè tolygiai šildyti grindis, lubas ir sienas leidžia vagone palaikyti 2-3 laipsniais žemesnę temperatūrą negu kitu būdu šildomuose vagonuose, keleiviui to nejuntant. Vokietijos standartai numato tokias temperatūras: grindų paviršiaus $-30{ }^{\circ} \mathrm{C}$, sienų, lubų ir pertvarų $-35^{\circ} \mathrm{C}$. Šildymo prietaisu parametrai turi būti skaičiuojami šioms temperatūroms.

Plokščiųjų šildytuvų konstrukcijos. Geležinkelio riedmenims geriausiai tinka silikoniniai ir plèveliniai kaitinimo elementai.

Silikoniniai elementai iš visų plokščiujuc elementų šiuo metu taikomi plačiausiai (pvz., mašinisto kabinos nišoje kojoms šildyti). Juose naudojami $\mathrm{NiCr}$ arba CuNi lydinio spirale, apvyniota ant plonos stiklo pluošto plokštelès. Ji irengiama tarp dviejų silikono sluoksnių, armuotu stiklo pluoštu kartu su šilumai laidžiu užpildu (P6 pav.).

Veikiant aukštai temperatūrai ir slègiui, vyksta vulkanizavimo procesas ir spiralè hermetiškai uždaroma tarp apsauginių sluoksnių. Gautas kaitinimo elementas pasižymi geru mechaniniu, elektriniu ir terminiu atsparumu, todèl ji galima naudoti sunkiomis geležinkelių riedmenų eksploatavimo sąlygomis.

Kadangi konstrukcijos elementai elastingi, kaitintuvams galima suteikti bet kokią formą pagal užsakovo pageidavimus. Tinkamai parinkta forma dar labiau padidina šildytuvų efektyvumą, tolygiai ir kryptingai spinduliuojant šilumą konkrečioje sumontuoto šildytuvo vietoje. 


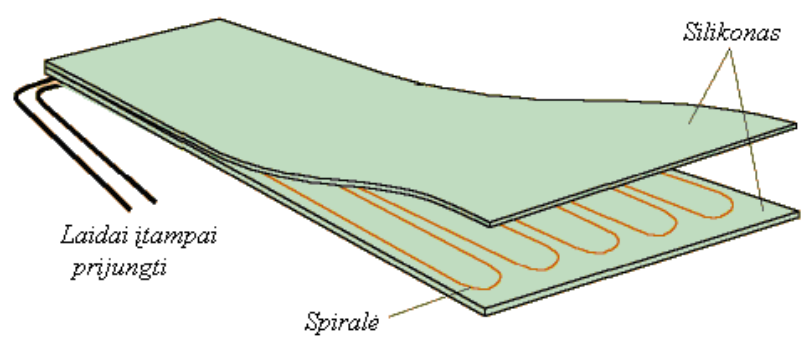

P6 pav. Silikoninio kaitintuvo elemento konstrukcija

Fig. P6. Silicone heater element design

Praktiškai tai reiškia, kad tokie šildymo elementai vulkanizavimo būdu gali būti sẻkmingai sujungti su konstrukcijomis, kurias reikia apšildyti, pvz., tambūrų laiptelių paviršiais. Vulkanizavimo metu elastinga gumos pavidalo polimerinės danga stipriai jungiasi su nerūdijančiuoju plienu, aliuminio lydiniais, spalvotaisiais metalais ir kt.

Silikoniniai elementai naudojami ilgai, tačiau juos pakeisti gana sudètinga, tam reikia skirti daug laiko ir lèšų.

Aukštos mechaninès silikoninių elementų charakteristikos (atsparumas gniuždymui ir tempimui) leidžia taikyti ịvairiausius jų tvirtinimo būdus: kabinti ant itemptų spyruokliu, kilpų kabliu, prispausti plokšte su varžtais. Kadangi srovės nedidelès, juos taip pat galima klijuoti prie metalo, stiklo, keramikos ir plastmasès. Priklausomai nuo poreikio, gali būti naudojamos ìvairaus galingumo spiralès.

Kaitintuvams reguliuoti reikalingi jutikliai ir reguliavimo elementai. Jais gali būti, pavyzdžiui, strypinis jutiklis, idètas i specialų lizdą ir sumontuotas termostate. Atsižvelgiant $i$ taikymo sriti, silikoninès masès kaitintuvai gali atitikti griežtus priešgaisrinès saugos reikalavimus.

Plèveliniai kaitintuvai. Plèveliniai kaitintuvai $0,6-0,8 \mathrm{~mm}$ storio, kurių lyginamoji masė $240-360 \mathrm{~g} / \mathrm{m}$ esant 400 arba $600 \mathrm{~mm}$ pločiui yra gera alternatyva silikoniniams kaitintuvams. Plèvelè apskaičiuota pakankamoms, nors ir nelabai aukštoms temperatūroms, todèl maksimali paviršiaus šiluminè apkrova apribota $0,17 \mathrm{~W} / \mathrm{m}^{2}$ dydžiu.

Plèvelini kaitintuvą sudaro stiklo audinys, kurio paviršius padengtas anglies ir grafito miltelių sluoksniu (P7 pav.). Maitinimo itampai ijungti naudojamos varinès alavuotos juostelès. Izoliacija gaminama iš laminato - aukštos kokybès kompozicinès poliesterinès-polietileninès plèvelès.

Pastaruoju metu šio tipo plokštieji elementai naudojami daugiausia namų grindims, luboms ir sienoms šildyti. Stacionariomis sąlygomis jų naudojimo laikas siekia iki 30 metų. Ar tinka jos geležinkelio riedmenims - dar reikalingi atitinkami tyrimai. Ypač reikètų patikrinti trijų plèveliu (kaitinimo ir dviejų izoliacinių) sujungimo ị vieną vienetą stiprumą geležinkelio sąlygomis, taip pat atsparumą ugniai. 


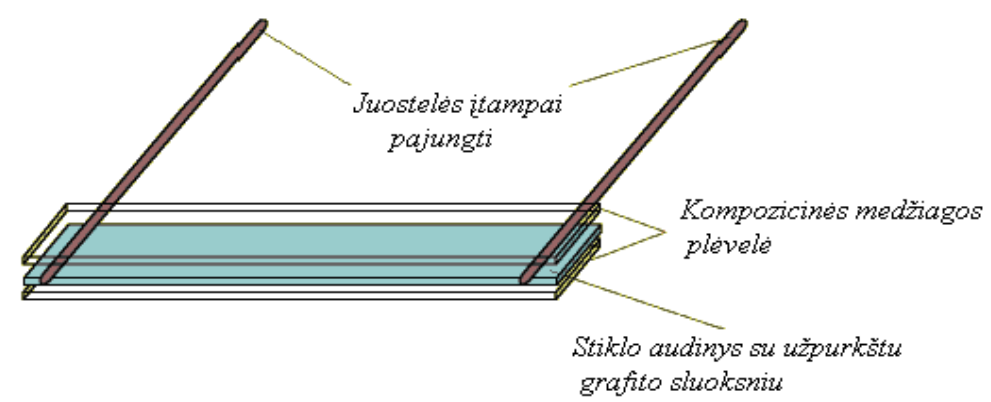

P7 pav. Plèvelinis kaitinimo elementas

Fig. P7. Filmy heater

Perspektyva. Plèvelinių kaitintuvų, siekiant naudoti juos geležinkelių transporte, tyrimai turi būti atlikti bandant juos priešgaisriniams reikalavimams, mechaniniam atsparumui, kartu vibracinèms ir smūginèms apkrovoms, taip pat eksploataciniam suderinamumui.

Šio tipo elementai, turintys mažą masę ir storị, didelį lankstumą bei mažai kainuojantys, atskleidžia naujų galimybių didinant komfortą keleiviniuose vagonuose, pavyzdžiui, apšildant tam tikras vietas tualetuose, irengiant aktyvią šilto oro kanalų izoliacija, pašildant sėdynes kai kuriose vagonų zonose. Tai labai perspektyvi medžiaga naudoti mašinisto kabinoje.

\section{P3. Maitinimo kultūra}

Gastronominès tradicijos ir valgymo stilius apibūdina visuomenès socialinio gyvenimo normas, išreiškia kiekvienos konkrečios šalies požiūrių skirtumus ir mentaliteta. Didejjantis gyventojų mobilumas taip pat daro didžiulę įtaką valgymo papročiams.

Pirmiesiems keliautojams geležinkeliais laiko praleidimas traukiniuose dažniausiai asocijavosi su laikraščiu, knygų skaitymu, o dar dažniau - su geru vynu ir delikatesais.

Amerikos ir Europos geležinkeliuose restorano vagonai pasirode XIX a. septintajame dešimtmetyje. Šveicarijoje tokie vagonai buvo brangių tarptautinių traukinių kategorijos „Liuks“ atributas. Taip bent buvo iki XX a. pradžios. 1903 m. ikurta šveicarų restorano vagonų įmonẻ SSG, kuri veikia ir dabar, nuomoja vagonus ir aptarnaujantiji personalą.

Pirmojo pasaulinio karo metu restorano vagonų statusas smarkiai sumenko. Tai lèmè didžiulè infliacija, maisto produktų trūkumas, nutrūkę turistų srautai. Tačiau jau 1920 m., nepaisant ekonominès krizès, ši veiklos rūšis atgimė. Piką ji pasiekè Antrojo pasaulinio karo laikotarpiu (nepaisant maisto produktų limita- 
vimo), nes sumažejjus automobilių transporto (ypač privataus) parkui, daugelis žmonių persèdo i geležinkelių transportą.

Tačiau didelè plačios visuomenès dalis neturejjo tiek lèšų kad galètų naudotis restorano vagonų paslaugomis. Keleivių aptarnavimo rūšys, atitinkančios keleivių, vykstančių su savais sumuštiniais, poreikius pasirode tik apie $1951 \mathrm{~m}$. Tuomet oro transporto pavyzdžiu vagonuose užkandžiams ir karštiems gérimams pristatyti i keleivių vietas buvo pradèti naudoti išvežiojamieji vežimèliai. Ši sistema iš pat pradžių turèjo dideli pasisekimą.

Maitinimo organizavimas transporto sektoriuje yra potencialiai pelninga veiklos rūšis, tačiau kelia griežtus reikalavimus operatoriams struktūrinès decentralizacijos sąlygomis, susijusiomis su logistikos išlaidomis. Didelę itaką turi ir tas faktas, kad keleivių norai maisto asortimentui nuolat kinta.

1980 m. pabaigoje šią veiklos rūši Šveicarijoje ištiko krizè. SSG įmonè pradèjo dirbti nuostolingai, todèl buvo būtina ieškoti alternatyvos.

Buvo pradeti nagrinèti du variantai: atsisakyti tradicinès keleivių aptarnavimo formos per restorano vagonus arba paskliauti konkurencija tarp operatorių. SSB pasirinko antraji varianta, nes rinkoje pasirodè dvi naujos įmonès - „MiniBuffet“" (naudojanti išvežiojamuosius vežimèlius) ir „McDonalds Schweiz“. Šis variantas turèjo pasisekimą iki tol, kol atsirado išvežiojamujų vežimèlių vagonuose alternatyva - išplèstas parduotuviu tinklas stotyse. Keleiviai įsigydavo proviziją prieš sėsdami i traukinị. Prekyba iš vežimèliu susidūrè su daugeliu problemų, tarp jų ir apyvartos sumažejjimu.

1997 m. pradejjus eksploatuoti greitaeigi dviaukšti traukini IC-2000 reikèjo realizuoti ir naują maitinimo koncepciją. Buvo suprojektuoti ir pagaminti bistro vagonai, labiau atitinkantys keleiviu poreikius ir trumpinantys kelionés laiką. Tuo pačiu keliu pasuko ir Vokietijos bei Prancūzijos geležinkeliai.

Visuose traukiniuose senieji vežimèliai „Minibar“ buvo pakeisti vežimèliais „Railbar“. Šie vežimèliai turi įmontuotą konteinerini šaldytuvą, kuris geriausiai tinka pateikti ịvairiausią maistą keleiviui trumpoje kelioneje. Keleiviui siūloma 60 patiekalų, vyno, šalto alaus ir kitu gèrimų. Karštas maistas ruošiamas kiekvieną dieną artimiausioje centralizuotoje maisto gaminimo bazejje. Kokybišku produktų asortimentas atnaujinamas kas ménesị. Pirmajame bistro vagono aukšte irrengiamas baras, kuriame leidžiama rūkyti, užkandžiauti, o antrajame keleiviai gauna šilto maisto, ten puikus klimatas ir kultūringas aptarnavimas. Bistro vagono koncepcija - tai pavyzdys, kaip ịvairiapusis aptarnavimas leido efektyviai pritraukti keleivius iš automobilių i geležinkelių transportą. Be to, firmos tiki, kad esant aukštam aptarnavimo lygiui ir kokybiškiems produktams, ši veiklos rūšis gali būti pelninga.

Ši trumpa maitinimo kultūros apžvalga geležinkelių transporte rodo, kad užsienio šalių įmonès, skirdamos didelį dèmesị maitinimui, stengiasi visais būdais pritraukti keleivius, laiku juos pamaitindami, ir pagrindini pelną gauna ne iš 
parduotos provizijos, o iš didesnio skaičiaus nupirktų bilietų. Mūsų šalyje, esant palyginti nedideliems atstumams, norint pritraukti kuo daugiau keleivių, maitinimas turi būti tinkamai organizuotas ir turi atitikti minimaliausius klientu poreikius, kad ir neilgos kelionès metu. Ypač gerai ši aptarnavimo rūšis privalo būti organizuota persèdimo punktuose, kuriuose kito traukinio tenka laukti valandą ir daugiau. Pagal autoriaus parengtas technines sąlygas buvo pradèti modernizuoti keleiviniai restorano vagonai. Juose irengti šiuolaikiniai interjerai, patogios sèdynès, sandarūs langai, vakuuminiai tualetai, informacinès sistemos, modernios virtuvès, malonus apšvietimas (P8 pav.).

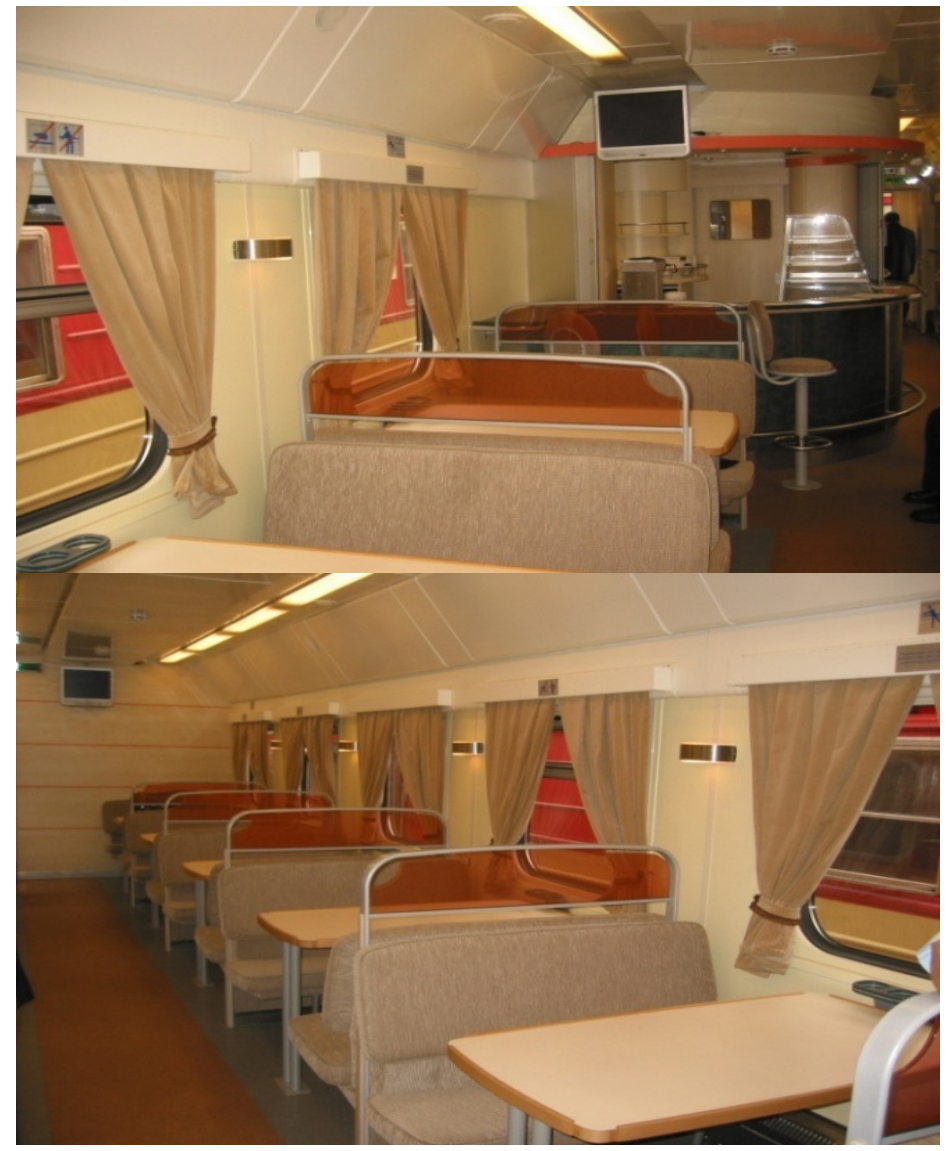

P8 pav. Modernizuotas restorano vagonas

Fig. P8. Improved dining carriage

Šie vagonai kursuoja traukiniuose i Maskvą, Sankt Peterburgą, taip pat ir maršrutu Vilnius-Klaipèda. 


\section{P4. Paslaugų kompleksas}

Vežant keleivius socialinis ir kultūrinis aptarnavimas - tai organizuota aptarnavimo sistema, leidžianti keleiviui pasirinkti optimalų (ekonomiškai naudinga) teikiamų prekių ir paslaugų variantą sukuriant komforto sąlygas kelionejje.

Tam tikslui būtina atitinkama technine iranga ir infrastruktūra. Be komfortiškų vagonų ir atitinkamo techninio bei technologinio aptarnavimo neįmanomas konkurencinga santykis su kitomis transporto rūšimis.

Keleiviu vežimo aptarnavimas traktuojamas ne kaip veikla, didinanti pagrindinès paslaugos - keleivių vežimo - pajamas, o kaip aptarnavimo sistema, leidžianti pagerinti kelionès sąlygas geležinkelių transportu ir didinti jo konkurencingumą transporto rinkoje. Aptarnavimui keliami tam tikri reikalavimai, $\mathfrak{i}$ kuriuos turi atsižvelgti keleivių vežimo įmonès:

1. Būtina paslaugų komplekso pasiūla ir vykdymas. Keleiviai turi būti informuojami apie kelionès metu teikiamas paslaugas.

2. Keleiviui nebūtina naudotis teikiamomis paslaugomis. Keleivių vežimo imonès ir jų struktūros neturi reikalauti iš kliento pirkti jų paslaugas.

3. Elastingumas. Aptarnavimo paslaugos turi būti teikiamos nuo vienetiniu arba minimaliai būtinų iki maksimalių (kompleksinių), kurias pasirenka pats keleivis.

4. Patogumas. Paslaugas reikia suteikti toje vietoje, tokiu laiku ir tokia forma, kurie tenkina keleivio norus.

5. Techninis adekvatumas. Techninis riedmenų lygis ir jų iranga (nuimamas ir nenuimamas inventorius bei irenginiai) turi atitikti aptarnavimo technologiją. Antraip nebus pasiekta aptarnavimo kokybè.

6. Informaciné grąža. Keleivių vežimo įmonè turi teikti informaciją apie kleivių atsiliepimus ir pageidavimus dèl aptarnavimo sistemos funkcionavimo.

7. Protinga kainų politika. Ji gali padaryti didelę itaką prekių ir paslaugų vartojimui.

8. Aptarnavimo garantija. Būtina elgtis taip, kad keleivis niekuomet nepakliūtų i padèti ,apsitarnauk pats“.

Transporto aptarnavimo paslaugų gausa reikalauja nuolatinès mokslinès ir inžinerinès minties pagalbos, tobulinant esamus ir kuriant naujus metodus, sistemas, technologijas bei techniką kleiviams vežti. Tai leistų pritraukti daugiau keleivių iš kitų transporto rūšių i geležinkelio transporta, pakelti keleivių vežimą geležinkeliais i aukštesni lygi, lyginant su konkurentais, bei padidinti pajamų ir išlaidų santyki. 


\section{P5. Priemonių parinkimo modelio sprendinių paieškos MATLAB programos pavyzdys}

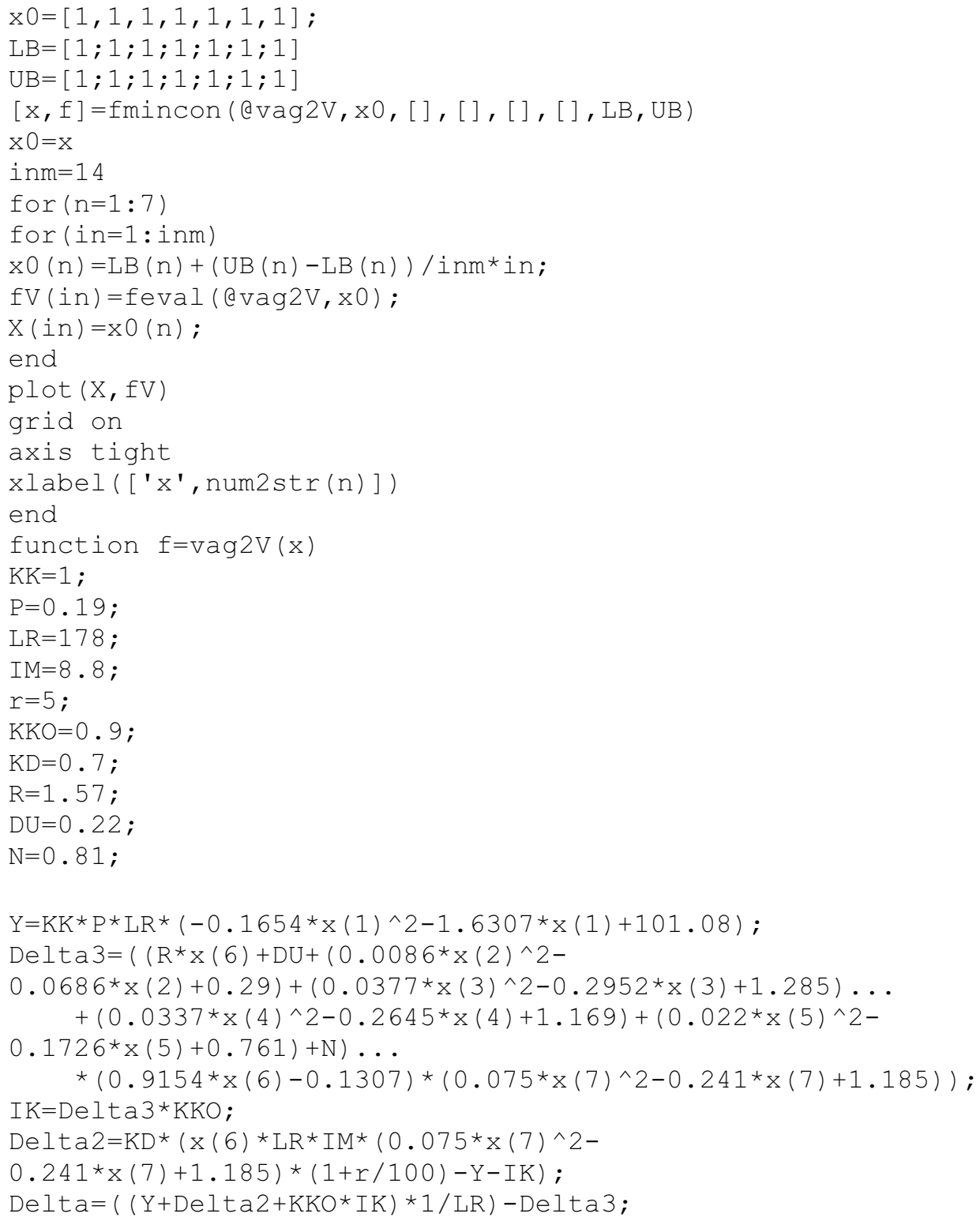




\section{P6. Ašidėžių pakabos parametrų patikrinamujų rezultatų skaičiavimai}

L1 lentelè. I varianto dinaminiai rodikliai

Table L1. I version of dynamic indicators

\begin{tabular}{|c|c|c|c|c|c|c|c|}
\hline \multirow{15}{*}{ 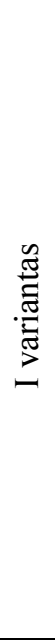 } & $v, \mathrm{~km} / \mathrm{h}$ & $K_{d v a}$ & $K_{d h a}$ & $K_{s}$ & $K_{d v c}$ & $W_{v}$ & $W_{h}$ \\
\hline & 40 & 0,056 & 0,065 & 5 & 0,034 & 1,831 & 1,497 \\
\hline & 60 & 0,124 & 0,063 & 5 & 0,054 & 2,226 & 1,691 \\
\hline & 80 & 0,126 & 0,069 & 5 & 0,044 & 2,172 & 1,759 \\
\hline & 100 & 0,15 & 0,067 & 5 & 0,044 & 2,262 & 1,884 \\
\hline & 120 & 0,156 & 0,086 & 5 & 0,046 & 2,412 & 2,068 \\
\hline & 140 & 0,191 & 0,112 & 4,836 & 0,055 & 2,537 & 2,198 \\
\hline & 160 & 0,234 & 0,119 & 4,641 & 0,069 & 2,573 & 2,313 \\
\hline & 180 & 0,262 & 0,122 & 4,429 & 0,065 & 2,566 & 2,487 \\
\hline & 200 & 0,308 & 0,119 & 4,484 & 0,078 & 2,785 & 2,565 \\
\hline & 220 & 0,317 & 0,124 & 4,446 & 0,073 & 2,861 & 2,625 \\
\hline & 240 & 0,321 & 0,139 & 3,826 & 0,082 & 2,883 & 2,713 \\
\hline & 260 & 0,306 & 0,156 & 2,814 & 0,098 & 2,974 & 2,772 \\
\hline & 280 & 0,279 & 0,17 & 2,583 & 0,098 & 2,977 & 2,848 \\
\hline & 300 & 0,266 & 0,172 & 2,777 & 0,082 & 2,912 & 2,896 \\
\hline
\end{tabular}

L2 lentelè. II varianto dinaminiai rodikliai

Table L2. II version of dynamic indicators

\begin{tabular}{|c|c|c|c|c|c|c|c|}
\hline \multirow{15}{*}{ 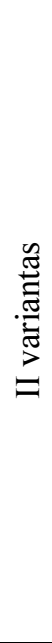 } & $v, \mathrm{~km} / \mathrm{h}$ & $K_{d v a}$ & $K_{\text {dha }}$ & $K_{s}$ & $K_{d v c}$ & $W_{v}$ & $W_{h}$ \\
\hline & 40 & 0,054 & 0,068 & 5 & 0,033 & 1,824 & 1,518 \\
\hline & 60 & 0,118 & 0,058 & 5 & 0,052 & 2,198 & 1,701 \\
\hline & 80 & 0,121 & 0,072 & 5 & 0,041 & 2,156 & 1,761 \\
\hline & 100 & 0,141 & 0,069 & 5 & 0,042 & 2,247 & 1,903 \\
\hline & 120 & 0,146 & 0,087 & 5 & 0,044 & 2,383 & 2,068 \\
\hline & 140 & 0,188 & 0,11 & 5 & 0,055 & 2,507 & 2,18 \\
\hline & 160 & 0,228 & 0,116 & 4,939 & 0,066 & 2,546 & 2,275 \\
\hline & 180 & 0,261 & 0,115 & 5 & 0,065 & 2,565 & 2,436 \\
\hline & 200 & 0,301 & 0,113 & 4,88 & 0,073 & 2,766 & 2,543 \\
\hline & 220 & 0,315 & 0,118 & 4,85 & 0,071 & 2,837 & 2,614 \\
\hline & 240 & 0,315 & 0,119 & 4,583 & 0,085 & 2,869 & 2,706 \\
\hline & 260 & 0,295 & 0,129 & 4,013 & 0,098 & 2,948 & 2,78 \\
\hline & 280 & 0,287 & 0,15 & 3,819 & 0,094 & 2,944 & 2,82 \\
\hline & 300 & 0,269 & 0,146 & 3,374 & 0,078 & 2,883 & 2,892 \\
\hline
\end{tabular}


L3 lentelè. III varianto dinaminiai rodikliai

Table L3. III version of dynamic indicators

\begin{tabular}{|c|c|c|c|c|c|c|c|}
\hline \multirow{15}{*}{ 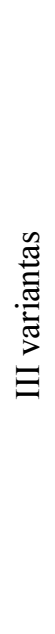 } & $v, \mathrm{~km} / \mathrm{h}$ & $K_{d v a}$ & $K_{\text {dha }}$ & $K_{s}$ & $K_{d v c}$ & $W_{v}$ & $W_{h}$ \\
\hline & 40 & 0,074 & 0,055 & 5 & 0,029 & 1,849 & 1,451 \\
\hline & 60 & 0,143 & 0,064 & 5 & 0,051 & 2,267 & 1,646 \\
\hline & 80 & 0,205 & 0,065 & 5 & 0,044 & 2,252 & 1,744 \\
\hline & 100 & 0,203 & 0,067 & 5 & 0,054 & 2,319 & 1,901 \\
\hline & 120 & 0,226 & 0,081 & 5 & 0,051 & 2,454 & 2,064 \\
\hline & 140 & 0,243 & 0,104 & 4,797 & 0,066 & 2,549 & 2,216 \\
\hline & 160 & 0,293 & 0,117 & 4,186 & 0,079 & 2,601 & 2,387 \\
\hline & 180 & 0,317 & 0,129 & 3,85 & 0,076 & 2,583 & 2,538 \\
\hline & 200 & 0,351 & 0,144 & 3,568 & 0,09 & 2,767 & 2,622 \\
\hline & 220 & 0,379 & 0,159 & 3,343 & 0,076 & 2,899 & 2,668 \\
\hline & 240 & 0,393 & 0,174 & 2,942 & 0,089 & 2,908 & 2,748 \\
\hline & 260 & 0,389 & 0,203 & 2,577 & 0,103 & 2,986 & 2,829 \\
\hline & 280 & 0,367 & 0,24 & 2,183 & 0,099 & 3,034 & 2,893 \\
\hline & 300 & 0,345 & 0,237 & 2,121 & 0,091 & 2,988 & 2,937 \\
\hline
\end{tabular}

L4 lentelè. IV varianto dinaminiai rodikliai

Table L4. IV version of dynamic indicators

\begin{tabular}{|c|c|c|c|c|c|c|c|}
\hline \multirow{15}{*}{ 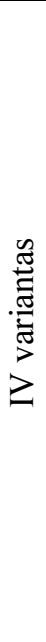 } & $v, \mathrm{~km} / \mathrm{h}$ & $K_{d v a}$ & $K_{d h a}$ & $K_{s}$ & $K_{d v c}$ & $W_{v}$ & $W_{h}$ \\
\hline & 40 & 0,031 & 0,062 & 5 & 0,024 & 1,711 & 1,415 \\
\hline & 60 & 0,056 & 0,085 & 5 & 0,028 & 1,853 & 1,607 \\
\hline & 80 & 0,08 & 0,071 & 5 & 0,027 & 1,917 & 1,692 \\
\hline & 100 & 0,107 & 0,084 & 5 & 0,032 & 2,046 & 1,801 \\
\hline & 120 & 0,144 & 0,089 & 5 & 0,047 & 2,189 & 1,929 \\
\hline & 140 & 0,189 & 0,111 & 4,722 & 0,047 & 2,199 & 2,051 \\
\hline & 160 & 0,263 & 0,135 & 3,872 & 0,055 & 2,274 & 2,2 \\
\hline & 180 & 0,294 & 0,149 & 3,354 & 0,051 & 2,412 & 2,333 \\
\hline & 200 & 0,336 & 0,155 & 3,287 & 0,062 & 2,482 & 2,424 \\
\hline & 220 & 0,358 & 0,166 & 3,072 & 0,067 & 2,54 & 2,486 \\
\hline & 240 & 0,369 & 0,181 & 2,835 & 0,058 & 2,57 & 2,557 \\
\hline & 260 & 0,352 & 0,201 & 2,596 & 0,051 & 2,516 & 2,628 \\
\hline & 280 & 0,352 & 0,216 & 2,448 & 0,052 & 2,5 & 2,713 \\
\hline & 300 & 0,345 & 0,23 & 2,257 & 0,053 & 2,484 & 2,764 \\
\hline
\end{tabular}


L5 lentelè. $V$ varianto dinaminiai rodikliai

Table L5. V version of dynamic indicators

\begin{tabular}{|c|c|c|c|c|c|c|c|}
\hline \multirow{15}{*}{ 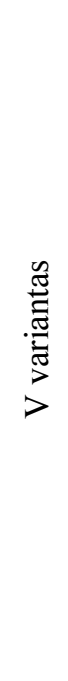 } & $v, \mathrm{~km} / \mathrm{h}$ & $K_{d v a}$ & $K_{d h a}$ & $K_{s}$ & $K_{d v c}$ & $W_{v}$ & $W_{h}$ \\
\hline & 40 & 0,05 & 0,076 & 5 & 0,031 & 1,818 & 1,531 \\
\hline & 60 & 0,108 & 0,065 & 5 & 0,049 & 2,189 & 1,712 \\
\hline & 80 & 0,111 & 0,078 & 5 & 0,042 & 2,141 & 1,773 \\
\hline & 100 & 0,134 & 0,077 & 5 & 0,04 & 2,238 & 1,925 \\
\hline & 120 & 0,143 & 0,097 & 5 & 0,046 & 2,39 & 2,102 \\
\hline & 140 & 0,183 & 0,124 & 4,863 & 0,055 & 2,519 & 2,205 \\
\hline & 160 & 0,226 & 0,126 & 4,617 & 0,068 & 2,541 & 2,301 \\
\hline & 180 & 0,261 & 0,12 & 4,542 & 0,067 & 2,558 & 2,441 \\
\hline & 200 & 0,298 & 0,114 & 4,662 & 0,074 & 2,775 & 2,562 \\
\hline & 220 & 0,317 & 0,117 & 4,493 & 0,071 & 2,833 & 2,625 \\
\hline & 240 & 0,313 & 0,12 & 4,47 & 0,085 & 2,861 & 2,702 \\
\hline & 260 & 0,293 & 0,134 & 4,157 & 0,094 & 2,945 & 2,737 \\
\hline & 280 & 0,28 & 0,135 & 4,084 & 0,088 & 2,931 & 2,799 \\
\hline & 300 & 0,279 & 0,196 & 3,598 & 0,073 & 2,864 & 2,846 \\
\hline
\end{tabular}

L6 lentelè. VI varianto dinaminiai rodikliai

Table L6. VI version of dynamic indicators

\begin{tabular}{|c|c|c|c|c|c|c|c|}
\hline \multirow{15}{*}{ 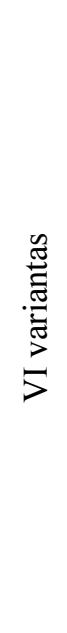 } & $v, \mathrm{~km} / \mathrm{h}$ & $K_{d v a}$ & $K_{d h a}$ & $K_{s}$ & $K_{d v c}$ & $W_{v}$ & $W_{h}$ \\
\hline & 40 & 0,073 & 0,056 & 5 & 0,03 & 1,843 & 1,467 \\
\hline & 60 & 0,138 & 0,056 & 5 & 0,052 & 2,255 & 1,653 \\
\hline & 80 & 0,186 & 0,066 & 5 & 0,043 & 2,233 & 1,75 \\
\hline & 100 & 0,193 & 0,064 & 5 & 0,049 & 2,305 & 1,888 \\
\hline & 120 & 0,213 & 0,081 & 5 & 0,051 & 2,434 & 2,045 \\
\hline & 140 & 0,238 & 0,102 & 4,897 & 0,065 & 2,532 & 2,192 \\
\hline & 160 & 0,284 & 0,115 & 4,394 & 0,076 & 2,586 & 2,347 \\
\hline & 180 & 0,308 & 0,129 & 4,16 & 0,076 & 2,582 & 2,514 \\
\hline & 200 & 0,344 & 0,143 & 3,894 & 0,086 & 2,762 & 2,588 \\
\hline & 220 & 0,369 & 0,15 & 3,655 & 0,074 & 2,887 & 2,649 \\
\hline & 240 & 0,378 & 0,161 & 3,057 & 0,089 & 2,9 & 2,731 \\
\hline & 260 & 0,371 & 0,173 & 2,751 & 0,101 & 2,978 & 2,802 \\
\hline & 280 & 0,346 & 0,188 & 2,67 & 0,101 & 3,018 & 2,874 \\
\hline & 300 & 0,33 & 0,203 & 2,504 & 0,09 & 2,976 & 2,925 \\
\hline
\end{tabular}


L7 lentelè. VII varianto dinaminiai rodikliai

Table L7. VII version of dynamic indicators

\begin{tabular}{|c|c|c|c|c|c|c|c|}
\hline \multirow{15}{*}{ 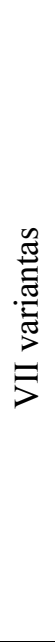 } & $v, \mathrm{~km} / \mathrm{h}$ & $K_{d v a}$ & $K_{d h a}$ & $K_{s}$ & $K_{d v c}$ & $W_{v}$ & $W_{h}$ \\
\hline & 40 & 0,072 & 0,064 & 5 & 0,029 & 1,855 & 1,492 \\
\hline & 60 & 0,152 & 0,096 & 5 & 0,051 & 2,276 & 1,734 \\
\hline & 80 & 0,208 & 0,077 & 5 & 0,045 & 2,26 & 1,838 \\
\hline & 100 & 0,202 & 0,095 & 5 & 0,051 & 2,323 & 1,965 \\
\hline & 120 & 0,22 & 0,095 & 5 & 0,051 & 2,454 & 2,12 \\
\hline & 140 & 0,234 & 0,118 & 4,344 & 0,066 & 2,547 & 2,295 \\
\hline & 160 & 0,28 & 0,149 & 3,505 & 0,079 & 2,602 & 2,463 \\
\hline & 180 & 0,299 & 0,163 & 3,32 & 0,076 & 2,582 & 2,576 \\
\hline & 200 & 0,335 & 0,17 & 3,348 & 0,089 & 2,769 & 2,672 \\
\hline & 220 & 0,373 & 0,164 & 3,493 & 0,074 & 2,895 & 2,678 \\
\hline & 240 & 0,389 & 0,169 & 3,396 & 0,088 & 2,903 & 2,757 \\
\hline & 260 & 0,384 & 0,179 & 3,1 & 0,101 & 2,989 & 2,795 \\
\hline & 280 & 0,361 & 0,187 & 2,722 & 0,102 & 3,033 & 2,884 \\
\hline & 300 & 0,342 & 0,196 & 2,807 & 0,092 & 2,988 & 2,922 \\
\hline
\end{tabular}

L8 lentelè. VIII varianto dinaminiai rodikliai

Table L8. VIII version of dynamic indicators

\begin{tabular}{|c|c|c|c|c|c|c|c|}
\hline \multirow{15}{*}{ 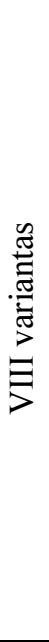 } & $v, \mathrm{~km} / \mathrm{h}$ & $K_{d v a}$ & $K_{\text {dha }}$ & $K_{s}$ & $K_{d v c}$ & $W_{v}$ & $W_{h}$ \\
\hline & 40 & 0,068 & 0,059 & 5 & 0,029 & 1,84 & 1,481 \\
\hline & 60 & 0,136 & 0,058 & 5 & 0,053 & 2,254 & 1,655 \\
\hline & 80 & 0,174 & 0,066 & 5 & 0,043 & 2,216 & 1,739 \\
\hline & 100 & 0,184 & 0,062 & 5 & 0,05 & 2,296 & 1,886 \\
\hline & 120 & 0,203 & 0,082 & 5 & 0,049 & 2,436 & 2,059 \\
\hline & 140 & 0,228 & 0,099 & 5 & 0,064 & 2,541 & 2,208 \\
\hline & 160 & 0,274 & 0,109 & 4,618 & 0,076 & 2,593 & 2,338 \\
\hline & 180 & 0,304 & 0,114 & 4,54 & 0,073 & 2,573 & 2,513 \\
\hline & 200 & 0,345 & 0,122 & 4,434 & 0,086 & 2,767 & 2,591 \\
\hline & 220 & 0,371 & 0,13 & 3,976 & 0,073 & 2,889 & 2,641 \\
\hline & 240 & 0,371 & 0,142 & 3,469 & 0,087 & 2,895 & 2,725 \\
\hline & 260 & 0,366 & 0,164 & 2,835 & 0,099 & 2,979 & 2,798 \\
\hline & 280 & 0,339 & 0,18 & 2,727 & 0,1 & 3,019 & 2,865 \\
\hline & 300 & 0,317 & 0,17 & 2,965 & 0,089 & 2,97 & 2,916 \\
\hline
\end{tabular}


L9 lentelè. IX varianto dinaminiai rodikliai

Table L9. IX version of dynamic indicators

\begin{tabular}{|c|c|c|c|c|c|c|c|}
\hline \multirow{15}{*}{ 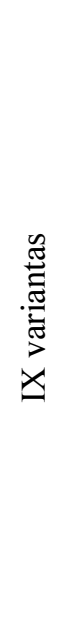 } & $v, \mathrm{~km} / \mathrm{h}$ & $K_{d v a}$ & $K_{d h a}$ & $K_{s}$ & $K_{d v c}$ & $W_{v}$ & $W_{h}$ \\
\hline & 40 & 0,068 & 0,067 & 5 & 0,031 & 1,849 & 1,495 \\
\hline & 60 & 0,146 & 0,1 & 5 & 0,051 & 2,269 & 1,763 \\
\hline & 80 & 0,186 & 0,081 & 5 & 0,042 & 2,243 & 1,874 \\
\hline & 100 & 0,192 & 0,098 & 5 & 0,048 & 2,311 & 1,99 \\
\hline & 120 & 0,205 & 0,103 & 5 & 0,052 & 2,449 & 2,148 \\
\hline & 140 & 0,225 & 0,122 & 4,265 & 0,063 & 2,549 & 2,314 \\
\hline & 160 & 0,271 & 0,157 & 3,406 & 0,078 & 2,6 & 2,468 \\
\hline & 180 & 0,293 & 0,18 & 3,191 & 0,075 & 2,587 & 2,612 \\
\hline & 200 & 0,328 & 0,191 & 3,08 & 0,088 & 2,78 & 2,689 \\
\hline & 220 & 0,358 & 0,195 & 2,815 & 0,075 & 2,895 & 2,717 \\
\hline & 240 & 0,37 & 0,197 & 2,759 & 0,087 & 2,907 & 2,737 \\
\hline & 260 & 0,37 & 0,193 & 2,749 & 0,1 & 2,99 & 2,812 \\
\hline & 280 & 0,346 & 0,202 & 2,603 & 0,103 & 3,026 & 2,838 \\
\hline & 300 & 0,319 & 0,221 & 2,42 & 0,09 & 2,974 & 2,868 \\
\hline
\end{tabular}

L10 lentelè. $X$ varianto dinaminiai rodikliai

Table L10. X version of dynamic indicators

\begin{tabular}{|c|c|c|c|c|c|c|c|}
\hline \multirow{15}{*}{ 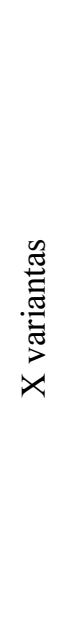 } & $v, \mathrm{~km} / \mathrm{h}$ & $K_{d v a}$ & $K_{d h a}$ & $K_{s}$ & $K_{d v c}$ & $W_{v}$ & $W_{h}$ \\
\hline & 40 & 0,067 & 0,065 & 5 & 0,031 & 1,835 & 1,501 \\
\hline & 60 & 0,13 & 0,057 & 5 & 0,052 & 2,242 & 1,672 \\
\hline & 80 & 0,157 & 0,065 & 5 & 0,04 & 2,203 & 1,745 \\
\hline & 100 & 0,176 & 0,063 & 5 & 0,046 & 2,286 & 1,9 \\
\hline & 120 & 0,192 & 0,086 & 5 & 0,05 & 2,429 & 2,051 \\
\hline & 140 & 0,22 & 0,104 & 5 & 0,062 & 2,537 & 2,215 \\
\hline & 160 & 0,267 & 0,108 & 4,986 & 0,076 & 2,587 & 2,335 \\
\hline & 180 & 0,301 & 0,11 & 5 & 0,073 & 2,577 & 2,49 \\
\hline & 200 & 0,345 & 0,113 & 5 & 0,085 & 2,774 & 2,585 \\
\hline & 220 & 0,368 & 0,119 & 4,389 & 0,074 & 2,883 & 2,627 \\
\hline & 240 & 0,369 & 0,134 & 3,927 & 0,086 & 2,895 & 2,713 \\
\hline & 260 & 0,363 & 0,148 & 2,686 & 0,099 & 2,979 & 2,76 \\
\hline & 280 & 0,336 & 0,157 & 2,752 & 0,101 & 3,008 & 2,826 \\
\hline & 300 & 0,315 & 0,169 & 3,225 & 0,088 & 2,956 & 2,88 \\
\hline
\end{tabular}


Stasys DAILYDKA

KELEIVIU VEŽIMO GELEŽINKELIU

PRIEMONIŲ PARINKIMO TYRIMAS

Daktaro disertacija

Technologijos mokslai, transporto inžinerija (03T)

A STUDY ON THE OPTIONS OF MEANS

FOR RAILWAY PASSENGER TRANSPORTATION

Doctoral Dissertation

Technological Sciences,

Transport Engineering (03T)

201104 20. 13,75 sp. I. Tiražas 20 egz.

Vilniaus Gedimino technikos universiteto

leidykla "Technika",

Saulètekio al. 11, 10223 Vilnius,

http://leidykla.vgtu.lt

Spausdino UAB "Ciklonas"

J. Jasinskio g. 15, 01111 Vilnius 